Manual of

Vertebrates

of Ontario

C. W.Nash. 


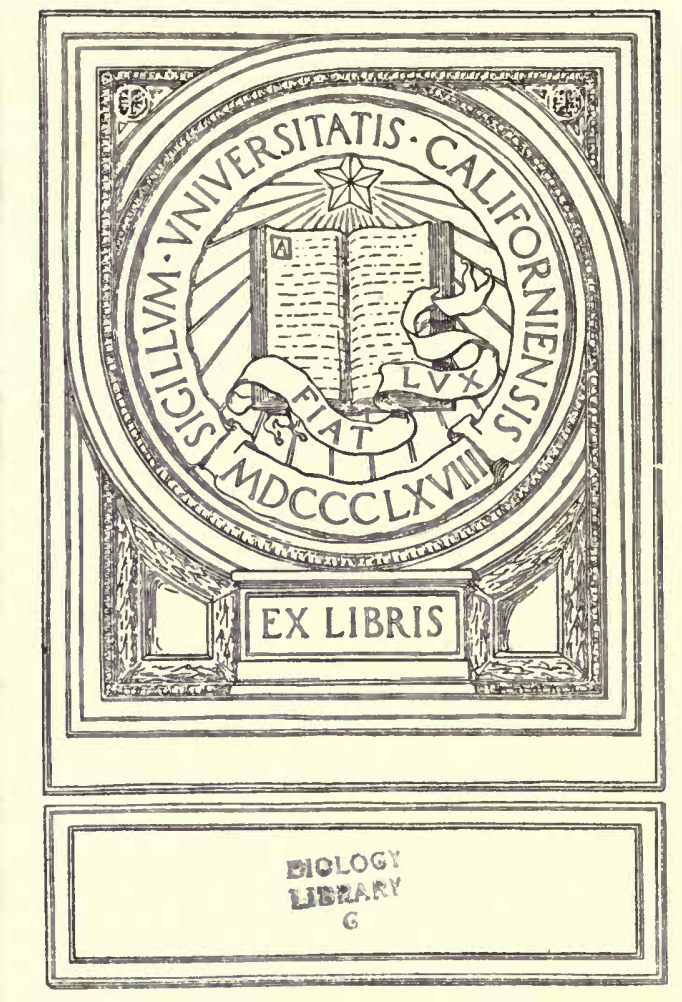








\title{
Vertebrates of Ontario
}

\author{
BY C. W. NASH
}

DEPARTMENT OF EDUCATION TORONTO

PRINTED BY ORDER OF

THE LEGISLATIVE ASSEMBLY OF ONTARIO.

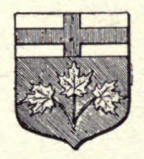


To the Honorable R. A. PYNE, M.D.,

Minister of Education,

Ontario :

I have the honor to present to you the "Manual of the Vertebrates of Ontario," produced under your authority and instructions by Mr. C. IV. Nash of Toronto.

This work has been issued in three separate sections, viz., "Birds of Ontario," "The Batrachians, Reptiles and Mammals of Ontario," and "Fishes of Ontario." To these sections has now been added a glossary and index to the whole.

The demand for each of these sections has been very great and the issue has been much appreciated, particularly by those engaged in educational work throughout the Province.

There is reason to believe that the presentation of this work will sreatly facilitate the study of animal life on the part of our people and especially of the young, whether they are pursuing systematic studies in natural history or are merely desirous of acquiring casual information on the subject.

The economic importance of knowledge concerning all forms of life is especially valuable in this Province where the great bulk of our wealth is drawn direct from the hands of nature. Unfortunately too little attention has been paid to this subject in the past, with the result that many of our most valuable forms of life are threatened with extermination.

This is particularly the case with our fish, many species of which have entirely disappeared from our waters, while others formerly so abundant as to have been within the reach of every person are now luxuries only obtainable by the rich.

Our lakes, with the application of scientific methods, could undoubtedly be made to produce an. unfailing supply of cheap and wholesome food. This, however, will only be done when those engaged in the fisheries have a better knowledge of the habits of the fish they capture and the general public are more fully informed of the value of this important national asset.

I have the honor to be, Sir,

Yours respectfully,

David Boyle,

Superintendent Provincial Museum.

Toronto, Nov. $25^{\text {th, }}$ I908. 


\section{PREFACE.}

In this work I have endeavoured to include all the vertebrates which have been found within the boundaries of the Province of Ontario.

\section{Fishes.}

The classification and sequence of groups adopted for the Fishes is that of Jordan and Evermann, to whom I am also chiefly indebted for the technical descriptions.

In the description of species the expressions "head 4 " or "depth 4 " mean that the length of the head in one case, or the greatest depth of the body in the other, is contained 4 times in the length of the fish measured from the tip of the snout to the end of the last caudal vertebra, the caudal fin being not included. The size of the eye and the length of snout and other head parts are compared with the length of the side of the head, unless otherwise stated; thus "eye 5" means that the horizontal diameter of the eye is I-5 the length of the head, "scales 5-64-7" means that there are 5 rows of scales between the base of the dorsal fin and the lateral line (the scale in the lateral line excluded), 6.7 oblique transverse series crossing the lateral line and 7 horizontal series between the lateral line and the base of the anal or the vent.

The fin formula are shortened as much as possible; thus "D. Io," "D. IV, 9," or "D. VIII-I3" means that in the first case the fish has a single dorsal fin of Io soft or articulated rays; in the second case a single dorsal fin of 4 spines and 9 soft rays; and the last indicates a fish with two dorsal fins, the first composed of 8 spines and the second of 13 rays.

Spines are always indicated in roman letters and rays in arabic letters.

The measurements given are intended to apply to the average of mature fishes. Young fishes usually have the depth less, the head and eye larger and the mouth smaller in proportion than adult examples of the same species.

The coloration and marking of fishes is extremely variable, no two individuals being exactly alike; and not only so, but each individual changes its color from time to time in accordance with its surroundings.

Consequently this character cannot be relied on in distinguishing a species, there being but very few, if any, which show in all stages the same coloration and markings. 
All color descriptions as given herein are intended to apply to the normal adult in its highest development as found in the waters to which it is best adapted.

\section{Batrachians and Reptiles.}

In the arrangement and classification of these animals I have followed the works of Prof. E. D. Cope.

The Batrachians and Reptiles of Ontario have as yet been but little studied, and but few collections have been made. It is probable that when more attention is given to them many North American species now known to occur in the States immediately adjoining us may be found generally distributed through the Province and that in the North some new forms may be discovered.

\section{BiRds.}

In this section the elassification and nomenclature adopted is that of the check list of the American Ornithologists' Union.

\section{MAMMALS.}

In the arrangement of the Mammals I have followed the system adopted by Dr. Jordan.

$$
\text { C. W. NASII. }
$$

Lee Avenue, Toronto.

November $25^{\text {th }}$, 1908 . 


\section{CHECK LIST}

\section{OF THE \\ FISHES OF ONTARIO.}

\section{PISCES (The Fishes).}

The Fishes may be defined as cold-blooded vertebrates, 'aduptêl for life in the water, breathing by means of gills attacned to licily ar cartilaginous gill arches; having the skull well developed and witn à lower jaw; with limbs present and developed as fins, or rarely wanting through atrophy; with shoulder girdle present, furcula shaped, curved forward and with the sides connected below; with pelvic bones present; having the exoskeleton developed as scales or bony plates, or horny appendages, sometimes obsolete, and with the median line of body with one or more fins composed of cartilaginous rays connected by membrane.

The Lampreys differ so widely from the true fishes, having no jaws, no limbs and no trace of the bones to which limbs should be hung that they are properly excluded from consideration as fishes. I have, however, included them here, as they are popularly believed to be fish and are of economic importance to our fishery interests from the fact that they destroy vast numbers of valuable food fish. 


\section{Class MARSIPOBRANCHII. (The Lampreys.)}

Skeleton cartilaginous; the skull imperfectly developed, not separate from the vertebral column. No true jaws, no limbs, no shoulder girdle, no pelvic elements, no ribs. Gills in the form of fixed sacs, without branchial arches, six or more in number on each side. Nostril single median. Mouth sub-inferior, suctorial, more or less circular. Heart without arterial bulb. Alimentary canal straight, simple, without cæcal appendages, pancreas, or spleen. Vertical fins with feeble rays, usually continuous round the tail. Naked, eel-shaped animals inhabiting cool waters. They undergo a metamorphosis, the young being often quite unlike the adult.

\section{Order HYPEROARTII. (The Lampreys.)}

Nasal duct a blind sac, not penetrating the palate.

\section{Family PETROMYZONIDÆ. (The Lampreys.)}

Bćdy él-shaped, subcylindrical anteriorly, compressed behind; mouth nearly circular, armed with horny teeth which rest on papillæ; gill openirg's seyer, arranged in a row along the side of the "chest" ; lips present, usually fringed; nostril on top of head, just in front of eyes; dorsal fin more or less deeply divided by a notch; the posterior part commonly continuous with the anal around the tail; intestines with a spiral valve; eggs small.

The Lampreys undergo a metamorphosis, the larvæ of all species being toothless and having the eyes rudimentary.

They attach themselves to fishes and feed by scraping off the flesh with their rasp-like teeth.

\section{Genus ICTHYOMYZON.}

Lampreys with the supraoral lamina armed with two or three separate teeth, pointed and close together, not forming a crescent-shaped plate; anterior lingual tooth divided by a median groove. The dorsal fin notched but not separated into two portions. 
(1) Silver Lamprey. Lamper Eel.

(Icthyomyzon concolor.)

Body rather stout, compressed posteriorly. The head is broad and the buccal disk large, with its edges not conspicuously fringed. The tooth on the front of the tongue is divided into two parts by a median groove, and the dorsal fin is continuous but deeply notched. The maxillary tooth is bicuspid; the teeth on the disk are in about four series and all small. The tooth-bearing bone of the lower part of the mouth has seven cusps. There are fifty-one muscular impressions from gills to vent.

Colour bluish silvery, sometimes with blackish mottlings. Above each gill opening there is a small bluish blotch. Length about twelve inches.

The Silver Lamprey is abundant in the Great Lakes, usually in deep water, but it runs up the small streams to spawn in the spring. It is a most destructive parasite on the large commercial fishes, fixing itself to their bodies by means of its suctorial disk and causing deep ulcerated wounds at the point of attachment, which very frequently result in death.

When spawning they form nests in the bed of the stream among cobble stones and pebbles; in these the eggs are deposited, after which the parent fish all die. After emerging from the eggs the larvæ burrow in the mud or sand near the margin of the stream and there remain in the larval condition, blind and toothless for a long period, sometimes until they have attained a length of eight inches.

\section{Genus LAMPETRA.}

Dorsal fin either notched or divided into two parts, the posterior part continuous with the anal around the tail; supraoral lamina broad, crescentic, with a large obtuse cusp at each end and sometimes a minute median cusp; lingual teeth small, with a crescentic toothed edge, the median denticle enlarged; buccal disk small, with few teeth which are never tricuspid.

The genus Lampetra is best distinguished from Petromyzon by the structure of its so-called maxillary tooth, which has the form of a crescent shaped plate with terminal cusps and sometimes an additional median cusp. In Petromyzon this bony plate is short and contains two or three teeth which are very closely placed. 


\section{(2) Brook Lamprey.}

(Lampetra wilderi.)

The high dorsal fin is divided into two parts by a deep notch. Several of the teeth on the side of the buccal disk are bicuspid and the rest simple. The mandibulary plate is nearly straight and has eight or ten cusps of nearly equal size. There are sixty-seven muscular impressions from gills to vent. In the spring a prominent anal papilla is present. The head is larger than the space occupied by the gill openings. Eyes large. Mouth moderately small. Lips conspicuously fringed with papillæ. The teeth change considerably with age; young specimens have no median cusp on the maxillary plate.

Colour, bluish black above; lower parts silvery. Length about eight inches.

This Lamprey ranges through the Great Lakes region, ascending small streams in the spring to spawn. It clings to stones and clods of earth while depositing its ova, and is believed by many persons to die after spawning.

Like the rest of the family, it is parasitic on other fish.

I am not positive as to the occurrence of this species in our waters, though I have often taken a small Lamprey in the northern and western streams of Ontario and in the rivers of Manitoba which I believe to be the Brook Lamprey.

\section{Class PISCES. (The Fishes.)}

The Fishes may be defined as cold-blooded vertebrates adapted for life in the water, breathing by means of gills which are attached to bony or cartilaginous gill arches; the gills persistent throughout life; having the skull well developed and provided with a lower jaw; the limbs present and developed as fins, rarely wanting through atrophy; shoulder girdle present, furcula shaped, curved forward below; pelvic bones present; exoskeleton developed as scales, bony plates, or horny appendages or sometimes entirely wanting, and with the median line of body with one or more fins composed of cartilaginous rays connected by membrane.

\section{Subclass TELEOSTOMI. (True Fishes.)}

Skeleton usually bony, sometimes cartilaginous. Skull with sutures; membrane bones (opercle, preopercle, etc.) present; gill openings a single slit on each side; gills with their outer edges free, their bases attached to bony arches, normally four pairs of these, the fifth pair being typically modified into tooth-bearing lower pharyngeals; median and paired fins developed, the latter with distinct rays. Ova small. Heart developed, divided into an auricle, ventricle and arterial bulb. Lungs imperfectly developed or modified to form a swim bladder or entirely absent. 
Under this head are now included the Ganoids and the Teleosts. The former group is chiefly composed of extinct forms. While many of its representatives are extremely dissimilar to the bony fishes, there is a gradual series of transitions, and between the Cycloganoidea of the Ganoids and the Clupeoids and others of the true Teleosts, the resemblance is much greater than that between the Cycloganoidea and many other Ganoids. The Ganoids are in fact the most generalized of the true fishes, those nearest the stock from which the Teleosts on the one hand and the Dipnoi, on the other, have sprung.

\section{Series GANOIDEI. (Ganoid Fishes.)}

The name Ganoidei was first used by Agassiz for those fishes which are armed with bony plates, instead of regular cycloid or ctenoid scales. Later the group has been restricted to those fishes thought to show more or less reptilian or batrachian affinities, and especially affinities with the mailed fishes of the Devonian and Carboniferous ages. The group is a heterogeneous one and one scarcely susceptible of definition. In some of the Ganoids the air bladder still retains its original function, a lung. The existence of the solid optic chiasma, the presence of several valves in the arterial bulb, and of a more or less developed spiral valve in the intestine, distinguish the living Ganoids from all Teleosts.

\section{Order SELACHOSTOMI. (Paddlefishes.)}

Notochord persistent, the division into vertebræ imperfect Mesocoracoid developed; no symplectic bone; premaxillary forming border of mouth; no suboperculum, preoperculum, nor interoperculum; mesopterygium distinct; basihyals and superior ceratohyal not ossified; interclavicles present; maxillaries obsolete; branchihyals cartilaginous.

\section{Famly POLYODONTIDAe. (Padilefishes.)}

Body fusiform, little compressed, covered with mostly smooth skin. Snout prolonged, expanded into a thin flat blade, the inner portion formed by the produced nasal bones, the outer portion with a reticulate bony framework, the whole somewhat flexible. Mouth broad terminal, but overhung by the spatulate snout, its border formed by the premaxillaries, the maxillaries being obsolete; jaws with many fine deciduous teeth; similar teeth on palatines; no tongue. Spiracles present. Operculum rudimentary, its skin produced behind into a long acute flap; no pseudobranchiæ, or opercular gill; gills four and one-half; gill rakers long, in a double series on each arch, the series divided by a broad membrane; gill 
membranes considerably connected but free from isthmus; a single broad branchiostegal. No barbels. Nostrils double at base of blade. Lateral line continuous, its lower margin with short branches. Dorsal fin well back, of soft rays only; anal similar, rather further back; tail heterocercal, the lower caudal lobe well developed, so that the fin is nearly equally forked; sides of the bent portion of the tail armed with small rhombic plates, caudal fin with fulcra. Pectorals moderate, placed low, ventrals abdominal, many rayed. Air bladder cellular, not bifid; pyloric cæca in the form of a short branching leaf-like organ; intestine with a spiral valve.

\section{Crenus POLYODON. (Paddlefishes.)}

Gill rakers exceedingly numerous, very slender; spatula broad. Caudal fulcra thirteen to twenty in number, of moderate size. Characters otherwise those of the family.

\section{(3) Paddlefish.}

(Polyodon spathula.)

The body of the Paddlefish is fusiform, with the snout much produced, spatulalike. Body scaleless, covered with smooth skin; mouth broad, terminal; teeth in jaws very numerous and fine; deciduous; spiracles with a minute barbel. The operculum is rudimentary, its flap of skin long, reaching almost or quite to the ventral fins; pseudorbanchiæ absent; gill arches five, the last rudimentary; gill rakers long and in a double series on each arch; gill membranes connected, free from the isthmus; nostrils double, situated at base of blade; a continuous lateral line from upper part of head along dorsal outline to tail; eye small; dorsal and anal fins far back, composed of soft rays, nearly opposite; tail heterocercal, well forked; sides of the bent portions of the tail armed with thombic plates. The pectoral fins are of moderate size and placed low; ventrals many rayed, abdominal.

This peculiar fish cannot well be confounded with any other species found in North American waters. It takes its name from its remarkable snout, which is produced into a long spatulalike process, covered with an intricate network and having very thin flexible edges.

In the Great Lakes the Paddlefish occurs but rarely, its centre of abundance being the larger streams of the Mississippi Valley; there are, however, two records of its capture in Ontario waters; one taken near Sarnia, now mounted and in the Fisheries Museum at Ottawa; the other, a fine specimen taken at Spanish River, Georgian Bay, in 1886, is also mounted and in the office of the Bureau of Fisheries, Toronto.

The flesh of this fish is coarse, but considered by some to be fairly good for table use. Of its habits little seems to be known, except that it is somewhat sluggish and prefers water with a muddy bottom. It grows to a length of five or six feet and specimens in the south have been taken weighing one hundred and fifty pounds. 


\section{Order CHONDROSTEI. (The Sturgeons.)}

Notochord persistent, the cartilaginous vertebræ imperfectly developen. A mesocoracoid. No symplectic bone. Maxillary present. No suboperculum or preoperculum. Interoperculum present. Mesopterygium distinct. Interclavicles present. Basihyals and superior ceratohyal not ossified. Branchihyals osseous. This group is composed of the single family Acipenseridæ, represented in our Province by one species.

\section{FAMILY ACIPENSERIDA.}

Body elongate, subcylindrical, armed with five rows of bony bucklers, each with a median carina which terminates in a spine, which sometimes becomes obsolete with age; a median dorsal series and a lateral and abdominal series on each side, the abdominal series sometimes deciduous; between these the skin is rough with small irregular plates. Head covered with bony plates joined by sutures; snout produced, depressed, conical or subspatulate. Mouth small, inferior, protractile, with thickened lips. No teeth. Four barbels in a transverse series on the lower side of the snout in front of the mouth. Eyes small; nostrils large, double, in front of eye. Gills, four; an accessory opercular gill; gill membranes united to the isthmus; no branchiostegals. Maxillary distinct from the premaxillary. Head covered with bony plates united by sutures. Fin rays slender, all articulated, vertical fins with fulcra. Pectorals placed low; ventrals many rayed, behind middle of body; dorsal placed posteriorly; anal somewhat behind it, similar; tail heterocercal, the lower caudal lobe developed, the upper lobe of the tail covered with rhomboid scales. Air bladder large, simple, connected with the œesophagus. Pseudobranchiæ small or obsolete. Stomach without blind sac; intestine with a spiral valve; pancreas divided into pyloric appendages.

Large fishes, feeding on small animals, sucked in through the tubelike mouth. Most of the species are migratory.

The changes with age are considerable, the snout in particular becomes much shorter and less acute and the roughness of the scales is greatly diminished; the ventral shields sometimes disappear altogether.

\section{Genus ACIPENSER.}

Snout subconical, more or less depressed below the level of the forehead. A small spiracle over the eye. Caudal peduncle moderately long, deeper than broad, the rows of bony bucklers distinct to the base of the caudal fin. Tail not produced into a filament, its tip surrounded by the caudal rays. Gill rakers small, narrowed or lanceolate. Pseudobranchiæ present. 


\section{(4) Lake Sturgeon. Rock Sturgeon.}

(Acipenser rubicundus.)

Dark olive above; sides paler or reddish often with irregular blackish spots. Body rather elongate. Snout slender and long in the young, becoming quite blunt with age. The shields are large, rough, with strongly hooked spines, becoming later comparatively smooth; ventral shields growing smaller with age and finally deciduous.

The fishermen make a distinction between the young and the old of this species, calling the former Rock Sturgeon and the older fish Lake Sturgeon. There is, however, but one Sturgeon in our waters; the difference in the size and shape of the snout and in the number and development of the spines between the immature fish and the adult is sometimes very great, hence the idea that two species are found.

The Lake Sturgeon is found in the Great Lakes and all the larger rivers falling into them, and is a food fish of considerable commercial importance, its flesh being used either fresh or dried and smoked. From its roe, the delicacy known as caviare is made. This fish attains a large size, specimens six feet in length and weighing one hundred pounds or more being not uncommon, though of late years they have decreased rapidly in both number and size.

The spawning season extends from the end of May to the beginning of July, during which period the fish run from the lakes up the rivers for a considerable distance for the purpose of depositing their ova.

\section{Order RHOMBOGANOIDEA. (The Gar Pikes.)}

Parietals in contact; pterotic, basis cranii, and anterior vertebræ simple; symplectics present. Mandible with coronoid, angular, articular and dentary bones; third superior pharyngeal small, lying on fourth, upper basihyal wanting; maxillary transversely divided. A cartilaginous mesocoracoid. Vertebræ opisthoccelian, that is, connected by ball and socket joints, the concavity in each vertebra being behind. Pectoral fins with mesopterygium and five other basal elements. Tail heterocercal. Air bladder lung-like, single, connecting with the dorsal side of the osophagus.

\section{Family Lepisosteid $Æ$. (Gar Pikes.)}

Body elongate, subcylindrical, covered with hard, rhombic ganoid scales or plates, which are imbricated in oblique series running downward and backward. Both jaws more or less elongate, spatulate or beak-like, the upper jaw projecting beyond the lower; premaxillary forming most of the margin of the upper jaw ; the maxillary transversely divided into several pieces. Lower jaw composed of as many pieces as in reptiles; coronoid present. Both jaws with an outer series of small teeth, followed by one 


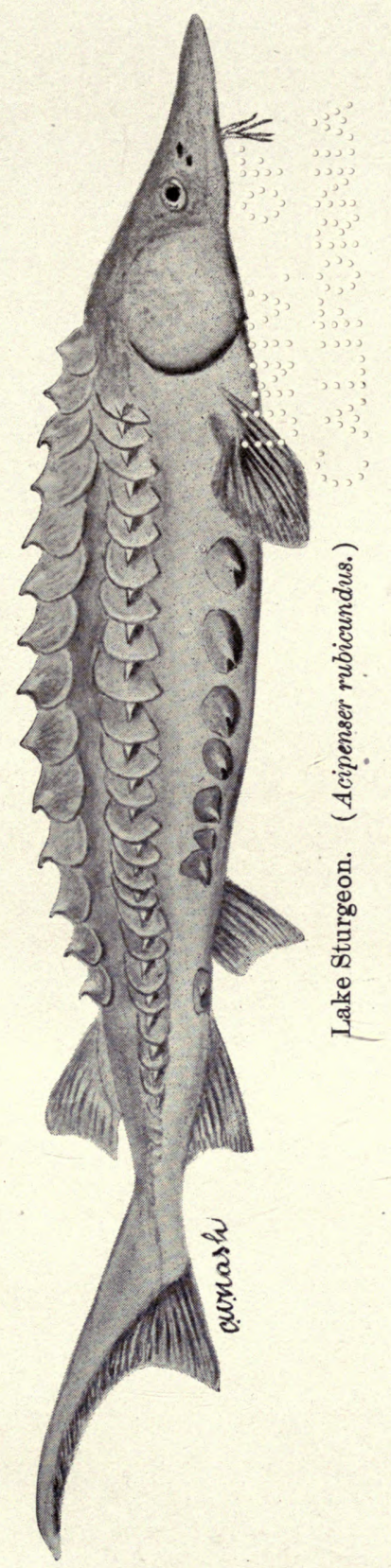




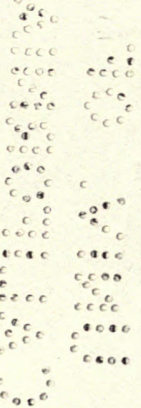


2 F. 


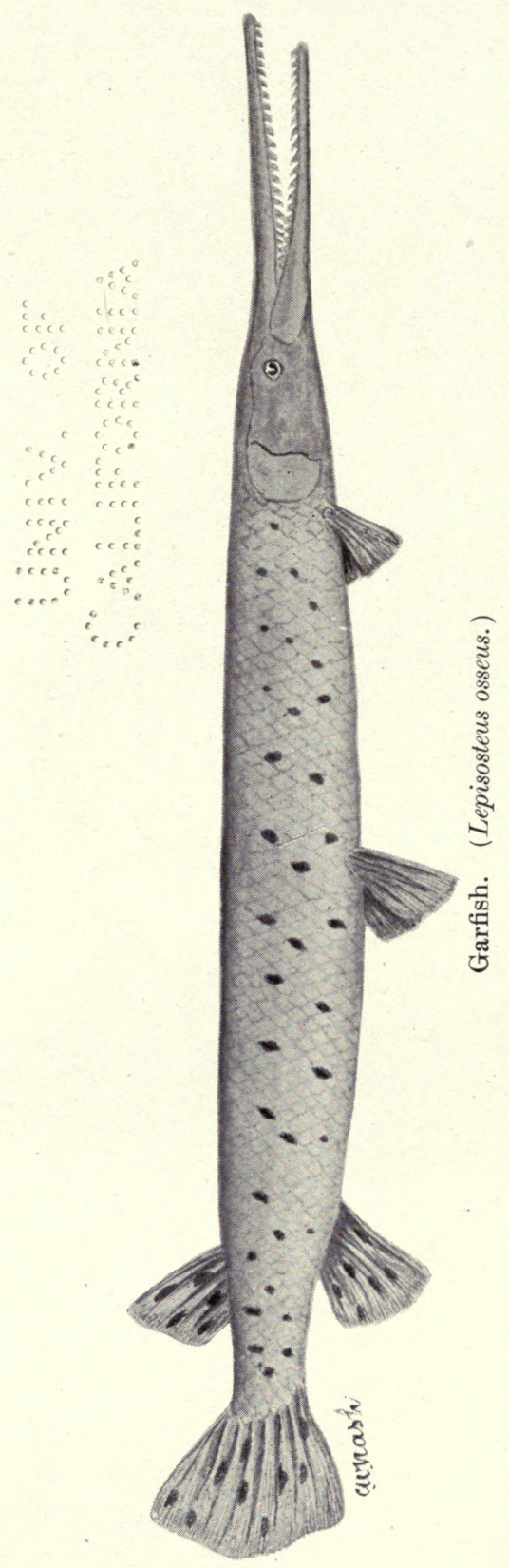


or two series of large teeth, besides which on the jaws vomer and palatines are a series of small, close-set, rasp-like teeth. Large teeth of the jaws conical in form, pointed and striate, placed at right angles to the jaw. Pharyngeals with rasp-like teeth. Tongue toothless, short, broad, emarginate, free at tip. External bones of skull very hard and rugose. Eyes small. Nostrils near the end of the upper jaw. An accessory gill on the inner side of the opercle. Pseudobranchiæ present. No spiracles. Gills, four, a slit behind the fourth. Branchiostegals, three. Gill membranes somewhat connected, free from the isthmus. Gill rakers very short. Air bladder cellular, lung-like, somewhat functional. Fins with fulcra; dorsal fin short, rather high, posterior, nearly opposite the anal, which is similar in form; tail heterocercal, in the young produced as a filament beyond the caudal fin; caudal convex; ventrals nearly midway between pectorals and anal; pectorals and ventrals moderate, few rayed. Stomach not cæcal; pyloric appendages numerous. Spiral valve of intestines rudimentary. Fresh water fishes of sluggish habits, but voracious and destructive to smaller fishes. The flesh is tough and rank, useless as food.

These fishes are of much interest from their relationship to extinct ganoid genera, many of which are placed in this family.

\section{Genus LePisosteus. (Gar Pries.)}

Upper jaw with an outer series of small, sharp, even teeth, then a series of large teeth, some of the anterior row being usually movable; next comes a series of fine teeth, in one row in front, becoming a band behind. In some species the inner row of these teeth contains larger ones; next the vomerine teeth, also in a long band, and posteriorly a palatine band. These bands on the roof of the mouth are frequently somewhat confluent or irregula1. In young specimens some of the palatine teeth are often enlarged, these sometimes forming regular series. Lower jaw with an outer series of small teeth, next a series of large teeth, next again a broad band of fine teeth on each side. Each of the large teeth fitting into a depression in the opposite jaw.

\section{Subgenus LEPISOSTEUS.}

(5) Gar-fish. Gar Pike. Bill-fish.

(Lepisosteus osseus.)

Body elongate, subcylindric. The jaws greatly produced, the upper being the longer. Teeth in the jaws rather fine, sharp and stiff; a single inner row of large teeth, and an outer row of small teeth on each side. The snout is more than twice as long as the rest of the head.

D., 7 to 8 ; A., 9 ; V., 6 ; P., io. Scales, 62 to 65 . 
Colour, greenish above; the sides silvery and the belly whitish; numerous round, dark spots on the sides, most distinct posteriorly and most conspicuous in the young, becoming obscure with age. Very young individuals have a blackish lateral band. Vertical fins with numerous round dark spots.

The Gar-fish is generally distributed from the upper St. Lawrence River through the Great Lakes and their tributaries to the head of Lake Huron. I have no records from Lake Superior; and it is probably most abundant in Lake Erie. It is said to attain a length of six feet and may possibly do so in southern waters, but I have never seen one taken in this Province which would exceed four feet. As a food fish it is valueless, its flesh being considered unwholesome. It spawns in late spring or early summer, running up the larger streams for that purpose.

\section{Subgenus CYLindRosteus.}

(6) Short-nosed Gar.

(Lepisosteus platostomus.)

Colour similar to L. osseus, but rather darker; from that species it may readily be distinguished by its shorter snout, which even in young specimens does not much exceed the rest of the head in length. Maximum length, about three feet.

D., 8 ; A., 8; V., 6. Scales on lateral line, about 56.

The Short-nosed Gar occurs sparingly in Lake Erie, its centre of abundance being in the Ohio and Mississippi Valleys.

Like the common Garfish, it is a voracious, destructive creature and of no value as a food fish.

\section{Order CYCLOGANOIDEA. (The Bowfins.)}

Parietals in contact. Pterotic, basis cranii and anterior vertebræ simple. Mandible with opercular and coronoid. Maxillary not transversely segmented, bordering the mouth. Third superior pharyngeal lying on enlarged fourth. Upper basihyal wanting. Vertebræ amphicœlian the anterior not modified. Pectoral fins with mesopterygium and eight other elements. Air bladder cellular and lung-like.

\section{Family AMIIDÆ. (The Bowfins.)}

Body oblong, compressed behind, terete anteriorly. Head subconical, anteriorly bluntish, slightly depressed, its superficial bones corrugated and very hard, scarcely covered by skin. Snout short, rounded; lateral margins of upper jaw formed by the maxillaries, which are divided 
by a longitudinal suture. Jaws nearly even in front; cleft of the mouth nearly horizontal, extending beyond the small eye; lower jaw broad, the rami well separated; between them a broad, bony plate, with radiating striæ, its posterior edge free; jaws each with an outer series of conical teeth, behind which in the lower is a band of rasp-like bands of small teeth on the vomer and pterygoids; palatines with a series of larger pointed teeth; premaxillaries not protractile; tongue thick, scarcely free at tip. Nostrils well separated, the anterior with a short barbel; suborbital very narrow; a bony plate covering the cheek, similar to the plates on the top of the head; operculum with a broad dermal border. Branchiostegals ten to twelve. No pseudobranchiæ nor opercular gill; no spiracle; gills, four, a slit behind the fourth; gill membranes not connected; free from the isthmus. Two peculiar, long, lanceolate obliquely striate appendages on each side of the isthmus, projecting backward and covered by the branchiostegal rays, the anterior wholly adnate to the isthmus, the posterior free behind. Isthmus scaleless. Gill rakers stoutish, very short. Scales of moderate size, rather firm, cycloid, with a membranous border. Lateral line present. Dorsal fin long and low, nearly uniform, the posterior rays not much higher than the others; its insertion in front of the middle line of the body, opposite the end of the pectoral. Tail somewhat heterocercal (more so in the young), convex behind, no-fulcra. Anal few, short and low. Pectoral and ventral fins short and rounded, the ventrals nearer anal than pectorals. Vertebræ amphicœlian or double concave, as usual among fishes, none of them specially modified. Abdominal and caudal parts of the vertebral column subequal. Air bladder cellular, bifid in front, lung-like, connected by a glottis with the pharynx and capable of assisting in respiration. Stomach with a blind sac; no pyloric cæca. No closed oviduct. Intestine with a rudimentary spiral valve.

Only one species of this family is known-among living fishes, but several fossil genera are commonly referred to it.

\section{Genus Amia. (Bowfins.)}

Body oblong, compressed behind, terete anteriorly; head subconical, anteriorly bluntish, slightly depressed, its superficial bones corrugated and very hard, scarcely covered by skin; snout short, rounded; lateral margins of upper jaw fermed by the maxillaries, which are divided by a longitudinal suture; jaws nearly even in front; cleft of the mouth nearly horizontal, extending beyond the small eye; lower jaw broad, U-shaped, the rami well separated; between them a broad, bony plate, with radiating strix, its posterior edge free; jaws each with an outer series of conical teeth, behind which in the lower is a band of rasp-like teeth; bands of small teeth on the vomer and pterygoids; palatines with a series of larger, pointed teeth; premaxillaries not protractile; tongue thick, scarcely free at tip; nostrils well separated, the anterior with a short barbel; suborbital very 
narrow; a bony plate covering the cheek, similar to the plates on the top of the head; operculum with a broad dermal border; branchiostegals ten to twelve; no pseudobranchiæ or opercular gill; no spiracle; gills four, a slit behind the fourth; gill membranes not connected, free from the isthmus; two peculiar long lanceolate, olbiquely striate appendages on each side of the isthmus, projecting backward and covered by the branchiostegal rays, the anterior wholly adnate to the isthmus, the posterior free behind; isthmus scaleless; gill rakers stoutish, very short; scales of moderate size, rather firm, cycloid, with a membranous border; lateral line present; dorsal fin long and low, nearly uniform; the posterior rays not much higher than the others; tail somewhat heterocercal (more so in the young), convex behind; no fulcrums; anal fin short and low; pectoral and ventral fins short and rounded, the ventrals nearer anal than pectorals; vertebræ amphicolian or double concave, as usual among fishes, none of them specially modified; abdominal and caudal parts of the vertebral column subequal; air bladder cellular, bifid in front, lung-like, connected by a glottis with the pharynx, and capable of assisting in respiration, stomach with a blind sac; no pyloric caca; no closed oviduct; intestine with a rudimentary spiral valve.

\section{(7) Dogfish. Bowfin. Mudfish.}

(Amia calva.)

Dark olive or blackish above, paler or sometimes bright green below, sides with traces of dark greenish reticulations; lower jaw and gular plate often with round blackish spots; fins mostly dark, somewhat mottled. Male with a round black spot at base of caudal fin above, this is surrounded by an orange or yellow border; in the female this is very faint, or more often wanting.

Lateral line nearly median, directed slightly upward at each end. Scales on lateral line, about sixty-five.

D., 50 ; A., io to I $2 ; \mathrm{V} ., 7$.

The female Dogfish is larger than the male, sometimes reaching a length of twenty-four inches, while the male rarely exceeds eighteen.

This fish is found generally distributed in sluggish $\cdots$ weedy waters from the upper St. Lawrence to the head of Lake Huron. I have no records for Lake Superior. It is one of the most voracious of our fishes, feeding upon all forms of small fry and insects, and where abundant is very destructive to the more valuable forms of fish life. Its flesh is said to be soft, nauseous, and quite uneatable.

In May and June the Dogfish resort to weedy bays and marshes, where they spawn, the parent fish remaining with the eggs until they are hatched, and afterwards protecting the young for some time. 


\section{Series TELEOSTEI. (The Bony Fishes.)}

This group comprises the majority of existing fishes. It is apparently descended from the Ganoid type. As a whole, the Teleostei differ from the Ganoids in the more perfectly ossified skeleton, the less heterocercal tail, the degradation of the air bladder and the arterial bulb, and in the simplicity of the optic chiasma.

The Teleostei are divisible into two great groups with rather illdefined boundaries, the Physostomi, or soft-rayed fishes, and the Physoclysti, or spiny-rayed. The members of the former group have throughout life a slender duct, by which the air bladder is joined to the alimentary canal. In most cases the fin rays are soft, the ventral fins abdominal, the pectoral fins placed low, and the scales cycloid. Although the typical Physostomi differ in many ways from the more specialized Physoclysti, yet as we approach the junction of the two groups the subordinate differences disappear, leaving finally the presence of the air duct in Physostomi as the only differential character.

\section{Subclass OSTARIOPHYSI.}

This group is characterized chiefly by the modification of the anterior vertebræ. These are coössified and have some of their lateral and superior elements detached and modified to form a chain of small bones, the Weberian ossicles, which connect the air bladder with the ear.

\section{Order NEMATOGNATHI. (Catfishes.)}

This order contains several families, which agree in having the sub. opercle wanting, the anterior vertebræ coalesced, and the maxillary reduced to the bony core of a long barbel. None of the order have scales.

\section{Family SILURID $A$. (Catfishes.)}

Body more or less elongate, naked, or with bony plates. No true scales. Anterior part of head with two or more barbels; the base of the longest pair formed by the small or rudimentary maxillary. Margin of upper jaw formed by premaxillaries only. Suboperculum absent; operculum present. Dorsal fin usually present, short, above or in front of the ventrals. Usually an adipose fin behind dorsal. First ray of dorsal and pectorals usually developed as a stout spine. Lower pharyngeals separate. Air bladder usually present, large and connected with the organ of hearing by means of the auditory ossicles.

A vast family of more than one hundred genera and upwards of nine hundred species, mostly of the rivers and swamps of warm regions, especially of South America and Africa. A few species are marine. They are all very tenacious of life and most of them are excellent as food. 


\section{Genus ICTAluRUS. (Channel Catfish.)}

Body slender, elongate, compressed posteriorly; head slender, conical; superoccipital bone or process prolonged backward, its emarginated apex receiving the acuminate anterior point of the second interspinal, thus forming a continuous bony bridge from the head to the dorsal spine; mouth small, terminal, the upper jaw longer; teeth subulate, in a short band in each jaw; dorsal fin high, with one long spine and usually six rays; adipose fin over posterior part of anal; anal fin long, with twenty-five to thirtyfive rays; ventral fins each with one simple and seven branched rays; fins each with a stout spine, retrorse serrate within, and about nine rays; pectoral fins each with a stout spine, retrorse serrate within, and about nine rays; caudal fin elongate, deeply forked, the lobes pointed, the upper the longer. Colouration pale or silvery, usually with dark spots on the sides.

\section{(8) Channel Cat. Spotted Cat.}

(Ictalurus punctatus.)

Head rather small, narrow, convex above, so that the eye is little nearer the upper than the lower outline. Eye rather large (for a Catfish). Mouth small. Barbels long, the maxillary barbels reaching more or less beyond the gill opening. Spines long, the pectoral spines strongly serrated behind. Body rather long and slender. Colour light olivaceous or bluish above; sides silvery, nearly always marked with irregular small, dark, roundish spots; belly white; fins often with dark edgings.

D. I., 6; A., 24; V. I., 8.

It is extremely variable in colour and in number of fin rays, and has consequently been described under a number of different names.

The Channel Cat grows to a length of about three feet and a weight of twenty-five pounds or rather more, and is a most excellent table fish. It is not very common in our waters, but is taken most frequently in Lakes Erie and Ontario. Unlike most of the family, it seems to prefer pure, clear water and is partial to deep, flowing streams.

\section{Genus AMEIURUS. (Horned Pouts.)}

Body moderately elongated, robust anteriorly, the caudal peduncle much compressed; head large, wide, obtuse ; superoccipital extended backward, terminating in a more or less acute point, which is entirely separate from the second interspinal buckler; skin covering the bones thick; eyes rather small; mouth large, the upper jaw usually the longer; teeth in broad bands on the premaxillaries and mandibles; band of upper jaw convex in front, of equal breadth, and without backward prolongation at the angle; dorsal over the space between pectorals and ventrals, higher 


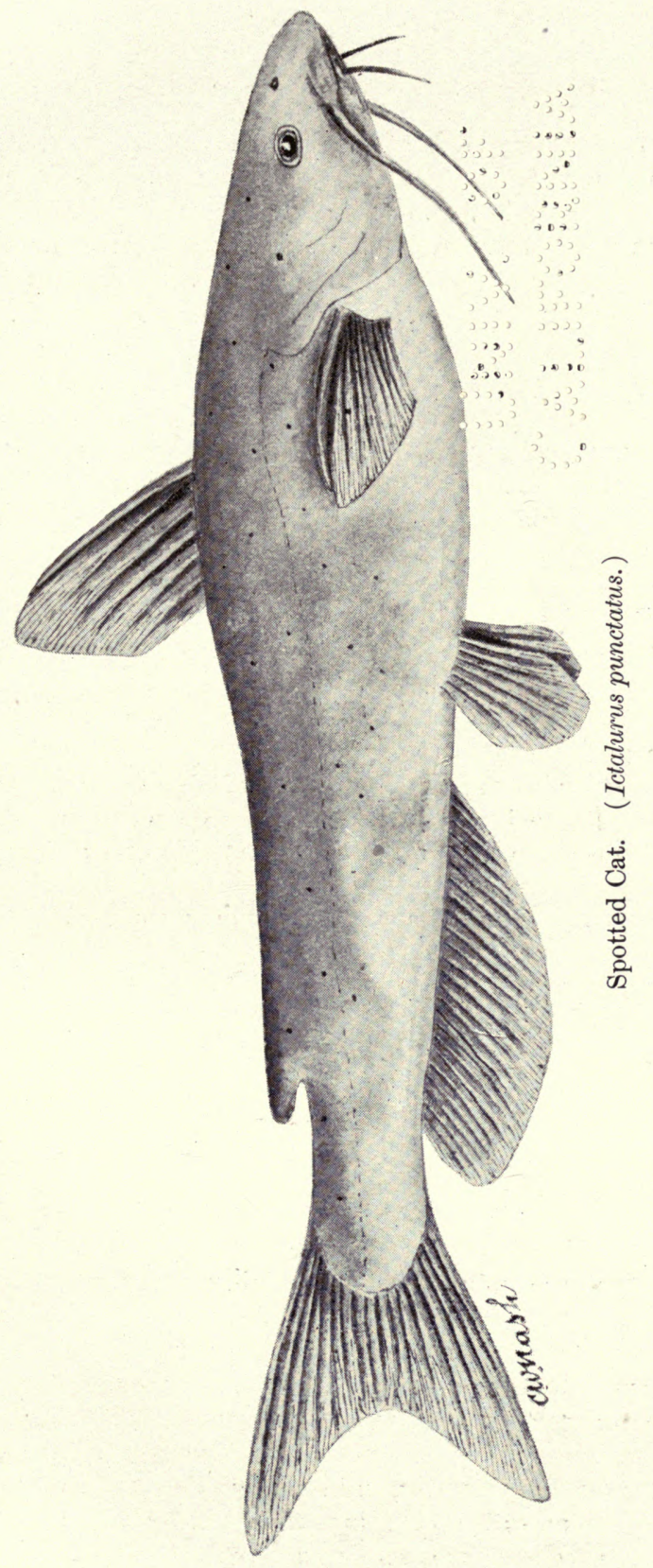




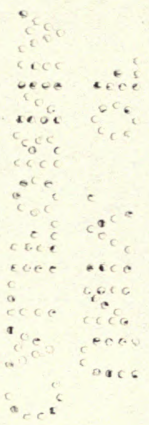


than long, with a sharp spine and about six branched rays; adipose fin short, inserted over the posterior half of the anal. Anal fin of varying length, with fifteen to thirty-five rays, the usual number being twenty or twenty-one. Caudal fin short, truncate in typical species, more or less forked in those species which approach the genus Ictalurus. Ventrals each with one simple and seven branched rays. Pectorals each with a stout spine, which is commonly retrorse serrate behind. Lateral line usually incomplete.

The species are variable and not easily distinguished. Those in which the caudal fin is forked make an approach to the genus Ictalurus. The lack of connection between the supraoccipital and the interspinal buckler is the only character by which these species can be separated from Ictalurus.

\section{Subgenus Haustok.}

\section{(9) Lake Catfish. Channel Cat.}

(Ameiurus lacustris.)

Head broad, much depressed; mouth wide; eye rather small. Body stout; dorsal base short, one-half the height of fin. Adipose fin well developed; caudal not deeply forked; pectoral spine as long as dorsal spine. Colour olivaceous slaty, growing darker with age; sides pale, no spots; anal dusky on edge; barbels black.

D. I., 5 to 6 ; A., $25 ;$ V. I., 8 .

This Catfish has a wide range, and is consequently variable. It is generally distributed throughout the Great Lakes and in deep rivers, but is more abundant in Lake Erie than any other of our waters.

As a food fish it is highly esteemed by people who have no prejudices against Catfish in general, though, like the rest of the tribe, its appearance is not prepossessing.

In the south specimens weighing over one hundred pounds are said to be taken, but with us the fish very rarely attains a greater weight than about thirty pounds.

Of its habits but very little is known. It is a bottom feeder and will take a great variety of baits. Night lines set in its haunts and baited with pieces of fish or small frogs are successfully used in taking it.

\section{Subgenus AMEIURUS.}

\section{(10) Yellow Catfish.}

(Ameiurus natalis.)

Head rather broad; mouth wide, with the upper jaw usually longer than the lower, sometimes equal. The dorsal profile gradually ascends from the snout to the dorsal spine. Eye moderate; maxillary barbel reach- 
ing end of head; humeral shield little developed; dorsal and pectoral spines strong, shorter than soft rays; height of dorsal equal to twice the length of its base; adipose fin long, opposite to and longer than anal; caudal rounded. Colour yellowish, more or less clouded with darker. Length about eighteen inches.

D. I., 6 ; A., 24 ; V. I., 8.

The Yellow Cat is found in Lakes Ontario, Erie and Huron. It is not a very well marked species and is in consequence generally confused with the other small Catfish. Its flesh is much esteemed by some peoplt, but as an angler's fish it is not highly prized.

Sluggish streams, weedy bays and deep water marshes are its favorite resorts, and in its habits it resembles the other members of the genus.

\section{(I I) Long-jawed Catfish.}

(Ameiurus vulgaris.)

Head longer than broad, rather narrow forward, mouth wide; barbels long; lower jaw more or less distinctly projecting. Eye very small. Adipose fin well developed. The pectoral spine is stout and about two-thirds as long as the fin. Caudal square; anal rounded. Length about eighteen inches. Colour dark reddish brown, varying to blackish. D. I., 6; A., I 8 to $20 ;$ V. I., 8 .

This species is found in most still weedy waters throughout the Pro vince, being most abundant from Lake Erie westward. Under favorable conditions it sometimes attains a weight of four pounds and is equally good as a food fish as the rest of its tribe, which it also resembles in its habits.

\section{(12) Common Catfish. Bullhead.}

(Ameiurus nebulosus.)

Head heavy, upper jaw usually distinctly longer than the lower. Barbels, eight; maxillary barbels as long as head; dorsal profile from tip of snout to dorsal fin straight and rather steep; mouth wide and terminal; teeth awl-shaped, in broad bands on the intermaxillaries and dentaries; dorsal situated in front of middle of body, short and high; adipose fin stout; anal large. Caudal square or slightly emarginate. Colour very variable, usually dark yellowish or olive, clouded with darker above, becoming yellowish or almost white below; sometimes entirely black.

D. I., 6 ; A., 20 to 22 ; V. I., 6.

This species reaches a maximum length of about eighteen inches and a weight of four pounds; the average of those taken in our waters is, however, much less. It is the common Catfish of the Province, occurring abundantly in all quiet streams, ponds and bays, especially in those having a mud bottom.

Early in June, when about to spawn, the Catfishes select a spot in quiet shallow water near aquatic weeds and there they make a nest. from 


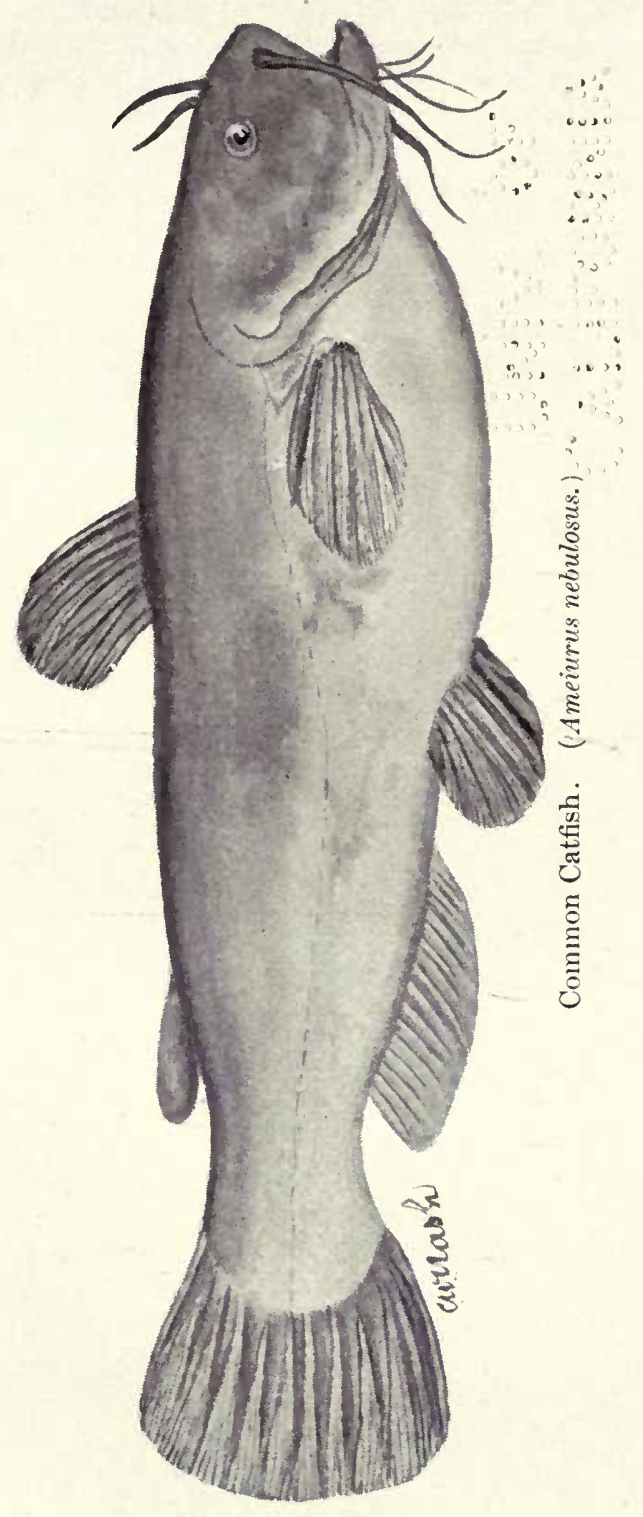




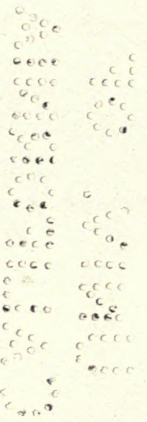


eight inches to one foot in diameter, by clearing out a slight iepression in the mud or sand. In this nest about two thousand eggs are deposited, over which the parents keep guard, the male being most assiduous in the work of protection. In about a week the eggs are hatched and the roung, which look very like little black tadpoles, follow the parent fish along the shores until nearly the middle of July, when they are left to shift for themselves; after this the fry soon scatter and disappear into deep weedy water. They grow rapidly, and under favorable circumstances are said to attain maturity in three years.

The Catfish is an omnivorous feeder, nothing in the shape of animal food being beneath its notice, nor is it particular where it obtains its food, for I have taken it at all depths from the surface of the water to the bottom, though its general habit is to grub about on the mud, seeking for what it may devour.

As an article of food this fish does not rank in the first class in the estimation of most people; there are others, however, who prefer it to any of the so-called "coarse fish," while to the small boy who goes fishing it is a source of endless delight and a joy forever.

\section{(13) Black Catfish.}

(Ameiurus melas.)

Body short, stout and deep. Head broad behind, rather contracted anteriorly; the dorsal profile straight and rather steep from tip of snout to dorsal fin; eye rather small; barbels longer than head. Caudal peduncle stout. Tail truncate; adipose fin well developed; teeth very fine, awlshaped and in broad bands. Rays of anal fin white, in marked contrast with the dark membranes. The dorsal spine strong and sharply pointed; anal fin short and deep.

D. I., 6 ; A., I7 to 19.

This is a small species, rarely exceeding ten inches in length. In colour it varies from yellowish brown to black above, becoming bluish white below.

I am not certain that this species should be included here, though it is recorded from the upper St. Lawrence and from the south shore of Lake Ontario, in New York State, and I believe that many years ago I took it in the County of Lincoln, Ontario. It will probably be found sparingly in Lake Erie, but its centre of abundance is south and west of this Province.

\section{Genus NOTURUS. (Stone Catfish.)}

Body moderately elongate, robust except in caudal part, which is much compressed; head flat and broad; mouth terminal broad; teeth in broad villiform bands on premaxillaries and dentaries; teeth of upper jaw prolonged backward into an elongate triangular extension; adipose fin adnate to the back; a poison gland at the base of the pectoral spine. 


\title{
(14) Stone Catfish.
}

\author{
(Noturus flavus.)
}

Body moderately elongate; head broad and flat; barbels short, longer barbel on chin not quite half as long as the head; nasal barbel when laid back reaches end of eye. The low adipose fin begins over the anal origin and continues into the caudal; in adult specimens it is deeply notched. Caudal fin rounded. Pectoral spine retrorse-serrate in front, roughish behind. Colour nearly uniform yellowish brown.

Length about twelve inches.

D. I., 6; A., I6; V., 9; P. I., 9.

This species appears to be generally distributed through the Lake Ontario and Erie waters, but is not abundant. It is an unpleasant fish to handle because of the painful wounds produced by its pectoral spines. There is a minute pore at the base of the pectoral spine which is the outlet of a noxious fluid secreted by a poison gland. When this poison is discharged into a wound it causes a very painful sore.

\section{Genus SCHILbEODES.}

Body moderately elongate, rounded anteriorly, compressed posteriorly ; head flat; skin very thick, concealing bones of head; superoccipital not joined to the head of the second interspinal; mouth large, anterior, the upper jaw somewhat the longer; awl-shaped teeth in broad bands in the jaws, the band in the upper jaw abruptly truncate at each end and not prolonged into a backward extension as in Noturus; branchiostegals nine; dorsal fin nearer to ventrals than to pectorals, with a short spine and seven rays; adipose fin long and low, adnate to the body and continuous with the caudal fin, the adipose membrane sometimes high and continuous, sometimes emarginate; caudal fin very obliquely truncated or rounded, its base also obliquely rounded; many rudimentary rays both above and below the caudal peduncle; anal fin short, with twelve to twenty-three rays; ventrals rounded; pectoral fins with a sharp spine of varying form; vent well in front of anal fin; lateral line complete. A poison gland opening by an orifice in the axil of the pectoral. Wounds caused by the pectoral spines are exceedingly painful.

\section{Subgenus SCHILBEODES.}

\section{(15) Tadpole Stone Cat. Mad Tom.}

(Schilbeodes gyrinus.)

Body short and stout, sloping rapidly downward from the dorsal origin to the tip of the snout. Head short, broad and depressed, its width nearly equal to its length; jaws nearly equal; snout short; eye small. The maxillary barbel reaches to the base of the pectoral; the outer mandibulary 
barbel is slightly longer. The nasal barbel is one-half as long as the head. Adipose fin low, beginning over the anal origin and is continuous with the caudal. The ventral origin is under the end of the dorsal base, the fin does not reach to anal origin. The caudal is rounded.

Colour brownish without blotches.

D. I., 6; A., I 3 to 15 ; P.I., 8.

This little Catfish rarely exceeds four or five inches in length. It frequents slow streams and weedy ponds and has the habit of hiding beneath stones and among water plants. As in Noturus, there is a poison gland at the base of the pectoral spine. It is said to occur in the region of the Lower Lakes, but as yet I have not found it.

\section{Order PLECTOSPONDYLI. (Carplike Fishes.)}

Soft-rayed or physostomous fishes, with the parietals broad, distinct; pterotic normal; symplectic present; opercular bones all present; mesocoracoid present; no interclavicles; the four anterior vertebræ much modified and joined together, provided with the Weberian apparatus or ossicula auditus. Branchiostegals few, usually three or four; shoulder girdle attached to the skull. This group consists entirely of fresh water fishes, and includes about eight families, to which belong the majority of all the fresh water fishes of the world. The essential character of the order lies in the modification of the anterior vertebrx, as in the Nematognathi, but without the character of the rudimenary subopercle and maxillary and the scaleless skin which distinguish the Catfishes.

\section{Suborder EVENTOGNATHI. (The Carps.)}

Plectospondylous fishes with the lower pharyngeals falciform, parallel with the gill arches; two upper pharyngeal bones; brain case produced between orbits; jaws without teeth; dorsal fin present; no adipose fin; ventrals abdominal. Gill openings restricted, the gill membranes attached to the isthmus. Streams and lakes of northern regions. Species very numerous.

\section{Family CATOSTOMIDAE. (The Suckers.)}

Body oblong or elongate, usually more or less compressed. Head more or less conical. Opercles normally developed. Nostrils double; no barbels; mouth large or small, usually protractile and with fleshy lips. Margin of upper jaw formed in the middle by the small premaxillaries, and on the side by the maxillaries; jaws toothless. Lower pharyngeal bones falciform, armed with a single row of numerous comb-like teeth. Branchiostegals three; gill membranes more or less united to the isthmus, restricting the gill openings to the sides; gills four, a slit behind the $3 \mathrm{~F}$. 
fourth; (pseudobranchiæ present. Scales cycloid, large or small. Lateral line decurved, sometimes wanting. Head naked; fins not scaly. Dorsal fin comparatively long (of ten to fifty rays), without true spine; anal fin short; caudal fin more or less forked; ventrals abdominal, with about ten rays; pectoral fins placed low, without spine; no adipose fin; belly not serrated. Alimentary canal long. Stomach simple; no pyloric cæca. Air bladder large, divided into two or three parts by transverse constrictions, not surrounded by a bony capsule.

\section{Genus ICTIOBUS. (Buffalo Fishes.)}

Body robust; head very large and strong. Eye moderate, anterior. Fontanelle large, well open. Opercular apparatus largely developed; the suboperculum broad; the operculum strongly furrowed. Mouth large for a sucker, terminal, protractile forward, or downward and forward. Mandible strong, oblique. Lips little developed; the upper narrow and smooth; the lower rather full on the sides, but reduced to a narrow rim in front. Jaws without cartilaginous sheath. Muciferous system of head well developed. Isthmus narrow. Pharyngeal bones rather weak; the teeth numerous, moderate or small; the lower ones gradually larger than the upper ones. Gill rakers long and slender above, becoming shorter downward. Scales large, thick, nearly equal over the body; lateral line well developed, slightly decurved anteriorly. Dorsal fin elongate; anterior rays somewhat elevated, their length about half that of the base of the fin; caudal not much forked; anal fin not much elevated; pectorals and ventrals moderate. Sexual differences slight.

This genus contains an uncertain number of species, very few of which have been yet well defined. They are large, coarse suckers, especially characteristic of the streams of the Mississippi Valley, and need much study.

\section{Subgenus ICTIOBUS.}

\section{(i6) Buffalo-fish. Sucker-mouthed Buffalo.}

(Ictiobus bubalus.)

Body considerably elevated and compressed above; the dorsal region subcarinate; belly thicker; axis of body above the ventrals, below the lateral line, and nearly twice as far from the back as from the belly. Head moderate, triangular in outline when viewed from the side. Mouth quite small; mandible about equal to eye. Dorsal fin elevated in front and rapidly declined, the highest ray reaching much beyond the middle of the fin, the seventh ray about half the length of the third or longest. Anal rays rapidly shortened behind; the middle rays much shorter than the first long ones. Caudal deeply lunate. Colour, pale, slightly dusky; fins scarcely dusky. D., 29; A., ro; V., ıо. Scales, 8, 39, 6. 



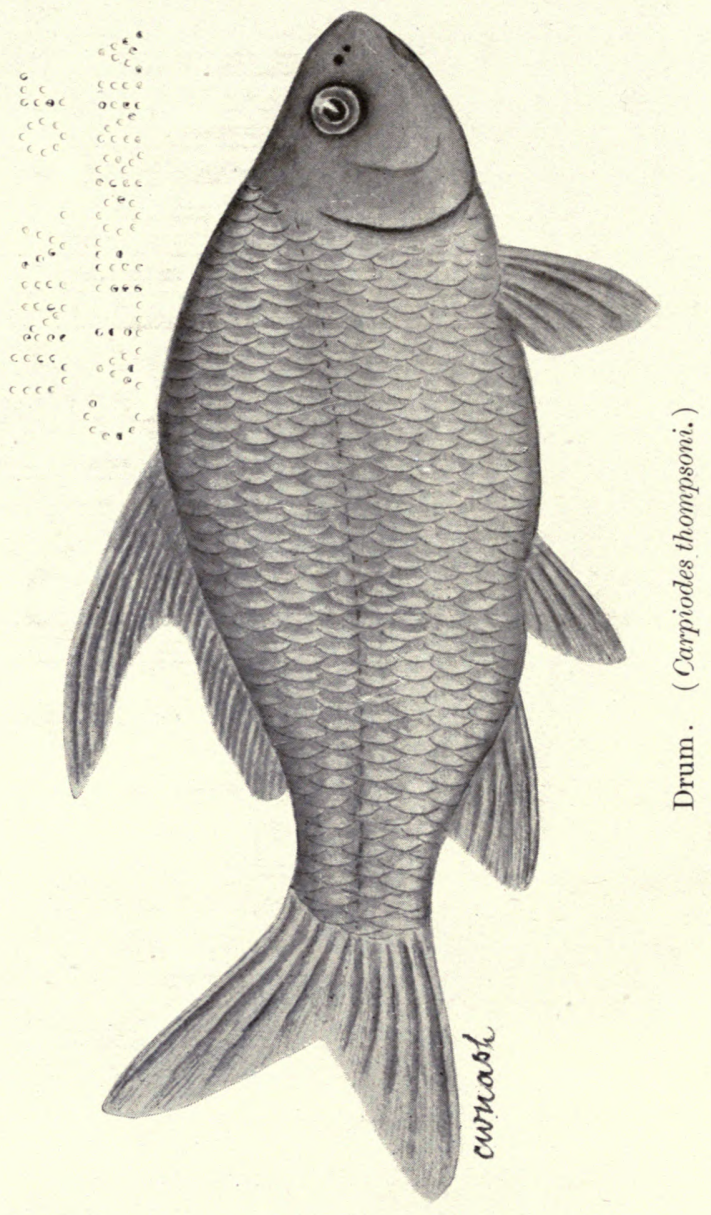


Southward and in the Mississippi basin this is the best known of all the Buffalo fishes. It reaches a length of three feet and a weight of thirtyfive pounds.

The only Ontario record I have is that of a specimen in the Fisheries Museum at Ottawa, said to have been taken in this Province.

\section{Genus CARPIOdes. (Carp Suckers.)}

Body oblong, the dorsal outline more or less arched; ventral outline nearly straight; depth from one-half to one-third of length; sides compressed; the back sharp edged; caudal peduncle short and deep; head short and deep, its upper surface rounded; eye moderate, median or anterior; suborbital bones well developed; fontanel present; mouth small, horizontal and inferior; mandible short; lips thin, the upper protractile, narrow, the lower narrow; lips freely plicate or nearly smooth; jaws without cartilaginous sheath; muciferous system moderately developed; opercular apparatus well developed, the subopercle broad; isthmus moderate; pharyngeal bones remarkably thin, laterally compressed, with a shallow furrow along the anterior margin on the inside, and another more central on the outline of the enlarged surfaces; teeth very small, compressed, nearly equally thin along the whole inner edge of the bone, forming a fine, comblike crest of minute serratures, their cutting edge rising above the inner margin into a prominent point; gill rakers slender and stiff above, becoming reduced downward; scales large, about equal over the body; lateral line well developed, nearly straight; dorsal fin long, nearly median, somewhat in advance of ventrals, falcate, its anterior rays elevated, often filamentous; caudal fin well forked, the lobes equal; anal fin comparatively long and low, few-rayed; ventrals rather short, usually with ten rays; pectorals short, placed low; air bladder with two chambers. Size medium or rather large.

\section{(17) Drum. Lake Carp.}

(Carpiodes thompsoni.)

Body short and stout, the back strongly arched. Head short, the snout acutely pointed; lips thin, white, meeting at a wide angle; tip of lower jaw much in advance of nostrils; eye small; dorsal about median, its rays considerably elevated, the longest two-thirds as long as base of fin. Scales rather closely inbricated, 8-39 to $4{ }^{\mathrm{I}-6}$.

D., 27 ; A., 7 ; V., ro.

This fish ranges from the upper St. Lawrence to Lake Huron, and is common in Lake Erie. It is not valued as a food fish, its flesh being coarse and not well flavored.

It attains a weight of five or six pounds. 


\section{Genus Castostomus. (Fine-Scaled Suckers.)}

Body elongate, fusiform, rounded, tapering anteriorly and posteriorly ; head long, with pointed snout; eye small, placed high; suborbital bones narrow; fontanel present, large; mouth rather large, inferior, upper lip thick, protractile, papillose, lower lip greatly developed, with a broad free margin, usually deeply incised behind, so that it forms two lobes, which are often more or less separated; mandible horizontal, short; opercles moderate; pharyngeal bones moderate, their teeth shortish, vertically compressed, rapidly diminishing in size upward; scales comparatively small; typically much smaller and crowded anteriorly; lateral line well developed, straightish; dorsal nearly median, with from nine to fourteen rays; anal fin short and high, with seven developed rays; ventrals inserted under the middle or posterior part of dorsal, with nine to ten rays; caudal fin forked, the lobes nearly equal. In males the fins are higher, and the anal is swollen and tuberculate in the spring. Air bladder with two chambers, the posterior large. Vertebra forty-five to forty-seven.

\section{Subgenus CATOSTOMUS.}

\section{(18) Northern Sucker. Long-nosed Sucker.}

(Catostomus catostomus.)

Body elongate, round and tapering. Head long and slender, depressed and flattened above, broad at the base, but tapering into a long snout which overhangs the large mouth; lips thick, coarsely tuberculate, the upper lip narrow, with two or three, sometimes four, rows of papillæ; lower lip deeply incised. Eye small; scales very small, much crowded anteriorly.

D., Io or II; A., 7 or 8 ; V., Iо.

Colour above greyish brown, becoming white below. Males in spring with the head profusely tuberculate and the side with a broad rosy band. In many specimens this band is persistent all through the season.

This Sucker has a very wide range, being found from the St. Lawrence River all through the Great Lake region to the extreme north, and is abundant in the streams about Hudson's Bay. It spawns in early spring.

As a food fish it is not highly esteemed. When fully grown it reaches a weight of four or five pounds.

\section{Subgenus DECACTyLUS.}

(i9) Common Sucker. White Sucker.

(Catostomus commersonii.)

Body moderately stout, heavy at the shoulders and tapering to the tail. Head conical, flattish above; snout rather prominent, scarcely over- 


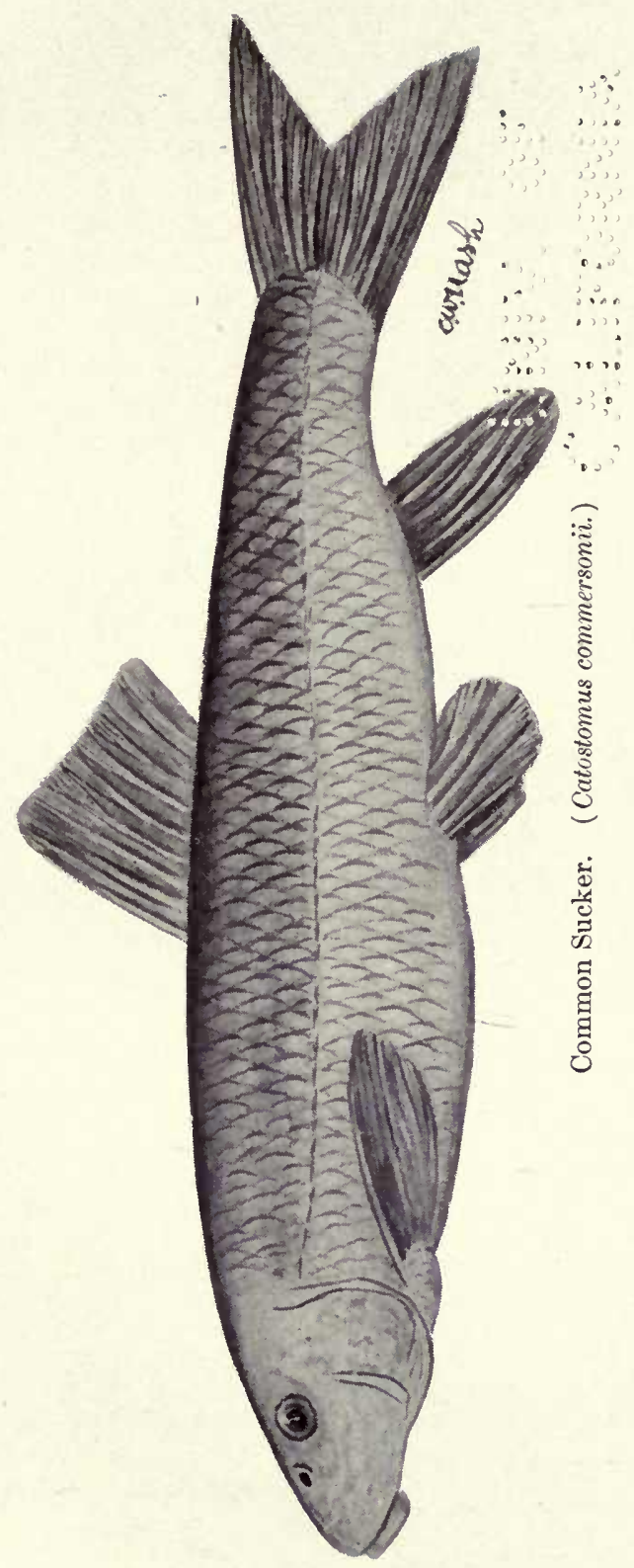




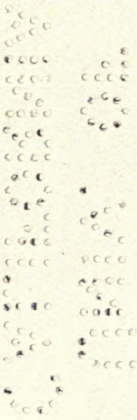


passing the mouth, which is rather large, with the lips papillose, the upper with two or three rows of papillæ. Scales small, crowded anteriorly, larger on the sides and below; dorsal fin situated in middle of length; ventral opposite dorsal; anal far back.

Scales, I0-64 to 70-9.

D., I2; A., 7 ; V., 9 .

Colour, brownish or olivaceous above, white below; the males in spring showing a rosy flush. The young more brownish, very much blotched and marked with blackish. A small race of this species occurs in streams which are blocked by dams or other impediments so as to prevent the fish ever running down to the lakes. These fish never grow to a greater length than about five or six inches, nor do they lose the dark markings of the young; yet in that condition they undoubtedly spawn, for the supply is always maintained.

This is the most abundant of all the Suckers in Ontario waters, and the most generally distributed. It is found in lakes, rivers and even in land-locked marshes and ponds. It spawns in early spring soon after the ice goes out, and then forces its way up the flooded streams and through the swiftest rapids to reach the spawning beds. At this time vast numbers are speared and netted by fish-hungry people in the rural districts, for at this season its flesh is eatable, though coarse and full of bones. Commercially it is of very little value, but as it affords food for Bass, Lake Trout, and all other predaceous and voraceous fishes, it is of considerable economic importance.

Its food consists largely of soft-bodied insects and the smaller crustaceans, and it will readily take worm bait.

The largest I have ever seen would weigh from three to four pounds, but they were exceptional: from one and a half to two being about the average size of the spring run of Suckers.

\section{Subgenus HYPENTELIUM.}

\section{(20) Hog Sucker. Stone Roller.}

\section{(Catostomus nigricans.)}

Body subterete; head flattened on top, the interorbital space concave and the frontal bone short, broad and thick; eye rather small; mouth large, lips well developed and strongly papillose; fins all large, caudal moderately forked; lateral line fully developed, on median line of body. Scales moderate, equal 7-52-7.

D., II ; A., 7 ; V., 9.

Colour brassy olive, the back with dark cross blotches which disappear with age; lower fins red.

A large species, sometimes reaching two feet in length. It is found in Lake Erie and is recorded by Messrs. Evermann and Goldsborough from Lake of the Woods. 


\section{Genus ERIMYZON. (Chub Suckers.)}

Body oblong, compressed; head moderate; mouth moderate, somewhat inferior, the upper lip well developed, freely protractile, the lower moderate, infolded, inversely $\mathrm{V}$-shaped in outline, plicate with twelve to twenty folds on each side; lower jaw without cartilaginous sheath, rather stronger than usual, and oblique when the mouth is closed; eye moderate; suborbital bones well developed; not much narrower than the fleshy part of the cheek below them; opercular bones moderately developed, not rugose; fontanelle rather large; gill rakers rather long; pharyngeal bones weak; the teeth quite small, slender, and weak, rapidly diminishing in length upward, each tooth narrowly compressed, with a cusp on the inner margin of the cutting surface; scales rather large, more or less crowded forward; no lateral line; dorsal fin rather short and high, rays usually eleven or twelve; pectoral fins moderate; anal fin high and short, more or less emarginate or bilobed in adult males; caudal fin moderately forked or lunate, its lobes subequal. Air bladder with two chambers.

\section{(21) Chub Sucker.}

(Erimyzon sucetta.)

Head rather short, broad above. Body oblong, rather deep, compressed. Mouth rather small and but slightly inferior, protractile. Dorsal short, rather high placed in middle of length; caudal slightly forked; no lateral line. Scales, 43-15.

D., 12 to $15 ;$ A., 7 to 8 .

Colour dusky, brassy below; young with black bands or bars and pale streaks.

Our form is probably E. sucetta oblongus. It reaches a length of about ten inches and feeds on soft-bodied insects.

\section{Genus Minytrema. (Spotted Suckers.)}

Body rather elongate, subterete, becoming deeper and rather compressed with age; scales rather large and nearly uniform in size; lateral line interrupted in the adult, but with perfect tubes, imperfect in partly grown specimens, and obsolete in the young; head moderate, rather broad above; mouth moderate, inferior, horizontal; the upper lip well developed, freely protractile; the lower rather small, infolded, inversely $\mathrm{V}$-shaped in outline, lower jaw without cartilaginous sheath; eye moderate, rather high, nearly median; suborbital bones well developed; opercular bones well developed, not very rough; fontanelle rather large; gill rakers rather long; isthmus moderate; pharyngeal bones essentially as in Moxostoma; dorsal fin rather short and high, inserted somewhat nearer to tip of snout than to base of caudal; pectoral fins moderate, placed low; anal high and 
short; ventrals short, midway between tip of snout and base of caudal; caudal fin moderately forked, the lobes equal; air bladder with two chambers. Head in males tuberculate in spring.

\section{(22) Striped Sucker.}

(Minytrema melanops.)

Body oblong, subterete; head moderate, subconical; eye small ; nostrils about over the angle of the mouth; dorsal origin over tip of pectoral; ventrals nearly under middle of dorsal. Scales large, firm, 46-I3.

D., 12 ; A., 7 ; V., 9 .

Colour dusky above, coppery below, usually a dusky blotch behind dorsal fin; scales mostly with a dark spot at the base, the spots forming longitudinal stripes. In the young there is no lateral line, but in adults it is almost entire. Old males during the spawning season in the spring have the head tuberculate.

This species is found in Lake Erie and probably occurs sparingiy in Lake Ontario also, but I have no records from that region. As a food fish it is of little value.

\section{Genus MOXOSTOMA. (Mullets; Red-horse Suckers.)}

Body moderately elongate, sometimes nearly round, usually compressed; scales large, nearly uniform in size; lateral line complete, straight or anteriorly curved; head varying in length, subconical; eye usually rather large, placed moderately high; suborbital bones very narrow; fontanelle well developed; mouth varying much in size, inferior, the mandible horizontal or nearly so; lips unusually well developed, the form of the lower varying, usually with a slight median fissure, but never deeply incised; lips with transverse folds, which are rarely broken up to form papillæ; jaws without cartilaginous sheath; muciferous system well developed; opercular bones moderately developed, nearly smooth; isthmus broad; gill rakers weak, moderately long; pharyngeal bones rather weak, the teeth rather coarser than in Erimyzon and Catostomus, strongly compressed, the lower five or six stronger than the others, which rapidly diminish in size upward, each with a prominent internal cusp; dorsal fin nearly median, moderately long: anal fin short and high, with seven developed rays; caudal fin deeply forked; air bladder with three chambers.

\section{(23) White-nosed Sucker.}

(Moxostoma anisurum.)

Body elongate, somewhat compressed, slightly arched anteriorly. Head moderate, flat and broad above. Mouth slightly inferior; upper lip thin, lower strongly V-shaped; eye large. Snout rather blunt, not projecting much beyond the mouth; fins all well developed, the dorsal large, its first ray is as long as the base of the fin; upper caudal lobe narrow and longer than the lower. Scales, 5 to $6 ; 43$ to $46 ; 4$ to 5 . 
D., I 5 ; A., 7 to $8 ;$ V., 8 .

Colour pale; caudal smoky gray; lower fins red.

This species is generally distributed through the St. Lawrence, Lake Ontario and Lake Erie regions, but is nowhere abundant. When fully developed it attains a length of about two feet.

\section{(24) Short-headed Mullet.}

(Moxostoma breviceps.)

Body deep, compressed; head small; snout short and sharply conic, overhanging the very small mouth, form suggesting that of the Whitefish; caudal fin with the upper lobe falcate and much longer than the lower; dorsal fin short, high and falcate; anal large, falcate, reaching beyond front of caudal. Scales, 6-45-5.

Colour silvery, the lower fins bright red.

This species seems to be confined entirely to Lake Erie, so far as our Province is concerned. It attains a length of about one foot and ranks with the other fresh water Mullets as food.

\section{(25) Common Mullet. Red-horse.}

(Moxostoma aureoleum:)

Body oblong, the back in front of dorsal elevated and compressed; head short, conical, broad between eyes; mouth rather small, with thick lips; snout somewhat projecting; eye rather large; caudal peduncle deep, compressed. Caudal forked. Scales large, about equal in size all over the body and finely striated, 6-46-6; lateral line complete.

D., I $5 ;$ A., 8 .

Colour olivaceous, with strong brassy reflections, paler below; tail and lower fins red.

This is the handsomest and best of all the Sucker family. It was formerly abundant in the waters of the Lakes from the St. Lawrence to Lake Superior, but owing to persistent netting during the spawing season it has become comparatively scarce. In the early spring, as soon as the ice moves out, the Mullet run up the streams to spawn, forcing their way through the swiftest torrents in order to reach the gravelly beds, upon which the ova are deposited. After spawning they retire to deep water. While in the streams they will readily take worm bait, and as they frequently attain a weight of four or five pounds they afford good sport in the swift waters they frequent.

\section{Family CYPRINidÆ. (The Carps.)}

Cyprinoid fishes with the margin of the upper jaw formed by the premaxillaries alone and the lower pharyngeal bones well developed, falciform nearly parallel with the gill arches, each provided with one to three series of teeth in small number, four to seven in the main row, and a less 


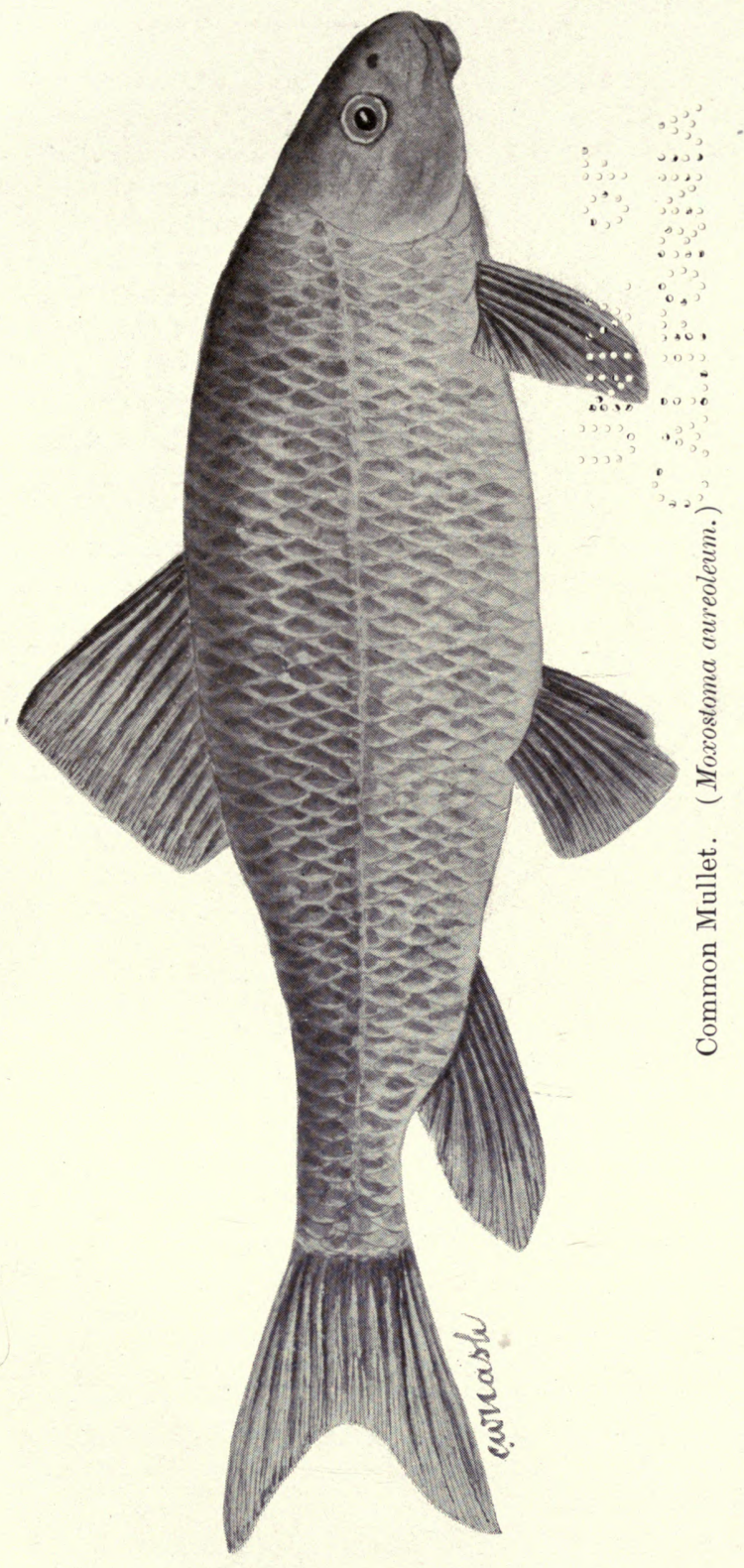



number in the others, if more are present. Head naked; body scaly in all our species. Barbels two or four; absent in most of our genera and not large in any. Belly usually rounded, rarely compressed, never serrated. Gill openings moderate, the membranes broadly joined to the isthmus. Branchiostegals always three. Gills four, a slit behind the fourth. Pseudobranchiæ usually present. No adipose fin. Dorsal fin short in all the American species. Ventral fins abdominal: Air bladder usually large, commonly divided into an anterior and posterior lobe, not inclosed in a bony capsule, rarely wanting. Stomach without appendages, appearing as a simple enlargement of the intestines. Fishes mostly of moderate or small size; very abundant both in individuals and species, and from their great uniformity in size, form, and colouration, constituting one of the most difficult groups in natural history in which to distinguish genera and species. Our genera are mostly very closely related, and are separated by characters which, although reasonably constant, are often of slight structural importance. The spring or breeding dress of the male fishes is often peculiar. The top of the head and often the fins or various portions of the body are covered with small tubercles, outgrowths from the epidermis. The fins and lower parts of the body in the spring males are often charged with bright pigment, the prevailing colour of which is red, although in some genera it is satin white, yellowish, or black.

Young Cyprinidæ are usually more slender than adults of the same species, and the eye is always much larger; they also frequently show a black lateral stripe and caudal spot, which the adults may not possess.

The fins and scales are often, especially in specimens living in small streams, covered with round black specks, immature trematodes. These should not be mistaken for colour markings.

\section{Genus CAMPOSTOMA. (Stone Rollers.)}

Body moderately elongate, little compressed; mouth normal, the jaws with thick lips and rudiment of a hard sheath; premaxillaries protractile; no barbel; teeth $4-4$ or I, 4-4, o, with oblique grinding? surface, and a slight hook on one or two teeth; air bladder suspended in the abdominal cavity and entirely surrounded by many convolutions of the long alimentary canal ; peritoneum black; pseudobranchiæ present ; scales moderate; lateral line present; dorsal nearly over ventrals; anal short; no spines. Herbivorous. Sexual differences very great, the males being covered with large tubercles in spring. The singular arrangement of the intestines in relation to the air bladder is peculiar to Campostoma among all known fishes.

\section{(26) Stone Roller. Stone Lugger.}

(Campostoma anomalum.)

Body moderately stout, not greatly compressed; the caudal peduncle long and deep. Snout obtuse. Scales, 8-52 to $53-8$. 


\section{D., 8 ; A., 7 or 8 .}

Colour brownish with a brassy lustre above, the scales mottled; a black vertical bar behind opercle; iris orange. Dorsal and anal each with a dusky cross-bar about half way up; in spring males the upper half of these fins is fiery orange. In the spawning season, the males have the head and frequently the entire body covered with large tubercles. Young, mottled brownish, the fins plain.

In this species the intestinal canal is from six to nine times the total length of the body, its numerous convolutions passing above and around the air bladder, an arrangement found in Campostoma alone among all the vertebrates (Jordan). It grows to a length of about eight inches and is widely distributed.

I have not yet found this fish in our Province, but it should and probably does occur in streams flowing into the Niagara River and into I,ake Erie.

\section{Genus CHROSOMUS.}

Body moderately elongate, little compressed; jaws normal; no barbel; teeth $5-5$ or $4-5$, moderately hooked, with well marked grinding surface; alimentary canal elongate, about twice as long as body; peritoneum black; scales very small; lateral line short or wanting; dorsal behind ventrals; anal basis short. Size small. Colours in spring brilliant, the pigment bright red.

\section{(27) Red-bellied Dace.}

(Chrosomus erythrogaster.)

Body fusiform; head conical with pointed snout; caudal moderately forked, its middle rays two-thirds as long as the outer. Scales, 18-80 to 35-10; teeth, 5-5. Length about three inches. D., 8; A., 7 ; V., 8; P., I 2. Colour, brownish olive, with black spots on the back, a blackish band from above eye straight to the tail, sometimes breaking up in spots behind; another below, broader, running through eye, decurved along the lateral line, ending in a black spot at base of caudal; belly and space between the bands bright silvery, brilliant scarlet in spring males, as are the bases of the vertical fins; the females are obscurely marked.

This species has been taken in Algonquin Park by Prof. Macoun, but I have no other records.

\section{Genus HYBOGNATHUS.}

Body elongate, somewhat compressed; mouth horizontal, the jaws normal, sharp-edged; lower jaw with a slight, hard protuberance in front; no barbel ; upper jaw protractile; teeth 4-4, cultriform, with oblique grinding surface and little if any hook; alimentary canal elongate, three to ten times the length of the body; peritoneum black; scales large; lateral line continuous; dorsal inserted before ventrals; anal basis short. Size mod- 
erate. Sexual changes very slight, no red or black pigment distinguishing the males in spring.

\section{Subgenus HYBOGNATHUS.}

\section{(28) Silvery Minnow.}

(Hybognathus nuchalis.)

Body rather slender; head rather short, the profile evenly curved; eye moderate; lateral line decurved. Caudal moderate in size and deeply forked. Scales, 6-38 to 39-4. Teeth, 4-4, long, much compressed, with a long oblique grinding surface. Intestines seven to ten times as long as the body.

Colour above, olivaceous green, translucent; sides silvery, with bright reflections; fins unspotted. Length about six inches.

Has been taken in the Lake Ontario region of New York State and will probably also occur here.

\section{Genus Pimephales. (Fat-head Minnows.)}

Body rather robust, little compressed; head short and rounded, mouth small, inferior; upper jaw protractile; no barbel ; teeth $4-4$, with oblique grinding surface, usually only one of the teeth hooked; dorsal over ventrals, its first (rudimentary) ray separated from the rest by membrane, not joined to them as usual in Minnows, this character most distinct in adult males, in which the skin of the first ray is thickened; anal basis short; intestinal canal elongate; peritoneum black; pseudobranchiæ present; scales rather small; lateral line complete or variously incomplete. Size small. Breeding males with much black pigment and with large warts on the head.

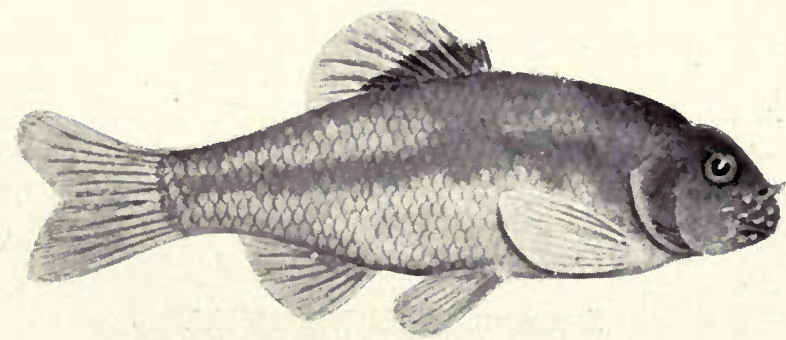

Black-head Minnow. (Pimephales promelas.)

(29) Blackhead Minnow. Fathead.

(Pimephales promelas.)

Body short, deep, and moderately thick; head short, with a very obtuse snout; mouth very small terminal, slightly oblique. Scales, 9-45 to $49-6$.

$4 \mathrm{~F}$. 
D. I., 8; A. I.: $7 ;$ V., 8; P., 18.

Colour-Males in spring dusky, with black head and the snout and chin with numerous coarse tubercles. Females much paler; both sexes have a dark lateral stripe which varies much in individuals. Some specimens I have show it clear and distinct from shoulder to the end of the caudal, while in others it is scarcely visible. There is a dark band along the base of the dorsal, widest and most distinct in front, fading out towards the rear. Length about two and a half inches.

The Blackhead is found chiefly in streams and ponds having a mud bottom. I have found it more frequently in Eastern Ontario than elsewhere. It spawns in June among the stones near the shores of its habitat.

(3o) Blunt-nosed Minnow.

(Pimephales notatus.)

Body rather elongate, with a slender caudal peduncle; head rather long, with the snout abruptly decurved. Mouth very small, inferior, nearly horizontal; caudal moderately large and forked. The lateral line curves very slightly downward as far as the ventral origin and then follows straight along the median line; it is complete. Scales, 6-42 to $45-5$. Teeth, 4-4. D. I., 8; A. I., 7 ; V., 8; P., 15.

Colour, dusky olive, lighter on sides, black spot on front of the dorsal (wanting in young). Head wholly black in spring males, the snout with fourteen large tubercles.

This is a larger species than the preceding, reaching a length of four inches. It occurs in the St. Lawrence River and may be generally distributed, but so far I have not found it in Western Ontario.

\section{Genus SEMOTilus. (Chubs. Fall-Fishes.)}

Body stout, moderately compressed and elongate; mouth terminal, wide, the upper jaw protractile; a small barbel just above the end of the maxillary; in most American Minnows the barbel is at its tip, the maxillary barbel sometimes absent in young; teeth $2,5-4,2$, hooked, without grinding surface; scales rather large, lateral line complete; a short intestinal canal; dorsal placed behind ventrals; base of anal short. Vertebræ, $22+20=42$.

\section{SubgeNus LEUCOSOMUS.}

\section{(3I) Chub. Horned Dace.}

(Semotilus corporalis.)

Body moderately deep, elongate, with a stout caudal peduncle; head rather large; snout pointed; mouth oblique, jaws nearly equal, the maxilla extending to below front of eye. The caudal is large and deeply forked. The lateral line curves downward abruptly over the pectoral, becoming 



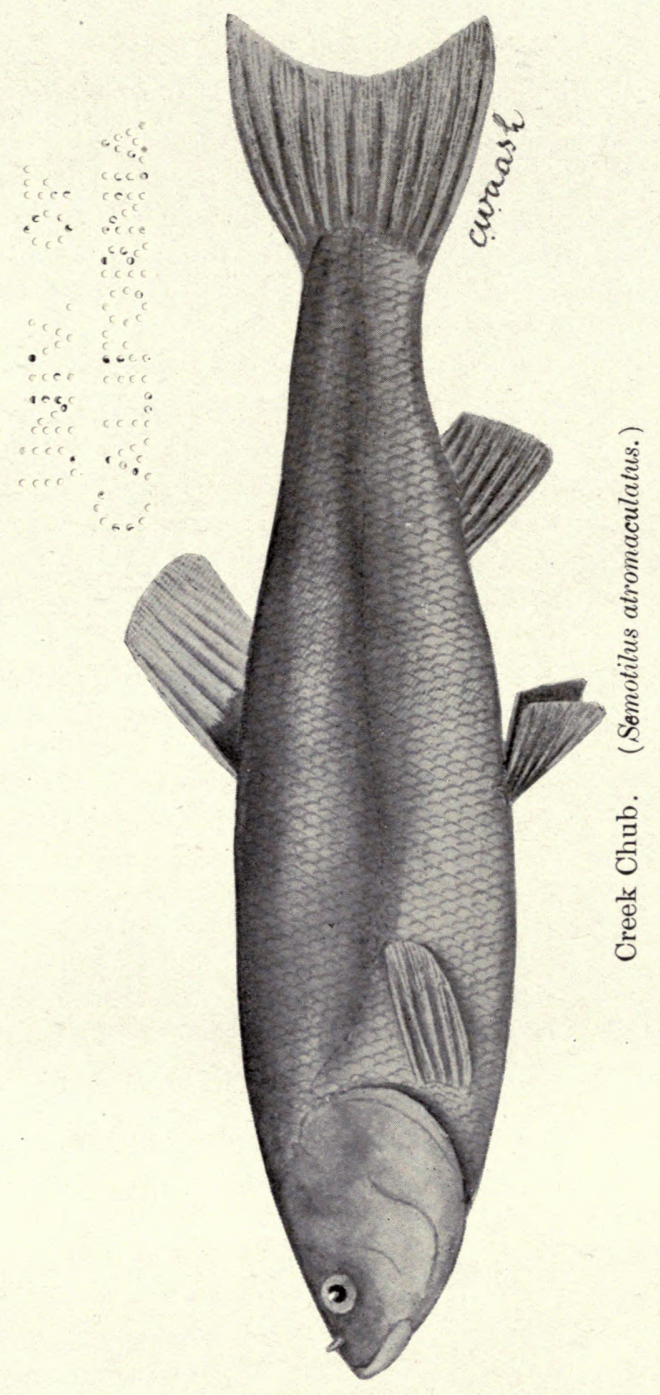


median over the end of that fin. Scales, 7-46-5. A small barbel on maxillary.

D. II., 7; A. II., 7 ; V., 8; P., I8.

Colour, upper parts steel blue; sides and belly silvery, fins unmarked. In spring the males have the belly and lower fins flushed with deep rose. This is the largest representative of the Minnow tribe in our waters, under favorable circumstances attaining a length of eighteen inches. It frequents streams and mill-ponds, spawns in June, and is most abundant in the eastern part of the Province. This fish is eatable, but its flesh is not greatly esteemed.

\section{Subgenus SEMOTILUS.}

\section{(32) Creek Chub. Horned Dace.}

(Semotilus atromaculatus.)

Body slender and moderately elongate; head thicker than the body and rather short; eye rather small and placed high. Mouth moderate, very slightly oblique, the jaws subequal, or the lower slightly included. Maxillary barbel minute (not evident in the young). The lateral line is abruptly bent downward over the first half of the pectoral, straight and nearly median durlng the rest of its course ; caudal moderate and not very deeply forked.

Scales, 9-58-6. D. II., 7 ; A. III., 8; V., 8; P., I5.

Colour, bluish brown above; sides with a distinct dusky band, which becomes obsolete in the adult. Young specimens have the end of this band more pronounced, forming a black spot at the base of the caudal. A small black blotch always present on the front of the base of the dorsal. Belly whitish. Males in the spring have the belly rose-tinted and coarse tubercles on the snout. This species sometimes attains a length of twelve inches; it is very abundant and generally distributed in all the streams of Ontario. As a food fish it does not take high rank, though it affords a great deal of sport for rural school boys. It spawns in early summer on the stony shallows in the streams it frequents.

\section{Genus LEUCisCUS. (DAcE.)}

Body oblong, compressed or robust, covered with moderate or small scales; lateral line decurved, complete, or variously imperfect; mouth usually large and terminal, the lips normal, without barbel; teeth mostly $2,5-4,2$, but somewhat variable, hooked, with rather narrow grindingt surface or none; anal basis short or more or less elongate; dorsal fin posterior, usually behind ventrals; intestinal canal short. Size generally large, some species very small. A very large group, one of the largest current genera in ichthyology, represented by numerous species in North America. 


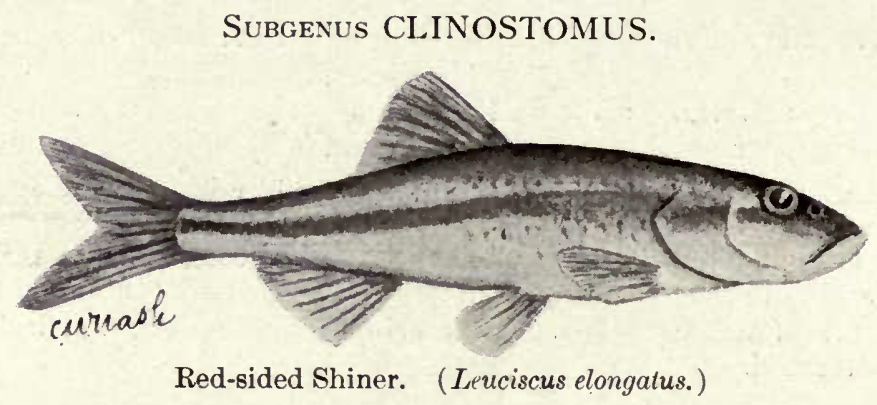

(33) Red-sided Shiner.

(Leuciscus elongatus.)

Body elongate, fusiform with long and slender caudal peduncle; head large, with long pointed snout. Mouth wide, with projecting lower jaw. Caudal large and deeply forked. The lateral line is abruptly decurved over the front half of the pectoral.

D. III., 7; A. III., 7; V., 8; P., I4. Teeth, 2, 5-5, 2, hooked, some of them with a narrow grinding surface. Colour, dusky bluish, somewhat mottled; a broad black lateral band, the front half of which is bright crimson in spring males and which is persistent in most specimens through the summer.

A very abundant species found in most streams in southern and central Ontario. One of the handsomest of our creek fish.

\section{Genus ABRAmis. (Bream.)}

Body subelliptic; strongly compressed, both back and belly curved; back narrowly compressed, almost carinated; belly behind ventral fins forming a keel over which the scales do not pass. Head small, conic; mouth small, oblique or horizontal, without barbels; scales rather large; lateral line continuous, strongly decurved; dorsal fin inserted behind the ventrals; anal fin with its base more or less elongate; teeth $5-5$, hooked, with grinding surface, the edges more or less crenate or serrate; alimentary canal short, though rather longer than the body.

\section{Subgenus NOTEMIGONUS.}

(34) Butterfish. Golden Shiner.

(Abramis crysoleucas.)

Body somewhat elongate, much compressed; head short, low, compressed, mouth small, oblique, the maxillary not reaching eye; lateral line much decurved. The dorsal fin higher than long, situated on middle of body. Caudal forked. Scales, 10-53-3. Teeth, 5-5, hooked and with grinding surface.

D., $8 ;$ A., I3. 


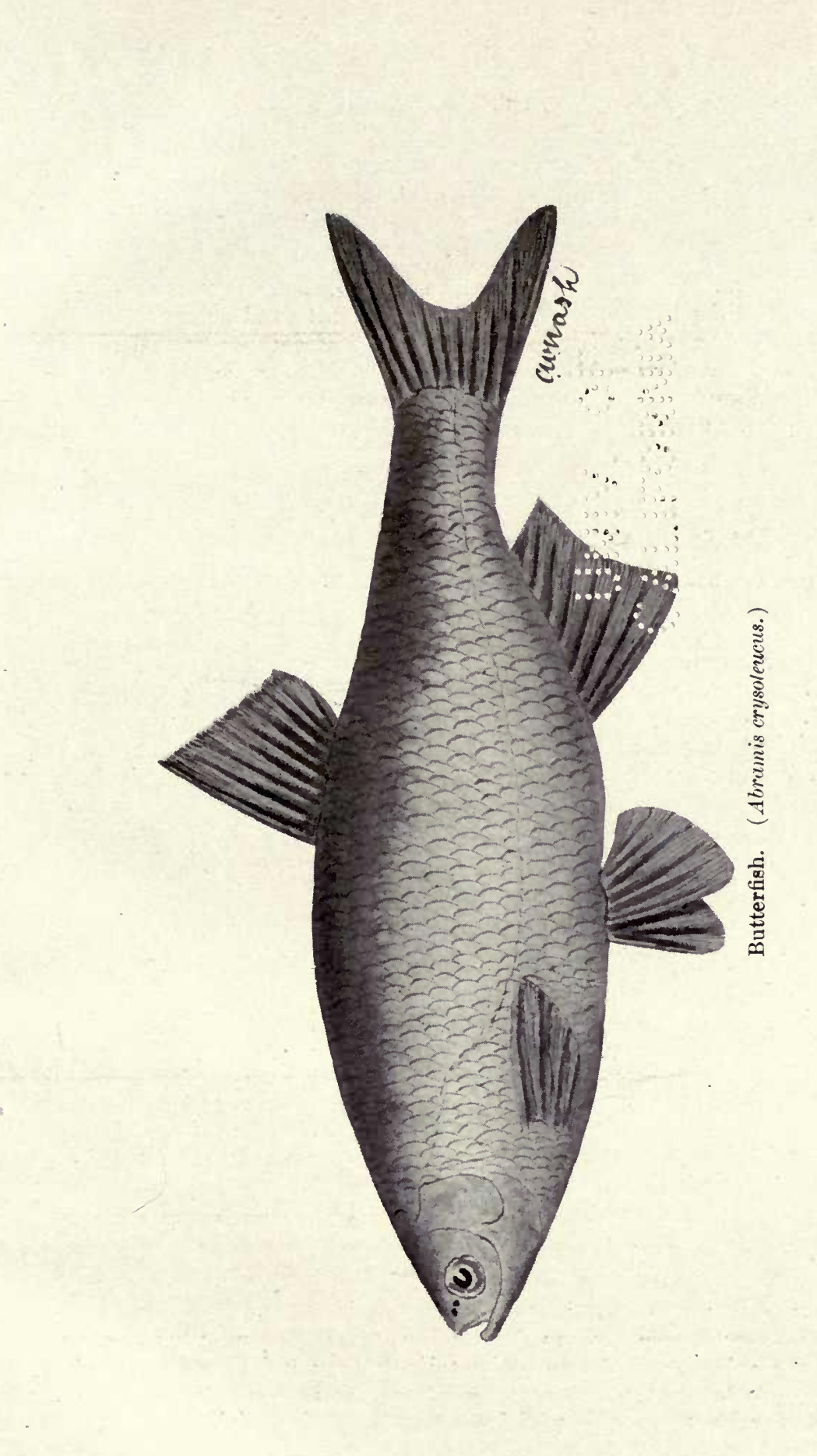


$\because:$

$\because \ldots \quad$ ㅇ..

मक है

है।

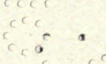

...

foes ace

$\therefore$ ic aces

$\because:$ 
Colour, greenish above, sides silvery in the young; with strong golden reflections in adults; fins yellowish. Length about ten. inches.

An abundant fish in quiet weedy waters throughout the southern and central part of the Province. Its flesh is edible, but soft and weedy flavoured. Spawns in early summer.

\section{Genus CLIOLA.}

Form and appearance of Pimephales, the same squammation, fin rays and plan of colouration, and the first ray of the dorsal similarly separated by the membrane; the structure of the mouth similar, but with the intestinal canal short, shorter than body, the peritoneum pale and the teeth more hooked, as in Notropis. The genus is very near Pimephales, although in its technical characters it approaches nearer to Notropis.

\section{(35) Bullhead Minnow.}

(Cliola vigilax.)

Body rather stout, compressed, with deep tail; head heavy, blunt; snout short, decurved; mouth terminal, slightly oblique; teeth strongly hooked; scales in front of dorsal small, crowded.

Scales, 8-42-6. D. I., 8 ; A., 7 .

Colour, pale olivaceous with a plumbeous lateral band, always ending in a black spot at base of caudal; a conspicuous black spot on middle of front of dorsal. Resembles Pimephales notatus, but distinguished by the short intestine, larger mouth, paler colouration, with more definite markings. Length, three inches.

Jordan and Evermann record this fish from Detroit. It therefore will probably be found in the waters of southwestern Ontario.

\section{Genus NOTROPIS. (Shiners.)}

Body oblong or elongate, more or less compressed; mouth normal, mostly terminal and oblique, sometimes subinferior; no barbels; teeth in one or two rows, those of the larger row always 4-4, hooked, sharp edged, or with a narrow grinding surface; scales large, often closely imbricated, those before the dorsal rarely very small; lateral line complete or nearly so, usually decurved; dorsal fin inserted above, or more usually behind the ventrals; anal fin short or moderately long, abdomen rounded, never sharp edged. Colouration more or less silvery, often brilliant, the males in spring usually with red or white pigment and the head with small tubercles. A very large group of small fishes, specially characteristic of the fresh waters of eastern North America.

\section{SubGenus CHRIOPE.}

\section{(36) Notropis cayuga.}

Head four and one-sixth; depth; four and a-half; eye three and ahalf; scales, thirty-six. Teeth, 4-4. Lateral line wanting on some scales; 
mouth very small, anterior, the maxillary not reaching the eye; jaws subequal; eye large. Scales above dark edged, the outlines very sharply defined; chin not black; a black stripe through snout and eye, a dusky lateral shade and a small caudal spot.

Length, two and a-half inches.

As this species ranges from New York State westward to Assiniboia it will no doubt be found in Ontario, but I have not yet seen it.

\section{(37) Notropis muskoka.}

Colour olivaceous, darker above, very pale below; a dark band about two-thirds diameter of eye around snout and on sides to base of caudal fin; on the snout this band is confined to the upper jaw; between this band and the darker colour on the dorsal region is a lighter band of about the same width; a dark vertebral line present, also a similar.one from base of anal to caudal fin. The lateral line is less developed in this species than in any other of the genus.

It differs from Notropis cayuga in the reduced size of the scales before the dorsal fin, the more slender body, less blunt snout, and the slightly larger and more oblique mouth and the more incomplete lateral line. It is also a larger fish than Notropis cayuga.

Twenty-four specimens varying in length from 1.31 to 2.83 inches were taken from the lower part of Gull Lake, Muskoka, and from the outlet just below the first falls.

This species is new. It was discovered and taken by Dr. S. E. Meek in September, I899.

\section{(38) Notropis heterodon.}

Body moderately stout, the back somewhat elevated; head rather pointed, the snout acuminate; mouth oblique, lower jaw projecting; lateral line usually more or less imperfect. Scales, 5-36-3. Teeth, 4-4, often crenate.

Colour olivaceous; chin black; a blackish.rostral band; sides with a dusky band. Length two and a half inches.

Ranges from the St. Lawrence River westward.

\section{Subgenus ALBURNOPS.}

\section{(39) Notropis fretensis.}

Slender, compressed; mouth oblique; eye three and a half in head; lateral line decurved. Scales, 6-35-3. Colour, olive, a plumbeous lateral shade and dark spot at base of caudal. Length two and a half inches.

This somewhat doubtful species is recorded by Jordan and Evermann from the Great Lake region and Detroit River. 


\section{(40) Straw-colored Minnow.}

(Notropis blennius.)

Body slender, elongate, its greatest depth one-fifth of total length without caudal ; head rather large ; eye large ; mouth small, inferior, horizontal, snout very obtuse. Scales, 5 to $6-32$ to $38-4$. D., 8 to $9 ; \mathrm{A} ., 7$ to 8 .

Colour pale, olivaceous; sides usually pale, usually a darker dorsal band and a small dark blotch before dorsal, sometimes a plumbeous lateral stripe, but no caudal spot; fins all plain. Length about two and a half inches.

Range from the upper St. Lawrence through the region of the Great Lakes. Lake of the Woods (Evermann and Goldsborough).

\section{(4I) Notropis volucellus.}

Body moderately stout. Head depressed, the snout rather long. Fins more elongate than in most related species, the pectorals reaching ventrals. Caudal peduncle slender.

D., 8 ; A., 8 ; scales, 4-34-3.

Colour, olivaceous, a slight dusky lateral shade; no dorsal stripe, fins plain. Length, two and a-half inches.

This species has been found in the Detroit River. I have no othes records from our, waters.

\section{Subgenus HUDSONIUS.}

(42) Spawn-eater. Smelt.

(Notropis hudsonius.)

Body moderately elongate, compressed. Head conical, with short, blunt snout; mouth small, nearly horizontal, the lower jaw very slightly the shorter. The lateral line is slightly curved downward over the pectoral, straight and median for the rest of its course. Caudal large and deeply forked, its middle rays half as long as the outer. Scales, 7-38-5. Teeth, $2,4-4$, I or 2 , with a narrow grinding surface on at least two.

D., 8 ; A., 8 or $9 ;$ V., 8 ; P., I4.

Colour, pale olive, young always with a round black spot at base of caudal; sometimes a dark lateral band; fins unmarked. Length, ten inches.

Common and generally distributed in the lakes and larger streams from the upper St. Lawrence to Lake Superior. The northern form of Lake Superior is N. h. selene.

\section{Subgenus CYPRINELLA.}

\section{(43) Silverfin.}

(Notropis whipplii.)

Body moderately elongate, fusiform in the adult. Caudal peduncle short and stout. Head conical, compressed, snout pointed. Mouth mod- 
erate terminal, slightly oblique, jaws nearly equal. The caudal is large and moderately forked. The lateral line curves downward over the pectoral. Scales 6-38 to $4 \mathrm{I}-4$; teeth, I, 4-4, I. D., 8 ; A., 9; V., 8; P., I 4 . Colour, bluish silvery; scales dusky edged; a dark vertebral line; a narrow and long black blotch on the membrane of the dorsal between the sixth and seventh and another between the seventh and eighth rays. Lower fins pale. Males in spring have the fins partly or wholly charged with white pigment and in the height of the breeding season the pigment in the dorsal has a greenish tint and the top of the head and snout is covered with minute tubercles.

Length, about four inches.

It is found in the St. Lawrence and Great Lakes region.

\section{SUBgENUS LUXILUS.}

(44) Shiner. Redfin. Dace.

(Notropis cornutus.)

When young the body is moderately elongate, but it becomes deeper with age and much compressed; caudal peduncle short. Head short, deep and thin; mouth moderate, terminal, little oblique, lower jaw included; eye moderate; the lateral line descends in a long curve, becoming straight and median over the anal origin; caudal large and deeply forked. Scales, 7-40 to $4 \mathrm{I}-4$. Teeth, $2,4-4,2$, with narrow grinding surface.

D., 8 ; A., 9; V., 8; P., 15.

Colour, upper parts steel blue with a gilt line along the back; scales dusky at edge and base. The sides are bright silvery overlaid with a gilt line. In spring males the belly and lower fins are bright rosy and the head and nape covered with small tubercles. It attains a length of about eight inches; under favourable circumstances perhaps a little more.

This handsome fish is abundant in all streams of any size throughout the Province, particularly so in those where rapids alternate with deep pools and eddies.

It spawns in early summer on stony shallows.

As a food fish it is of no value, its flesh being soft and tasteless, but it is unexcelled as bait for Maskinonge, Bass, etc.

N. c. frontalis is the form commonly found in the lakes.

\section{SUbGenUS NOTROPIS.}

\section{(45) Notropis jejunus.}

Head four; depth, four and two-thirds; eye rather large. Body rather slender; head flattish above, the snout blunted and rounded; mouth rather large, oblique.

Dorsal over ventrals; 16 scales before dorsal.

D., 8; A., 7 ; scales, 5-37-3; teeth, 2, 4-4, I.

Colour pale with a broad silvery lateral band overlying a plumbeous shade; dorsal sometimes punctulate. Length, three inches. 


$$
\mathbb{V}
$$




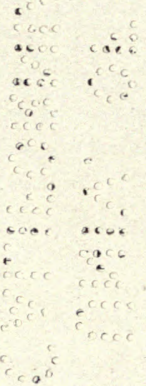


This species is recorded by Evermann and Goldsborough from Lake of the Woods and Rainy River.

\section{(46) Notropis atherinoides.}

Head, four and two-thirds; depth, five and a half; eye three and a quarter. Body long and slender, compressed, the back not elevated. Head blunt, conic, proportionately shorter than in related species. Mouth moderate, very oblique, upper lip on level of upper part of pupil ; maxillary about reaching front of eye. Eye large, rather longer than snout. Fins low; dorsal well behind ventrals; tips of ventrals extending to beyond middle of dorsal. Lateral line decurved.

D., 8; A., I I ; scales, 5-38-3; I 5 before dorsal; teeth, 2, 4-4, 2.

Colour translucent green above; sides bright silvery; scales above faintly punctate, but not enough so to render them dark-edged, nor to form blotches along sides; a faint dark vertebral line; males in spring with the snout rosy. Length, four to six inches.

This species ranges from the St. Lawrence River through the Great Lake region to Manitoba.

\section{(47) Notropis rubrifrons.}

Head, four; depth, four and three-quarters; eye, four. Body moderately elongate, the back scarcely elevated, caudal peduncle somewhat contracted. Head longer than in most related species, conic and rather pointed. Mouth rather large, very oblique, upper lip above line of middle of pupil, maxillary reaching to opposite cye. Eye moderate, anterior, usually shorter than the sharp snout.

D., 8; A., Io; scales, 5-39-3, those before dorsal large, 15 to 17 in number; teeth, 2, 4-4, 2, little hooked.

Colour olivaceous above; scales with darker edges; sides silvery; a dark vertebral line; a row of dark dots along base of anal; males with the snout tuberculate in spring; the forehead, opercular region and base of dorsal being then flushed with red.

Length, two and three-quarters inches.

This species is recorded from the St. Lawrence River and Lake of the Woods (Evermann and Goldsborough).

\section{(48) Redfin Minnow.}

\section{SubgenUS LYTHURUS.}

\section{(Notropis umbratilis.)}

Body compressed, the caudal peduncle long; head long, conical, rather pointed; mouth large, moderately oblique lower jaw somewhat projecting; eye moderate; scales closely imbricated, crowded anteriorly; dorsal fin high, inserted about midway between ventrals and anal; pectorals not reaching ventrals; caudal long; lateral line much decurved. Scales, 9-40 to 52-3. Teeth, 2, 4-4, 2. D., 7; A., I I. 
Colour, dark steel blue above; pale or silvery below. A more or less evident black spot at base of dorsal in front; the fins otherwise all plain. Males with the anterior dorsal region and the head profusely covered with small whitish tubercles, the belly and lower fins being of a bright brick red in the spring. Females very pale olive, sometimes almost colourless.

This species is recorded by Dr. Tarleton $H$. Bean as ranging from Western New York to Minnesota. It should therefore be found in the waters of Western Ontario, but as yet I have not seen it. Our form would probably be N. u. lythrurus.

\section{Genus RHINICHTHYS. (Black-Nosed Dace.)}

Body moderately elongate and little compressed, with usually stout caudal peduncle and long, conical nose; head rather large, sometimes broad and flat above; eye small; mouth small, subinferior, the upper jaw fixed by the union of the upper lip to the skin of the forehead; end of maxillary with small barbel. Teeth, 2, 4-4, 2 (sometimes 2, 4-4, I), those of the principal row usually hooked, without grinding surface. A short intestinal canal; scales very small; lateral line decurved, continuous; dorsal origin slightly behind ventral; base of anal short. Small fishes inhabiting clear, cold, brooks and streams.

\section{(49) Long-nosed Dace. Niagara Gudgeon.}

(Rhinichthys cataractæ.)

Body elongate, subterete; caudal peduncle stout; head moderate; eye rather above median; mouth horizontal, small, placed under the snout, the lower jaw the shorter; upper lip thick; barbel evident but small; caudal, large and well forked; scales, 13-57 to 65-10. Teeth, 2,4-4, 2, three of the principal row hooked. D. II., 7 ; A. II., 6; V., 8; P., I 2.

Colour, dusky olive, the back darker, below pale, some of the scales mottled irregularly with dark and olivaceous, no black lateral band in the adult, but in the young there is a trace of a dusky band. Males in the spring have the lips, cheeks and lower fins crimson. Length, about five inches.

This species is found from the Niagara River to Lake Superior. It is not uncommon at Sault Ste. Marie.

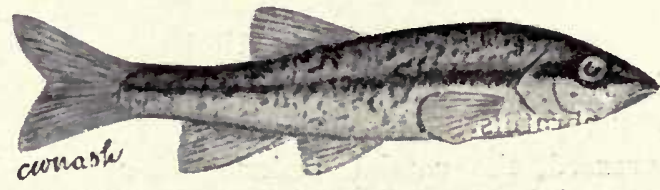

Black-nosed Dace. (Rhinichthys alronasus.)

(50) Black-nosed Dace.

(Rhinichthys atronasus.)

Body long, somewhat stout; head small, conical; eye small; mouth small, slightly oblique, with nearly equal jaws; the maxillary barbel small 
or wanting. The dorsal origin is nearer to root of caudal than to tip of snout; caudal small and not deeply forked. The lateral line curves down over the pectoral, soon becoming median. Scales, I0-56 to $63-10$. Teeth, $2,4-4,2$, three of the principal row strongly hooked. D. II., 6 or 7 ; A. II., $6 ;$ V., 8 ; P., II.

Colour dusky blackish, mottled above, whitish below, a black lateral band, bordered above and below by pale. Spring males have the lateral band and ventral fins crimson or orange. In some adult specimens I have the dark lateral band is entirely wanting. Dr. Philip Cox, of New Brunswick, who finds both this and the preceding species in that Province, says: "These two species are with us very closely related and present at all times such instability of characters as to suggest intergrading." Length, about three inches.

Very common in all streams of the Lower Lakes and St. Lawrence region. In the Upper Lake region it is represented by $R$. a. obtusus.

\section{Genus HYBOPSIS. (Horny-heads.)}

Body robust or variously elongate; mouth terminal or inferior, with lips thin or somewhat fleshy, a conspicuous barbel always present and terminal on the maxillary; a second barbel sometimes present on each side; premaxillaries protractile. Teeth $4-4$ or I, 4-4, I, or 0 ; hooked, the grinding surface narrow or obsolete. Scales usually rather large; lateral line continuous. Dorsal inserted over, in front of, or slightly behind ventrals; anal basis short. Males usually with nuptial tubercles, and sometimes flushed with red. A large and varied group closely allied to Notropis, from which it differs chicfly in the presence of the small maxillary barbel.

\section{SUBgENI'S ERIMYSTAX.}

\section{(5 I) Spotted Shiner.}

(Hybopsis dissimilis.)

Body long and slender, caudal peduncle long and low; head long, snout obtusely rounded at the point; projecting beyond the small mouth. The gill openings are separated by a broad isthmus. Caudal moderately large and deeply forked. Barbels conspicuous. Scales, 6-4.3 to $47-5$. Teeth, 4-4, hooked and with a short grinding surface. D. II., 8; A. II., 6; V., 7; P., 1.5 .

Colour, above olivaceous, below silvery, the lateral band is dusky, on which are several dark spots; the band is carried forward through the eye and around the snout; fins pale. Length, about six inches.

This species occurs in the Lower Lakes and rivers falling into them. It is probably more abundant in Lake Erie than clsewhere.

$5 \mathrm{~F}$. 


\section{SUBGENUS HYBOPSIS.}

\section{(52) Lake Minnow.}

(Hybopsis storerianus.)

Body rather elongate; back elevated, ascending gradually to beginning of dorsal, then descending to the caudal fin; head short, interorbital space broad, flat; mouth rather small, horizontal, the lower jaw included; barbel conspicuous; snout abruptly decurved, the tip thickened; lateral line somewhat decurved; fins high; dorsal inserted well forward, over ventrals; pectoral fins pointed; caudal long, deeply forked. Scales, 5-42-4. D., 8 ; A., 8 .

Colour, greenish above; sides and below brilliant silvery; fins plain. Length, about eight inches.

This fish has been taken in Lake Ontario waters and also in Lake Erie, but I have no other records.

\section{Genus COUESIUS.}

Body elongate; head normal, not depressed, the profile convex; mouth terminal, normal, a well developed barbel on the anterior side of maxillary, just above its tip. Teeth, $2 ; 4-4,2$, hooked without grinding surface. Scales rather small; lateral line continuous. Dorsal fin over or slightly behind ventrals; anal basis short. Size rather large. This genus is closely related to the section Nocomis under Hybopsis, from which it may be separated by the presence of two teeth in the lesser row, by the position of the barbel, and by the smaller scales. Its relations with Semotilus are equally close.

\section{(53) Lake Chub.}

(Couesius plumbeus.)

Body moderately elongate and somewhat compressed; head rather flat above, not much raised above the level of the eyes; maxillary reaching to below front of orbit, a small barbel placed high at its tip; lower jaw included. Lateral line beginning high up on the nape, abruptly descending to the median line over the pectoral fin, and thence running nearly straight to the caudal fin. Dorsal origin midway between tip of snout and base of caudal fin. Caudal deeply forked. Scales small, r 3-65-8. Teeth, 2, 4-4, 2.

Colour dusky above, sides silvery with a plumbeous lateral band; fins plain. Length, about six inches.

This species ranges through Canada from New Brunswick to Lake Superior and is tolerably common throughout; more especially northward. The Lake Superior form is C. p. dissimilis.

\section{Genus EXOGLOSSUM.}

Body rather short and stout, subterete; lower jaw three lobed, the dentary bones being close together and completely united, not forming a 
wide arch as in the minnows generally; upper jaw not protractile; pharyngeal bones small, the teeth hooked, and without grinding surface, I, 44, I. Scales moderate; lateral line complete. Dorsal origin is nearly over the beginning of the ventral ; anal fin short; isthmus broad; gill rakers weak; pseudobranchial present, air bladder normal; alimentary canal short; peritoneum white. Size large. No marked sexual peculiarities; the males with some black pigment in spring. One of the most strongly marked genera of Cyprinidæ.

\section{(54) Cut-lips. Stone-toter.}

(Exoglossum maxillingua.)

Body rather short, and stout; caudal peduncle short and deep. Snout short and obtusely conical, lower jaw included; eye small. Caudal moderately forked. Ṡcales, 9-54-6. Teeth, I, 4-4, I. D., 8; A., 7 .

Colour, dusky olivaceous, darker above; a short and narrow dark bar above the root of pectoral; young with a dusky bar at the caudal base. Fins dusky, with pale extemities.

This fish may be readily distinguished by the three-lobed lower jaw, the dentary bones being closely united and the lower lip represented by a fleshy lobe on each side of the mandible.

Length, about six inches.

The Stone-toter has not a very wide range; it is found in the St. Lawrence River and in Lake Ontario, but does not appear to be abundant.

\section{Genus CYPRINUS. (CARP.)}

Body robust, compressed; mouth moderate, anterior, with four long barbels; snout blunt, rounded; teeth molar, broad and truncate, I, I, 33, I, I ; scales large; lateral line continuous; dorsal fin very long, with a stout spine, serrated behind; anal fin short, also with a spine. Large fishes of the fresh waters of Asia; introduced into Europe and America as food fishes.

\section{(55) Carp. (Introduced.)}

\section{(Cyprinus carpio.)}

Body stout, moderately elongate; head comparatively small; mouth moderate, the upper jaw not extending to front of eye; a barbel on the upper lip and another on the angle of the mouth at each side. Caudal strongly forked. Scales, 5-38-5. D. III., 20; A. III., 5; V. I., 7 ; P., I 5 .

Colour, above dusky, the sides and below golden olive.

There are three varieties of this species, the German or Scale Carp, the Mirror Carp, and the Leather Carp, the distinction between them being based upon the scale arrangement. The Leather Carp is nearly without scales. The Mirror has a few scales of unequal size, irregularly placed; 
while the German variety has the body completely covered with scales, this last being the most abundant form in our waters.

No greater mistake was ever made than the introduction of this fish into North American waters. In England, where it is well known, it was considered about the most worthless fish they had and one of the most difficult to get rid of, where once it had become established. On some parts of the continent of Europe, however, where good fish are scarce, the Carp was cultivated and fed in ponds with care and probably because the people knew no better, it was more appreciated. In this country, where fish of the highest quality should be obtainable by every one, there is no place for the Carp.

De Kay states that it was first introduced into New York waters in 1831. In 1870 it was taken to California and in 1877 the United States Fishery Commissioners imported a considerable number and propagated them only too successfully. Since then they have spread into all accessible waters and have become an unbearable nuisance wherever found, for not only are they damaging our fisheries, but also by reason of their destruction of the wild rice beds they are causing the wild fowl to avoid the feeding grounds to which they formerly resorted during the autumn flight.

The food of Carp consists principally of insects and vegetable matter, preferably, perhaps, of the seeds, young shoots and tender roots of aquatic plants; when feeding it constantly grubs up the bottom, thereby stirring the mud and keeping the water in such a dirty condition that none of our valuable fish will remain in it.

The spawning season in our waters commences in June and seems to last until August. The fish are very prolific, make rapid growth, and attain a large size, specimens weighing over twenty pounds having frequently been taken in American waters, while in Europe they have beer known to reach ninety pounds.

\section{Order APODES. (The Eels.)}

Teleost fishes with the premaxillaries atrophied or lost, the maxillaries lateral, and the body anguilliform and destitute of ventral fins. The most striking feature is the absence of the premaxillaries, taken in connection with the elongate form and the little development of the scapular arch, which is not attached to the cranium. Other characters not confined to the Apodes are the following: The absence of the symplectic bone, the reduction of the opercular apparatus and of the palatopterygoid arch, the absence of ventral fins, the absence of the mesocoracoid or præcoracoid arch, and the reduction or total absence of the scales. There are no spines in the fins, the gill openings are comparatively small, and there are no pseudobranchiæ. The vertebræ are in large number and none of them are specially modified. The tail is isocercal; that is, with the caudal vertebræ remaining in a straight line to its extremity, as in the embryos of most fish. 



$$
b
$$




\section{Suborder ENCHELYCEPHALI.}

The characters of this group are as given above.

\section{Family ANGUillide. (The True Eels.)}

The true Eels are characterized by their conical head, well developed opercular apparatus, lateral maxillines, cardiform teeth, distinct tongue, vertical lateral branchial apertures, continuous vertical fins, with the dorsal far from the head, pectorals well developed, scaly skin, and nearly perfect branchial skeleton.

The Anguillidæ approach more nearly than most of the Eels to the type of the true fishes. In one respect, however, that of the minute ova and concealed generation, they differ widely from these.

\section{Genus ANGUILla. (Eels.)}

Body elongate, subterete, compressed posteriorly, covered with embedded scales which are linear in form and placed obliquely, some of them at right angles to others. Lateral line well developed. Head long, conical, moderately pointed, the rather small eye well forward and over the angle of the mouth. Teeth small, subequal, in bands on each jaw and a long patch on the vomer. Tongue free at tip. Lips rather full, with a free margin behind, attached by a frenum in front. Lower jaw projecting. Gill openings rather small, slit like, about as wide as base of pectorals and partly below them. Nostrils superior, well separated, the anterior with a slight tube. Vent close in front of anal. Dorsal inserted at some distance from the head, confluent with the anal round the tail. Pectorals well developed.

\section{(56) American Eel.}

(Anguilla chrysypa.)

Body much elongated, round through most of its length, compressed behind; head conical, elongated; snout pointed; lower jaw longer than the upper; gill openings partly below the pectoral fins; small and slit-like. Scales imperceptible, deeply embedded and very irregularly placed. Lateral line very distinct. Colour above olive brown more or less tinged with yellowish; below grayish to pure white. Length; thirty inches.

In our Province the Eel is only found in the St. Lawrence and Lake Ontario and their tributaries, the Falls of Niagara forming an insurmountable obstacle to further progress inland.

Until recently the reproduction of the Eel has been involved in mystery, but the careful investigations of competent observers have resulted in showing that the Eel spawns in salt water, usually on mud banks off the 
mouths of rivers, to which they resort in late autumn. When the young Eels are from two to three inches long they ascend the rivers in vast numbers, travelling continually until they meet some obstacle which cannot be overcome. Professor Baird has estimated "that in the summer one may see hundreds of waggon loads of young Eels at the foot of Niagara Falls, crawling over the rocks and squirming in the seething waters." Where the obstruction to their passage permits it, the fish will leave the water and travel through wet grass in order to continue their journey.

As a food fish Eels are justly esteemed and in the markets they always sell for a high price.

\section{Order ISOSPONDYLI. (The Isospondylous Fishes.)}

Soft-rayed fishes with the anterior vertebræ simple, unmodified, and without auditory ossicles; symplectic present; no interclavicles; opercular bones distinct; pharyngeal bones simple above and below, the lower not falciform. Mesocoracoid arch always well developed, forming a bridge from the hypercoracoid to the hypocoracoid. Bones of jaws developed, the maxillary broad, always distinct from premaxillary, and forming part of margin of upper jaw; no barbels. Shoulder girdle well developed and connected with the cranium by a bony post-temporal. Gills four, a slit behind the fourth. Air bladder, if present, with a pneumatic duct. Dorsal and anal fins without true spines. Ventral fins abdominal, sometimes wanting. Scales usually cycloid, sometimes ctenoid; occasionally wanting. No developed photophores. Adipose fin present or absent.

\section{Family hiOdONTIDA. (The Moon-eyes.)}

Body oblong, much compressed, covered with moderate sized, brilliant, silvery, cycloid scales. Head naked, short, the snout blunt. Mouth moderate, oblique terminal, the jaws about equal. Premaxillaries not protractile. Maxillary small, slender, without evident supplemental bone, articulated to the end of the premaxillary and forming the lateral margin of the upper jaw. Dentition very complete; premaxillary and dentary bones with small wide-set cardiform teeth; maxillaries with feeble teeth ; row of strong teeth around the margin of the tongue, those in front very strong canines; between these is a band of short close-set teeth; vomer with a long double series of close-set, small teeth; similar series on the palatines, sphenoid and pterygoids; sides of lower jaw fitting within the upper, so that the dentaries shut against the palatines. Eye very large, the adipose eyelid not much developed. Preorbital very narrow. Nostrils large, those of each side close together, separated by a flap. Gill membranes not connected, free from the isthmus, a fold of skin covering their base. No gular plate. Branchiostegals eight to ten. Gill rakers few, 


short and thick. Pseudobranchia obsolete. Lateral line distinct, straight. Belly not serrated. Dorsal fin rather posterior; anal elongate, low; ventrals well developed; caudal strongly forked; no adipose fin. Stomach horseshoe-shaped, without blind sac; one pyloric cæcum. Vertebræ, about sixty. Air bladder large. No oviducts, the eggs falling into the carity of the abdomen before exclusion.

\section{Genus HIODON. (MoOn-Eyes.)}

The generic characters are included abovt.

\section{Subgenus HIODON.}

\section{(57) Mooneye.}

(Hiodon tergisus.)

Body oblong, much compressed; the belly with a slight but obtuse keel in front of ventrals and a rather sharp edge behind them; head short, snout rounded; eye large ; caudal deeply forked.

D., $12 ;$ A., 28 to 32 .

Colour, back bright olive green; sides and abdomen brilliantly silvery. Length, twelve inches or a little more.

This species ranges from the St. Lawrence to Lake Superior and is particularly abundant in Lake Erie. It is a very handsome and good game fish, taking bait very readily, but its flesh is of no value as food.

\section{SubGenus AMPHIODON.}

\section{(58) Gold-eye. Northern Mooneye.}

(Hiodon alosoides.)

Body deep, much compressed; head short, eye moderate, the snout very blunt; mouth large and oblique, the maxilla reaching beyond the middle of the eye. The ventral edge of the body carinated. Scales, 6-56-7. D., 9 ; A., 32 .

Colour, bluish above, sides silvery with a golden lustre. Length, about twelve inches.

I have no positive record of the occurrence of this fish in Ontario waters, but I have no doubt that it will be found in the lakes and rivers near the Manitoba boundary. In Manitoba it is very abundant and is the best sporting fish found in the prairie rivers. It takes grasshoppers and small frogs, or even pieces of fish very readily, and in early summer rises well to an artificial fly. Its flesh is particularly well flavoured and firm. and is much valued as food. 


\section{Family DOROSOMIDE. (Gizzard Shads.)}

Body short and deep, strongly compressed, covered with thin, deciduous cycloid scales. Belly compressed to an edge, which is armed with bony serratures. Head naked, short, and rather small. Mouth small, inferior, oblique, overlapped by the blunt snout; no teeth; maxillary narrow and short, with a single supplemental bone, not extending to opposite middle of eye, and forming but a small portion of lateral margin of upper jaw; mandible short and deep, its rami enlarged at base; premaxillaries not protractile. Gill rakers slender, exceedingly numerous, not very long, similar on all the arches. Gill membranes not united, free from the isthmus; branchiostegals about six; pseudohranchial large. An adipose eyelid. No lateral line. Dorsal fin about midway of the body, usually behind ventrals. Pectorals and ventrals moderate, each with an accessory scale. Anal very long and low ; caudal forked. No adipose fin. Vertebræ, forty-nine. Stomach short, muscular, like the gizzard of a fowl.

\section{Genus DOROSOMA. (Gizzard Shad.)}

Body herring-like, much compressed and covered with moderately large, thin, cycloid scales. Snout short and obtuse. Head scaleless, short and small. Eye large and provided with an adipose eyelid. The belly is compressed to an edge, which is armed with sharp serratures. Mouth small, transverse; the lower jaw the shorter, jaws toothless. The maxilla does not extend to the middle of the eye. Gill rakers numerous, moderately long and slender; gill membranes deeply cleft and free from the isthmus; pseudobranchiæ well developed; lateral line wanting. The dorsal fin is placed nearly over the middle of the body, slightly behind the origin of the ventral. Its last ray is produced into a long filament. The pectorals and ventrals are rather long and each is provided with an appendage formed of several elongate, overlapping accessory scales. The caudal is deeply forked. Anal very long, its last rays low.

\section{(59) Gizzard Shad.}

(Dorosoma cepedianum.)

Body deep, compressed; the scales thin, deciduous; head small; snout short, blunt; mandible enlarged at base; gill rakers very slender, not very long; an adipose eyelid. Dorsal about median, the filamentous ray nearly as long as head. Caudal widely forked, the lower lobe longer than upper; belly sharply serrate.

Colour, upper parts bluish ; sides silvery, sometimes with golden reflections; in the young there is a large dark blotch on each side not far behind the head; this disappears with age.

Length, about fifteen inches; it sometimes attains a weight of about iwo pounds. 
This fish has worked its way from the Ohio and Mississippi Valleys through the canals to Lake Erie, where in some places it is not uncommon.

It is a handsome species, but is of no value for food.

\section{Family ClUPEid e. (The Herrings.)}

Body oblong, or elongate, more or less compressed, covered with cycloid or pectinated scales. Belly sometines rounded, sometimes compressed, in which case it is often armed with bony serratures. Head naked, usually compressed. Mouth rather large, terminal, the jaws about equal ; maxillaries forming the lateral margins of the upper jaw, each composed of about three pieces. Premaxillaries not protractile; teeth mostly small, often feeble or wanting, variously arranged. Adipose eyelid present or absent. Gill rakers long and slender; gill membranes not connected, free from the isthmus. No gular plate. Gills four, a slit behind the fourth. Branchiostegals usually few (six to fifteen). Posterior lower part of opercular region often with an angular emargination, the tips of the larger branchiostegals being abruptly truncate. Pseudobranchia present. No lateral line. Dorsal fin median or somewhat posterior, rarely wanting. No adipose fin. Ventrals moderate or small. Anal usually rather long; caudal fin forked. Vertebræ, forty to fifty-six.

\section{Genus POMOlobus. (Alewives.)}

Body oblong, more or less compressed; mouth moderate, terminal, the jaws about equal, or the lower projecting, the upper scarcely notched at tip ; teeth feeble, variously placed, probably never wholly absent, mandibles very deep at base, shutting within the maxillaries; gill rakers more or less long and slender, numerous; adipose eyelid present; scales thin, cycloid, deciduous, entire, rounded posteriorly; cheeks with the free part longer than deep; dorsal fin rather short, nearly median, beginning in advance of ventrals, its posterior ray not prolonged in a filament; ventrals present; anal moderate; belly compressed, strongly serrated before and behind ventrals.

\section{(6o) Gold Shad. Sawbelly.}

(Pumolobus chrysochloris.)

Bouy compressed, rather low, the caudal peduncle stout and the belly strongly serrated; head slender, rather pointed, lower jaw strongly projecting, maxillary reaching posterior part of the eye. Eye large, nearly one-fourth the length of head; fins moderate, caudal deeply forked. Scales, I $5-5^{2}$ to $5^{8}$.

D. III., I $5 ;$ A. III., I6.

Colour, above blue; below silvery, with golden reflections on sides. Length, about eighteen inches. 
The Gold Shad has made its way into the Great Lakes through canals from the Ohio and Mississippi Valleys, where it is abundant.

Unlike most of its tribe, this is a predaceous fish, feeding largely upon small fry. It may be readily captured with minnow bait, but as a food fish it is not esteemed.

(61) Gaspereau. Alewife.

(Pomolobus pseudoharengus.)

Body deep and heavy forward, much compressed. Head short, nearly as deep as long; eye large, deeper than long. Maxillary broad; upper jaw emarginate, lower jaw slightly projecting. Anal low; caudal deeply forked, partially scaled near base. Scales, I5-50 to 54 . D., I6; A., I7 to 19.

Colour, above bluish; silvery on sides; a black spot behind head. On large specimens there are faint dusky lines along the rows of scales.

Length, about ten inches, or rather more; in Lake Ontario, however, they rarely exceed eight inches in length.

This fish is said to have been introduced into Lake Ontario in 1873 by mistake, the intention having been to stock the water with shad. Whether this is correct or not, the Gaspereau is now firmly established here, and in spite of the vast numbers which die every summer, it seems to be increasing. From early in March until early in November they are to be found near the shores of Lake Ontario and in the St. Lawrence, but are at the height of their abundance during June and July, and it is during these months that the great mortality takes place, millions of dead fish being cast up on the shore and the surface of the water being liberally strewed with the dead and dying. Where they go in the cold months of winter is uncertain, probably only into the deep water of the lake, though it is possible that they may work their way down to the Gulf of St. Lawrence.

They are eatable, but being small and bony are not much appreciated.

\section{Genus ALOSA. (The Shad.)}

Body deep, compressed, deeper than in related American genera; the head also deep; the free portion of the cheeks deeper than long; jaws wholly toothless (except in young); upper jaw with a sharp, deep notch at tip, the premaxillaries meeting at a very acute angle.

\section{(62) Shad.}

(Alosa sapidissima.)

Body deep; mouth large, with the jaws about equal; gill rakers very long and slender. In the female the dorsal originates a little in front of the middle of the length, in the male somewhat farther in front. The dorsal of the male is rather higher than that of the female, while the body is not so deep. Scales, $16-60$ to 65 . The dorsal has thirteen divided rays and four simple, and the anal nineteen divided and three simple. 


$$
l
$$




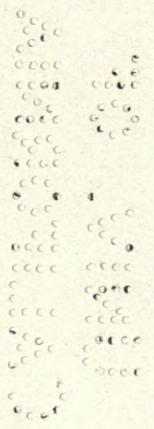


Colour, bluish above; sides and below silvery; usually a dark blotch behind opercle and of ten several in a row behind this; peritoneum pale.

The Shad is an anadromous fish which passes most of its life in the ocean, migrating annually up the rivers for the purpose of spawning in the spring. It was formerly abundant in the lower Ottawa, but has abandoned that river and its occurrence within our boundaries is now only accidental.

As a food fish it ranks very high, being one of the most esteemed fish of America.

\section{Family SALMONIDA. (The Salmons.)}

Body oblong or elongate, covered with cycloid scales. Head naked. Mouth terminal, large or small, varying much in the different genera; maxillary forming the lateral margin of the upper jaw, provided with a supplemental bone; premaxillaries not protractile. Teeth various, sometimes wanting. Gills four, a slit behind the fourth. Pseudobranchix present. Gill rakers various; gill membranes not connected, free from the isthmus; branchiostegals ten to twenty. No barbels. Dorsal usually nearly median, not greatly elongate, its rays nine to fifteen, only one or two of the anterior simple or rudimentary, the others branched; adipose fin present; caudal fin forked; anal fin moderate or rather long; ventrals moderate, nearly median; pectorals placed low. Lateral line present. Abdomen rounded in outline. Parietals not in contact; separated at middle by the intervention of the supraoccipital, which connects with the frontals; epiplural appendages not developed. Air bladder large, stomach siphonal; pyloric cæca very numerous. Ova large, falling into the cavity of the abdomen before exclusion.

As now restricted, this is no longer one of the large families of fishes, but in beauty, activity, gaminess and quality as food and even in size of individuals, different members of the group stand easily among the most valuable of our fishes.

The Salmonidæ are confined to the northern regions and north of about $40^{\circ} \mathrm{N}$. are everywhere abundant in suitable waters. Some of the species, especially the larger ones, are marine and anadromous, living and growing in the sea and entering fresh waters to spawn; others live in running brooks, entering lakes or the sea as occasion serves, but not habitually doing so; while others, again, are lake fishes, approaching the shore or entering brooks in the spawning season, at other times retiring to waters of considerable depth. Some of them are active, voracious and gamy, while others are comparatively defenceless, these latter can rarely be captured upon a baited hook.

The large size of the eggs and their lack of adhesiveness, with the ease by which the eggs may be obtained and impregnated, render the most of the species especially adapted for artificial culture.

$6 \mathrm{~F}$. 
The Salmonidæ are of comparatively recent evolution, none of them occurring as fossils, unless it be in recent deposits. The instability of the specific forms and the lack of sharply defined specific characters may be in part attributed to their recent origin.

\section{Genus COREGONUS. (Whitefishes.)}

Body oblong or elongate, compressed; head more or less conical, compressed, the snout more or less projecting beyond the lower jaw ; mouth small, the maxillary short, not extending beyond the orbit, with a well developed supplemental bone; teeth extremely minute, if present; scales moderate, thin, cycloid, rather firm. Dorsal fin moderate; caudal fin deeply forked; anal fin somewhat elongate; ventrals well developed. Pseudobranchiæ large; gill rakers varying from short and thickish to long and slender; air bladder very large; vertebræ, fifty-six to sixty; stomach horseshoe-shaped, with about one hundred pyloric cæca; ova small.

Most of them spawn in late fall or winter near the shore, at other seasons often frequenting considerable depths.

The number of species of Coregonus has been overestimated and the geographical range and range of variation of each one are much wider than is generally supposed.

All our species are highly valued as food and they probably constitute the most important class commercially of our fresh water fish.

\section{Sulzgenus PROSOPIUM.}

\section{(63) Frost-fish. Round Whitefish.}

(Coregonus quadrilateralis.)

Body slender, elongate, subterete; head long, the snout compressed and bluntly pointed. Scales, 9-85-8. D., I I ; A., 10.

Colour, upper parts dark bluish; sides silvery.

Length, about twelve inches; it seldom attains much more than one and a-half pounds in weight.

The Frost-fish is abundant in the Great Lake region from the St. Lawrence to Lake Superior and northward, and is everywhere highly esteemed as a food fish.

It spawns in October and November, visiting the shallow parts of lakes and sandbars for that purpose.

\section{Subgenus COREGONUS.}

\section{(64) Common Whitefish.}

(Coregonus clupeiformis.)

Body deep, compressed; back always more or less elevated, notably so in the adult; caudal peduncle short; head small and short, the snout blunt and obliquely truncated. Scales, 8-74 to 80-9. Dorsal, ten divided rays; anal, eleven divided rays. 


$$
\text { : }
$$





$$
f
$$




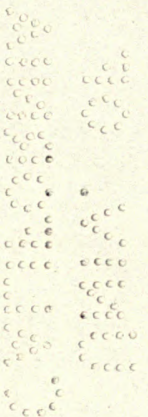


Colour, upper parts pale olivaceous; sides and below white, somewhat lustrous.

This Whitefish under favourable circumstances reaches a large size. One taken in Lake Erie a few years ago measured thirty-three inches in length, twenty-five inches in cicumference, and weighed twenty pounds. One taken at Whitefish Point, Lake Superior, weighed twenty-three pounds. Another taken in Lake Erie in 1876 weighed seventeen pounds. Such fish are, however, now very rare in this Province. In Manitoba they are less uncommon. The average length of adults on our markets in these days will be about twenty inches and the weight about three pounds or a little more.

It ranges through the Great Lakes region from the St. Lawrence to Lake Superior, and thence westward to Alaska; where it is replaced by a closely allied form; its northern limit is not positively known.

Although this is one of the most abundant and at the same time the most valuable of our commercial fish, its habits are not yet fully understood; undoubtedly they vary very much according to locality; the depth of water, currents or their absence, and climatic conditions all having some influence on the movements of the fish in search of food, and upon the time and place of spawning. In some of our lakes there is a movement of the Whitefish in early summer from the deep water into shoal water near the shore; towards midsummer they retreat to the deep and cold parts of the lake, where they spend most of their time. In the autumn they again move in towards the shore, seeking their spawning grounds; these are chiefly rocky reefs and shoals, composed of what is known as honeycomb rock. It is said that gravelly and sandy shoals are sometimes resorted to for spawning purposes, but this is doubtful.

Spawning takes place in October and November and may possibly be extended by some few individuals, or under exceptional circumstances, into December; both the time of spawning and of incubation depend largely upon the temperature.

The autumn movement commences in September, but does not become general until October; the fish then continue to run in greater or less numbers until the spawning is ended, when they again retire to deep water for the winter. It is a curious fact that even during the spawning season a large number of Whitefish are always to be found in the deep water, but there is no evidence that they ever spawn there.

\section{(65) Sault Whitefish.}

(Coregonus labradoricus.)

Head, five; depth, three and a half to four; eye large. Gill rakers short, about two to two and a half in eye, $10+15$ or 16 .

Body rather elongate, compressed, the back not elevated. Head rather small, slender, compressed. Mouth rather small, the lower jaw short, snout projecting; the maxillary reaching front of pupil; maxillary 
bone broad, rather short, its supplementary piece ovate. Mandible reaching middle of eye. Tongue with about three series of small teeth. Supraorbital bone narrow. Dorsal fin high in front, the last rays short:

D., I I or I 2 ; A., I I or I 2 ; Scales, 10-7 I to 76-9.

Colour, bluish black above; silvery below; scales with dark punctulations on the edges; fins all dusky, pectorals and ventrals pale at the base.

Length, twenty-one inches.

A very variable species, by some authorities considered indistinguishable from C. clupeiformis.

Generally distributed in cold, clear lakes and large streams, especially northward.

\section{Genus ARgyrosomus. (Ciscoes.)}

This genus is very close to Coregonus, from which it differs in the larger mouth and more produced jaws, the premaxillaries being placed nearly horizontally, and the lower jaw decidedly projecting beyond them. Gill rakers very long and slender, about thirty on lower limb; vertebrie, fifty-five. These characters are associated with the geater voracity, and in general greater activity of the species of Argyrosomus.

\section{SUbGENUS ARGYROSOMUS.}

(66) Cisco. Lake Herring.

(Argyrosomus artedi.)

Body long, slender, and somewhat compressed; dorsal and ventral outlines but little arched; head pointed; mouth large, jaws subequal or the lower somewhat projecting; maxillary long, usually reaching to vertical of pupil. Caudal peduncle slender, but not much compressed; dorsal fin small; adipose fin slender, its width one-half its height.

D., I I ; A., io (counting only divided rays in dorsal and anal); V., io.

Colour, above dull bluish green; lower part of sides and below silvery white. Dorsal fin sometimes black tipped; caudal dusky at tip; anal and ventrals pure white.

This species attains a length of about twelve inches and a weight of about one pound. Larger specimens have been recorded, but they are exceptional.

The Cisco ranges through the Great Lakes generally, but is most abundant in Lake Erie; it was formerly common in Lake Ontario. Of late years, however, it has not been taken there in any quantity. Its spawning season is in November and early December. 




\section{(67) Long-jaw Herring. Lake Herring.}

(Argyrosomus prognathus.)

Body oblong, much compressed, back elevated, the body tapering rather sharply toward the narrow caudal peduncle; the adult having a slight nuchal hump as in C. clupeiformis; mouth large and strong; snout straight, its tip on a level with the lower edge of pupil; mandible very long, projecting beyond upper jaw when the mouth is closed; reaching to or beyond posterior edge of the eye; head rather short, deep and pointed; cranial ridges prominent, dorsal rather high; origin of dorsal nearer tip of snout than base of caudal. Scales rather large, about seventy-five in lateral line; seven or eight above the lateral line; seven or eight below the lateral line. Lateral line straight except at origin, where it presents a rather marked curve.

Colour, sides of body uniformly bright silvery, with pronounced bluish reflection in life; back dusky; under parts pure white, without silvery. Above the lateral line the upper and lower edges of the scales finely punctulate with dark, the central part unmarked, producing light longitudinal stripes extending whole length of body. Fins flesh colour or pinkish in life, the dorsal and caudal usually showing dusky edges; postorbital area with bright golden reflection; iris golden, pupil black.

D., 9 or ro; A., ro to I 2.

Average length, about fifteen inches.

This fish may readily be distinguished from any other white fish found in the Great Lakes by the general form of its body, together with the very long lower jaw.

It is taken in all the Great Lakes except Lake Erie, from which as yet no specimens have been reported. In Lakes Ontario and Michigan it is particularly abundant, and is highly esteemed as a food fish.

There is much difference of opinion among fishermen as to the spawning time of the Long-jaw, which seems to extend over a prolonged period. Fish with matured roe have been taken as early as May $17^{\text {th }}$, and ripe fish have also been reported from Lakes Ontario and Huron late in June and through July. Very little is positively known as to the location of the spawning grounds of this species,-though it is said that they are in deep water.

(68) Black-fin Whitefish.

(Argyrosomus nigripinnis.)

Body stout, fusiform; head and mouth large; lower jaw slightly projecting; back not arched, profile from occiput to origin of dorsal fin very gently curved; eye rather large; teeth very feeble, but appreciable on the maxillaries and tongue.

D., 12 ; A., 12 .

Scales on lateral line, 73 to 77 , above lateral line nine or ten, below seven or eight. 
Colour, dark bluish above; sides silvery, with dark punctulations; fins all blue-black.

This species may be readily known by its black fins.

During the last few years the Black-fin has been occasionally reported from Lake Superior; its centre of abundance, however, appears to be Lake Michigan and the deep water lakes of Minnesota and Wisconsin.

In its habits it resembles the other members of the group, swimming in shoals and depositing its spawn upon rocky bottom in November and December.

It reaches a length of eighteen to twenty inches and is considered a good food fish.

\section{Subgenus ALLOSOMUS.}

\section{(69) Tullibee. Mongrel Whitefish.}

(Argyrosomus tullibee.)

Body short and deep compressed, the dorsal and ventral outlines similarly curved; head small, conic and compressed; mouth large, lower jaw slightly projecting. Scales larger on front of body than on caudal peduncle; free margins of the scales less convex than in other species, often emarginate, especially on anterior part of body. Lateral line straight and in a line with upper rim of orbit; tongue with a patch of fine teeth near the tip; gill rakers numerous, long and slender.

D., Io to I 2 ; A., I I or I 2.

Scales on lateral line, 68 to 74 , eight or nine rows above and seven or eight below.

Colour, iridescent bluish above, sides and under parts silvery; old individuals darker above, with some golden reflections on side; fins more or less evidently black tipped; upper edge of pectoral margined with black.

From all other Whitefishes the Tullibee may be distinguished by the short steep body and the closely imbricated scales. It attains a length of eighteen or twenty inches and a weight of about three and a half pounds. As a food fish it is highly esteemed, but its commercial importance is as yet limited.

This species is usually called the Tullibee, but it is sometimes styled the "Mongrel Whitefish" on the erroncous supposition that it is a cross between the Whitefish and the Lake Herring.

In the Great Lakes it is not at all common, occurring in limited numbers in Lakes Erie and Superior only, but in the Lake of the Woods and through Manitoba and Assiniboia it is abundant.

Mr. F. C. Gilchrist, in describing the habits of this fish in Western Canada, says: "In September they will be found gradually nearing the shoal water, feeding heavily, plump with fat and the now swelling ovaries. Later on they appear to eat little or nothing and devote all their time to playing until about the $25^{\text {th }}$ of October, when they settle down to the 



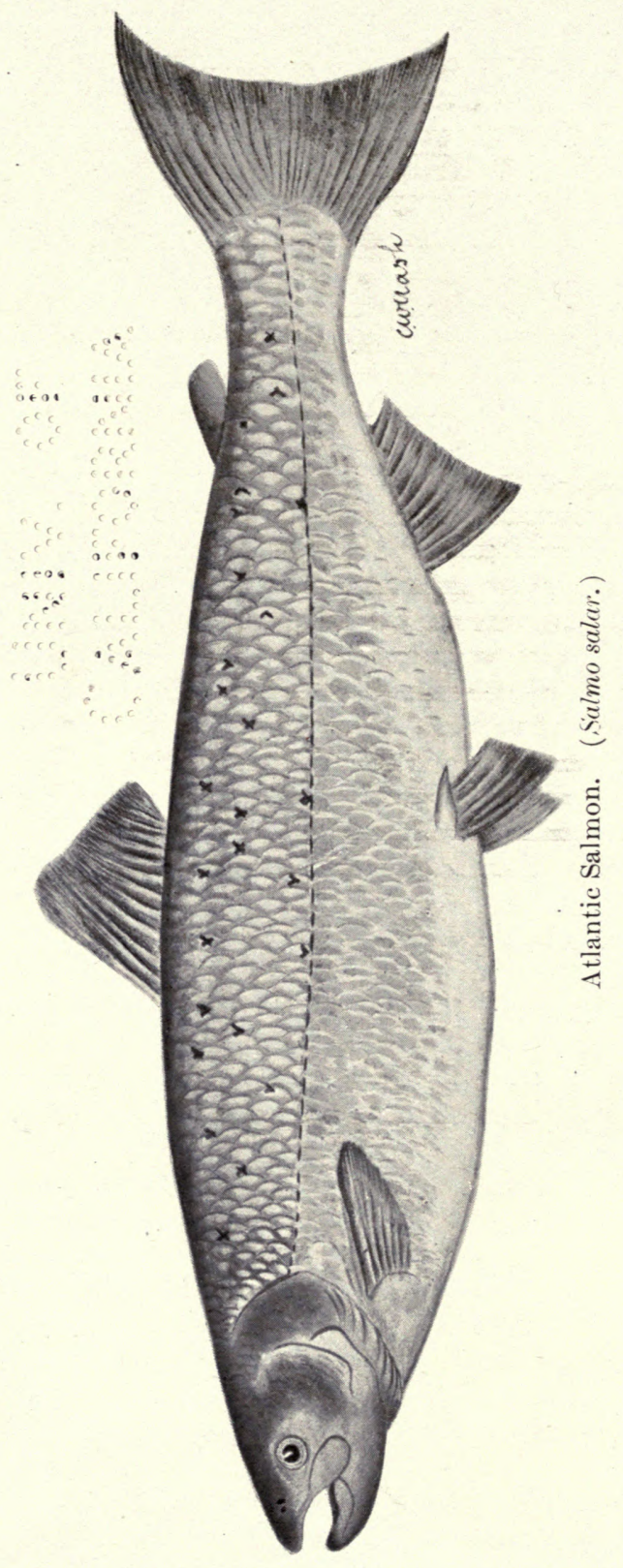


business of propagation, which is finished by November Ioth. They prefer shallow water close to the shore, with clean sand to spawn on, and during the day they may be seen in pairs and small schools, poking along the shores, but at night they come in thousands and keep up a constant loud splashing and fluttering, very strange and weird on a calm night. Two years ago I carefully counted the ova from a ripe fish two and a half pounds in weight, and found there were 23,700 , closely resembling Whitefish eggs in appearance, but somewhat smaller. After spawning the fish are very thin, lank, dull in colour, and quite unfit for human food.'

\section{Genus SAlmo. (Salmon and Trout.)}

Body elongate, somewhat compressed; mouth large, jaws, palatines and tongue toothed, vomer flat, its shaft not depressed, a few teeth on the chevron of the vomer, behind which is a somewhat irregular single or double series of teeth, which in the migratory forms are usually deciduous with age; scales large or small, one hundred and ten to two hundred in a longitudinal series; dorsal and anal fins short, usually of ten to twelve rays each; caudal fin truncate, emaryinate or forked, its peduncle comparatively stout; sexual peculiarities variously developed, the males in typical species with the jaws prolonged and the front teeth enlarged, the lower jaw being hooked upward at the end and the upper jaw emarginate or perforate. In the larger and migratory species these peculiarities are most marked. Species of moderate or large size, black spotted.

\section{Subgenus SALMO.}

(7o) Atlantic Salmon.

(Salmo salar.)

Body moderately elongate, symmetrical, not much compressed; head rather low and comparatively small; mouth moderate, the maxillary reaching just past the eye; in the young the maxillary is proportionately shorter. Scales comparatively large, rather larger posteriorly, silvery and well imbricated in the young, becoming embedded in the adult males.

Colour: In the adult the upper parts are brownish or grayish, the sides silvery. Numerous $x$ or $\times \times$ shaped black spots on the upper half of the body, side of the head and on the fins. Males in the breeding season have red blotches along the sides. In the young there are from ten to twelve dark crossbars mingled with red blotches and black spots. D., I I divided rays and 3 rudiments; A., 9 divided rays and 3 rudiments. Scales, $23, \mathrm{I} 20,2 \mathrm{I}$.

In the early pioneer days the Atlantic Salmon was abundant in the St. Lawrence and the Lake Ontario waters as far as Niagara Falls, which formed an insurmountable obstacle to their further progress. They may now, however, be considered as extinct in this Province. The destruction 
of the timber along the banks of the rivers and the consequent pollution of the water having fouled the spawning beds to such an extent that the fish can no longer resort to them. An occasional specimen is taken in Lake Ontario by the fisherman, but these visitors are probably merely wanderers from the hatcheries below. The range of the Salmon in Canada extends from Quebec eastward through the Maritime Provinces, thence northward along the Atlantic coast to Hudson Strait, and for about one hundred miles down the east coast of Hudson Bay.

The usual weight of the Atlantic Salmon ranges up to about forty pounds, but specimens of sixty or more have been taken. The greater part of its growth takes place in the ocean, in which the fish spends about half its life. In the spring or early summer the adults enter rivers, working their way up to shallow water, on a sandy or gravelly bottom. On this the eggs are deposited in late autumn, the spawning season beginning about the middle of October, and it may continue until December. The eggs are large, about a quarter of an inch in diameter, and very numerous, an eight-pound female yielding from five to six thousand eggs and heavier fish a proportionately greater number. The hatching period ranges from one hundred and forty to two hundred days, depending upon the temperature. When newly hatched the fry are about three-fourths of an inch long. At two or three months old and about two inches long, they begin to show the vermillion spots and dark cross bands and are then called "parr"; this name and colouration they retain while they remain in fresh water. In the second or third spring they assume a uniform bright silvery colour and descend to the sea, at this stage being known as "smolt." After remaining in salt water for a period varying from a few months to about two years, the fish may return to their native river, either as a "grilse" or "salmon" weighing from two to six pounds. Towards winter they again return to the sea, and from this time forward the migration from the sea to river head waters is performed annually.

It is generally assumed that salmon take no food while in fresh water, yet they certainly rise readily enough to the artificial lure of the angler, more particularly when fresh run from the sea; therefore it seems probable that in the early part of the season the fish will feed, but that as spawning time approaches they, like some other species, cease to have any desire for food and devote themselves to the duties of reproduction entirely, for while on the spawning ground and after the ova are deposited the salmon grow lank and thin, losing all their beauty. In this condition they are "kelts" and valueless as food.

\section{Subgenus TRUTTA.}

(71) Steelhead Salmon.

(Salmo gairdneri.)

Body elongate, little compressed, much like S. salar in form; caudal peduncle short; head rather short, maxilla reaching far behind the eye. 


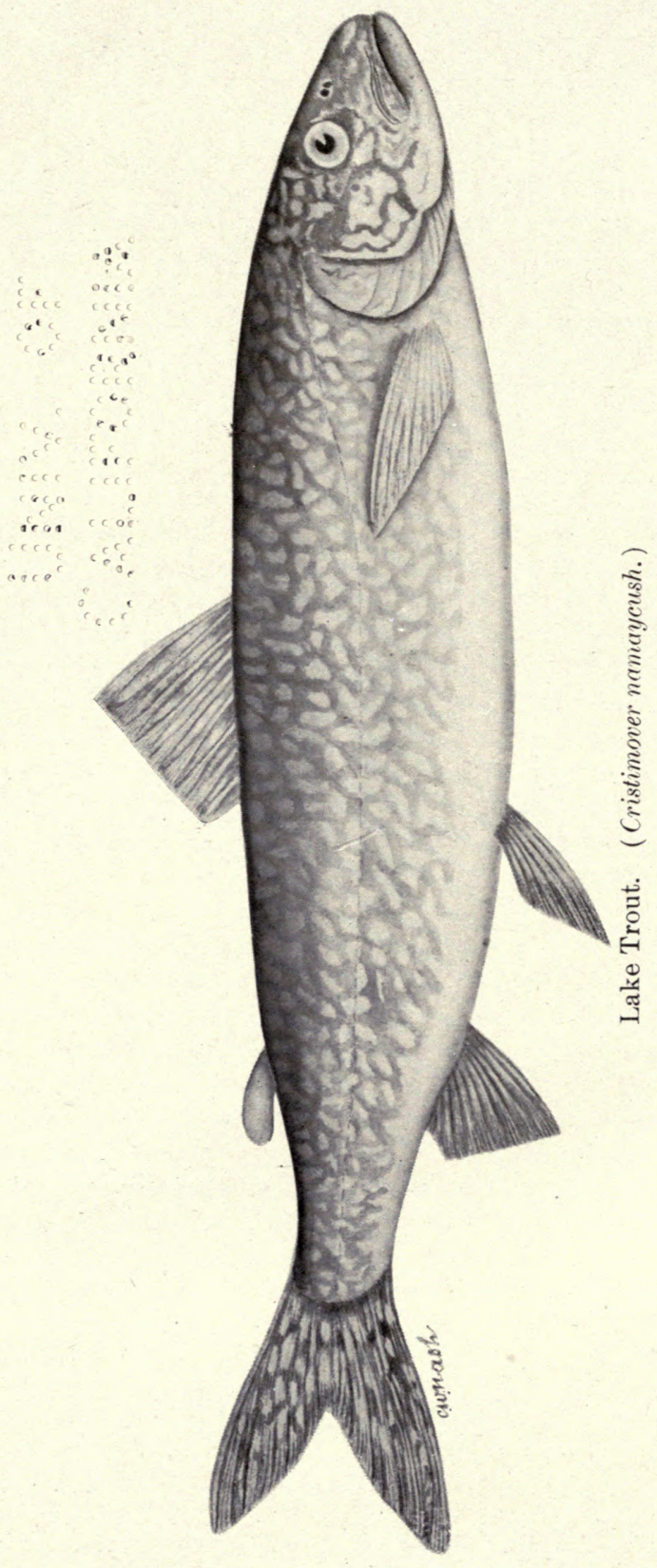


Eye small. Teeth rather small; vomerines in two long, alternating series, about as long as the palatine series; gill rakers short and stout; about twenty, on the first arch of which twelve are below the angle; dorsal origin much nearer to tip of snout than to base of caudal; adipose fin very small and narrow, over the beginning of the anal; caudal fin moderately forked in the young; ventral origin midway between tip of snout and base of caudal.

D., I I A., I 2. Colour, olive green above, sides silvery, head, back, dorsal and caudal fins profusely covered with small black spots, no red between the rami of the lower jaw.

I mention this fish because it has been introduced with marked success into Lake Superior and tributary waters by the United States Fish Commission, and specimens have been taken on our side of the lake, where it is to be hoped it will find a congenial habitat, for it ranks very high as a game and food fish, attaining under favourable circumstances a weight of about twenty pounds.

\section{Genus CRISTIMOVER. (LAke Trout.)}

This genus contains one, or perhaps two, species, large, coarse Charrs, distinguished from Salvelinus by the presence of a raised crest behind the head of the vomer and free from the shaft; this crest is armed with teeth. The hyoid teeth constitute a strong cardiform band. The typical species is a large Charr, spotted with gray, and found in the larger lakes of eastern North America.

(72) Lake Trout. Salmon Trout. Gray Trout. Togue. Tuladi. (Cristimover namaycush.)

Body long; caudal peduncle slender; head long, its upper surface flattened; eye large, placed near top of head; mouth very large, the maxillary extending much beyond the eye; the origin of dorsal midway between tip of snout and root of tail; caudal fin well forked; adipose fin small; teeth very strong.

D., 9 to II;A., 9 to II. Scales, about 200 on lateral line.

The colouration is extremely variable, generally grayish, sometimes pale and sometimes almost black, everywhere with rounded pale spots which are often reddish tinged; on the back and top of the head there are fine vermiculations resembling those of the Brook Trout. The dorsal and caudal with pale spots and dark markings.

This species is found in nearly all the large lakes from New Brunswick west to British Columbia and north from Labrador through the Hudson's Bay country to Alaska. It is the largest-species of the family resident in fresh water, reaching a length of several feet and a weight of sixty pounds or even more, though specimens exceeding twenty pounds are now rare. 
The Lake Trout is one of the most rapacious of our fishes and will devour almost anything, though its principal food consists of Herrings, young Whitefish, and other soft-finned fishes. It frequents deep waters and is usually taken near the bottom. The spawning season varies somewhat according to locality. In Lake Superior it commences early in October, while in other lakes it is deferred until November, and continues into December. The spawning grounds are on the reefs of honeycomb rock in from ten to one hundred feet of water.

There is a great difference of opinion as to its value as a game fish. Some anglers consider it affords a great deal of sport; others have no regard for it. I agree with the latter, having always found it a heavy, lumpish fish, with no fight in it. Commercially, however, it is of great importance, being always in demand and furnishes an excellent article of food.

The variety Siscowet (C. n. siscowet) differs from the common Lake Trout in having a deeper body, which is covered with a thicker skin, beneath which is a great development of fatty tissue. The scales are somewhat larger and the colour usually paler. It is most frequently taken in Lake Superior, though examples are sometimes found in Lakes Huron and Erie.

\section{Genus SALVELINUS. (Charrs.)}

Body moderately elongate; mouth large or small; teeth of jaws, palatines, and tongue essentially as in Salmo, the hyoid patch present or not; vomer boat-shaped, the shaft much depressed, without raised crest, with teeth on the head of the bone and none on the shaft; scales very small, two hundred to two hundred and fifty in a lengthwise series; fins moderate, the caudal forked in the young, truncate in some species in the adult; sexual peculiarities not strongly marked, the males with the premaxillaries enlarged and a fleshy projection at the tip of the lower jaw. Colouration dark, with round crimson spots, the lower fins sometimes with marginal bands of black, reddish and pale.

The species of this genus are by far the most active and handsome of the Trout; and live in the coldest, clearest and most secluded waters. Some of them occasionally descend to the sea, where they lose their variegated colours and become nearly plain and silvery.

\section{(73) Brook Trout.}

\section{(Salvelinus fontinalis.)}

The Brook Trout varies very much in the shape of the body, which is sometimes short and deep and sometimes long and thin. Head large, snout somewhat obtuse; mouth large; eye large, somewhat above axis of the body; caudal fin slightly lunate in the adult, forked in the young: adipose fin small and stout. 


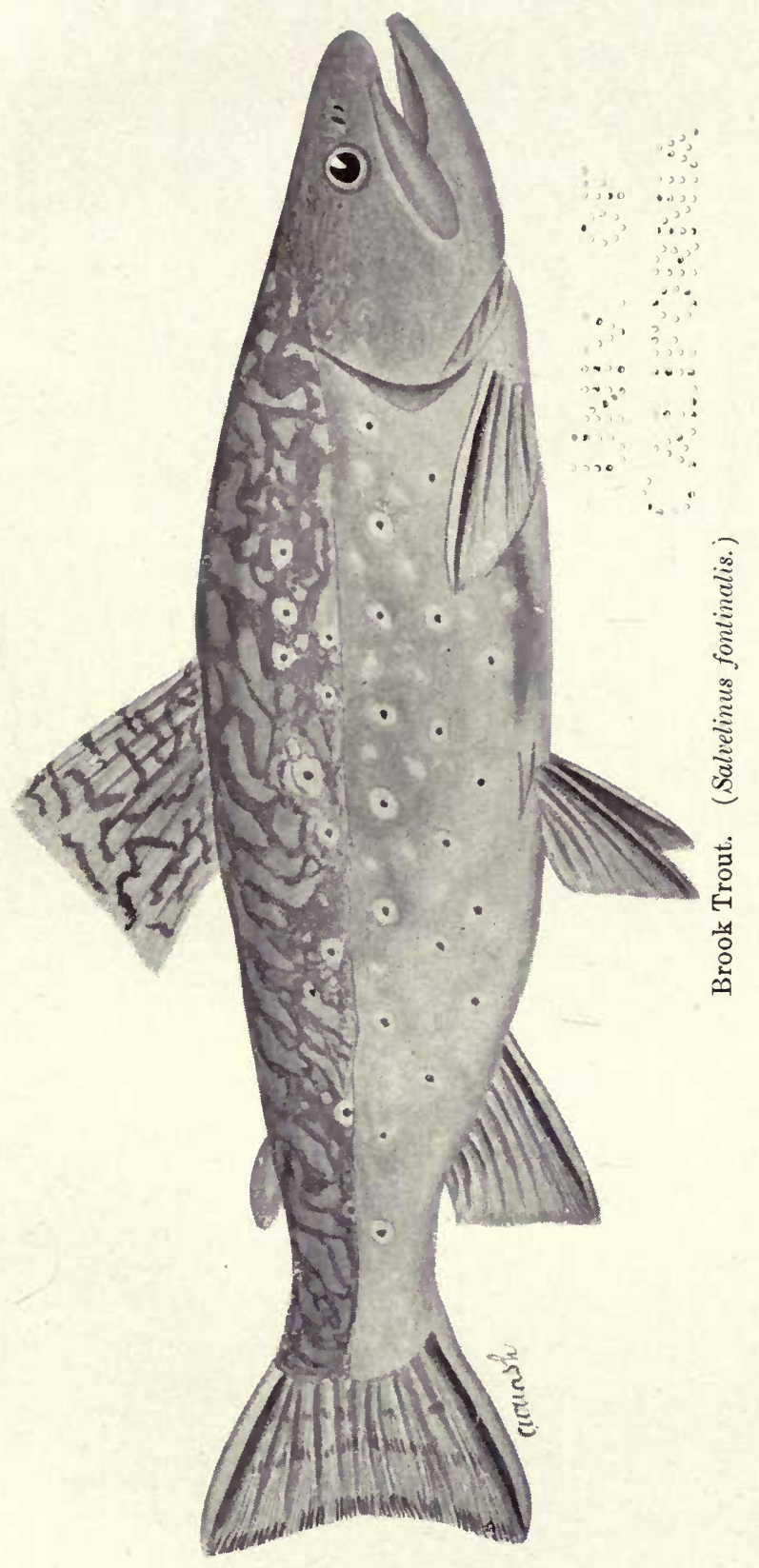




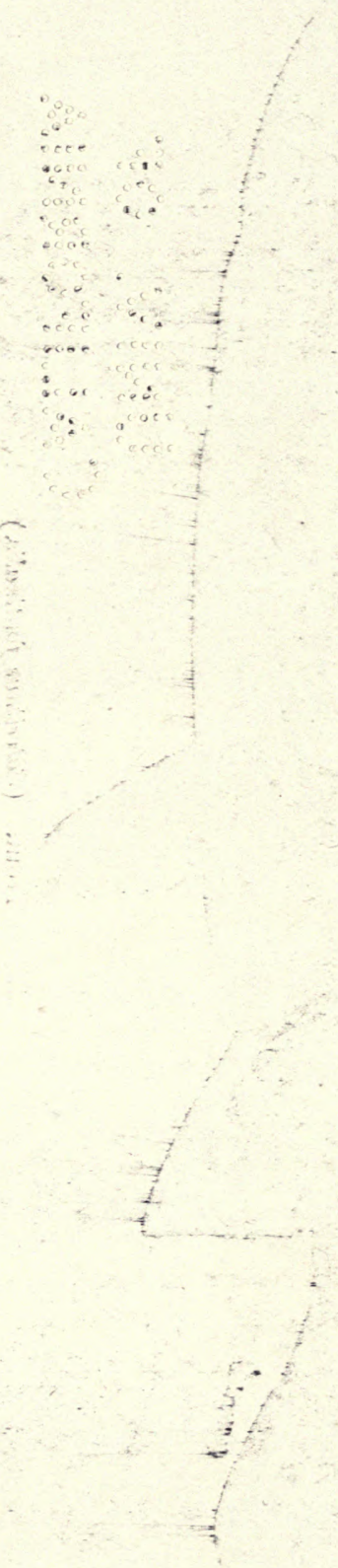


D., $10 ;$ A., 9. Scales on lateral line, 225 to 235 .

The colouration is highly variable with age and locality. Upper parts usually grayish, much mottled or barred with dark olive or black without spots; on the sides numerous pale brownish blotches encircle small scarlet spots. Dorsal and caudal fins mottled with darker; lower fins dusky with a creamy white band anteriorly followed by a black streak; belly of the male often more or less red; sea run fish are often plain bright silvery.

Brook Trout were formerly found in all the clear spring streams, and lakes fed by them, throughout the Province, but of late years, owing to the pollution of our waters and excessive fishing, its range is restricted to the unsettled districts, and except where it is artificially propagated and preserved it has ceased to exist in southern Ontario. As a game and food fish it is unexcelled, and angling for it is one of the most fascinating of outdoor sports. The size attained by this fish depends largely upon its habitat and food. In small streams it may mature at a length of six or eight inches and a weight of only a few ounces, while in large bodies of water, with an abundant food supply, they will reach eighteen inches or more in length and a weight of from six to eight pounds. In Lake Nepigon and some of the rivers of that famous district very large fish are still commonly taken.

In the cool days of late autumn the Brook Trout run up to the head waters of the streams and there on the gravelly shallows deposit their ova; the spawning season extending from September in the north to December in the south. The number of eggs produced depends upon the age and size of the fish. Yearlings (that is, fish in their second year) will produce from fifty to two hundred and fifty ova, while a large fish may produce as many as fifteen hundred. The eggs are about three-sixteenths of an inch in diameter and of a warm orange colour. The period of hatching depends upon the temperature of the water, ranging from thirty-two days in water at $54^{\circ}$ to one hundred and sixty-five days in water at $37^{\circ}$.

In the early part of the summer Trout frequent the ripples and shallower parts of the streams, but as the temperature rises and hot weathe: sets in they retire to the deeper pools or the vicinity of cold springs, wher they remain until the return of autumn starts them up stream again.

Though commonly called Brook Trout, our fish is really a Charr and is closely allied to, if not identical with, the famous Charr of North Britain and the continent of Europe.

\section{Order HAPL.OMI. (Pike-like Fishes.)}

Soft-rayed fishes with the mesocoracoid wanting; the coracoids normally developed, and the post-temporal normally attached to the cranium. Parietal bones separated by the supraoccipital. Symplectic present. Opercular bones well developed. Anterior vertebræ unmodified. Scapular arch joined to the cranium by a post-temporal. Hypocoracoid and hypercoracoid separate with developed actinosts. Pharyngeal bones distinct, the superior directed forward, three or four in number, the inferior not 
falciform. No interclavicles. Mouth with teeth. Air bladder with a distinct duct. Ventral fins abdominal, rarely wanting; pectoral fins placed low; dorsal fin more or less posterior, the first ray occasionally stiffened and spine-like; no adipose fin. Head usually covered with scales, like those on the body. Species chiefly inhabiting fresh water.

\section{FAMILY UMBRIDÆ. (Mud Minnows.)}

Body oblong, broad anteriorly, compressed behind. Head large, flattened above. Mouth moderate, with bands of villiform or cardiform teeth on premaxillaries, lower jaw, vomer, and palatines; premaxillaries not protractile; lateral margin of upper jaw, formed by the broad, short, maxillaries, which are toothless and without distinct supplemental bone; lower jaw the longer. Gill openings wide, the membranes scarcely connected; gill rakers little developed; branchiostegals six to eight. Scales moderate, cycloid, covering head and body; lateral line wanting. Dorsal fin moderate, posterior, in advance of anal; ventrals small, close to anal; pectorals inserted low; caudal fin rounded. Stomach without blind sac; no pyloric cæca; pseudobranchiæ hidden, glandular; air bladder simple. Oviparous fishes, the sexes similar. Carnivorous fishes of small size, living in mud, or among weeds, at the bottom of clear, sluggish streams and ponds; extremely tenacious of life.

\section{Genus UMBRA. (Mudfishes.)}

Body oblong, covered with cycloid scales of moderate size, without radiating striæ; no lateral line; head shortish, little depressed; eye rather small; cleft of mouth moderate; ventral fins six-rayed, below or slightly in front of dorsal; anal fin much shorter than dorsal; pectorals rather narrow, rounded, placed low, with twelve to fifteen rays, which are much articulated; caudal rounded; preopercle and preorbital with mucous pores; branchiostegals six; gill rakers rather short, thick. Size small.

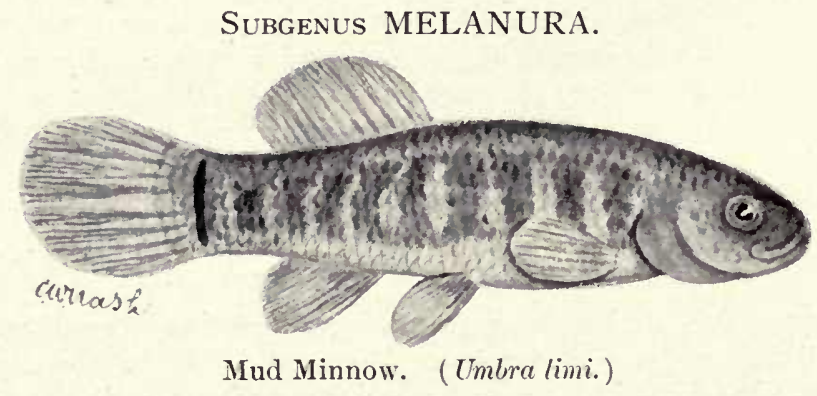

(74) Mud Minnow. Dogfish.

(Umbra limi.)

Body comparatively short and stout. Head rather large, flattened above. Ventral fins slightly before dorsal; anal much smaller than dorsal. 
D., I4; A., 9; V., 6; scales on lateral line 35 , in transverse series 15 .

Colour, dull olive green, with about fourteen narrow pale bars (faint in young), a black bar at the base of the caudal.

Common and generally distributed in muddy streams and inlets. The name is said to be derived from a habit this fish has of burrowing into the mud when the water evaporates from the ditches and ponds it frequents. It is seldom seen in clear water, preferring to hide at all times under stones or among weeds. It reaches a length of about four inches.

\section{Family LUCIID $\nRightarrow$. (PIKes.)}

Body elongate, not elevated, more or less compressed posteriorly, hroad anteriorly. Head long, the snout prolonged and depressed. Mouth very large, its cleft forming about half the length of the head; lower jaw the longer; upper jaw not protractile, most of its margin formed by the maxillaries, which are quite long and provided with a supplemental bone; premaxillaries, vomer and palatines, with broad bands of strong cardiform teeth which are more or less movable; lower jaw with strong teeth of different sizes; tongue with a band of small teeth. Head naked above; cheeks and opercles more or less scaly; gill openings very wide; gill membranes separate, free from the isthmus ; gill rakers tubercle-like, toothed; branchiostegals twelve to twenty. Scales small; lateral line weak, obsolete in young specimens, developed in the adult. Dorsal posterior, opposite and similar to anal; caudal fin emarginate; pectoral fins small, inserted low; ventrals rather posterior; vent normal; no adipose fin; no barbels; stomach not crecal, without pyloric appendages; pseudobranchiæ glandular, hidden; air bladder simple. Basis cranii double. Fishes of moderate or large size.

\section{Genus LUCiUs. (Pikes.)}

The genus Lucius is subdivided into three groups, distinguished by their size, scaling, and colouration. In the first group are three species of small Pike (commonly called by the Americans Pickerel), in which the cheeks and opercles are entirely scaly, the colour is greenish, usually with dark reticulations and the largest species reaches a length of about two feet. To this group the subgeneric name Kenoza is applied. Only one of these species has come under my observation in this Province, and it is probably very rare here.

In the subgenus Lucius we have only the Common Pike (also called Pickerel by our American neighbors), the typical species of the genus, which has the cheeks fully scaled and the lower half of the opercles naked. The sides are pale spotted, on a darker ground, and it grows to a much larger size than any of the species of the Kenoza group.

The subgenus Mascalongus contains only the Mascalonge, the largest member of the family. In this species the lower half of the cheeks as well as of the opercles is scaleless, and the scales are smaller than in those of the other groups. 


\section{Subgenus KENOZA.}

\section{(75) Green Pike.}

(Lucius reticulatus.)

Body long and slender; caudal peduncle slender, its depth little more than one-third of greatest depth of body. Snout long and pointed. Caudal deeply forked.

D., I4 to I5; A., I3 to I4. Scales on lateral line about 125. The cheeks and opercles are completely scaled.

Colour, green of various shades, sometimes very dark; sides (often with a golden lustre), marked with many dark lines and streaks which are mostly horizontal and by their junction with one another produce a reticulated appearance. A dark band below the eye. Fins plain.

This small Pike does not seem to be at all common in our waters. I have taken a few in the neighbourhood of Toronto, but have not met with it elsewhere. It should be found in suitable places in Lakes Erie and Ontario. Its usual haunts are weedy streams, ponds and bays, where it lies in wait for the fish, frogs, and other living creatures upon which it preys. It is said under favourable circumstances to attain a length of two feet and a weight of eight pounds, but those I have seen were never more than half that size. As a food fish it is not generally appreciated, for its flesh seems to have absorbed too strong a flavour of the weeds among which it lives.

\section{Subgenus LUCIUS.}

\section{(76) Common Pike. Northern Pike.}

(Lucius lucius.)

Body elongate, but stout and well proportioned; head long, with well produced snout; caudal peduncle nearly equal to one-half depth of body. Eye nearly median. Mouth very large and strongly toothed; the tongue, roof of mouth, pharynx and gill arches bristle, with teeth in cardlike bands, giving the fish extraordinary power in holding its prey. The dorsal and anal fins are near the caudal. Ventral fin midway between tip of snout and end of caudal fin.

D., 16 to 20 ; A., 16 to 17 . Scales on lateral side about 125 . Cheeks entirely scaly; upper part of opercle scaly, the lower half bare.

General colour greenish gray, with many white or yellowish spots, somewhat arranged in rows; dorsal, anal and caudal fins with roundish or oblong black spots. Naked part of the opercle bounded by a whitish streak.

Common and generally distributed throughout the Province in all waters where there are sufficient weeds to afford it shelter.

The Pike is one of the most voracious of our fishes, feeding upon any form of animal life which it is able to overpower. Under favourable cir- 


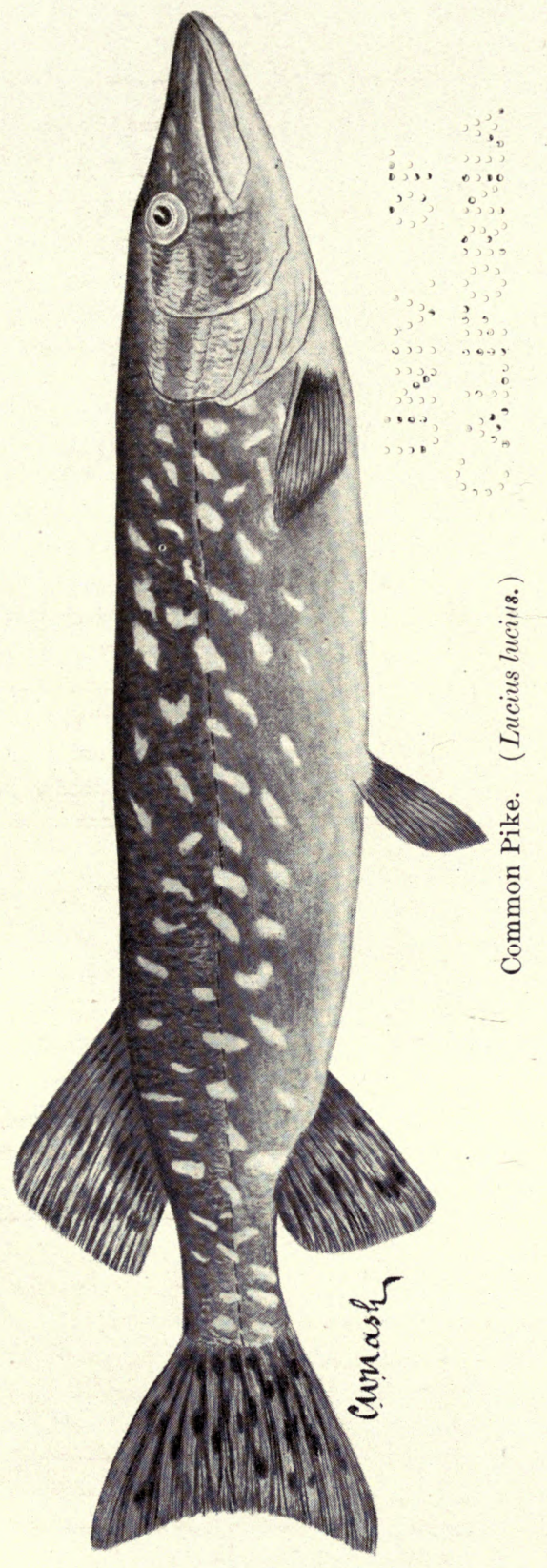




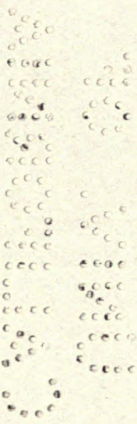


cumstances it attains a large size, specimens of more than forty pounds weight having frequently been captured in Europe. In Canada it does not grow so large, though in Manitoba, where it is commonly known as "Jackfish." Fish of twenty pounds were not very uncommon a few years ago. In Ontario it is so constantly pursued that it does not now get a chance to attain its full dimensions, and Pike of over ten pounds' weight are becoming rare.

Spawning takes place in early spring, as soon as the ice breaks up; the fish running up on to rush beds or grassy shallows for that purpose. The females are very prolific, one weighing thirty-two pounds was estimated by the late Professor Buckland to contain 595,ooo ova.

Many anglers profess to look upon the Pike with contempt and treat its claim to be considered a game fish with derision. This is because it is usually taken by them in the summer months, when it is not in good condition. It is then soft in flesh and weedy in flavour, but in the autumn, after the weeds have died down, it is a different fish; then its flesh is firm and good and its fighting powers will tax the angler's skill to the utmost.

\section{Subgenus MASCALONGUS.}

\section{(77) Mascalonge. Lunge.}

(Lucius masquinongy.)

Body elongate, though stout; caudal peduncle short and slender. Head large; eye nearly in the middle of length of head. Mouth very large, the maxilla extending to below the hind margin of the eye. The teeth are as in the Pike, but even more formidable. Dorsal and anal fins far back. Caudal deeply forked. D., I7 ; A., I 5 to I6. Scales on lateral line, 150 ; cheek and opercle scaled above, but both naked on their lower half.

Colour, dark grey, greenish or brownish, always darker on the back, lighter on the sides. Belly white or whitish. The fins usually have dusky spots or blotches, the lower fins and caudal are sometimes reddish. The body markings vary a great deal. In the young the upper half of the body is covered, with small round black spots, which usually change their shape or disappear as the fish grow older. In mature fish the spots are more diffuse, sometimes enlarging to an inch or more in diameter, or by coalescing, form vertical broad bands, while in others there are no distinct dark markings. All these various markings are found in fish from the same locality. The majority of Lunge in our waters are either unmarked or show faint bars, the spotted form being the most uncommon.

The distribution of Mascalonge in our waters is somewhat irregular. It is found in the St. Lawrence about the Thousand Islands, in the waters of the Trent Valley, Lake Scugog, Lake Simcoe, and many of our inland lakes, but I have no record of its occurrence in any of the Great Lakes 
except Lake liric and the Ceorgian Bay, where it is quite common. Its northern range is not yet clearly defined, but does not probably extend beyond the height of land.

Spawning takes place early in spring, soon after the ice goes out, in shallow water about the reed beds. Here the females deposit a large number of eggs, from which the fry hatch in from fifteen to thirty days, according to temperature.

The "Lunge" is, except at pairing time, a solitary fish, usually lying concealed among aquatic plants at the sicles of channels, or in open lakes, bencath shelving rocks, from whence it darts upon every living thing anfortunate enough to come within its reach and small enough to become its prey.

When taken in the atutumn, at which time it is in high condition, its flesli is lirm, flaky and of good flavour, and its fighting qualities at their very best. In summer it affords comparatively little sport and its flesh is apt to taste weedy.

Under fatvourable circumstanees Mascallonge attain an immense size, fish of eighty to one hundred pounds' weight having been taken in various places. We do not often sec such monsters now, but specimens ranging from thirty to fifty pounds are caiptured every season.

\section{ГАмแ. P(JiCIIII)A:. (THะ KH,H1sHEs.)}

Body oblong, or moderately elongate, compressed behind, depressed forward, covered with rather large eycloid seales, which are adherent and regularly arranged, Lateral line wanting or represented by a few imperfeet pores. Head scaly at least above. Mouth terminal, small, the lower jaw usually projecting; margin of the upper jaw formed by the premaxillarics only; premaxillaries strong, extremely protractilc. Tecth incisorlike or villiform, sometimes present on the vomer, but usually in the jaws only; lower pharyngeals separate, with cardiform or rarely molar tecth; third upper plaryngeal enlarged, the fourth wanting or united to the third. Gill membranes somewhat connected, free from isthmus; gill rakers very short, thick. Brancliostegals four to six. Pseudobranchia none. Dorsal fin single, inserted posteriorly, of soft rays only, rarely with a single spine, or rudinentary spinous dorsal; catudal lin not forked; ventral fins abelominal, rarely wanting; pectoral fins inserted low; no adipose fin. Stomach siphonal, without pyloric appendages, Air bladder simple, often wanting. Basis cranii simple. Sexes usually unlike, the fins being largest in the males, but in some species the females are much the larger.

\section{GiNUS FiUNDULUS. (KH,111s11\%s.)}

Body rather elongate, little elevated, compressed behind; mouth moderate, the lower jaw projecting; jaws each with two or more series of 



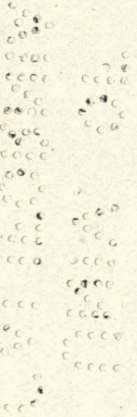


pointed teeth, usually forming a narrow band, bones of the mandible firmly united; scales moderate; gill opening not restricted above, the opercle with its margin not adnate to shoulder girdle; preopercle, preorbital, and mandible with nucous pores; dorsal and anal fins similar, smail, or rather large, the dorsal inserted either in front of, above, is behind, the front of anal; ventrals well developed; air bladder present; sexes differing in colour, size and development of the fins, the anal fin in the male normal; intestinal canal short; first superior pharyngeal without teeth, second with teeth, third and fourth coössified, with teeth. Species very numerous, mostly American, inhabiting fresh waters and arms of the sea. They are oviparous.

\section{Subgends FONTINUS.}

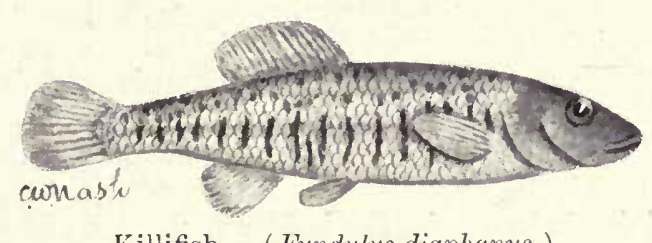

Killifish. (Fundulus diaphanus.)

(78) Killifish. Fresh-water Killy.

(Fundulus diaphanus.)

Body rather slender; head flat above; mouth very protractile, small, its width somewhat greater than the length of the lower jaw. Fins low, the dorsal midway between the tip of the snout and the root of the caudal. The anal is wholly under the dorsal. Caudal large, convex behind.

D., I4; A., I2. Scales on lateral line, 46.

The females are olivaceous, sides silvery, with fifteen to twenty-five narrow dark crossbands; fins pale. In the breeding season the males are olive with about twenty pearly white cross bars.

Abundant in bays and shallow inlets near the lakes; usually found quite close to the shore line, associated in small shoals. A fairly good bait fish, though not as attractive as the bright shiners and chub.

This species attains a length of about four inches.

\section{Order HEMIBRANCHII. (The Half-gills.)}

Interclavicles developed. Gills pectinate. Post-temporal simple, not furcate; supraclavicle quite small. Superior pharyngeal bones reduced in

$S$ F. 
number, the bones of the gill arches also reduced except in Gasterosteidæ; inferior pharyngeals present, not united. Ventral fins abdominal or subabdominal, joined to the interclavicle, or else detached from it through partial atrophy of the shoulder girdle. Mouth bounded above by premaxillaries only; shoulder girdle simple in structure. Basis of cranium simple and without tube; four anterior vertebræ more or less elongate; snout usually more or less produced, the small mouth at its end.

\section{Family GaSterosteid Æ. (The Sticklebacks.)}

Body more or less fusiform, somewhat compressed, tapering behind to a slender caudal peduncle. Head moderate, the anterior part not greatly produced, but all the bones of the suspensory apparatus somewhat lengthened. Mouth moderate, with the cleft oblique, the lower jaw prominent; maxillary bent at right angles and overlapping the premaxillary at corner of mouth. Teeth sharp, even, in a narrow band in each jaw; no teeth on vomer or palatines; premaxillaries protractile. Preorbital rather broad; suborbital plate large, often covering the anterior part of the cheeks, forming a connection with the preopercle. Branchiostegals three. Gill membranes broadly joined, free from the isthmus, or not; gill rakers moderate or rather long. Opercles unarmed. Skin naked or with vertically oblong bony plates; no true scales. Dorsal fin preceded by two or more free spines; anal similar to soft dorsal, with a single spine; ventral fins subabdominal, consisting of a stout spine and one or two rudimentary rays. Middle or sides of belly shielded by the pubic bones. Pectorals rather short, unusually far behind the gill opening, preceded by a quadrate naked area which is covered with shining skin. Caudal fin narrow, usually lunate. Air bladder simple; a few pyloric cæca. Vertebræ, thirty to thirtyfive; anterior vertebræ little enlarged. Small fishes inhabiting the fresh waters and arms of the sea, noted for their pugnacity. fishes.

They are exceedingly destructive of the spawn and fry of larger

Most of the Sticklebacks build elaborate nests, which the male fish defends with much spirit. The species are extremely variable, being apparently readily affected by changes in surroundings.

\section{Genus EUCAliA. (Brook Sticklebacks.)}

Fresh-water Sticklebacks, feebly armed,the skin not mailed, the dorsal spines few and nondivergent; the gill membranes forming a free fold across the isthmus; pubic bones fully united. One species known. 


\section{(79) Brook Stickleback.}

(Eucalia inconstans.)

Body elongated, rather stout; the caudal peduncle without keel; skin entirely smooth. The ventral spines and pubic bones are very small, the latter concealed under the skin. The thoracic processes covered by the skin, slender and widely separated. Dorsal spines short, nearly equal in length, placed in a straight line, the anterior spines shortest. Ventral spines small and serrated.

D. III. to IV., I., 10; A. I., 10.

Males in the breeding season jet black, tinged with coppery red. The females and young are greenish, variegated with darker.

Common in small streams and ponds, where it secretes itself among water plants, ready at any moment to attack any small fish which approaches its lair, or to dart upon passing insects small enough to become its prey.

This species is a nest builder and is particularly vigorous in the defence of its eggs or young. It grows to a length of two and a-half inches.

\section{Genus Pygosteus. (Many-spined Sticklebacks.)}

This genus is characterized by the presence of nine to eleven divergent spines and by the weakness of its innominate bones. As in Eucalia, the gill membranes form a broad fold across the isthmus.

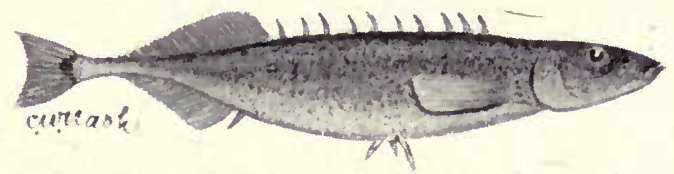

Ten-spined Stickleback. (Pygosteus pungitius.)

\section{(8o) Ten-spined Stickleback.}

(Pygosteus pungitius.)

Body elongate, somewhat compressed. - The dorsal spines are all in the same line in a furrow, but they diverge so as to form a zigzag series. Pubic bone weak, lanceolate, not serrate; ventral spines slender, pungent, finely serrate above and below; gill membranes free from isthmus behind; gill rakers long and slender; caudal fin lunate, slightly emarginate.

D. IX. to XI., I., 9; A. I., 8. 
Colour brownish above, punctulate and irregularly barred with black. Tail keeled. Length about three inches. In the breeding season the male becomes rosy beneath.

Not particularly common in this Province, but generally distributed through the region of the Great Lakes. It is said to be abundant in the streams of the Atlantic coast and in the fresh waters of the Arctic regions.

\section{Genus GASTEROSTEUS.}

Sticklebacks with the innominate bones coalescent on the median line of the belly, behind and between the ventral fins, forming a triangular or lanceolate plate. Gill membranes united to the isthmus; tail slender, and usually keeled; skin variously covered with bony plates; dorsal spines strong, with nondivergent bases. Species numerous and highly variable, those found in the sea usually with the body completely mailed, the fresh and brackish water forms variously mailed, or even altogether naked.

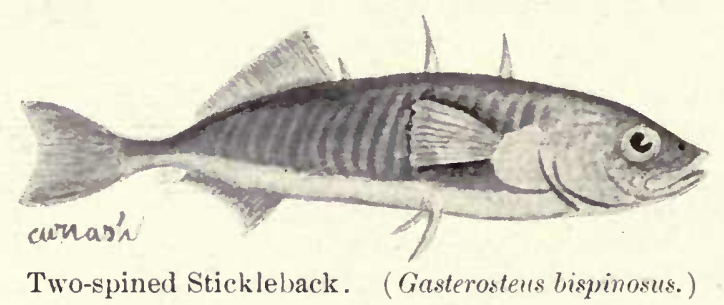

\section{(81) Two=spined Stickleback.}

(Gasterosteus bispinosus.)

Body fusiform, moderately elongate and compressed; caudal peduncle short, slender and distinctly keeled. The sides are covered with about thirty-three bony plates. The processes from the shoulder girdle cover the breast except a small naked area between them. At the base of each dorsal spine is a large rough bony plate to which the spine is hinged in such a way that it may be fixed and immovable at the will of the fish. The pelvic bone is lanceolate. The spines are all closely serrated, those in front of the anal and soft dorsal smallest. At the base of the ventral spine there is a cusp.

D. II. I., I I to I 3 ; A. I., 9 .

Colour, greenish olive, lighter on the sides, lower parts silvery. Gill covers silvery, with dusky markings; iris silvery; pupil black; fins pale. 
In the breeding season the male is brilliant bluish or greenish above, with indistinct dark bars and generally bright red below. Length in our waters about three inches.

Rather common in spring in the streams and inlets of Lake Ontario, but I have not found it elsewhere. Its centre of abundance in America is along the North Atlantic coast, where it is found in all the streams from New Jersey to Labrador. The male of this species constructs a rather elaborate nest, of sand, pieces of sticks, weeds, etc., in which the female deposits her ova. When this is done the male stands guard over it, fanning with his fins to promote circulation of the water, only leaving his post to dart at an intruder or secure some small insect for food.

\section{Order ACANTHOPTERI. (The Spiny-rayed Fishes.)}

Anterior vertebræ unmodified and without ossicula auditus; no mesocoracoid and no interclavicles so far as known. Border of mouth. formed by premaxillary; maxillary normally distinct from it and always present, but sometimes coössified with it. Gills laminated. Shoulder girdle attached to the skull by a post temporal, which is normally furcate and usually not coössified with the skull. Hypercoracoid and hypocoracoid distinct, ossified, the former usually perforate. Pharyngeals well developed, the lower rarely united, the third upper pharyngeal largest, the fourth often wanting. Pectoral actinosts always present, opercular apparatus complete; gill openings in advance of the pectorals; pectoral fins above the plane of the abdomen; ventral fins more or less anterior, normally attached by the pelvis to the shoulder girdle, typically with one spine and five rays, sometimes wanting, sometimes without spine or with many rays, or otherwise modified. Anterior rays of dorsal and anal typically simple or spinous, but all the fin rays often articulate. Air bladder typically without duct in the adult. Scales various, typically ctenoid; lateral line usually running high.

\section{Suborder SALMOPERC $Æ$. (The Trout Perches.)}

Ventrals abdominal, each with a short simple ray; dorsal with two simple rays or spines; anal with one or two; mouth formed as in Percoij fishes, the simple toothless maxillary not forming part of its border. Adipose fin present. Scales ctenoid; head naked; pseudobranchiæ present. Air bladder apparently with a rudimentary duct. Stomach siphonal, with a few cæca. Shoulder girdle without mesocoracoid, apparently of the normal percoid type; vertebræ about thirty-five. 


\section{Family PERCopsid A: (Trout Perches.)}

Body moderately elongate, somewhat compressed, the caudal peduncle long and slender. Head conical, pointed, naked. Mouth small, horizontal ; maxillary short, narrow, without supplemental bone, not reaching to the large eye; margin of upper jaw formed by premaxillaries alone, which are short and not protractile. Teeth very small, villiform on premaxillaries and lower jaw only. Tongue short, adherent. Gill membranes separate; free from the isthmus. Pseudobranchiæ present. Branchiostegals six. Gill rakers short, tubercle-like. Opercle with entire edges. Lower limb of the preopercle well developed, the angle nearly a right angle, its inner edge with a raised crest, its outer edge crenulate or with a few spines. Bones of the head cavernous; cranium with a raised crest, which does not extend to the occiput. Scales moderate, rather firm, adherent, their edges strongly ctenoid. Lateral line continuous. Dorsal short, median with two spines, slender or stout; ventrals anterior, just in front of the dorsal, with one rudimentary spine and about eight rays; pectorals narrow, placed rather high; anal small, with one or two spines; caudal forked; adipose fin present, small. Vertebræ about thirty-five. First superior pharyngobranchial without teeth ; second, third, and fourth separate, with teeth. Lower pharyngeals separate. Stomach siphonal, with about ten well developed pyloric cæca. Ova unusually large, not falling into the abdominal cavity before exclusion. Air bladder present, with a band of connective tissue which is apparently with a rudimentary duct. Small fishes of the fresh waters of the cooler parts of America. This group is one of special interest, as it combines with ordinary salmonoid characters, the structure of the head and mouth of a Percoid.

\section{Genus PERCopsis. (Trout Perches.)}

Body rather slender, pellucid, covered with rather thin scales; dorsal fin with two slender spines or simple rays; anal with one; scales roughest posteriorly; lateral line developed; preopercle entire or very nearly so.

\section{(82) Trout Perch. Sand Roller.}

(Percopsis guttatus.)

Body rather long, moderately compressed, covered with thin ctenoid scales: head scaleless and without barbels; gill openings wide; opercles well developed; gill rakers short, tubercular; skull highly cavernous; mouth small, the margin of the upper jaw formed by the short non-protractile intermaxillaries; no supplemental maxillary bone; small villiform 
teeth on the intermaxillaries and mandible. Tongue short, not free at tip. Six branchiostegals. Lateral line continuous. The first dorsal over middle of body. Adipose fin small ; caudal long, forked; pectorals narrow, placed high. The stomach is siphonal, with numerous pyloric cæca. The eggs are moderately large and are excluded through an oviduct. Air bladder present. Lower jaw included.

D., I I ; A., 8. Scales on lateral line, 47 to $5^{\circ}$.

Colour, upper parts pale olivaceous or brown, marked with rounded dark spots, made up of minute dots; a silvery median stripe, becoming obsolete in front; peritoneum silvery. Attains a length of about eight inches.

I have not found this fish common anywhere in Ontario, though it ranges all through the Great Lakas and their tributaries north to Hudson Bay. It is perhaps more abundant in the Moira River, near Belleville, than elsewhere in our Province, and is said to be frequently taken in the clear cold waters of Lake Superior.

It is too small to be of much value to anglers, though it takes bait readily and is used for food by those who care for such small game. To the naturalist it is interesting, combining as it does the characteristics of the Salmon and some of the Perches.

It spawns in the spring, running up the streams for that purpose.

\section{Suborder XENARCHI. (The Pirate Perches.)}

Structure of mouth and skeleton, so far as known, essentially that of the Percoid fishes. Dorsal fin single, with a few small spines; ventrals thoracic, with a small spine, and more than five soft rays. Air bladder large and adherent. Intestinal canal ending at the throat in the adult, the vent variously posterior in the young. Vertebræ, twenty-nine.

\section{Family APHREDoderid $Æ$. (Pirate Perches.)}

Body oblong, elevated at the base of the dorsal, compressed behind; the head thick and depressed; the profile concave. Caudal peduncle thick; mouth moderate, somewhat oblique, the lower jaw projecting; maxillary reaching to anterior border of the eye. Teeth in villiform bands on jaws, vomer, palatines and pterygoids. Premaxillaries not protractile; maxillaries small, without evident supplemental bone. Preopercle and preorbital with their free edges sharply serrate; opercle with a spine. Bones of skull somewhat cavernous. Sides of the head scaly. Lower pharyngeals narrow, separate, with villiform teeth. Gill membranes slightly 
joined to the isthmus anteriorly. Gill rakers tubercle-like, dentate. Pseudobranchiæ obsolete. Gills four, a small slit behind the fourth. Branchiostegals six. Scales moderate, strongly ctenoid, adherent. Lateral line imperfect or wanting. Vent always anterior, its position varying with age, from just behind the ventral fins in the young to below the preopercle in the adult. Dorsal fin single, median, high, with but three or four spines, which are rapidly graduated, the first being very short. Anal small, with two slender spines; ventral fins thoracic, with a very short spine, the number of soft rays usually seven; caudal fin rounded behind. Air bladder simple, large, adherent to the walls of the abdomen. Pyloric cæca, about twelve.

\section{Genus APHredoderus. (Pirate Perches.)}

The characters of the genus are included above.

\section{(83) Pirate Perch.}

(Aphredoderus sayanus.)

Body moderately stout, oblong, somewhat compressed posteriorly. Scales ctenoid. Dorsal fin continuous, its origin much in advance of the middle of the total length; the anterior spines much the shortest. Mouth large for the size of the fish, the lower jaw somewhat longer than the upper ; the maxilla reaches to front of eye; jaws, vomer and palatine bones with villiform bands of teeth. Lateral line wanting. Caudal rounded.

D. III., I I ; A. II., 6. Scales on lateral line, 48 to $5^{8}$.

Colour, variable, sometimes olivaceous, at other times dark brown with numerous dark punctulations; a dark bar at the base of the caudal followed by a light one. It reaches about four inches in length.

I include this species, though there are no Ontario records of its occurrence here known to me. It should, however, be found in the streams of the Niagara district and at the western end of Lake Erie. It frequents sluggish streams and ponds in which aquatic weeds abound, and is remarkable because the position of the vent varies with age. In the young it is behind the ventrals, while in the adult it is in the throat.

\section{Suborder PERCESOCES.}

Ventral fins abdominal, each of one spine and five rays; branchial arches well developed, the bones all present except the fourth superior branchihyal. Third superior pharyngeal much enlarged; lower pharyngeals distinct. Scales cycloid. Pectorals elevated, about on a level with the upper posterior angle of operculum; spinous dorsal usually present. 


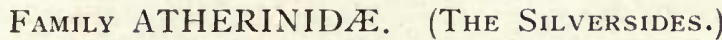

Body rather elongate, somewhat compressed, covered with scales of moderate or small size, which are usually, but not always, cycloid. No lateral line; some scales often with rudimentary mucous tubes. Cleft of the mouth moderate. Teeth small, on jaws and sometimes on vomer and palatines, rarely wanting. Premaxillaries protractile or not. Opercular bones without spines or serrature. Gill openings wide, the gill membranes not connected, free from the isthmus; gills four, a slit behind the fourth. Pseudobranchiæ present; gill rakers usually long and slender. Branchiostegals five or six. Dorsal fins two, well separated; the first of three to eight slender flexible spines, the second of soft rays; anal with a weak spine, similar to the soft dorsal, but usually larger; ventrals small, abdominal, not far back, of one small spine and five soft rays; pectorals moderate, inserted high. Air bladder present. No pyloric cæca. Vertebræ numerous, usually about $23+23=46$; third and fourth superior pharyngeals coöossified with teeth. All the species have a silvery band along the side; this is sometimes underlaid by black pigment.

\section{Genus LABIDESTHES.}

Jaws prolonged, both of which are produced into a short depressed beak. The scales are small, their edges entire.

\section{(84) Silversides. Skipjack.}

(Labidesthes śicculus.)

Body very slender, elongate. Caudal deeply forked.

D. IV. I., I I; A. I., 23. Scales on lateral line, 75.

Colour, green, the fish in life translucent, upper parts dotted. A very distinct silvery lateral band edged above with lead colour; cheeks silvery. Length, about four inches.

This species is found in Lake Ontario, Lake Erie, and the Detroit River, and may be generally distributed throughout the Great Lake region. As a food fish for larger species it is important.

\section{Group PERCoideA. (The Perch-tike Fisiles.)}

A group of fishes of diverse habits and forms, but on the whole representing better than any other the typical Acanthopterygian fish. The group is incapable of concise definition, or in general, of any definition at all; still most of its members are definitely related to each other, and bear in one way or another a resemblance to the typical form, the Perch, or more strictly to its marine relatives, the Sea Bass or Serranidæ. The following analysis gives most of the common characters of the group: 
Body usually oblong, covered with scales, which are typically ctenoid, not smooth or spinous, and of moderate size. Lateral line typically present and concurrent with the back. Head usually compressed laterally and with the cheeks and opercles scaly. Mouth various, usually terminal and with lateral cleft, the teeth various, but typically pointed, arranged in bands on the jaws, vomer, and palatine bones; gill rakers usually sharp, stoutish, armed with teeth; lower pharyngeal almost always separate, usually armed with cardiform teeth; third upper pharyngeal moderately enlarged, elongate, not articulated to the cranium, the fourth typically present; gills four, and a slit behind the fourth; gill membranes free from the isthmus, and usually not connected with each other; pseudobranchia typically well developed. Branchiostegals few, usually six or seven. No bony stay connecting the suborbital chain to the preopercle. Opcrcular bones all well developed, normal in position, the preopercle typically serrate. No cranial spines. Dorsal fin variously developed, but always with some spines in front, these typically stiff and sharp. Anal fin typically short, usually with three spines, sometimes with a larger number, sometimes with none; caudal fin various, usually lunate; pectoral fins well developed, inserted high; ventral fins always present, thoracic, separate, almost always with one spine and five rays. Air bladder usually present, without air duct in the adult; simple and generally adherent to the walls of the abdomen. Stomach crecal, with pyloric appendages, the intestines short in most species, long in the herbivorous forms. Vertebral column well developed, none of the vertebræ specially modified; shoulder girdle normally developed, the post temporal bifurcate, attached to the skull, but not coössified with it; none of the epipleural bones attached to the centre of the vertebræ; coracoids normal; the hypercoracoid always with a median foramen, the basal bones of the pectoral (actinosts or pterygials) normally developed, three or four in number, hour-glass shaped, longer than broad; premaxillary forming the border of the mouth usually protractile; bones of the mandible distinct.

\section{Family Centrarchid}

Body more or less shortened and compressed; the regions above and below the axis of the body nearly equally developed and corresponding to each other, and the pseudobranchiæ imperfect. Head compressed. Mouth terminal, large or small. Teeth in villiform bands, the outer slightly enlarged, without canines; teeth present on premaxillaries, lower jaw and vomer, and usually on palatines, also sometimes on tongue, pterygoids and hyoid. Premaxillaries protractile; maxillary with a supplemental bone in the large-mouthed forms, sometimes minute or obsolete in others. Preopercle entire or somewhat serrate; opercle ending in two flat points, or prolonged in a black flap at the angle. Preorbital short and deep; first suborbital narrow; the maxillary not slipping under its edge. Nostrils, 
two on each side. Gills four, a slit behind the fourth. Pseudobranchiæ small, almost glandular, nearly or quite covered by skin. Gill membranes separate, free from the isthmus. Branchiostegals six, rarely seven. Gill rakers variously formed, armed with small teeth, lower pharyngeal bones separate, their teeth conic or sometimes paved. Cheeks and opercles scaly; body fully scaled, the scales usually strongly ctenoid, rarely cycloid; lateral line present, usually complete. Dorsal fins confluent, the spines six to thirteen in number (usually ten), depressible in a shallow groove; anal spines three to nine. Intestinal canal short. Pyloric cæca five to ten. Vertebræ, twenty-eight to thirty-five. Entopterygoid present. Precaudal or abdominal vertebræ with transverse processes from the third or fourth to the last; ribs all but the last two to four, sessile, inserted on the centrum behind the transverse processes. Frontals with a pair of large muciferous channels which converge posteriorly or are confluent with a transverse channel connecting the post frontals, their posterior openings close together on the median line in front of the supraoccipital crest. Colouration usually brilliant. Sexes similar; changes with age often great. Fresh water fishes of North America; forming one of the most characteristic features of our fish fauna. Most of the species build nests which they defend with much courage. All are carnivorous, voracious and gamy. All are valued as food, their importance being in direct proportion to the size which they attain.

\section{Genus POMOXIS. (Grass Bass.)}

Body more or less elongate, strongly compressed, the snout projecting ; mouth large, oblique; maxillary broad, with a well developed supplemental bone; teeth on vomer, palatines, entopterygoids and tongue; lower pharyngeals narrow, with sharp teeth; gill rakers long and slender, numerous; opercle emarginate; preopercle and preorbital finely serrated; scales large, feebly ctenoid; fins large, the anal larger than dorsal, of six spines and about seventeen rays; dorsal with six to eight graduated spines, the spinous dorsal shorter than the soft part; caudal fin emarginate; pectorals rounded or obtusely pointed, with fifteen or sixteen rays, the upper longest; ventrals close together, each with a strong spine; branchiostegals seven; lateral line complete, the tubes straight and extending at least on the anterior half of the exposed surface of the scale; posterior processes of the premaxillaries not extending to the frontals; supraoccipital and parietal crest very strong, produced forward on the frontals to between the orbits; vertebræ, $18+15=33$.

\section{(85) Crappie. Silver Bass.}

(Pomoxis annularis.)

Body oblong, but more elongated than the next, the depth two-fifths of the total length; much compressed. Mouth oblique, larger than in the 
next; profile more or less $\mathrm{S}$ shaped; head depressed, snout projecting; upper jaw nearly one half the length of head, the maxilla reaching slightly beyond the middle of the eye.

D. VI., 16; A. VI., 17. Scales, 7-45-13.

Colour, clear silvery olive, the sides mottled with dark greenish blotches; on the upper part of the body are traces of narrow vertical bars. The dorsal and caudal fins are mottled, but the anal is usually plain. Attains a length of about twelve inches and a weight of one pound.

This species ranges from the Great Lakes southward. It occurs rarely in Lake Erie and possibly also in Lake Ontario. In appearance the Crappie and the Speckled Bass are very much alike, the best distinguishing marks between them being the more elongated form of the Crappie, the possession of only six spines in the dorsal, and the nearly uniform plain whitish colour of the anal.

In its habits it closely resembles the next and more familiar species.

(86) Speckled Bass. Calico Bass.

(Pomoxis sparoides.)

Body oblong, compressed, its depth about one-half the length without the tail; head about one-third length. Mouth very oblique and smaller than in the Crappie; the profile comparatively even; fins very high.

D. VII., I5; A. VI., I7 to 18 . Scales on iateral line, 4 I to 42 .

Colour, silvery olive mottled with clear olive green, the dark markings gathered in small irregular bunches and covering the whole body; vertical fins with dark olive reticulations, surrounding pale spots; anal rnarked like the dorsal; a dusky opercular spot. Under favourable circumstances it attains a length of ten or twelve inches and a weight of one pound or rather more.

The Speckled Bass is found in the waters of this Province from Quebec to Lake Huron. It frequents ponds, lagoons, and sluggish streams, where there is an abundance of aquatic vegetation, under which it lies in wait for the insects, crustaceans and small fish upon which it feeds. It spawns in the early summer and is said to scoop out a nesting place in the sand in the same manner as the Sunfishes and Black Bass. This I have never seen, though I have been very familiar with the species for nearly forty years.

As a food and game fish it stands high in the estimation of anglers, though it is not a very persistent fighter. Being gregarious and congregating in schools, under overhanging weeds and such like places, it may be captured in great numbers when a favorite haunt is discovered.

This species readily adapts itself to life in artificial ponds and is worthy of much more attention from fish culturists than it has heretofore received, for when taken from clear water it is one of the best thable fish we have. 


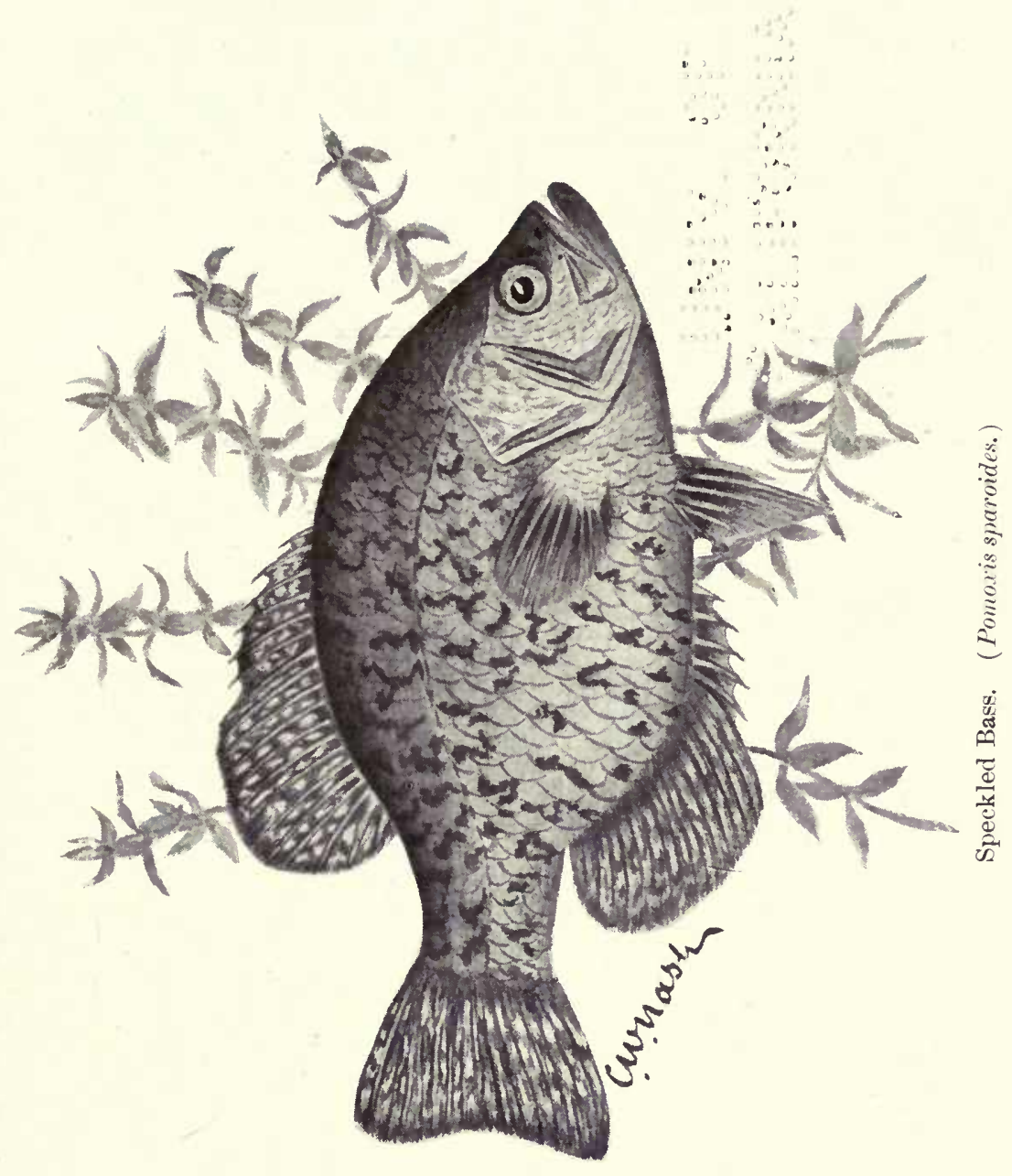




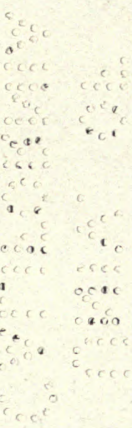


It feeds principally towards evening, and the best bait for it is a bright, lively shiner or chub.

\section{Genus AMBLOPLiteS. (Rock Bass.)}

Body oblong, moderately elevated, compressed; mouth large, the broad maxillary with a well developed supplemental bone, lower jaw projecting; teeth on vomer, palatines, tongue, entopterygoids and ectopterygoids, lingual teeth in a single patch, pharyngeal teeth sharp; branchiostegals six; opercle ending in two flat points; preopercle serrate at its angle, other membrane bones chiefly entire; gill rakers rather long and strong, dentate, less than ten in number, developed only on the lower part of the arch; scales large, somewhat ctenoid; lateral line complete, the tubes occupying at least the anterior half of the surface of the scale; dorsal fin much more developed than the anal fin, with ten or eleven rather low spines; anal spines normally six; pectorals obtusely pointed with fourteen or fifteen rays, the upper longest; caudal fin emarginate.

\section{(87) Rock Bass.}

\section{(Ambloplites rupestris.)}

Body robust, oblong; caudal peduncle stout, almost as deep as long. Dorsal profile rather steep, strongly concave over eye. Eye large. Mouth large, the maxillary reaching to vertical from posterior end of pupil. The heavy lower jaw projects slightly. The opercle ends in two flat points; preopercle serrated at its angle. Gill rakers long and strong, less than ten in number; six branchiostegals; scales large, those on the cheeks in about eight rows; caudal rather deeply emarginate. The lateral line is complete, placed high on body and follows the contour of the back.

D. XI., I 1; A. VI., I I. Scales, 5-46-I4.

Colour olive green, with a brassy tinge and much dark mottling; the young are pale or yellowish, irregularly barred and blotched with black; adults with a dark spot at the base of each scale, these spots sometimes forming interrupted black stripes; a dark spot on the opercle; soft dorsal, anal, and caudal fins with dark mottlings; iris golden overlaid with crimson.

The Rock Bass grows to a length of about a foot and a weight of a pound and a half, though such large specimens are not often seen now. It ranges throughout the whole of this Province, and is said to occur in Manitoba, but I did not find it there.

Its usual haunts are dark holes in streams or lakes, where aquatic vegetation flourishes, and it is often to be found in considerable numbers about docks or timber work, which shades the water. From these places it emerges towards nightfall and roams about in search of the insects, crustaceans and small fish which form its food. When taken from clear, cold water, it is esteemed as a table fish, and when fished for with light 
tackle will afford fair sport to the angler. To the schoolboy the Rock Bass is a "joy forever," for it rarely refuses a bait even when offered upon the coarsest tackle, and a good string will always reward his efforts if he strikes the right places.

The spawning season is in May or June, when a shallow nest is scooped out on some gravelly or sandy bar, in which the eggs are deposited. Over this the parent fish watch with unremitting care until the young are hatched.

\section{Genus CHANOBRYTTUS. (Warmouths.)}

This genus has the general form and dentition of Amboplites, with the convex opercle, ten dorsal and three anal spines of Lepomis. Preopercle entire; branchiostegals six; caudal fin emarginate; scales weakly ctenoid; vertebræ, $13+\mathrm{I} 6=29$; posterior processes of the premaxillaries extending nearly to the frontals; frontals posteriorly with a transverse ridge connecting the parietal and stupraoccipital crest, which are very strong.

\section{(88) Warmouth.}

(Chænobryttus gulosus.)

Body heavy and deep, but more elongate than in our common Sunfishes; head rather long; eye moderate; mouth large, the maxillary reaching to below hind margin of eye; gill rakers eight or nine, besides some rudiments; opercular spot about as large as the eye. The dorsal begins further back than the pectoral, its spines low.

D. X., 9 to Io; A. III., 8 to 9. Scales, 6-40 to $46-12$.

Colour very variable, usually olive green, clouded with darker; a dusky spot on each scale more or less distinct; vertical fins mottled with dusky; a faint spot on last rays of dorsal bordered by paler; three oblique dusky bars radiating from eye; belly yellowish.

It reaches a length of about ten inches.

I am under the impression that some years ago this fish was found in the marsh at Toronto, and also near Hamilton, but of late no specimens have been obtainable. It should occur in Lake Erie and will probably be found in the Niagara district. Its centre of abundance is, however, south of this Province.

\section{Genus APOMOTIS.}

This genus is very close to Lepomis, from which it differs only in the development of the supplementary maxillary bone, which becomes rudimentary or wanting in the adult of Lepomis. The mouth is largest in the species in which this bone is best developed. Lower pharyngeals narrow, 


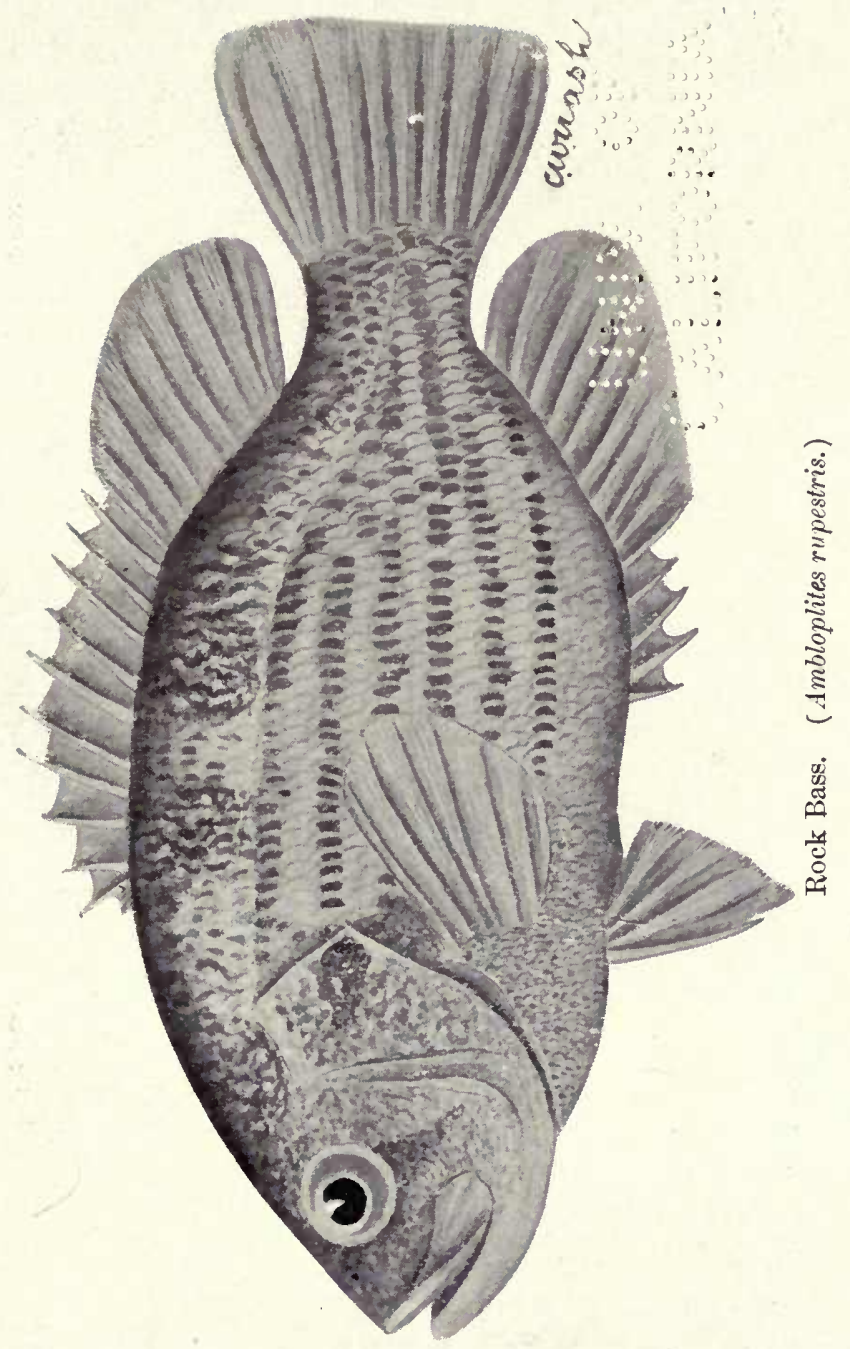

9 F. 

with acute teeth; gill rakers well developed, long and stiff ; pectoral bluntish, shorter than head; scales moderate, 43 to 50 . Habits similar to those of the species of Lepomis.

\section{(89) Green Sunfish.}

\section{(Apomotis cyanellus.)}

Body oblong, the back not elevated; mouth large, the maxillary reaching nearly to middle of eye; dorsal spines low ; opercular flap short, with pale margin.

D. X., I ; I A. III., Io. Scales, 7-47-14.

Colour, green with a brassy lustre, each scale with a blue spot and gilded edging; fins largely blue; anal edged with orange; iris red; cheeks with blue stripes.

I have no Ontario records of this fish, but as it will probably be found in Lake Erie, it is mentioned here. Its centre of abundance is said to be the Ohio basin.

It is too small to be of value as a game fish, seldom attaining a greater length than six or eight inches.

\section{Genus LEPOMIS. (Sunfishes.)}

Body oblong or ovate, more or less compressed, the back in the adult somewhat elevated; mouth moderate or small, the jaws about equal ; maxillary narrow, the supplemental bone reduced to a mere rudiment, or altogether wanting; teeth on vomer and usually on palatines, none on tongue or pterygoids, lower pharyngeals narrow, the teeth spherical or paved, all or nearly all sharp, few or none of them conical; gill rakers mostly short; preoperculum entire; operculum ending behind in a convex flap, black in colour, which in some species becomes greatly developed with age; branchiostegals six; scales moderate; dorsal fin continuous, with ten spines; anal with three spines; caudal fin emarginate; pectorals long or short. Colouration brilliant, but evanescent. A large genus, and one in which it is rather difficult to distinguish species. The form of body, development of ear flap and height of spines vary with age and condition, while the general appearance and the numbers of fin rays and scales are essentially the same in all.

\section{Subgenus LEPOMIS.}

(9o) Blue Sunfish.

(Lepomis pallidus.)

Body deep, elliptical, its greatest depth at the ventrals, one-half of the total length without the caudal ; caudal peduncle short and deep. Head one-third of the total length without caudal. Snout short, obtuse and 
oblique, the interorbital space slightly convex. Mouth small, oblique, the maxilla not greatly expanded behind, reaching to below the front of the eye. Scales on the cheeks in five rows. The gill rakers are short and stout, about fifteen developed on the first arch. No supplemental maxillary bone. No palatine teeth. Caudal fin notched, its middie rays threefourths as long as the outer. The lateral line follows the curve of the back.

D. X., II; A. III., Io. Scales, 7-41-15.

Colour, rich greenish olive on back, becoming paler on sides; top of head dark greenish; opercles and cheek bluish; opercular flap rich velvety black, a small whitish spot above near its base; side with three or four broad darker greenish bars; fins all greenish, the pectoral palest; a large black blotch on last rays of dorsal, a similar one on anal; the dark bars become obsolete in the adult; no blue stripes on cheek; no red on fins; old individuals often with the belly coppery red or brassy.

This is the largest of the Sunfishes, reaching sometimes a length of twelve inches or rather more, and a weight of about a pound. Thic linest specimens I ever saw were taken from the Rideau a few miles above Kingston. It occurs abundantly in some parts of Lakes Ontario and Erie and their tributaries, but I have not heard of it in the northwestern part of the Province.

As a table fish it is highly esteemed, and, in proportion to its size, possesses greater fighting qualities than any fresh-water fish we have.

\section{Gexls EUPOMOTIS.}

Very closely related to Lepomis, differing only in the blunter and more pavement-like teeth of the lower pharyngeal bones. These bones are, in the typical species, broad and concave, specially in the adult. There is considerable variation among the species, and it is possible that this division can not be maintained. Most of the species have long pectoral fins, the suplemental maxillary lost or very much reduced, and the opercular flap always with an orange patch on its lower posterior part. Gill rakers various, usually short.

\section{Subgenus EUPOMOTIS.}

\section{(91) Yellow Sunfish. Pumpkin Seed.}

(Eupomotis gibbosus.)

Body much compressed, nearly ovate, its depth one-half the total length without caudal; caudal peduncle short and compressed. Head moderately large, one-third of the total length without caudal. Snout short and depressed, the interorbital space nearly flat. Mouth small and oblique, the maxilla not much expanded behind and reaching to below front of 


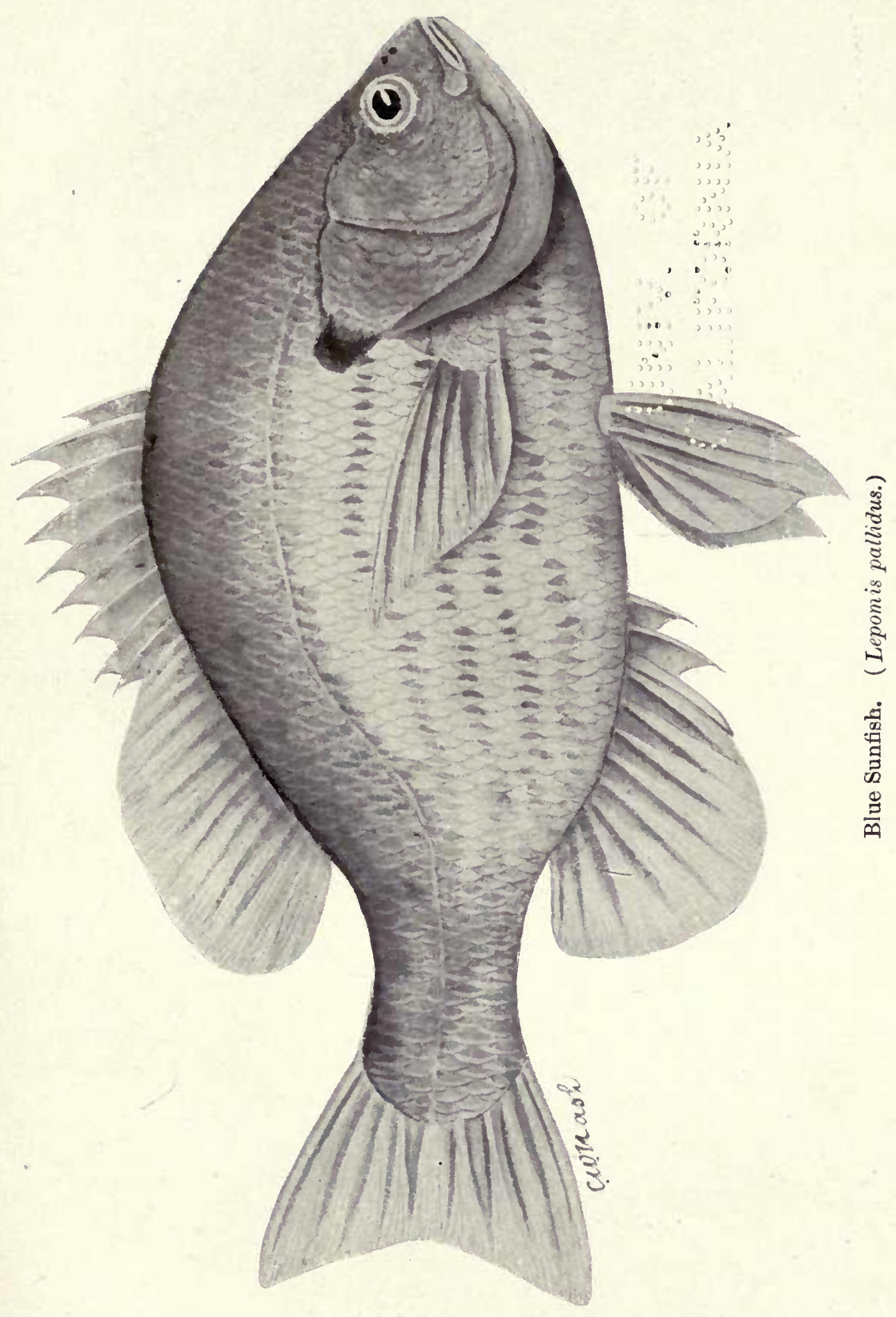




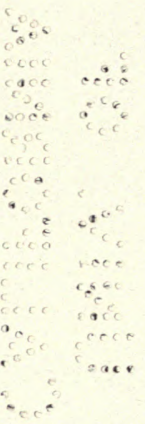


eye. Scales on the cheeks in four rows. The opercular spot short, less than two-thirds diameter of the eye, with a whitish margin behind. Gill rakers very short, moderately stout, Io or II developed on the first arch. Caudal emarginate, its middle rays four-fifths as long as the outer. The lateral line follows the curve of the back.

D. X., I 2 ; A. III., го. Scales, 6-42-13.

Colour: In life one of the most beautiful of fresh-water fishes; greenish olive above, shaded with bluish, the sides spotted and blotched with orange; belly orange yellow; cheeks orange with wavy blue streaks; lower fins orange; sides profusely mottled with orange. Opercular flap black, the lower posterior part bright scarlet. Grows to a length of eight inches and a weight of half a pound.

The common Sunfish is very abundant in all the waters of southern and central Ontario, ranging to Lake Huron, which is probably its limit for there are as yet no records of it from the Lake Superior region.

Though rather too small to be of value as a game or food fish, yet it affords great sport to the younger anglers, and is by no means to be despised upon the table.

The spawning season is in May and June, the fish resorting to shallow water, where the ova are deposited in nests scooped out in the sand or mud, by the action of the fins. Over these the males keep guard until the young are hatched, in the meantime driving off all intruders and promoting circulation of the water by fanning with ventral fins and tail.

\section{Genus Micropterus. (Black Bass.)}

Body oblong, compressed, the back not much elevated; head oblong, conical; mouth very large, oblique, the broad maxillary reaching nearly to or beyond the posterior margin of the eye, its supplemental bone well developed; lower jaw prominent; teeth on jaws, vomer and palatines in broad villiform bands, the inner depressible, usually no teeth on the tongue; preopercle entirc, operculum ending in two flat points without cartilaginous flap; branchiostegals normally six; gill rakers long and slender; scales rather small, weakly ctenoid; lateral line complete, the tubes straight, occupying the anterior half of each scale; dorsal fin divided by a deep notch, the spines low and rather feeble, ten in number; anal spines three, the anal fin much smaller than the dorsal; pectorals obtusely pointed, the upper rays longest, ventrals close together below the pectorals, caudal fin emarginate; posterior processes of the premaxillaries not extending to the frontals; frontals posteriorly with a transverse ridge connecting the parietal and supraoccipital crests, which are very strong.

Two species; among the most important of game fishes. 


\section{(92) Small=mouthed Black Bass. Black Bass.}

(Micropterus dolomieu.)

Body ovate-fusiform, becoming deeper with age; mouth large, but smaller than in the large-mouthed black bass; maxillary ending considerably in front of posterior border of orbit, except in very old examples; scales on cheek minute; those on body small; dorsal fin deeply notched, but less so than in the next species, the ninth spine being about half as long as the fifth and not much shorter than the tenth; soft dorsal and anal each scaly at the base.

D. X., I 3 to 15 ; A. III., io to 12 . Scales, II -72 to $85-25$. About 17 rows of scales on cheek.

Colour, dull golden green with bronze lustre, often blotched with darker, especially on head; young with darker spots along the sides, which tend to form short vertical bars, but never a dark lateral band; three bronze bands radiating from eye across cheek and opercles; a dusky spot on point of opercle; caudal fin yellowish at base, then black, with white tips; dorsal with bronze spots, its edge dusky. In some waters the fin markings are obsolete, but they are usua!ly conspicuous in the young. Adults sometimes have all these markings obliterated, the colour becoming a uniform dead green, without silvery lustre, the stripes on the head, however, remaining more or less distinct.

This Bass is found in greater or less abundance throughout the Province. It seems to prefer cool, clear waters, having a rocky or gravelly bottom, and ranges further north than its large-mouthed relative. As a game fish it is sought after by anglers in preference to any other, except, perhaps, the Salmon, and on the table is highly esteemed as food.

Spawning begins in May and ends early in July, the season being dependent largely upon the temperature of the water; incubation lasts from seven to fifteen days. The parent fish scoop out shallow nests in the sand or gravel to receive the eggs, which are then guarded assiduously until hatched.

The food of Black Bass consists chiefly of insects, crustaceans and small fish, but when hungry nothing that it can overpower comes amiss At the approach of winter it ceases to feed and lies dormant under logs, weeds, or rocks until the warmth of spring restores at the same time its energy and voracity.

Its maximum weight in our waters is about six pounds, but fish of this size are rare.

\section{(93) Large-mouthed Black Bass. Yellow Bass. Green Bass.}

(Micropterus salmoides.)

Body ovate-fusiform, becoming deeper with age, moderately compressed; head large; mouth very wide, the maxillary in adult reaching beyond the eye, shorter in the young ; scales on body comparatively large; gill rakers longer than gill fringes: dorsal fin very deeply notched, the spinous dorsal low, its fourth spine longest. 


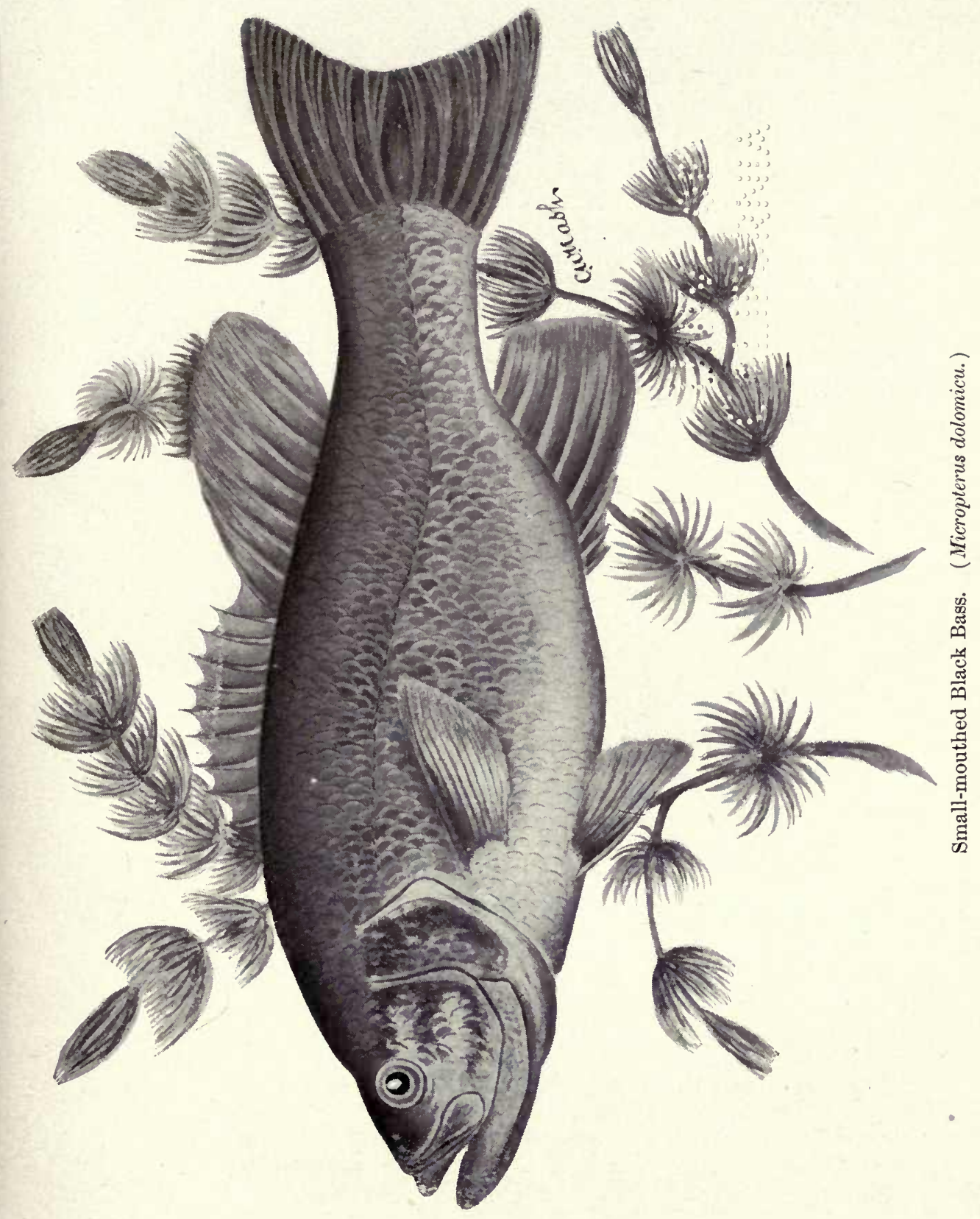




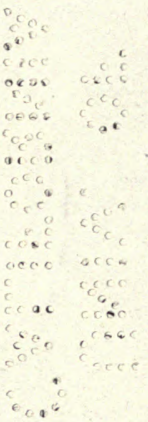




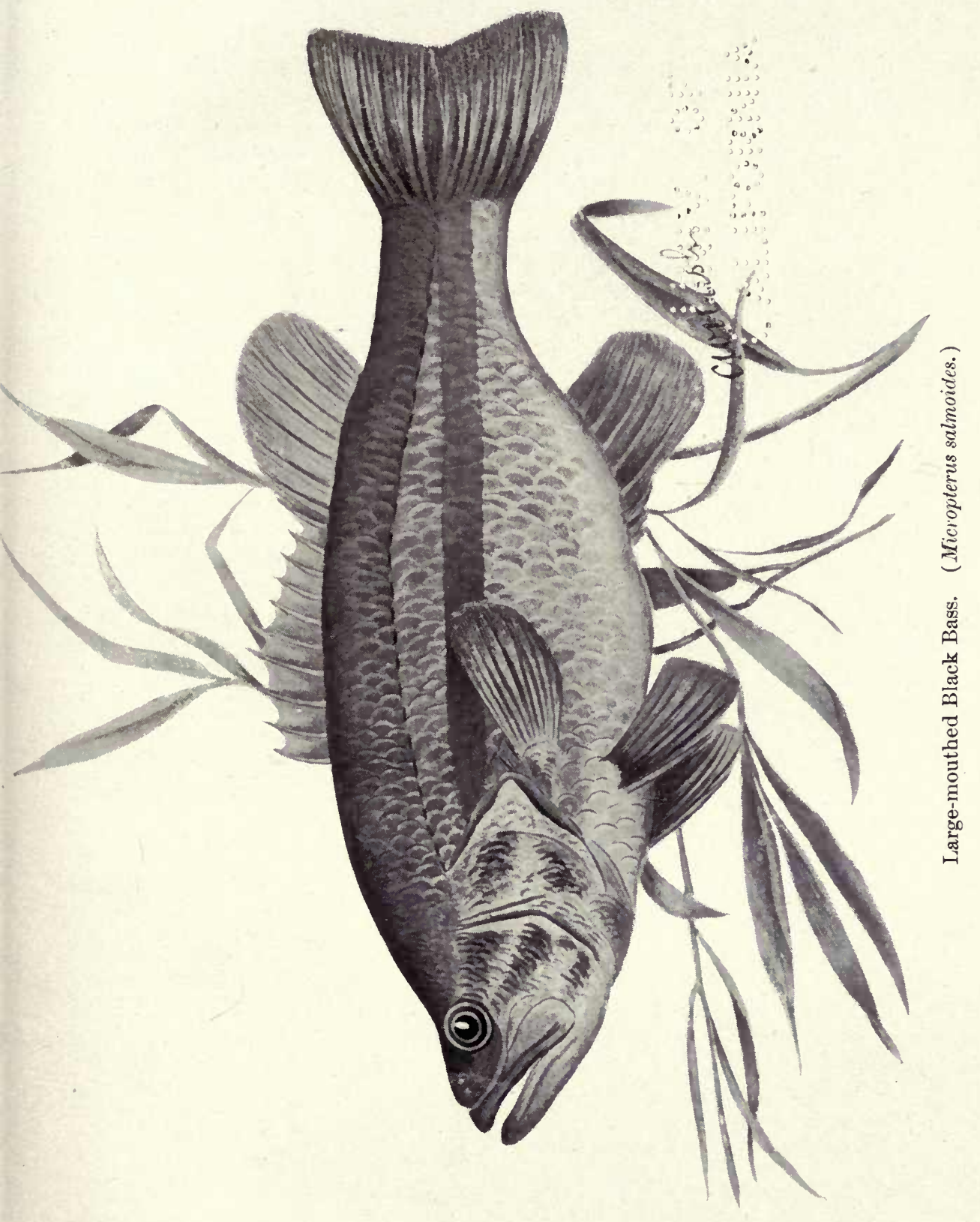



D. X., 12 or 13; A. III., 10 or I1. Scales, $7-65$ to $70-18$; ro or II rows of scales on cheek.

Colour, dark green above, sides and below greenish silvery; young with a blackish stripe along the side from opercle to middle of caudal fin. Three oblique dark stripes across the cheek and opercles; some dark spots above and below lateral line; caudal fin pale at base, then blackish, and whitish at tip; belly white. As the fish grows older the black lateral band breaks up and grows fainter and the colour becomes more and more uniform, pale dull green, the back being darker.

The maximum weight attained by this fish in our waters is about six pounds, further south it grows to a large size. It is generally distributed throughout the Province, being most abundant in waters having a mud bottom in which aquatic plants flourish. It scems able to adapt itself to running streams, and even to thrive in them, but in quiet lakes and bays it reaches the greatest size.

The spawning season begins in May and ends at the beginning of July. A nest is scooped out of the sand or mud, in which the adhesive eggs are deposited. These are guarded by the parent fish until hatched. Incubation lasts from one to two weeks, according to the temperature of the water, and the young bass, after emerging from the eggs, remain in the nest for about a week.

As the weather becomes cold this Bass seeks deep places, often hibernating under rocks, sunken logs, or in the mud. In the summer its favourite localities are under overhanging banks or in holes among weeds, where it lies in wait for the frogs, fish and crustaceans which constitute the greater part of its food.

\section{Famlly PERCid E. (The Perches.)}

Body more or less elongate, terete or compressed, covered more or less completely with rather small, ctenoid adherent scales. Dorsal and ventral outlines more or less unlike. Lateral line usually present, not extending on the caudal fin. Mouth terminal or inferior, small or large, the premaxillaries protractile or not; maxillaries large or small, without distinct supplemental bone. Jaws, vomer, and palatines with bands of teeth, which are usually villiform, but sometimes mixed with canines, occasionally the teeth on the vomer or palatines are absent. Head naked, or more or less scaly; preopercle entire or serrate; opercles usually ending in a flat spine. Branchiostegals six or seven. Gills four, a slit behind the fourth; gill membranes free or connected, not joined to the isthmus; gill rakers slender, toothed; pseudobranchiæ small, or glandular and concealed, or altogether wanting; lower pharyngeals separate, with sharp teeth. Anal papilla more or less developed. Fins generally large; two dorsals, the first of six to fifteen spines; anal fin with one or two spines, the usual number two. Ventrals 
thoracic I., 5; pectorals often very large; caudal, lunate, truncate or rounded. Air bladder small and adherent; often entirely wanting. Pyloric cæca few. No subocular lamina of the suborbitals; entopterygoid present. Anterior vertebræ without transverse processes; only the first pterygial or actinost usually in contact with the coracoid; sometimes a part of the second also. The posterior processes of the premaxillaries are short; the supraoccipital and parietal bones are short and confined to the back of the skull; parietal crests are absent, and the supraoccipital crest is very short, not extending to the anterior extremity of the bone or even absent.

\section{Genus Stizostedion. (Pickerel. Pike Perches.)}

Body elongate, fusiform, the back broad; head subconical, long, cheeks, opercles and top of head more or less scaly; mouth large, the jaws about equal; premaxillaries protractile, little movable; teeth in villiform bands, the jaws and palatines with long, sharp canines; gill rakers slender, strong; gill membranes separate; preopercle serrated, the serræ below turned forward; opercle with one or more spines, terminations of radiating striæ, dorsal fins well separated, the first with twelve to fifteen spines, the second with seventeen to twenty-one soft rays, last dorsal spine not erectile, bound down by membranes; anal spines two, slender, closely appressed to the soft rays, which are rather long, eleven to fourteen in number; ventral fins well separated, the space between them equal to their base, ventral spine slender, closely appressed to the soft rays; scales small, strongly ctenoid; lateral line continuous; branchiostegals seven; pseudobranchiæ well developed; pyloric cæca three to seven. Large carnivorous fishes of the fresh waters of North America.

\section{Subgenus STIZOSTEDION.}

(94) Yellow Pickerel. Pike-Perch. Dore.

(Stizostedion vitreum.)

Body long and moderately deep, its depth varying with age; head long; eye rather large; lower jaw slightly projecting; the maxilla reaching beyond the pupil. The soft dorsal is nearly as long as the spinous.

D. XIII., I., 2 I ; A. II., I 2 to r 3 . Scales, ro-9o-19.

Colour, olivaceous mottled with brassy; sides of the head vermiculated; the dorsals, caudal and pectoral with bands; those of the dorsals and caudal not continuous; sides with about seven oblique dark bands, differing in direction; a jet black blotch on the membrane behind the last spine of the dorsal.

The Yellow Pickerel is found in all the larger bodies of water throughout Ontario, more particularly in the Great Lakes and the rivers falling into them. Its spawning time is in early spring, when it runs on to gravelly or sandy bars or even up rivers for the purpose of depositing its 


$$
\$
$$





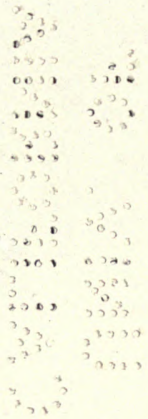

$10 \mathrm{~F}$. 


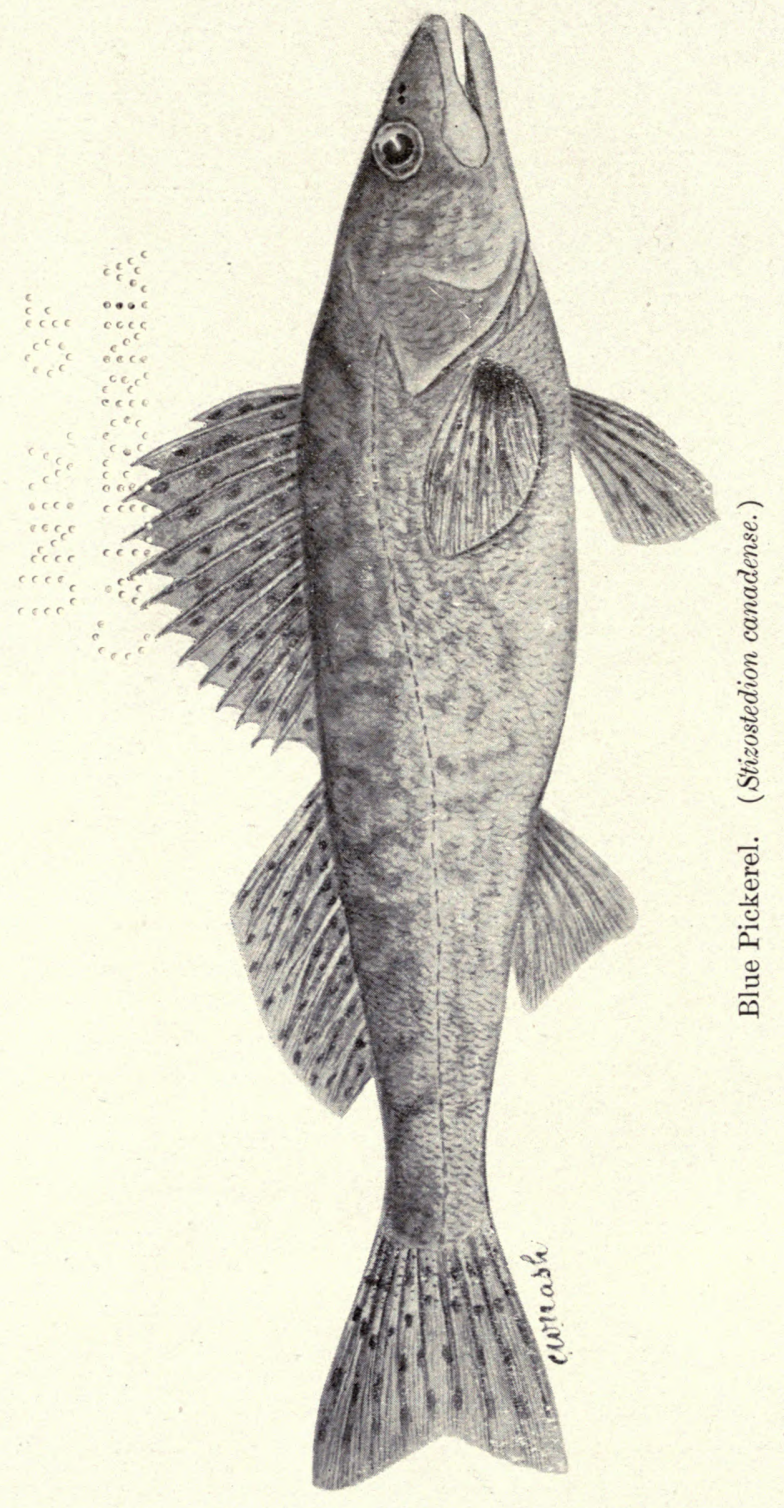


ova. As soon as the water becomes warm they work off into deep water, where they remain during the hot months.

As it is a deep-water fish it does not often afford much sport for the angler, but as a commercial and food fish it is decidedly the best we have in the lakes, its flesh being firm, white, flaky and well flavored.

Under favourable circumstances this species reaches a large slze, specimens of 'twenty-five pounds' weight having been recorded. These are, however, very rare, and a ten-pound fish is now considered a very good one. It is extremely voracious, feeding upon such other fish as it can overpower, and the insects and crustaceans found in its haunts. In Manitoba, where I found it abundant, frogs were the most attractive baits.

In the Lake Erie district and perhaps elsewhere, the young, if of a pale color, are known as "Blue Pickerel," as this form shows no structural differences, its identity with the Yellow Pickerel seems certain.

\section{Subgenus CYNOPERCA.}

\section{(95) Sand Pickerel. Blue Pickerel. Sauger.}

(Stizostedion canadense.)

Body elongate, more terete than in the preceding, the flesh more translucent; head depressed, pointed. Eye small; mouth smaller than in the last; the maxilla reaches to the hind margin of the eye.

D. XII. to XIII., I., I7 to 18 ; A. II., I2. Scales on lateral line, 92 to $98 ; 4$ to 7 pyloric cæca of unequal length; all of them shorter than the stomach.

Colour, olivaceous above; sides brassy, with black markings in the form of irregular blotches which are best defined under the soft dorsal. The spinous dorsal has several rows of round black spots on the membrane between the spines; no black blotch on the hind part of the spinous dorsal. Pectorals with a large dark blotch at base; soft dorsal with several rows of dark spots irregularly placed; caudal yellowish with dark spots forming interrupted bars.

This is a smaller fish than the last, rarely exceeding eighteen inches in length and a weight of two pounds. It is also less valued as a food fish, its flesh being softer and of inferior flavour.

The range and habits of this species are much the same as those of its congener and in proportion to its size it is equally destructive to small fish.

Two varieties have been described, viz., griseum and boreum, but it is doubtful if their distinctive characters are sufficiently permanent to entitle them to sub-specific rank. 


\section{Genus PERCA. (The True Perches.)}

Body oblong, somewhat compressed, the back elevated; cheeks scaiy, opercles mostly naked; the operculum armed with a single spine; preopercle and shoulder girdle serrated, preopercle with retrorse, hooked serrations below; mouth moderate, terminal; premaxillaries protractile; teeth in villiform bands on jaws, vomer, and palatines, no eanine teeth ; branchiostegals seven; gill membranes separate; pseudobranchiæ small, but perfect; no anal papilla; scales rather small, strongly etenoid, lateral line complete, the tubes straight and not extending to the extremity of the scale; dorsal fins entirely separate, the first of twelve to sixteen spines; anal fin with two slender spines, well separated from the soft rays; ventral spines well developed, the ventral fins near together; caudal emarginate; air bladder present; pyloric cæca, three.

\section{(96) Yellow Perch.}

(Perca flavescens.)

Body fusiform, moderately elongate, the back elevated, cheeks scaly; opercles mostly naked, striate; premaxillaries protractile, preorbital selrate; snout projecting, maxillary reaching middle of pupil; top of head rugose; gill rakers stout; caudal notched.

D. XV., II., I3; A. II., 8 . Scales, 7-57-13.

Colour on the back olivaceous, varying to greenish; sides golden yellow, with about six to eight broad dark bars which extend from back to below axis of body; lower fins largely red or orange, especially so in the spring; upper fins olivaceous. Like all fish, it varies greatly, the yellow is sometimes very bright, at other times quite pale, and the black bars are much deeper in some waters than in others.

This species reaches a length of ten or twelve inches and a weight of a pound or rather more. The largest I ever saw taken from our lakes weighed one pound and two ounces. It is one of the most abundant of our fishes and is found in all the lakes and streams of any size throughout the Province. As a food fish, if taken when the water is cool it is only excelled by the Yellow Pickerel. During the hot summer months the Perch of shallow, weedy waters become soft and lose their fine flavour. To anglers accustomed to Black Bass and Lunge it is rather an insignificant species, but it has this to recommend it, that it can be caught by anybody, with any sort of tackle, at all times of the year.

The Perch spawns in early spring and the eggs, which are very small, are enclosed in a long, narrow, translucent, strip of adhesive mucus.

\section{Genus PERCina. (Log Perches.)}

Body elongate, slightly compressed, covered with small ctenoid scales; lateral line continuous; ventral line with enlarged plates which fall 

off, leaving a naked strip; head depressed, rather pointed, the mouth being small and inferior, overlapped by a tapering, subtruncate, piglike snout; upper jaw not protractile, maxillary small, exposed; teeth on vomer and palatines; gill membranes scarcely connected; dorsal fin well separated, the first the larger, of thirteen to fifteen spines, the second dorsal rather longer than the anal, which has two spines, the first of which is usually the shorter; pectorals symmetric, rounded or bluntly pointed, their rays fourteen or fifteen, their spines moderate; ventral fins well separated, the interspace about equal to their base; air bladder and pseudobranchiæ present, rudimentary.

\section{(97) Log Perch.}

\section{(Percina caprodes.)}

Body long, slightly compressed; head long, with pointed stout, mouth small; the lower jaw not reaching near to tip of snout, and the maxilla not extending to the front of the eye. Scales on cheeks and gill covers, also on the space before the first dorsal; breast scaleless. A row of enlarged plates on the belly, which are sometimes deciduous. Fins moderately low and rather long.

D. XV., I5; A. II., 9. Scales in lateral line, 92.

Colour, greenish yellow, with about fifteen dark cross bands, extending from back to belly; alternating with those above the lateral line are fainter bars. Fins barred. A black spot at the base of the caudal.

This is the largest of the Darters, reaching a length of about eight inches. It is found throughout the Great Lake region in clear, rapid streams having a gravelly or rocky bottom. The variety next mentioned is probably the common form of Ontario.

\section{(98) Manitol Darter.}

(Percina caprodes zebra.)

Similar to the last, but nape always naked; lateral black bars short, not extending much above lateral line, these also more or less confluent, about twenty in number; a black caudal spot; dorsal and caudal mottled.

D. XV., I4; A. II., 10. Scales, 90.

This variety of $P$. caprodes is found in the rapid streams of the Great Lake region, and more particularly those falling into Lake Superior.

\section{Genus HADROPTERUS. (Black-Sided Darteks.)}

Body rather elongate, compressed or not; muth rather wide, terminal, the lower jaw included; the snout above not protruding beyond the premaxillaries, which are not protractile; tceth on vomer and usually on palatines also; gill membranes separate or more or less connected; scales small, ctenoid, covering the body; bslly with a median series of more or 
less enlarged spinous plates or ctenoid scales, which in most species fall off at intervals, leaving a naked strip, in some species persistent and but slightly enlarged; sides of head scaly or not; lateral line complete or nearly so; fins large, the soft dorsal smaller than the spinous or the anal; anal spines two (one of them very rarely obsolete); dorsal spines ten to fifteen; ventral fins more or less widely separated, specially in species with caducous plates. Parietal region more or less depressed, not strongly convex in cross section; supraoccipital crest usually present, but small. Pyloric cæca, two to four.

\section{Sumgenus ALVORDIUS.}

\section{(99) Black-sided Darter.}

(Hadropterus aspro.)

Body slender, fusiform, elongate; head rather long and pointed; the maxilla extends slightly past front of eye; the mandible is included; the eye large; gill membranes slightly connected; nape scaly or naked; cheeks with very small scales; large scales on opercles; caudal peduncle rather long and slender; caudal fin slightly emarginate.

D. XII. to XV., I I to I 3 ; A. II., 8 to Io. Scales, $9-65$ to $80-17$.

Colour, greenish yellow with dark tessellations and marblings above, and about seven large blotches along the side which are more or less confluent; fins barred and there is a small spot at base of caudal. Length three to four inches.

As this species is said to range all through the Great Lakes region westward to Manitoba, it probably occurs here, though I have not as yet found it.

It frequents clear streams with gravelly bottoms and is more active in its habits than most of the other Darters, not concealing itself so closely under stones.

\section{Genus COTTOGASTER.}

Body rather robust, little compressed; head moderate, biuntish; mouth moderate or small; the lower jaw included; premaxillaries protractile or occasionally joined by a narrow frenum to the frontal region; maxillary not adherent to the preorbital; teeth on vomer, gill membranes nearly separate; scales ctenoid; the middle line of the belly anteriorly naked or with caducous scales; lateral line continuous; dorsal fins large, the second usually smaller than the first and smaller than the anal; anal spines two, the first the longer; pyloric cæca three; skull short, the frontal region not very narrow, parietals little convex transversely, sutures distinct; no supraoccipital crest. 


\section{Subgenus COTTOGASTER.}

\section{(100) Copeland's Darter.}

(Cottogaster copelandi.)

Body rather slender and elongate; head rather large and long, somewhat narrowed. Mouth small, horizontal, subinferior; cheeks naked; opercles and neck each with a few scales; throat naked; ventral plates well developed; scales moderate; strongly ctenoid.

D. X. to XII., 10 to 12 ; A. II., 8 or 9 . Scales, $6-44$ to $56-8$.

Colour, brownish olive; a series of rather small, horizontally oblong black blotches along the lateral line, forming an interrupted lateral band; back tassellated; blackish streaks forward and downward from eye; ventral fins dusky in the male; vertical fins with dusky specks; a small inklike speck at base of caudal, persistent in most specimens; a black spot on anterior rays of spinous dorsal.

Length, about three inches. The range of a variety of this species, C. c. putnami, is from Lake Champlain to Lake Huron. It will therefore probably be found in our waters, though I have not yet obtained it.

\section{Genus BOLeOSOMA (Tessillated Darters.)}

Body moderately elongate, fusiform, but slightly translucent; head small, narrowed forward, the profile convex; mouth small, horizontal, the lower jaw included; premaxillary protractile; maxillaries not adnate to preorbital; vomerine teeth present; scales large; lateral line continuous or interrupted behind; belly with ordinary scales; gill membranes broadly or narrowly connected; dorsal spines usually nine, very slender and flexible, soft dorsal much larger than anal; anal normally with a single, short slender spine, the first soft ray simple, but articulate; ventrals well separated; pyloric cæca, three to six; frontal region of skull very short and narrow; parietal region flattish above; no supraoccipital crest. Size small, very active little fishes.

\section{(IOI) Johnny Darter.}

(Boleosoma nigrum.)

Body slender, fusiform; head conical; snout somewhat decurved; mouth small, subinferior, lower jaw included within the upper. Gill covers scaly, cheeks naked except in occasional individuals; nape usually scaled.

D. VIII. to X., io to $14 ;$ A. I., 7 to 9 . Scales, 5-44 to 55-9.

Colour, olivaceous; the back with brown tessellations; sides with many W-shaped blotches. The head is speckled above, in males usually black. In the breeding season the whole anterior part of the male is often black. A dark line forward from the eye and sometimes another downward. Length, about two and a-half inches. This species is common 
through the Great Lakes region, more particularly so in the west and north; in the southern and eastern parts of the Province it is represented by the following sub-species:

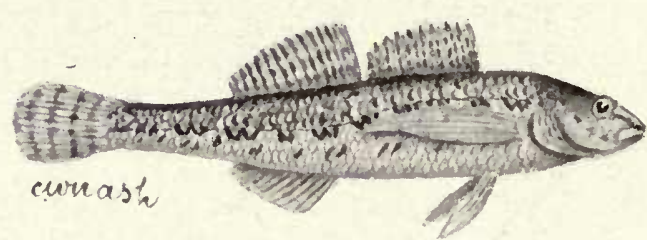

Tessellated Darter. (Boleosoma nigrım olmstedi.)

\section{(102) Tessellated Darter.}

(Boleosoma nigrum olmstedi.)

Very similar to the last, but the cheeks and opercles scaly and nape and breast naked. Lateral line complete.

D. IX., I4; A. I., 9. About 50 scales on lateral line.

Colour, olivaceous; fins with many narrow bars; back tessellated; sides with blotches and zigzag markings. Head in spring, males black. A dark streak forward from the eye and another downward.

This is the most abundant and generally distributed Darter we have. It is found in most streams and quiet sandy bays of the southern and eastern parts of the Province, where it lies secreted under stones on the bottom, or buries itself in the sand, leaving only its eyes visible. When alarmed it darts with great rapidity to the nearest shelter and trusts to concealment for protection. It grows to a length of about three inches and is interesting by reason of its peculiar habits.

\section{Genus AMMOCRYPTA. (Sand Darters.)}

Body slender and elongate, subcylindrical; pellucid in life. Head slender. Mouth rather wide, horizontal, the lower jaw included; premaxillaries very protractile; teeth on the vomer. Scales thin, ctenoid, little imbricated, present along the region of the lateral line, and on the tail, sometimes wanting on the back or belly; lateral line complete, each tube occupying nearly the whole length of its scale. Head scaly or naked; no ventral plates, the belly naked. Gill membranes considerably united, forming an angle at their junction. Dorsal fins moderate, about equal to the anal fin and to each other; dorsal with about ten spines; anal spine weak; ventrals well separated, behind pectorals, their spines feeble; pectorals pointed, symmetrical, of twelve to fifteen rays. Pyloric cæca, four. Frontal region of skull narrow, the parietal region unusually depressed; the bones of skeleton all slender and thin. Sutures of skull very distinct; supraoccipital crest obsolete. Foramen of hypercoracoid very large. 


\section{( 103 ) Sand Darter.}

(Ammocrypta pellucida.)

Scales of body not very rough, only those along lateral line and on tail well imbricated; nape thinly scaled, becoming usually wholly naked on median line; belly naked; maxillary barely reaching the large eye; pectorals short.

D. IX., 9 to I I A. I., 8 to ro. Scales on lateral line, 67 to 78 .

Colour, translucent; scales with fine black dots; a series of small, squarish olive or bluish blotches along the back and another along each side; lateral spots connected by a gilt band. Length, three inches.

As this little fish has a range from Lake Erie to Minnesota, it will probably be found in our Province, though as yet I have not taken it here. It frequents clear sandy streams and avoids observation by burying itself in the sand, leaving only its eyes and snout visible.

\section{Genus ETHEOSTOMA.}

Body robust, or rather elongate, compressed; mouth terminal, or subinferior, varying in size; the lower jaw included or projecting; premaxillaries not protractile; maxillary movable; teeth rather strong, usually present on vomer and palatines; gill membranes separate or more or less broadly connected; scales moderate or small, ctenoid, top of head without scales; scales of the middle line of the belly persistent and similar to the others; lateral line well developed, nearly straight, often wanting posteriorly; fins large, with strong spines, first dorsal usually longer and larger than the second, with seven to fifteen spines; anal with two strong spines, the anterior usually the larger, the second rarely obsolete, anal fin always smaller than the soft dorsal; ventral fins more or less close together; skull narow, the parietal region very strongly convex in cross-section, supraoccipital crest very small or wanting; lower pharyngeals very narrow; pyloric cæca three or four; bones rather firm. Many of the species are excessively variable.

\section{Subgenus NIVICOLA.}

\section{(I 04$)$ Northern Darter.}

(Etheostoma boreale.)

Body moderately elongate, somewhat compressed, the caudal peduncle rather long and stout. Head rather heavy, the snout bluntish, rather strongly decurved. Anterior profile gently and somewhat evenly arched. Snout short, about half as long as eye. Mouth nearly horizontal, the lower jaw included, the maxillary extending to about opposite front of pupil. Teeth small. Preopercle entire; opercular spine strong. Premaxillary not protractile. Gill membranes very slightly connected. A small black humeral scale; cheeks, opercles and nuchal region scaly; breast naked; scales of moderate size; lateral line very short, not reaching last spine of 
dorsal, running rather high and slightly arched. Scales of belly like those of the sides. Dorsal fins well separated, unusually short and small; soft dorsal a little higher than spinous dorsal, also unusually small for this genus; caudal long, truncate or slightly lunate; anal low and short, its spines high, the first highest; pectorals reaching past tips of ventrals.

D. IX., Io; A. II., 6 or 7 . Scales, 4-52-10.

Colour, soft dorsal caudal and pectoral fins with dark bars and a brownish red tinge, other fins white; a brownish red tinge on sides, most conspicuous between the darker markings; ten or eleven black bars across the back, those on the sides are more or less broken up and not so evident. Length, two and a-half inches.

This Darter was first known only from a small stream near Montreal. Since then it has been found in Gull Lake, Muskoka. In all probability it inhabits many of the clear streams of central Ontario.

\section{FAMII.Y SERRANIDA.}

Body oblong, more or less compressed, covered with adherent scales of moderate or small size, which are usually but not always ctenoid; dorsal and ventral outlines usually not perfectly corresponding. Mouth moderate or large, not very oblique, the premaxillary protractile and the broad maxillary usually not slipping for its whole length into a sheath formed by the preorbital, which is usually narrow. Supplemental maxillary present or absent. Teeth all conical or pointed, in bands, present on jaws, vomer and palatines. Gill rakers long or short, usually stiff, armed with teeth. Gills four, a long slit behind the fourth. Pseudobranchia present, large. Lower pharyngeals rather narrow, with pointed teeth. Gill membranes separate, free from the isthmus. Branchiostegals normally seven (occasionally six). Cheeks and opercles always scaly; preopercle with its margin more or less serrate, rarely entire; the opercles usually ending in one or two flat spine-like points. Nostrils double. Lateral line single, not extending to the caudal fin. Skull without cranial spines and usually without well developed cavernous structure. No suborbital stay. Posttemporal normal, second suborbital with an internal lamina supporting the globe of the eye ; enteroptygoid present ; all or most of the ribs inserted on the transverse processes when these are developed; anterior vertebræ without transverse processes. Dorsal spines usually stiff; anal fin rather short, its soft rays seven to twelve; its spines if present always three in our species. Ventrals thoracic without distinct axillary scale. Pectorals well developed, with narrow base, the rays branched. Caudal peduncle stout. Air bladder present, usually small and adherent to the wall of the abdomen. Stomach cacal, with few or many pyloric appendages; intestines short, as is usual in carnivorous fishes. 



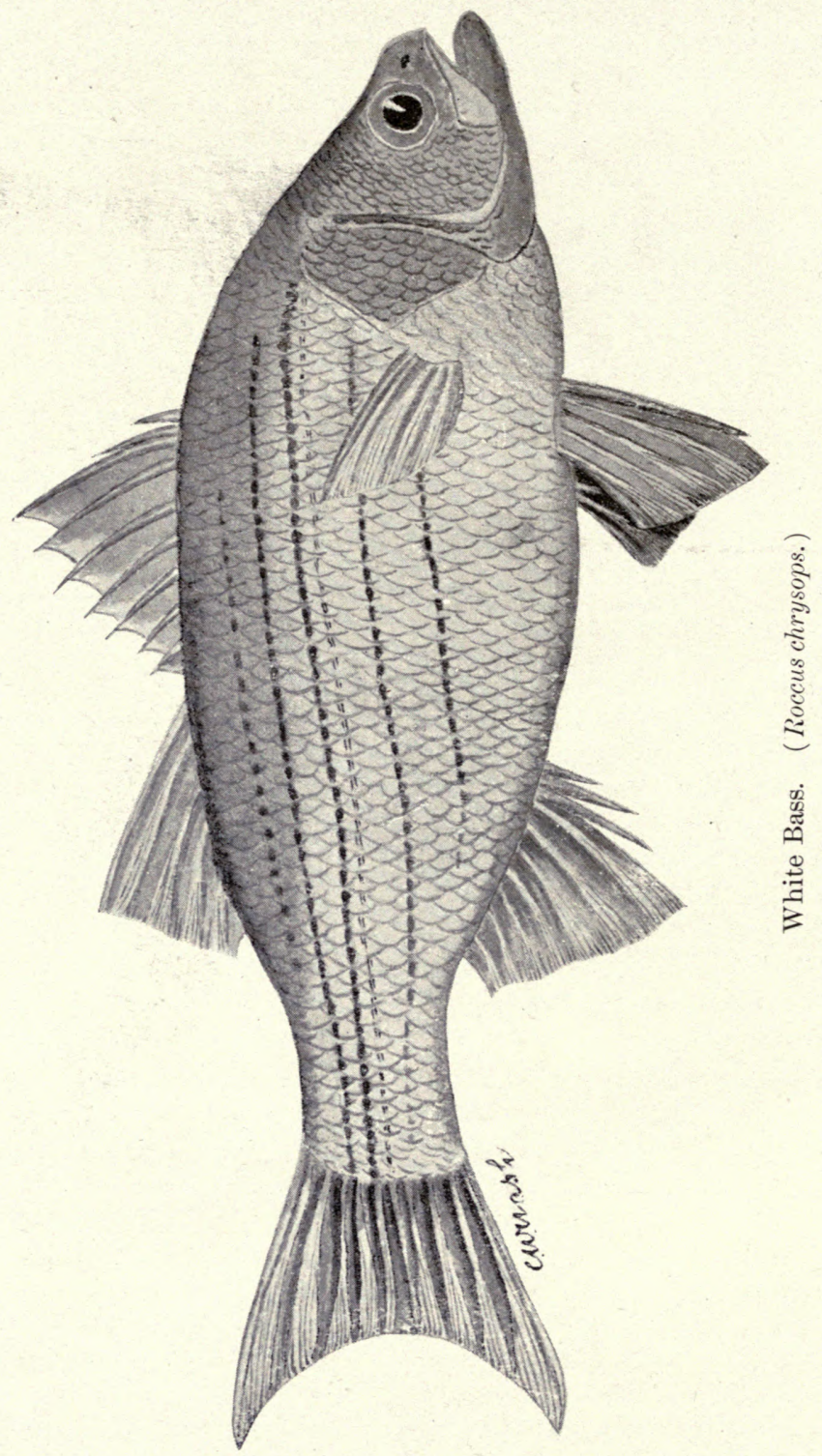




\section{Genus ROCCUS. (Striped B.iss.)}

Base of tongue with one or two patches of teeth; anal spines graduated; dorsal fins entirely separate; anal rays III., I I or I 2 ; supraoccipital crest scarcely widened above; lower jaw projecting.

\section{SubGenus LEPIBEMA.}

(105) White Bass.

(Roccus chrysops.)

Body oblong, elevated and compressed; head subconical, depressed over eye; mouth moderate, the maxillary reaching to below middle of eye; villiform teeth in bands on jaws, palatines vomer and tongue; the dorsal outline much curved.

D. IX., I., I4; A. III., 1 I to I2. Scales, 8-60-I3.

Colour, silvery, tinged with golden below; sides with narrow dusky lines, about five above the lateral line, one along it and a variable member below, these sometimes more or less interrupted or transposed. Length, twelve to fifteen inches; weight, about a pound and a half.

The White Bass is found in all the Great Lakes of Ontario; it rarely ascends streams, but occurs sometimes abundantly at the mouth of the larger rivers. It is gregarious, usually swimming in shoals containing a large number of individuals. As a game fish it ranks high, for it takes minnow bait readily, and during the summer months rises to a fly well. It is an excellent table fish when fresh caught.

It spawns in May or June.

\section{Suborder RHEGNOPTERI.}

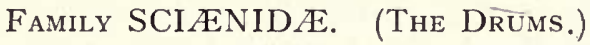

Body compressed, more or less elongate, covered with thin more or less ctenoid scales. Lateral line continuous, extending on caudal fin; head usually large, scaly; bones of head cavernous, the muciferous system highly developed, the surface of the skull very uneven; chin with pores; nouth and teeth various; maxillary without supplemental bone, slipping bi:neath preorbital; premaxillaries protractile; nostrils double; pseudobranchiæ usually present and usually large; branchiostegals seven; gill memhranes separate, free from the isthmus; lower pharyngeals separate or urited, often enlarged, the teeth conic or molar; preopercle serrate or not, opercle usually ending in two flat points; dorsal deeply notched or divided into two fins, the soft portion being the longer, the spines depressible into a groore; anal with never more than two spines; caudal usually not forked; ear-bones or otoliths very large; air bladder usually large and complicated, its structure enabling the fish to make grunting or drumming sounds. 


\section{Genus APLODinotus. (Fresh-ivater Drum.)}

Body oblong, the snout blunt, the back elevated and compressed; mouth rather small, low, horizontal, the lower jaw included; teeth in villiform bands, the outer above scarcely enlarged; no barbels; pseudobranchiæ rather small; gill rakers short and blunt; lower pharyngeals very large, fully united, with coarse blunt paved teeth; preopercle slightly serrate; dorsal spines strong and high, with a close fitting scaly sheath at base, the two dorsals somewhat connected; second anal spine very strong; caudal double truncate; air bladder very large, simple, with no appendages; pyloric cæca, seven; vertebræ, $10+14=24$.

\section{(106) Sheepshead. Fresh-water Drum.}

(Aplodinotus grunniens.)

Body moderately elongate, somewhat compressed; head rather short; snout obtuse; maxilla reaches to below the middle of the eye; lower jaw shorter than the upper.

D. IX. I., 30 to 3 I ; A. II., 7 . The scales are very irregularly placed, about fifty-five on the lateral line.

Colour, greyish, darker on the back; lower parts silvery. Young specimens have dark spots along the rows of scales, forming oblique lines.

A common fish distributed throughout the entire Great Lakes region and particularly abundant in Lake Erie. It reaches a large size, specimens of over fifty pounds' weight having been taken from southern waters. With us, however, about eight or ten pounds would be the maximum.

It is a bottom fish, feeding chiefly upon crustaceans and molluscs. It occasionally takes a minnow bait, but I have not found it a ready biter. When hooked it fights hard and affords good sport to the angler, but as a food fish it is worthless, its flesh being tough and coarse, with an unpleasant odour.

The name Jewel-head sometimes given to this fish refers to the otoliths, or ear-bones, frequently called "lucky stones," which are found in its skull.

\section{Order PLECTOGNATHI. (The Plectognathous Fishes.)}

One of the most important offshoots of the Acanthopteri is the group or order Plectognathi. The extremes of this group show a remarkable divergence from the usual type of spiny-rayed fishes.

The Plectognathi are thus defined by Dr. Gill: Scapula suspended to the cranium by a post-temporal which is short, undivided and anchylosed to the epiotic. Premaxillaries usually coössified with the maxillaries behind and the dentary bones with the articular; interopercle a slender rod; lower pharyngeal bones distinct; upper pharyngeals laminar, usually vertical and transverse; skin usually with rough shields or scales or bony plates; skeleton imperfectly ossified, the number of vertebræ usually small, typically less than 24 (usually 14 to 20 ), rarely considerably increased. Gill 



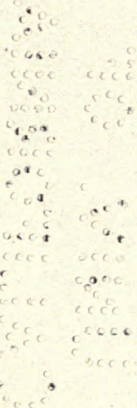


openings restricted to the sides; ventral fins reduced or wantirg, the pelvic; bones usually elongate. Spinous dorsal small or wantling; "air bladde" without duct.

Fishes mostly inactive and depending on their tough skin or bony or spinous armature for their protection.

\section{Suborder LORICATI.}

\section{Family COTTIDAE. (The Sculpins.)}

Body more or less elongate, the head usually large and depressed; eyes high; bony stay conspicuous, but not covering the cheek; preopercle armed; teeth in villiform bands; maxillary simple; gills three and a half or four; gill membranes connected, often joined to isthmus. Body naked, or irregularly scaled, or warty, never evenly scaled; lateral line present. Dorsals usually separate, the spines slender; anal without spines; pectorals large, with broad procurrent base, the lower rays simple; ventrals thoracic, sometimes wanting, never united. Pseudobranchiæ present. Vertebræ numerous, thirty-five to fifty.

\section{Group COTTIN A.}

\section{Genus COTtus. (Fresh-water Sculpins.)}

Body fusiform. Head feebly armed; skin smooth or more or less velvety, its prickles, if present, not bony or scalelike; villiform teeth on jaws and vomer and sometimes on palatines. Gill openings separated by a wide isthmus over which the membranes do not form a fold; no slit behind the fourth gill. Branchiostegals six. Dorsals nearly or quite separate, the first of six to nine slender spines; ventrals moderate, each with a short, concealed spine and four soft rays. Lateral line present, usually more or less chain-like, sometimes incomplete. Preopercle with a simple spine at its angle, which is usually curved upward, its base more or less covered by skin, very rarely obsolete, usually two or three spines turned downward below this; subopercle usually with a concave spine turned downward. Vertebræ, $10+23=33$. Pyloric cæca, about four.

\section{Subgenus PEGEDICTUS.}

(107) Miller's Thumb. Blob.

(Cottus ictalops.)

Body rather robust, gradually tapering to the tail ; head very broad; preopercle with a short, sharp, straightish spine, turned upward and backward, with two smaller spines below it; skin usually smooth, sometimes with minute prickles behind axil of pectoral; spinous dorsal begins slightly behind end of head, separated from second dorsal by a deep notch ; second dorsal about two and one-third times longer than first and one-third longer than anal base. Pectoral, ventral and caudal fins well developed. 
D. VI. to VIII., I6; A., I2 to I3.

Colour, olivaceous, much speckled; sides usually with several distinct and rather broad cross bands; fins barred and mottled. Length, five or six inches. Very variable in size, colour, and length of fins.

This fish ranges through the entire Great Lake Region and is abundant in some of the Lake Superior trout streams, where it is said to be very destructive to the eggs and young of Brook Trout.

\section{Genus URANideA. (Miller's Thumbs.)}

This genus is very close to Cottus, from which it differs in the reduction of its ventrals to a concealed spine and three soft rays, a step further in the degeneration characteristic of fresh-water types. The skin is smooth or very nearly so, the preopercular spines small, and there is usually no trace of teeth on the palatines.

\section{(rog) Franklin's Sculpin.}

(Uranidea franklini.)

Body rather short and stout; snout not very obtuse; maxillary reaching about to pupil; eye four in head; preopercular spine hook-like, very acute; paired fins rather short, the pectorals not reaching vent ; first dorsal nearly as high as second; dorsals contiguous; anal inserted under fourth ray of second dorsal; caudal six in length; lateral line incomplete; vent nearer base of caudal than tip of snout.

D. VIII., I7 ; A., I2; V. I., 3 .

Length, three inches.

Lake Superior.

\section{(108) Lake Miller's Thumb.}

(Uranidea formosa.)

Body slender and graceful; head small, depressed above; eyes moderate; preopercular spine short, stout, acute, curved upwards; a small spine below it; subopercular spine well developed. Dorsals well separated; anal beginning under third ray of soft dorsal; pectorals not reaching to posterior margin of spinous dorsal; ventrals not nearly to vent.

D. VIII., I6; A. II. Length, three and one-fourth inches.

A single mutilated specimen has been recorded, this having been found by Prof. S. F. Baird in the stomach of a Burbot (Lota maculosa) taken from Lake Ontario.

\section{Genus TRIGLOPSIS.}

Body and head slender; skin naked; lateral line chainlike; teeth on vomer, none on the palatines; eye large, the interorbital area concave; 
bones of lower part of head extensively cavernous; a small but distinct slit behind last gill; gill membranes almost free from the isthmus, forming a broad fold across it; preopercular spines straight, simple, four in number, the lower turned downward; fins large.

\section{( I Io) Lake Sculpin.}

(Triglopsis thompsoni.)

Body elongate, very slender. Head long, depressed above. Snout long and pointed; eye quite large; jaws subequal; mouth large; the maxillary extending rather beyond middle of eye; preopercle with four sharp spines; cavernous structure of skull highly developed; upper surface of head smooth; gill membranes not broadly united; nearly free from isthmus. Dorsal fins well separated; spinous dorsal short and low; second dorsal very large; anal high; pectoral long, reaching past front of anal; ventrals well developed; lateral line chain-like, conspicuous; skin perfectly smooth.

D. VII., I8; A., I5. banded.

Colour, pale olivaceous with darker blotches; upper fins faintly

Little is known of this species. Specimens have been taken occasionally from deep water in Lake Ontario, but there are no other records for this Province.

\section{Suborder ANACANTHINI.}

\section{Family GADIDA. (Codfishes.)}

Body elongate, ending in an isocercal tail; scales small, cycloid. Mouth large, the teeth various. No pseudobranchiæ. Vertical fins separate. Dorsal and anal long; no fin spines. Gill openings very wide, the membranes free from the isthmus. Gills four; air bladder present. Pyloric cæca numerous. Vertebræ, about fifty.

Carnivorous fishes chiefly of the northern seas, many of them of great economic value. One species in fresh waters.

\section{Genus LOTA. (Lings.)}

Body long and low, compressed behind; head small, depressed, rather broad; anterior nostrils each with a small barbel; chin with a long barbel; snout and lower parts of head naked; mouth moderate, the lower jaw included; each jaw with broad bands of equal villiform teeth; vomer with a broad crescent-shaped band of similar teeth; no teeth on palatines; gill openings wide, the membrane somewhat connected, free from the isthmus ; scales very small, embedded; vertical fins scaly; dorsal fins two, the first short, the second long, similar to the anal; caudal rounded, its outer rays procurrent; ventrals of several rays. 
( I I ) Burbot. Ling.

(Lota maculosa.)

Body elongate, somewhat eel-shaped, slightly compressed posteriorly. Eye small. The upper jaw reaches slightly beyond the hind margin of the eye; the lower jaw included in the upper, and has a stout barbel which is nearly one-fifth as long as the head. The ventral is.longer than the pectoral, but does not reach half way to vent; the dorsal fins are separated by a narrow interspace, second dorsal higher than first; caudal rounded; the scales are deeply embedded in the skin, not imbricated.

D., I3, 68 to $76 ;$ A., 67 .

Colour, dark olivaceous, reticulated with blackish, the lower parts yellowish or dusky; the dorsal, anal, and caudal fins with a narrow, dark edge.

The average length of this species in our waters is about two feet. It is found in all the larger lakes and rivers of the Province, usually in deep water, except during the spawning season in the spring, when it runs into streams or on to rocky shallows.

In this Province it is considered worthless as a food or game fish, but in the Yukon and some parts of the far north its flesh is eaten and its liver is considered a delicacy. 



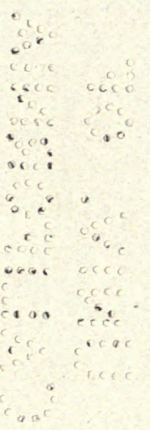




\section{APPENDIX.}

\section{BLUE DARTER ; RAINBOW DARTER (Etheostoma coruleum).}

Head $3 \frac{3}{4}$, depth $4 \frac{1}{4}$, eye 4 to $4 \frac{1}{2}$ in head, little shorter than snout, D. IX to XII-I2 to I4. A. II., 7 or 8 ; scales $5-37$ to $50-10$ usually 5$45=10$ pores 18 to 35 . Body robust, rather deep and compressed, the back somewhat elevated. Head large, compressed. Mouth moderate, terminal, oblique, the lower jaw somewhat included the maxillary, reaching front of orbit; opercular spine moderate; gill membranes not connected. Palatine teeth in one row. Cheeks naked or nearly so, opercles scaled; neck and breast usually naked. Fins all large, dorsal fins usually slightly connected. Anal spines subequal, or the first a little the longer: caudal rounded; pectoral nearly or quite as long as head.

Males olivaceous tessellated above, the spots running together into blotches; back without black lengthwise stripes; sides with about I 2 indigo blue bars running obliquely downward and backward, most distinct behind, separated by bright orange interspades; caudal fin deep orange, edged with bright blue, anal fin orange, with deep blue in front and behind; soft dorsal, chiefly orange, blue at base and tip; spinous dorsal, crimson at base, then orange with blue edgings; ventrals deep indigo; cheeks blue; throat and breast orange; females much duller, with little blue or red, the vertical fins barred or checked; young variously marked, no dark humeral spot. Length $2 \frac{1}{2}$ inches.

Gayest of all the Darters, and indeed the gaudiest of all fresh water fishes.

It makes its home in the ripples and shallows of the rivers and in the shady retreats of brooks.

It is a chubby little fish as compared with the other Darters. In its movements it is awkward and ungraceful, though swift and savage as a Pike. One of the mildest of its tricks which we have noticed is this. It would gently put its head over a stone and catch a water boatman by one of its swimming legs, release it, catch it again and again release it, until at last the boatman evidently much annoyed swam away out of its reach. It will follow to the surface of the water a piece of meat suspended by a string. It is more alert in discovering this than a hungry Sunfish or Rock Bass, and it can be led around like a pet lamb by a thread to which is fastened a section of a worm. (Jordan and Evermann).

While this work was in the printers' hands, I took several specimens of this beautiful fish in a swift, rocky stream, flowing through the eastern side of the County of York.

\section{LONG=NOSED DACE (Rhinicthys cataractæ).}

At the same place where I found the Blue Darter, this species was abundant; it is probable therefore that it is more generally distributed through the Province than has been heretofore supposed. 


\section{GLOSSARY OF TECHNICAL TERMS.}

A.

Abdomen. Belly.

Aberrant. Deviating from ordinary character.

Abortive. Remaining or becoming imperfect.

Actinosts. A series of bones at the base of the pectoral rays.

Acuminate. Tapering gradually to a point.

Acute. Sharp-pointed.

Adipose fin. A peculiar fleshy fin-like projection behind the dorsal fin, on the backs of salmons, catfishes, etc.

Adult. A mature animal.

A githognathus. Having the peculiar palate of passerine birds.

Air-bladder. A sac filled with air, lying beneath the backbone of fishes, corresponding to the lungs of the higher vertebrates.

Albinism. State of whiteness, complete or partial, arising from deficiency or entire lack of pigment in the skin and its appendages.

Alisphenoid. A small bone on the anterior wall of the brain-case.

Allantois. An organ of the embryo.

Altrices. Birds hatched in an immature condition, reared in the nest and fed by the parents.

Altricial. Having the nature of altrices.

Alula. Literally, little wing. The feathers attached to the so-called "thumb" of a bird.

Alveolar surface. A portion of the jaw of a Turtle, where the teeth sockets are developed in other reptiles.

Amnion. An organ of the embryo.

Amphicœlian. Double-concave, said of vertebræ.

Anadromous. Running up-said of marine fishes which run up rivers to spawn.

Anal. Pertaining to the anus or vent.

Anal fin. The fin on the median line behind the vent on fishes.

Anal plate. The plate immediately in front of the vent on serpents, often divided in two by a median suture.

Anchylosed. Grown firmly together.

Angular. A small bone on the posterior end of the mandible.

Anteorbital plate. The plate (one or two) in front of the eye in serpents, with its longest diameter vertical; also called preocular.

Antrorse. Turned forward.

Anus. The external opening of the intestine; the vent.

Arboreal. Living in trees.

Arterial bulb. The muscular swelling at the base of the great artery, in fishes. 
Articular. The bone of the mandible, supporting the dentary.

Articulate. Jointed.

Artiodactylous. Even-toed (2 or 4).

Atlas. The first vertebra.

Atrophy. Non-development.

Attenuate. Long and slender, as if drawn out.

Auditory capsule. The ventrolateral swelling of the skull.

Auricle. The large lobe of the external ear; also one of the chambers of the heart.

Axillars. Elongated feathers on the sides of the body under the wings.

B.

Band or bar. Any colour mark transverse to the long axis of the body. Barbel. An elongated fleshy projection usually about the head in fishes. Basal. Pertaining to the base; at or near the base.

Basibranchials. A lower median series of bones of the branchial arches.

Basioccipital. A median posterior ventral bone of the skull to which the atlas is attached.

Basipterygoid. Bones developed in the palatine arch in some birds.

Basis cranii. Formed by shelves of bone developed from the inner sides of the prootics, which meet and form a root to the myodome and a floor to the brain cavity.

Beak. The bill of birds or (in other animals) any beak-like structure.

Bend of wing. Angle at the carpus when the wing is folded.

Bicolour. Two-coloured.

Bicuspid. Having two points.

Booted. Said of the tarsus in birds, when its scales coalesce and form a continuous envelope, as in the Robin.

Brachial ossicles. Synonymous with actinosts.

Branchiæ. Gills; respiratory organs of fishes.

Branchial. Pertaining to the gills.

Branchihyals. Small bones at base of gill arches.

Branchiostegals. The bony rays supporting the branchiostegal membranes under the head of a fish, below the opercular bones and behind the lower jaw.

Bristle. A stiff hair, or hair-like feather.

Buccal. Pertaining to the mouth.

C.

Caducous. Falling off early.

Cacal. Of the form of a blind sac.

Cæcum. An appendage of the form of a blind sac connected with the alimentary canal. 
Calcareous. Chalky.

Canines. The teeth behind the incisors-the "eye teeth" in fishes; any conical teeth in the front part of the jaws, longer than the others.

Canthus. Corner of the eye where the lids meet.

Carapace. The upper shell of a Turtle, usually composed of bony plates covered by horny scales.

Cardiform. (Teeth.) Teeth coarse and sharp, like wool cards.

Carinate. Keeled, having a ridge along the middle line.

Carotid. The great artery running to the head.

Carpal angle. Prominence at the wrist-joint when the wing is closed. From this point to the end of the longest quill constitutes the "length of wing."

Carpus. The wrist.

Catadromous. Running down; said of fresh water fish which run down to the sea to spawn.

Caudal. Pertaining to the tail.

Caudal fin. The fin on the tail of fishes and whales.

Caudal peduncle. The region between the anal and caudal fins in fishes.

Cavernous. Containing cavities either empty or filled with a mucous secretion.

Centrum. The body of a vertebra.

Cephalic fins. Fins on the head of certain rays; a detached portion of the pectoral.

Ceratobranchials. Bones of the branchial arches just below their angle.

Ceratohyal. One of the hyoid bones.

Cervical. Pertaining to the neck.

Chiasma. Crossing of the fibres of the optic nerve.

Chin. Space between the forks of the lower jaw.

Ciliated. Fringed with eyelash-like projections.

Cirri. Fringes.

Claspers. Organs attached to the ventral fins in the male of Sharks, Rays, etc.

Clavicle. The collar-bone, or lower anterior part of shoulder girdle not entering into socket of arm.

Cloaca. A common opening of genital, urinary and alimentary canals.

Commissure. The line upon which the mandibles of a bird are closed.

Compressed. Flattened laterally.

Condyle. Articulating surface of a bone.

Conirostral. Said of a bill like that of a Sparrow; conical in form and with the commissure angulated.

Coracoid. The principal bone of the shoulder girdle in fishes; otherwise a bone or cartilage on the ventral side, helping to form the armsocket.

Costal folds. Folds of the skin (of a Salamander) showing the position of the ribs (costæ). 
Coverts. Small feathers hiding the bases of the quills.

Cranial. Pertaining to the cranium or skull.

Crest. In birds any lengthened feathers about the head; elsewhere any elevated or crest-like projection.

Crissum. The under tail coverts in birds.

Ctenoid. Rough-edged; said of scales when the posterior margin is minutely spinous or pectinated.

Culmen. The middle line or ridge of the upper mandible in birds.

Cuneate. Wedge-shaped; said of a bird's tail when the middle feathers are longest and the rest regularly shorter.

Cycloid. Smooth-edged; said of scales not ctenoid, but concentrically striate.

\section{D.}

Deciduous. Temporary; falling off.

Decomposed. Separate; standing apart.

Decurved. Curved downward.

Dentary. The principal or anterior bone of the lower jaw, usually bearing the teeth.

Dentate. With tooth-like notches.

Denticle. A little tooth.

Dentirostral. Having the bill notched near its tip.

Depressed. Flattened vertically.

Depth. Vertical diameter (usually of the body of fishes).

Dermal. Pertaining to the skin.

Desmognathous. United palate, as in the lower water birds (Loons, Gulls, etc.).

Diagnostic. Distinctively characteristic.

Diaphanous. Translucent.

Diaphragm. Muscular septum between thorax and abdomen.

Diapophysis. Transverse process of a vertebra.

Digitigrade. Walking on the toes like a dog.

Distal. Remote from point of attachment.

Dorsal. Pertaining to the back.

Dorsal fin. The fin on the back of fishes.

E.

Emarginate. Slightly forked, or notched at the tip ; abruptly narrowed or notched toward the tip (said of quills).

Endoskeleton. The skeleton proper; the inner bony framework of the body.

Enteron. The alimentary canal. 
Epibranchials. The bones directly above the angle of the branchial arches. Epiliyal. One of the hyoid bones.

Epipleurals. Rays of bone attached to the ribs and anterior vertebræ, usually touching the skin in the vicinity of the lateral line.

Erectile. Susceptible of being raised or erected.

Erythrism. A peculiar reddish state of plumage.

Ethmoid. A median anterior bone of the skull.

Eustachian tubes. Tubes connecting the inner ear with the pharynx.

Even (tail). Having all the feathers of equal length.

Exoccipitals. Two bones of the skull, one on each side of the foramen magnum.

Exoskeleton. Hard parts (scales, scutes, feathers, hairs) on the surface of the body.

Exserted. Projecting beyond the general level.

Extra-limital. Beyond the limits.

F.

Facial. Pertaining to the face.

Falcate. Sickle-shaped; long, narrow and curved.

Falciform. Curved like a scythe:

Fauna. The animals inhabiting any region taken collectively.

Femoral. Pertaining to the thigh, or proximal bone of the hinder leg.

Ferruginous. Rusty red.

Fibula. The small outer leg bone.

Filament. Any slender or thread-like structure.

Filiform. Thread-form.

Fissirostral. Having the bill very deeply cleft, beyond the base of the horny part, as in the Swallows.

Fontanel. An unossified space on top of head covered with membrane.

Foramen. A hole or opening.

Foramen magnum. The aperture in the posterior part of the skull for the passage of the spinal cord.

Forehead. Frontal curve of head.

Forficate. Deeply forked; scissors-like.

Fossœ (nasal). Grooves in which the nostrils open.

Fossorial. Adapted for digging.

Frontal bone. Anterior bone on top of head, usually paired.

Fulcra. Rudimentary spine-like projections extending on the antericr rays of the fins of ganoid fishes.

Fuliginous. Sooty-brown.

Fulvous. Of a brownish yellow colour.

Furcate. Forked.

Fuscous. Of a dark grayish-brown colour.

Fusiform. Spindle-shaped; tapering towards both ends, but rather more abruptly forward. 
G.

Ganglion. A nerve centre.

Ganoid. Scales or plates of bone covered by enamel.

Gape. Opening of the mouth.

Gastrosteges. Band-like plates along the belly of a serpent; ventral plates.

Gibbous. Swollen; protuberant.

Gills. Organs for breathing the air contained in water.

Gill-arches. The bony arches to which the gills are attached.

Gill-openings. Openings leading to or from the branchiæ.

Gillrakers. A series of bony appendages variously formed along the inner edge of the anterior gill arch.

Glabrous. Smooth.

Glossohyal. The tongue bone.

Gonys. The middle line of the lower mandible.

Gorget. Throat patch of peculiar feathers.

Graduated (spines). Progressively longer backward; the third being as much longer than serrnd as second is longer than first.

Graduated (tail). One in which the outer feathers are regularly shorter from the middle.

Granulate. Rough with small prominences.

Gular. Pertaining to the upper fore-neck.

Guttate. Having drop-shaped spots.

H.

Hæmal arch. An arch under a hæmal spine for the passage of a bloodvessel.

Hamal canal. The series of hæmal arches as a whole.

Hæmal spine. The lowermost spine of a caudal vertebra, in fishes.

Hamopophyses. Appendages on the lower side of abdominal vertebræ in fishes.

Hallux. The great toe-in birds the hind toe.

Height. Vertical diameter.

Heterocercal. Said of the tail of a fish when unequal - the backbone evidently running into the upper lobe.

Hirsute. With shaggy hairs.

Homocercal. Said of the tail of a fish when not evidently unequal; the backbone apparently stopping at the middle of the base of the caudal fin.

Humerus. Bone of the upper arm.

Hyoid. Pertaining to the tongue.

Hyoid apparatus. Formed by a series of bones extending along the inner side of the mandible and supporting the tongue. 
Hyomandibular. A bone by which the posterior end of the suspensorium is articulated with the skull ; the supporting elentent of the suspensorium, the mandible, the hyoid apparatus, and the opercular apparatus.

Hypercoracoid. The upper of the two bones attached to the clavicle indirectly bearing the pectoral fin.

Hypleural. The modified last vertebra supporting the caudal fin.

Hypobranchials. Bones of the branchial arches below the ceratobranchials.

Hypocoracoid. The lower of the two bones attached to the two clavicles behind.

Hypognathous. Having the lower mandible longer than the upper, as in the Black Skimmer.

Hypophyals. Small bones, usually four, by which the respective sides of the hyoid apparatus are joined.

Imbricate. Overlapping, like shingles on a roof.

Imperforate. Not pierced through.

Inarticulate. Not jointed.

Incisors. The front, or cutting teeth.

Infraoral. Below the mouth.

Interfemoral membrane. The membrane connecting the posterior limbs of a bat.

Interhamal spines. Elements supporting the anal fin.

Interhamals. Bones to which anal rays are attached in fishes.

Interhyal. Upper hyoid bone attached to hyomandibular.

Intermaxillaries. The premaxillaries; the bones forming the middle of the front part of the upper jaw in fishes.

Intermusculars. Synonym of epipleurals.

Internasals. Plates on the forehead of the snake on the line connecting the two nostrils.

Interneurals. Bones to which the dorsal rays are attached in fishes.

Interopercle. Membrane bone between the preopercle and the branchiostegals.

Interorbital. Space between the eyes.

Interscapular. Between the shoulders.

Interspinals. Bones to which fin-rays are attached (in fishes) inserted between neural spines above and hæmal spines below.

rsocercal (tail). Last vertebræ progressively smaller and ending in median line of caudal fin as in the Cod-fish.

Isthmus. The narrow unperforated floor of the mouth, between the gill openings in fishes. 
J.

Jugular. Pertaining to the lower throat; said of the ventral fins when placed in advance of the attachment of the pectorals.

Jugulum. The lower throat.

K.

Keeled. Having a ridge along the middle line.

L.

Labials. Plates forming the lip of a serpent.

Lacustrine. Living in lakes.

Lamellæ. Plate-like processes, such as are seen inside a duck's bill.

Lamellate. Said of a bill provided with lamellæ, as in a duck.

Lanceolate. Shaped like the head of a lance.

Larva. An immature form, which must undergo change of appearance before becoming adult.

Larynx. A hollow cartilaginous organ; a modification of the windpipe. Lateral. To or towards the side.

Lateral line. A series of muciferous tubes forming a raised line along the sides of a fish.

Lateral processes. Synonym of parapophyses.

Laterally. Sidewise.

Lobate. Furnished with membranous flaps; said of the toes of birds.

Lobe. Membranous flap.

Longitudinal. Running lengthwise.

Loral plate. Plate between eye and nostril of a serpent, before and below preocular when this is present; its longest diameter horizontal.

Lores. Space between eye and bill.

Lunate. Form of the new moon; having a broad and rather shallow fork.

M.

Mammary Glands. Glands secreting milk.

Mandible. Under jaw (or in birds either jaw).

Maxilla or maxillary. Upper jaw.

Maxillaries. Outermost or hindmost bones of the upper jaw in fishes; they are joined to the premaxillaries in front and usually extend further back than the latter.

Melanism. State of colouration arising from excess of dark pigment; a frequent condition of hawks.

Membrane. Soft skinny covering of the bill of some birds.

$12 \mathrm{~F}$. 
Mesethmoid. Synonym of ethmoid.

Mesopterygoid. A bone of the suspensorium.

Metacarpus. The hand proper exclusive of the fingers.

Metamorphosis. A decided change in form.

Metapterygoid. A bone of the suspensorium, or chain supporting the lower jaw.

Metatarsus. The foot proper.

Molars. The grinding teeth; posterior teeth in the jaw.

Monogamous. Pairing; said of birds.

Muciferous. Producing or containing mucus.

Myocomma. A muscular band.

Myodome. Cavity under the brain for the reception of the rectus muscles of the eye.

N.

Nape. Upper part of neck, next to the occiput.

Nares. Nostrils, anterior and posterior.

Nasal. Pertaining to the nostrils.

Nasal plate. Plate in which the nostrils are inserted.

Neural arch. An opening through the base of the neural spine, for the passage of the spinal cord.

Neural canal. The neural arches as a whole.

Neural processes. Two plates rising vertically, one on each side of the centrum of the vertebra, which unite toward their ends and form a spine.

Neural spine. The uppermost spine of a vertebra.

Nictitating membrane. The third or inner eyelid, of birds, sharks, etc.

Notochord. A cellular cord, which in the embryo precedes the vertebral column.

Nucha. The upper part of the hind neck, next the hind head.

Nuchal. Pertaining to the nape or nucha.

o.

Obscure. Scarcely visible.

Obsolete. Faintly marked; scarcely evident.

Obtuse. Blunt.

Occipital. Pertaining to the occiput.

Occipital condyle. That part of the occipital bone modified to articulate with the atlas.

Occipital plates. Plates on the head of a serpent, behind the vertical plate. Occiput. Back of the head.

Ocellate. With eye-like spots, generally roundish and with a lighter border. 
Oid (suffix). Like; as Percoid, perch-like.

Opercle, or operculum. Gill cover; the posterior membrane bone of the side of the head, in fishes.

Opercular bones. Membrane bones of the side of the head, in fishes.

Opercular flap. Prolongation of the upper posterior angle of the opercle, in Sun-fishes.

Opisthocœlian. Concave behind only; said of vertebræ which connect by ball and socket joints.

Opistholic. A bone of the skull to which the lower limb of the post-temporal usually articulates.

Orbicular. Nearly circular.

Orbit. Eye socket.

Oscine. Musical.

Oscines. A group of singing birds.

Osseous. Bony.

Ossicula auditus. Bones of the ear in fishes.

Osteology. Study of bones.

Oviparous. Producing eggs which are developed after exclusion from the body, as in all birds and most fishes.

Ovoviviparous. Producing eggs which are hatched before exclusion, as in

Ovum. Egg. the Dogfish and Garter Snake.

P.

Palate. The roof of the mouth.

Palatines. Membrane bones of the roof of mouth; one on each side, extending outward and backward from the vomer.

Palmate. Web-footed; having the anterior toes full-webbed.

Palustrine. Living in swamps.

Papilla. A small, fleshy projection.

Papillose. Covered with papillæ.

Paragnathous. Having the two mandibles about equal in length.

Parasitic. Living on, or deriving nourishment from some other living thing. Habitually making use of other birds' nests.

Parapophyses. The lateral projections on some of the abdominal vertebræ to support ribs.

Parasphenoid. Bone of roof of mouth behind the vomer. Synonym of prefrontal.

Paratoid. A glandular body behind the ear in Batrachians.

Parietal. Bone of the side of the head above.

Parotic process. A posterior lateral process of the skull formed by the pterotic and opiosthotic.

Pectinate. Having teeth like a comb.

Pectoral. Pertaining to the breast. 
Pectoral fins. The anterior or upermost of the paired fins, in fishes corresponding to the anterior limbs of the higher vertebates.

Pelage. The hair of a mammal taken collectively.

Pelagic. Living on or in the high seas.

Pelvic girdle. The bones supporting the ventral fins or pelvics.

Pelvis. The bones to which the hinder limbs (ventral fins in fishes) are attached.

Perforate. Pierced through; said of nostrils when without a septum.

Perissodactylous. Odd toed (toes I, 3 or 5 ).

Peritoneum. The membrane lining the abdominal cavity.

Phalanges. Bones of the fingers and toes.

Pharyngeal bones. Bones behind the gills and at the beginning of the œsophagus of fishes, of various forms, almost always provided with teeth; usually one pair below and four pairs above. They represent a fifth gill arch.

Pharyngobranchials. Upper elements of the branchial arches usually bearing teeth.

Pharyngonathous. Having the lower pharyngeal bones united.

Physoclistous. Having the air bladder closed.

Physostomous. Having the air bladder connected by a tube with the alimenatry canal.

Pigment. Colouring matter.

Pineal body. A small ganglion in the brain; a rudiment of an optic lobe, which in certain lizards (and in extinct forms) is connected with a third or median eye.

Pituitary body. A small ganglion in the brain.

Planta. Sole of foot.

Plastron. Lower shell of a turtle.

Plicate. Folded, showing transverse folds or wrinkles.

Plumage. The feathers of a bird taken collectively.

Plumbeous. Lead-coloured; dull bluish gray.

Pollex. Thumb; in birds the digit which bears the alula-corresponding to the index finger.

Polygamous. Mating with more than one female.

Postclavicle. A ray composed of one or two bones attached to the inner upper surface of the clavicle and extending downward.

Post-frontal (plates). The ones before the vertical plate.

Post-orbital. Behind the eye.

Post-temporal. The bone, in fishes, by which the shoulder girdle is suspended to the cranium.

Prœcoces. Birds able to run about and feed themselves at once when hatched.

Prœcocial. Having the nature of prœcoces.

Procoracoid. A portion of coracoid more or less separated from the rest.

Prœcoracoid arch. An arch in front of the coracoid in most soft-rayed fishes. 
Prefrontal (plates). Those in front of post-frontal.

Premaxillaries. The bones, one on either side, forming the front of the upper jaw in fishes. They are usually larger than the maxillaries and commonly bear most of the upper teeth.

Premolars. The small grinders; the teeth between the canines and the true molars.

Preocular. Before the eye.

Preopercle. The membrane bone lying in front of the opercle and more or less nearly parallel with it.

Preorbital. The large membrane bone before the eye in fishes.

Primary. Any one of the large stiff quills growing upon the pinion or hand bones of a bird (usually nine or ten, sometimes eleven in number); as distinguished from the secondaries, which grow upon the forearm.

Primary wing coverts. The coverts overlying the base of the primaries.

Procœlian. Concave in front only.

Procurrent (fin). With the lower rays inserted progressively farther forward.

Projectile. Capable of being thrust forward.

Prootic. A bone forming an anterolateral ossification of the brain-case.

Protractile. Capable of being drawn forward.

Proximal. Nearest.

Pseudobranchia. Small gills developed on the inner side of the opercle, near its junction with the preopercle.

Pterotic. A bone at the posterior lateral process of the skull.

Pterygoids. Bones of roof of mouth in fishes, behind the palatines.

Pubic bones. Same as pelvic bones.

Pubis. Anterior lower part of pelvis.

Pulmonary. Pertaining to the lungs.

Punctate. Dotted with points.

Pyloric caca. Glandular appendages in the form of blind sacs opening into the alimentary canal of most fishes at the pylorus or passage from the stomach to the intestine.

\section{Q.}

Quadrate. Nearly square; a bone of the lower jaw in lower vertebrates. Quill. One of the stiff feathers of the wing or tail of a bird.

Quincunx. Set of five arranged alternately, thus :-:

R.

Radius. Outer bone of forearm.

Ray. One of the cartilaginous rods which support the membrane of the fin of a fish. 
Rectrices. Quills of the tail of a bird.

Recurved. Curved upward.

Remiges. Quills of the wing of a bird.

Reticulate. Marked with a network of lines.

Retractile. Susceptible of being drawn inward, as a cat's claw.

Retrorse. Turned backward.

Rachis. Shaft of a quill.

Rectal. Pertaining to the rectus, as rectal bristles.

Rectuj. Gape of the mouth.

Rostral. Pertaining to the snout, as rostral plate.

Rudimentary. Undeveloped.

Ruff. A series of modified feathers.

Rugose. Rough, with wrinkles.

Sacral. Pertaining to the sacrum, or vertebræ of the pelvic region.

Saggitate. Shaped like an arrow head.

Saurognathous. Having the peculiar "lizard-like" structure of the palate found in Woodpeckers.

Scansorial. Capable of climbing.

Scansorial tail. Tail feathers sharp and stiff, as in the scansorial birds (Woodpeckers).

Scapula. Shoulder blade; in fishes, the bone of the shoulder girdle below the post-temporal.

Scapulars. Long feathers rising from the shoulders and cuvering the sides of the back.

Scapular arch. Shoulder girdle.

Schizognathous. Split palate, as in the Heron and similar birds.

Scute. Any external bony or horny plate.

Scutellate. Provided with scutella; said of the tarsus when covered with broad plates in a regular vertical series, and separated by regular lines of impression.

Scutellum. One of the tarsal plates or scutella.

Secondaries. The quills growing on the forearm.

Secondary coverts. The wing feathers which cover the bases of the secondary quills.

Second dorsal. The posterior or soft part of the dorsal fin, when the two parts are separated.

Sectorial tooth. One of the premolars of carnivora, adapted for cutting.

Semipalmate. Half-webbed; having the anterior toes more or less connected at base by a webbing which does not extend to the claws.

Septum. A thin partition.

Serrate. Notched like a saw.

Sessile. Without a stem or peduncle. 
Setaceous. Bristly.

Setiform. Bristle-like.

Shaft. Stiff axis of a quill.

Shoulder girdle. The bony girdle posterior to the head, to which the anterior limbs are attached (post-temporal, scapula, and coracoid or clavicle).

Soft dorsal. The posterior part of the dorsal fin in fishes, when composed of soft rays.

Soft rays. Fin rays which are articulate and usually branched.

Spatulate. Shaped like a spatula.

Speculum. A brightly coloured spot of the secondaries, especially of ducks.

Sphenoid. Basal bone of skull.

Sphenotic. A lateral bone of the skull.

Spine. Any sharp projecting point; in fishes those fin rays which are unbranched, inarticulate, and usually, but not always, more or less stiffened.

Spinous. Stiff or composed of spines.

Spinous dorsal. The anterior part of the dorsal fin, when composed of spinous rays.

Spiracles. Openings in the head or neck of some fishes and Batrachians.

Spurious quill. Said of the first primary when less than about one-third the length of the second. The student will notice that in Oscines the presence of a short or spurious quill indicates ten primaries, its absence nine.

Stellate. Star-like, with radiating ridges.

Sternal fontanel. A pit at the top of the sternum.

Sternum. The breast-bone.

Striate. Striped or streaked.

Sub (in composition). Less than; somewhat; not quite; under, etc.

Sub-caudal. Under the tail.

Subopercle. The bone immediately below the opercle (the suture connecting the two often hidden by scales).

Sub-orbital. Below the eye.

Sub-orbital stay. A bone extending from one of the sub-orbital bones in certain fishes, across the cheeks, to or towards the preopercle.

Subulate. Awl-shaped.

Suffrago. Heel joint; joint of tibia and tarsus.

Supraciliary. Pertaining to the region of the eyebrow.

Supplemental maxillary. A small bone lying along upper edge of the maxillary.

Supraclavicle. A bone interposed between the clavicle and the post-temporal.

Supraoccipital. The bone as the posterior part of skull in fishes usually with a raised crest above.

Supra-oral. Above the mouth. 
Supra-orbital. Above the eye.

Supra-scapula. The post-temporal or bone by which the shoulder girdle in fishes is joined to the skull.

suspensorium. The chain of bones from the hyomandibular to the rala. tine.

Suspensory bones. Bones by which the lower jaw, in fishes, is fastened to the skull.

Suture. The line of union of two bones, as in the skull.

Symphysis. Point of junction of the two parts of lower jaw; tip of chin.

Symplectic. The bone in fishes that keeps together the hyomandibular and quadrate posteriorly.

Syndactyle. Having two toes immovably united for some distance, as in the Kingfisher.

Synonym. A different word having the same or a similar meaning.

Synonomy. A collection of different names for the same group, species, or thing.

T.

Tail. In mammals, the vertebræ, etc., posterior to the sacrum; in birds the tail feathers or rectrices, taken collectively; in serpents, the part of the body posterior to the vent; in fishes (usually) the part of the body posterior to the anal fin.

Tail coverts. The small feathers overlapping the bases of the rectrices.

Tarso-metatarsus. The correct name of the so-called tarsus of birds; the bone reaching from the tibia to the toes, composed chiefly of the metatarsus, but having at its top one of the small tarsal bones confluent with it.

Tarsus. The ankle bones collectively; in birds commonly used for the shank bone, lying between the tibia and the toes, the tarso-metatarsus.

Tectrices. The wing and tail coverts.

Temporal. Pertaining to the region of the temples.

Tenuirostral. Slender billed.

Terete. Cylindrical and tapering.

Terminal. At the end.

Tertials. The quills attached to the humerus.

Tessellated. Marked with little checks or squares, like mosaic work.

Thoracic. Pertaining to the chest; ventral fins are thoracic, when attached immediately below the pectorals, as in the Perch, the pelvic bones being fastened to the shoulder girdle.

Tibia. Shin-bone; inner bone of leg between knee and heel.

Tomium. Cutting edge of the bill.

Totipalmate. Having all four toes connected by webbing.

Tragus. The inner lobe of the ear; the lobe opposite the auricle.

Transverse. Crosswise. 
Trenchant. Compressed to a sharp edge.

Truncate. Abrupt, as if cut squarely off.

Tubercle. A small excrescence, like a pimple.

Tympanum. Drum of the ear; external in some Batrachia, etc.

Type (of a genus). The species upon which was based the genus to which it belongs.

Type (of a species). The particular specimen upon which the original specific description was based.

Type (locality). The particular place or locality at which the type specimen was collected.

Typical. Of a structure the most usual in a given group.

U.

Ulna. The inner or posterior bone of the forearm.

Ultimate. Last or farthest.

Unguiculate. Provided with claws.

Ungulate. Provided with hoofs.

Unicolour. Of a single colour.

Urosteges. The plates underneath the tail of a serpent.

\section{V.}

Vent. The external opening of the alimentary canal.

Ventral. Pertaining to the abdomen.

Ventral fins. The paired fins behind or below the pectoral fins in fishes corresponding to the posterior limbs in the higher vertebrates.

Ventral plates. In serpents, the row of plates along the belly between throat and vent.

Ventricle. One of the thick-walled chambers of the heart.

Versatile. Capable of being turned either way.

Vertebra. One of the bones of the spinal column.

Vertical. Up and down.

Vertical fins. The fins on the median line of the body; the dorsal, anal and caudal fins.

Vertical plate. Central plate on the head of a serpent.

Villiform. Said of the teeth of fishes when slender and crowded into velvety bands.

Viscous. Slimy.

Viviparous. Bringing forth living young.

Vomer. In fishes, the front part of the roof of the mouth; a bone lying immediately behind the premaxillaries.

$13 \mathrm{~F}$. 
W.

Web. The vane of a feather, on either side of the rhacis, or "stem"; also the membrane connecting the toes.

$\mathbf{X}$.

Xiphisternum. Tip of the sternum.

Z.

Zygapophyses. Points of bone affording to the vertebræ more or less definite articulation with each other.

Zygodactyle. Yoke-toed; having the toes in pairs, two in front, two behind.

Zygoma. The malar or cheek bone. 


\section{Batrachians and Reptiles of Ontario}

\section{Class BATRACHIA. (The Batrachians.)}

Animals of this class are cold-blooded vertebrates, intermediate between the fishes and the reptiles. They differ from the fishes in the absence of rayed fins, the limbs being usually developed and functional with the skeletal elements of the limbs of reptiles.

The Batrachians undergo a more or less complete metamorphosis; the young (commonly known as "tadpoles") being fishlike and more or less aquatic, breathing by means of external gills. These differ from the gills of fishes in standing on fleshy processes of the branchial bones and not on the bones themselves.

In the tadpole, the tail is provided with a more or less distinct finlike membrane, which usually disappears with age. Later in life, lungs are developed, and in most cases the gills disappear. Skin mostly naked and moist; used to some extent as an organ of respiration.

In our species reproduction is by means of eggs, which are of comparatively small size and without hard shell. These are deposited in water or in damp places.

No representative of this class found in Canada is venomous, or indeed capable of inflicting injury upon human beings; while many species are of economic importance, the Toads and Tree Frogs (Hylas) being particularly valuable as destroyers of noxious insects.

\section{Order PROTEIDA.}

\section{Family PROTEID}

Salamanders provided with bushy external gills and having the branchial clefts remaining open through life. Teeth well developed.

\section{Genus NECTURUS.}

(I) Necturus maculosus.

\section{(Mud Puppy.)}

This species is provided with large bushy bright red gills, forming three tufts on each side. These gills are retained through life. It is 
aquatic in all stages. Common throughout Ontario. Feeds upon aquatic insects and small fish.

In hatcheries or fish ponds it would be decidedly injurious, as it is a very voracious creature.

\section{Order URODELA. (The Salamanders.)}

Body naked, elongate. subterete; both jaws with teeth. Tail persistent through life; no external gills in the normally developed adult.

\section{FAMILY AMBLYSTOMATID E.}

Toes not webbed; tongue thick.

The larvæ of Amblystoma often reach a large size before the gills disappear, and sometimes breed while in this condition.

\section{Genus AMBLYSTOMA.}

(2) Amblystoma punctatum.

(Spotted salamander.)

Common and generally distributed in the southern counties. Feeds upon insects and earthworms.

\section{(3) Amblystoma tigrinum.}

Of this species I have but a few records for Ontario. It is common in the United States as far north as Minnesota, and will probably be found generally in the northern part of the Province.

\section{(4) Amblystoma Jeffersonianum.}

(Granulated salamander.)

This species and the variety $A$. j. fuscum have been taken occasionally in western Ontario and also near Toronto.

\section{(5) Amblystoma microstomus.}

There is a specimen of this species in the U. S. Nat. Mus., taken at Hudson's Bay in 1884 , which is the only record I have of its occurrence in Canada. I include it because it will probably be found in northern Ontario.

\section{Family PLETHODONTIDA.}

\section{Genus HEMIDACTYLIUM.}

(*) (6) Hemidactylium scutatum.

A specimen of this species was taken by Dr. D. W. Beadle at St. Catharines, Ont. The only record I have. 


\section{Genus PLETHODON.}

(7) Plechodon cinereus.

(Red-backed salamander.)

Its habits are entirely terrestrial as it is never, even in the larval stage found in water. The eggs are deposited in a little package beneath a stone, in a damp place. When the young emerge they are provided with branchiæ, but these soon disappear.

Common everywhere and may be readily found by turning over $\log$ s or stones in the woods.

\section{FAMILY DESMOGNATHID $Æ$.}

\section{Genus DESMOGNATHUS.}

(8) Desmognathus fusca.

Rare; has been taken in south-western Ontario. Aquatic.

(*) (9) Desmognathus nigra.

(Black salamander.)

Rare; occurring in shallow stony brooks.

\section{Family PleURodelid}

\section{Genus DIEMYCTYLUS.}

(10) Diemyctylus viridiscens.

(Newt. Evet. Eft.)

Common; generally distributed through southern Ontario.

Of this species there are two distinct forms, one entirely aquatic, dark olive green above, lemon yellow below, and having on each side a row of rather large vermillion spots each surrounded by a black ring. The other and better known one, being the little red lizard (so called) which is frequently found in woods after rain. The red coloration is only assumed if the animal leaves the water and adopts terrestrial habits and is again lost when it returns to the water.

The red form was for a long time considered a distinct species and has been frequently described as D. mineatus.

\section{Order SALIENTIA. (The Tailless Batrachians.)}

In the adults the body is broad and short; the hinder pair of limbs long and strong, adapted for leaping. Tail absent. The young (Tadpoles) have the head broad, external branchiæ, a long tail, no limbs and no teeth; the intestinal canal is very long, adapted to a vegetable diet. As they develop the tail is absorbed and the legs gradually appear. During this stage they are entirely aquatic, but upon attaining mature 
form the Toads and Hylas leave the water, only returning to it for the purpose of depositing their eggs. The Ranidæ (Frogs) are more or less aquatic when adult.

\section{Family BUFONIDA. (The Toads.)}

\section{Genus BUFO.}

\section{(I I) Bufo leutiginosus.}

(American Toad.)

The form found in Ontario is B. 1. americanus. Common every, where. Unfortunately it is the victim of ignorance and prejudice and is often wantonly destroyed because of its somewhat unprepossessing appearance. From an agricultural standpoint, however, it is one of the most valuable animals we have and should be protected with the greatest care.

By the ignorant and superstitious the Toad is supposed to be possessed of some very remarkable powers; thus even in this age of progress we hear of the ability of the Toad to spit poison; to produce warts on the hands of persons who handle it ; to poison children by its breath, and several other dreadful things. On the other hand, it is credited with bringing good luck to the family in whose cellar it takes up its abode. It is also said that the application of living Toads to cancer will effect a permanent cure, and that the animal carries a most valuable jewel in its head. All of which is false and ridiculous. Toads are perfectly harmless, though the skin does secrete a peculiar fluid which is distasteful to dogs, but not so to birds, and many other animals, for they feed upon them largely.

The Toad is of direct service to man by reason of the fact that its food consists of insects exclusively and that it is one of the few animals which can adapt itself alike to the farm and garden and will even be perfectly contented if confined in a greenhouse or propagating frame.

\section{Family HYLID E. (THe Tree Frogs.)}

Fingers and toes more or less dilated into viscous disks at their tips. Noted for their loud voices, some of them being heard at all times from early spring until frost comes.

\section{Genus ACRIS.}

\section{(I 2) Acris gryllus.}

(Cricket Frog.)

The Ontario form is A. g. crepitans. This can scarcely be considered a Tree Frog. Its home is in the high grasses surrounding the marsh, where, if disturbed, it can take refuge in the water. 


\section{Genus CHOROPHILUS.}

\section{(*) (13) Chorophilus nigritus.}

(Swamp Tree Frog.)

The variety found here is C. n. triseriatus. It occurs on the north shore of Lake Superior and westward into Manitoba, but I have no records of its capture in any other part of Canada.

\section{Genus HYLA.}

\section{( I 4) Hyla versicolor.}

(Common Tree Frog.)

A common and very useful species, well distributed throughout the Province of Ontario. I found it also in Manitoba, but it does not appear to be abundant there.

It deposits its eggs in the spring on blades of grass, etc., in shallow water, and the metamorphosis takes place quite early, the tadpoles rarely exceeding in size those of the Common Toad.

This frog possesses the power of changing its colour to suit its environment to a certain extent, the colours running through various shades of green, brown and grey. Amongst leaves or grass the animal will be green. On a lichen covered fence or log it will be brown. The change in colour is not effected very rapidly, but is gradual.

In the summer the voice of these frogs is continually heard towards evening and in dull weather, from the orchard and wood lot and sometimes from the rail fences by the roadside.

\section{( 5$)$ Hyla pickeringii.}

\section{(Pickering's Hyla.)}

Though this small tree frog is abundant everywhere in southern Ontario, it is but very seldom seen. Its diminutive size and secretive habits render it very difficult to observe, though its shrill piped notes are among the most noticeable sounds of spring; for it is this little creature which utters the loud "peep" heard in the swamps just as the ice goes out. This note is quite often attributed to a lizard or a turtle by people who have the bad habit of guessing at things.

Late in the summer this Hyla leaves the swamps and ascends the trees and bushes on higher ground and again becomes musical.

\section{Family RANID $\approx$. (The Frogs.)}

\section{Genus RANA.}

\section{(16) Rana areolata.}

A rare frog. R. a. circulosa, the northern variety, should be more abundant. It has probably been overlooked. 
(i7) Rana pipiens.

(Leopard frog.)

The commonest species, abundant in marshes and wet meadows. It is generally distributed, but the northern limit of its range in our Province is uncertain.

\section{(18) Rana palustris.}

(Pickerel Frog.)

Common and generally distributed. In its habits it is solitary. It is often found about cold springs and streams and sometimes ranges into meadows for food.

(19) Rana septentrionalis.

(Northern Frog.)

The range of this species in Ontario extends from the County of Bruce northward and westward. Not common.

(20) Rana sylvatica.

(Wood Frog.)

This frog is scarcely aquatic. It lives in the woods throughout the summer and rarely if ever visits water except during the breeding season. Like the Hylas, it is susceptible to the colour of its surroundings and is said to change from the tan colour of a dead leaf to the green of a living one with ease.

\section{(21) Rana cantabrigensis.}

A similar species to the last, of which it was formerly considered a. variety. It ranges as far north as Hudson's Bay.

\section{(22) Rana clamitans.}

(Green Frog.)

An entirely aquatic species, rarely seeking food on land. It has no. spring love notes and the tadpoles require two years in which to mature.

Common in all bodies of water, but perhaps more partial to springs: and streams than marshes.

\section{(23) Rana catesbeana.}

\section{(Bull Frog.)}

The largest of our frogs. Common in marshes and slow weedy streams. They have no spring love notes, but their sonorous bass summer voice is recognized by everybody. The tadpoles require two years to mature.

Generally distributed. Valued as an article of food. It is from this species that the much esteemed "frogs' legs" are usually obtained. 


\section{Class REPTILIA. (The Reptiles.)}

The Reptiles are cold blooded air-breathing vertebrates, usually scaly or covered with bony plates. The limbs when present, are usually adapted for walking, in some few instances for swimming.

Repro uction viviparous, oviparous or ovoviviparous. The eggs of the oviparous species are mostly provided with a tough leathery skin and are deposited in holes dug in the earth or amongst decaying vegetable matter. There is no metamorphosis after leaving the egg.

Reptiles may be distinguished from Batrachians by the presence of scales and by the absence of gills in all stages.

\section{Order OPHIDIA. (The Serpents.)}

Reptiles with elongate, cylindrical bodies, no limbs. The skin, which is covered with imbricated scales, is shed at intervals. The mouth is very dilatable, the bones of both jaws being freely movable.

But very little is positively known as to the reproduction of any of our snakes and so a wide field is open for work and observation.

The majority of people believe that all snakes are poisonous and should therefore be destroyed. Such belief is largely the result of ignorance combined with prejudice. The only injurious animals of this class we have are Rattlesnakes, and they are now extremely scarce and local. All our other snakes are useful. feeding upon and thus destroying vast numbers of such pests as mice, voles and injurious insects, and consequently should be allowed to live unmolested.

\section{Family COlubrid $Æ$. (The Colubrine Snakes.)}

Both jaws fully provided with teeth, which are conical and not grooved; head covered with shields; no poison fangs; belly covered with broad band-like plates (ventral plates or gastrosteges); tail conical, tapering; sub-caudal plates (urosteges) arranged in pairs. All our species are quite incapable of inflicting serious injury upon man or beast and most of them are beneficial by reason of their destruction of insects and field mice.

GENUS STORERIA.

\section{(1) Storeria occipitomaculata.}

(Red-bellied Snake.)

No uncommon. Feeds largely upon soft bodied insects. Perfectly inoffensive. A useful species.

(2) Storeria dekayi.

(Little Brown Snake.)

Quite common and generally distributed. Feeds upon insects and their larvæ. Perfectly inoffensive. A useful species. 


\section{Genus ThamNophis. (Garter Snakes.)}

\section{(3) Thamnophis sauritus.}

(Riband Snake.)

Not very common, apparently occurring more frequently in the eastern part of the Province than in the west. A very beautiful, harmless creature. Feeds upon insects, small toads and frogs.

\section{(4) Thamnophis radix.}

(Hoy's Garter Snake.)

Occurs in western Ontario and may be generally distributed, though not abundant anywhere. Harmless. Feeds upon toads, frogs, insects and field mice.

\section{(5) Thamnophis sirtalis.}

(Common Garter Snake.)

Abundant and generally distributed. This is considered the typical Garter Snake. It is an exceedingly variable species, scarcely any two being exactly alike in coloration.

When molested I have sometimes seen this snake show fight, but it is incapable of inflicting any injury more serious than a slight scratch, from which no bad results need be feared. Its food consists of toads, frogs, mice and insects.

Formerly a great many varieties or sub-species of this species were recognized; of late, however, the number has been considerably reduced. The most prominent varieties occurring here are:-

(5a) T. s. odinatus-Tolerably common.

(5b) T. s. dorsalis-Very common.

(5c) T. s. parietalis-Not common.

(5d) T. s. obscurus-Occasional.

As all these intergrade perfectly with each other and with the type form, their identification is sometimes rather difficult.

\section{GENUS REGINA.}

(*) (6) Regina rigida.

(Stiff Snake.)

Very rare; the only available record is from Lake St. Clair.

(7) Regina leberis.

(Leather Sriake.)

Occurs in the same locality as the last, but is even more uncommon. 
(8) Natrix sipedon.

\section{Genus NATRIX.}

(Water Snake.)

Common about streams throughout Ontario. When molested this creature shows fight and makes strenuous efforts to bite its tormentor. It is, however, perfectly harmless. It swims well and rapidly and feeds on frogs and small fish.

\section{Genus CALLOPELTIS.}

(9) Callopeltis vulpinus.

(Fox Snake.)

This is the largest and strongest of all our snakes and at the same time one of the most harmless and timid. It does not appear to be common anywhere, but is generally distributed through the western part of Ontario from the Niagara Peninsula to the Georgian Bay, and probably somewhat further north.

Dr. Garnier records one which measured seven feet eleven inches and I have seen several nearly as large.

(10) Liopeltis vernalis.

\section{Genus LIOPELTIS.}

(Green Snake, Grass Snake.)

A very gentle, beautiful, little creature. Common and generally distributed. It feeds largely if not entirely upon soft-bodied insects and is therefore of economic value.

\section{Genus BASCANION.}

\section{(1) Bascanion constrictor.}

\section{(Black Snake, Black Racer.)}

I include this species, though I am in doubt as to its occurrence in this Province. Many years ago, I believe that I found the true Black Snake in western Ontario, but preserved no specimens. Of late years all the so-called Black Snakes examined by me have proved to be the Common Water Snake (Natrix sipedon).

This species is very active and strong, but is perfectly harmless. Its food consists principally of voles and mice, of which it destroys large numbers. Professor Cope says of it: "Of all our snakes it is the most useful to the farmer from the great number of moles and mice which it consumes." Florida.

There is a specimen of this snake in the Museum, but it was taken in

(12) Diadophis punctatus.

\section{(Ring Snake.)}

A small, tolerably common species, which feeds largely upon beetles and soft-bodied insects. Generally distributed and very inoffensive. 


\section{GENUS LAMPROPELTIS.}

\section{(13) Lampropeltis doliatus.}

(Milk Snake, Spotted Adder.)

This is a very variable species, its varieties running by degrees into extremes, which bear little resemblance to the type form.

The northern variety, which is very common and generally distributed through this Province, is L. d. triangulus.

It is very harmless and useful, feeding largely on field mice and voles. Prof. Cope says he once found a specimen of this species which had captured a family of meadow mice, which it held in the following manner: One it had swallowed. one it was in the act of swallowing, and two others were securely held in two turns of its body so tightly as to render them incapable of biting their captor. They also feed to a certain extent upon frogs and toads and in so doing lessen their economic value slightly, but on the whole they are decidedly beneficial to the farmer and should be protected.

\section{Genus HETERODON.}

\section{(14) Heterodon platirhinos.}

(Blowing Adder, Spreading Adder.)

Not common, though generally distributed. When teased this snake depresses and expands its head, hissing and presenting a threatening appearance, causing many people to believe it to be venomous, but it is quite harmless. Its food consists largely of mice, frogs and toads. Occasionally very dark, almost black, specimens are found.

\section{Family CROTALid $\AA$. (The Rattlesnakes.)}

The species comprised in this family are the only poisonous snakes occurring in Ontario and they are now very rare in all parts of the Province except some few restricted localities near Lake Erie and the Georgian Bay. When the country was first settled they were common enough, particularly so in rocky regions. The banks of the Niagara River and the face of what is known as the Hamilton mountain having been, formerly, among their favorite resorts. The introduction of pigs into the country was probably one of the chief factors in the destructon of these dangerous creatures. For. as is well known, pigs can kill and eat Rattlesnakes with impunity. It is supposd that the poison of the snake cannot be sufficiently introduced into the circulation to cause death owing to the thick layer of fat with which the domesticated pig is covered.

There is a common, but erroneous. idea, that one new segment is added to the number on a Rattlesnake's tail each year. The fact is the number varies, as many as four have been observed to be acquired in a single year. The terminal segments, too, are constantly being worn off, so that the number of segments present is no indication of the age of the snake. 
These snakes can only strike a distance equal to about one-half the length of the body. They need not necessarily be coiled to strike, for this they can do on either side, as far as the position of the body will permit them to reach.

Rattlesnakes are ovoviviparous and not very prolific. Prof. Cope found nine eggs in the body of a female thirty-seven inches long.

The Rattlesnakes may be distinguished from all other Canadian snakes by the following well marked characters: Maxillary without solid teeth, but provided with a long erectile, perforated poison fang on each side in front; a deep pit between eye and nostril. Body stout; head large, flat, triangular, on a slender neck; pupil elliptical, placed vertically. Tail provided with a rattle composed of horny rings, which are modified scales.

\section{GENUS SISTRURUS.}

\section{(15) Sistrurus catenatus.}

(Prairie Rattlesnake.)

This species formerly occurred in the meadow lands at the western end of Lake Erie, and has been found from there north to the Georgian Bay. It is now nearly extinct. Though its bite is very dangerous and may cause death, its venom is not so powerful as that of the next.

\section{GENUS CROTALUS.}

\section{(i6) Crotalus horridus.}

(Common Rattlesnake.)

Formerly common and generally distributed throughout the Province, but always most abundant in rocky places. Now nearly extinct. Very venomous.

\section{Order LACERTILIA. (The Lizards.)}

This order is poorly represented in Ontario, only three species as yet having been found in the Province, and these all belong to one genus.

The characteristics of animals belonging to this order are : body covered with scales; limbs four, distinct, rarely rudimentary. Tail usually long and in many cases very brittle, easily broken by a slight blow, or if the animal is held by it. Tongue free; jaws always with teeth; mouth not dilatable; toes having claws.

\section{Family SCINCIDAE. (The Skinks.)}

Head regularly shielded, scales smooth, body fusiform or sub-cylindrical. All the species are quite harmless and feed upon insects. They are fond of basking in the sun and rarely show themselves unless the weather is bright and warm.

So far as is known at present, all our species are ovoviviparous. 


\section{Genus EUMECES.}

(16) Eumeces fasciatus.

(Blue-tailed Lizard.)

This variable species seems to be generally distributed throughout the Province, though not abundant anywhere. Specimens have been taken in the County of Peterboro', in Lincoln, and in most of the south-western counties. It is very active in hot weather. Feeds upon insects and is perfectly harmless.

\section{(*) (I7) Eumeces anthracinus.}

\section{(Coal Skink.)}

The only records I have of this species, are Dr. Garnier's, his specimens having been taken in the County of Kent.

\section{(*) (18) Eumeces septentrionalis.}

(Northern Skink.)

This species has a wide distribution northward. Dr. Garnier found it in southern Ontario and there are specimens in the U. S. Nat. Museum from the Red River of the North. It should therefore be found in all suitable places in the western part of the Province.

\section{Order TESTUDINATA. (The Turtles.)}

Reptiles with the body enclosed between two, more or less developed, bony shields, which are usually covered by horny epidermal plates, but sometimes by a leathery skin. Upper shield (carapace) and lower shield (plastron) more or less united along the sides.

Neck and tail the only flexible parts of the spinal column; these, together with the legs, usually retractile within the cavity between the two shields.

The skull is more compact than that of the other reptiles. There are no teeth, but the jaws are encased in horny sheaths, usually with sharp cutting edges; the eye is furnished with two lids and a nictitating membrane as in birds.

All our species are oviparous, depositing their eggs in hollows which they dig in the soil near water. The eggs are then covered with the earth or sand and left to hatch.

\section{Family TRIONYCHid $\approx$. (The Soft-Shelled Turtles.)}

Body flat, nearly circular; carapace and plastron covered by a thick leathery skin which is flexible at the margins. Head long and pointed, with a flexible tubular pig-like snout, neck long. Feet broadly webbed. Aquatic and carnivorous, feeding upon fish, frogs, etc. 
(") (19) Amyda mutica.

\section{Genus AMYDA.}

(Leather Turtle.)

Tli is species has been recorded from Lake Erie and from thence west. ward. It is considered very rare but may often be confounded with the next.

\section{GENUS ASPIDONECTES.}

(20) Aspidonectes spinif̂er.

(Common Soft-shelled Turtle.)

Generally ditributed in all marshy waters in western Ontario, though not common anywhere. There is one record from the Ottawa River. The creature is shy and difficult to observe, and so may occur more frequently and over a greater area than is supposed. I have found it from our western boundary to the head of Lake Ontario, near Hamilton, but none east of that.

The flesh of this Turtle is considered a delicacy.

\section{Family CHElydRid $A$. (Snapping Turtles.)}

Shell high in front, low behind; body heaviest forward; head and neck large, the snout narrowed forward; jaws strongly hooked and very powerful; tail long, strong, with a crest of horny compressed tubercles; plastron small, cross shaped; claws strong; webs small. Aquatic, rarely leaving the water except to deposit their eggs.

\section{(2I) Chelydra serpentina.}

\section{Genus CHELYDRA.}

(Snapping Turtle.)

Common and generally distributed throughout the Province. This is undoubtedly the most powerful, aggressive and voracious reptile we have. It feeds upon any living thing it can overpower and is particularly destructive to fish and young waterfowl. Many a brood of young ducks find their way down the capacious gullets of these rapacious creatures. They attain a great size, specimens over two feet in length being not uncommon. Care is required in handling these Turtles, for even when comparatively small they will bite viciously and are capable of inflicting painful wounds.

Their flesh is considered good and in some localities they are much sought after for making into soup.

\section{Family KINOSTERNIDÆ. (The Box Turties.)}

Carapace rather long and narrow, the outline rising gradually from the front to a point beyond the centre of the shell, then abruptly descending; the bulk of the body therefore thrown backward; margin of the carapace turning downward and inward rather than outward; head large with strong jaws. 


\section{GeNus AROMOCHELYS.}

(*) (22) Aromochelys odoratus.

(Musk Turtle.)

This small Turtle is occasionally found in Lake Erie and St. Clair, but it is not common. It has a strong, unpleasant musky odour.

\section{Family EMydid e. (The Pond Turtles.)}

Carapace ovate, broadest behind, the margin having a tendency to flare outwards; highest near the middle; plastron covering the whole under surface. Toes broadly webbed in the aquatic species, scarcely webbed in the others. The pond turtles feed largely upon small fish and consequently would be injurious in preserves and hatcheries.

\section{Genus GRAPTEMYS.}

\section{(23) Graptemys geographicus.}

(Map Turtle.)

This species seems to be peculiarly distributed in the Province. It is not uncommon in the west, and I have received specimens from the County of Lanark in the east, but so far have not seen it in the waters of Lake Ontario.

\section{(24) Chrysemys picta.}

\section{Genus CHRYSEMYS.}

(Painted Turtle.)

The commonest and most beautiful Turtle we have. Hundreds of them may sometimes be seen sunning themselves upon logs and other floating debris in our southern marshes. Aquatic, only leaving the water to deposit its eggs.

\section{Genus CLEMMYS.}

(25) Clemmys insculptus.

(Wood Tortoise.)

Tolerably common in western Ontario, less frequently found eastward. Largely terrestrial.

(26) Clemmys guttatus.

(Speckled Tortoise.)

Common in south-western Ontario. They are usually found in warm mud ponds from which they crawl out to sun themselves in the manner of C. picta.

Genus EMYDOIDEA.

(*) (27) Emydoidea blandingi.

(Blanding's Tortoise.)

Very rare. Dr. Garnier records one specimen taken at Lake St. Clair by Mr. Buck, and others have been taken near Belleville. 


\section{CHECK LIST}

\section{OF THE \\ BIRDS OF ONTARIO.}

AVES (The Birds).

A bird may be defined as an air-breathing vertebrate with a covering of feathers; warm blood; a complete double circulation; the two anteriur limbs (wings) adapted for flying or swimming, the two posterior limbs (legs) apadted for walking or swimming; respiration never effected by gill, or branchiæ, but after leaving the egg by lungs, which are connected with air cavities in various parts of the body. Reproduction by eggs which are hatched externally, either by incubation, or exposure to the heat : the sun; the shell calcareous, hard and brittle.

\section{Order PYGOPODES. (Diving Birds.)}

Feet palmate or lobate; tibia feathered, included in the skin nearly to the heel joint, hence the legs set far back so that the birds are scarcely able to walk at all on land; hind toe small and elevated or wanting; bill horny, not lamellate or serrate; no gular pouch; wings very short; tail very short or rudimentary. All are water birds, expert divers, feeding chiefly on fishas.

\section{Family PODICIPID压 (Grebes).}

Head with crests or ruffs in the breeding season except in Podilym. bus. Under plumage dense, lustrous, mostly white. Wings very short; tail rudimentary, without distinct quills. Feet lobate, toes flattened, provided with flat claws resembling human nails, tarsus scutellate, compressed. All are aquatic.

\section{Genus COLYMBUS.}

(2) Holbœll's Grebe.

(Colymbus holbœlli.)

A regular, but never a common, spring and autumn visitor to the waters of southern Ontario. Probably breeds in the northern part of the Province. 


\section{(3) Horned Grebe.}

(Colymbus auritus.)

Abundant on the great lakes and all large bodies of water throughout the Province in spring and autumn; breeding in the large marshes. A few remain on Lake Ontario through the winter.

\section{Genus PODILYMBUS.}

(6) Pied-billed Grebe. (Hell Diver.)

(Podilymbus podiceps.)

A common summer resident in marshes all over the Province, breeding throughout its range. Arrives early in April, departs about the middle of October.

\section{Family GAVIID A. (The LoONS.)}

Bill long, strong, tapering, acute, wholly hard; nostrils linear. Head densely and evenly feathered, without ruffs or naked spaces; eye large. Feet palmate; tarsus reticulate, strongly compressed; wings strong. Tail short but well developed. Birds of large size, with strong powers of flight and pre-eminent in swimming and diving, but scarcely able to walk. Their notes are curiously loud and wild, according well with their usual surroundings. They feed on fishes.

(7) Loon.

\section{Genus GAVIA.}

(Gavia imber.)

Common on all large bodies of water in spring and autumn, breeding about the lakes and marshes of the interior. Some few remain on the great lakes all through the winter, but the bulk go south during the coldest part of the season.

(*) (9) Black-throated Loon.

(Gavia arctica.)

A very rare winter visitor.

(1 I) Red-throated Loon.

(Gavia lumme.)

A common spring and autumn visitor to our waters, breeding in the far north and retiring southward as its haunts freeze up.

Family AlCid E. (The Auks, Murres, Etc.)

Feet palmate, three-toed; tarsus reticulate or partly scutellate; claws ordinary; tail perfect of few feathers; legs set far back. All our species fly well and swim on, or under water with equal ease. They feed on fishes. 


\section{Genus FRATERCULA.}

(1 3) Puffin.

(Fratercula arctica.)

Common in the Arctic regions and the islands of the North Atlantic. A bird of the ocean. One specimen has been recorded, taken on the Ottawa River.

\section{Genus CEPPHUS.}

(27) Black Guillemot.

(Cepphus grylle.)

Like the last, a bird of the ocean, which occasionally has wandered up to Lake Ontario. Mr. John Maughan, jr., has a specimen taken near Toronto, and Mr. McIlwraith mentions one taken on Burlington Bay many years ago.

\section{GenUs URIA.}

(3I) Brunnich's Murre.

(Uria lomvia.)

Common on the Atlantic coast and an occasional winter visitor to Lake Ontario.

During the winter of 1893 a large number of these birds appeared on Lake Ontario, and each season since that time, a few have been seen there.

\section{Genus ALCA.}

(32) Razor-billed Auk.

(Alca torda.)

Another ocean bird which has found its way up Lake Ontario occasionally in late autumn or early winter.

\section{Genus ALLE.}

(34) Dovekie. (Little Auk.)

(Alle alle.)

Common on some parts of the North Atlantic coast. One specimen taken by Mr. John Maughan on Lake Ontario.

\section{Order LONGIPENNES. (Long=winged Swimmers.)}

Feet palmate; tibia feathered; legs inserted near the centre of equilibrium, so that the birds stand with the axis of the body nearly hori- 
zontal; hind toe small and elevated (wanting in Rissa). Bill usually long. horny, not serrate, nor lamellate; no gular pouch. Wings very long and pointed; tail well developed. Water birds, of great powers of flight; feeding on fishes and floating garbage.

\section{FAMILy STERCORARIIDA. (The JAEgers.)}

Gull-like birds with the bill hooked and cered; tail square with the middle pair of feathers long-exserted; tibia naked below; tarsus scutel. late in front, granular behind. Voracious birds, which frequently live by tormenting the Gulls and Terns and compelling them to disgorge their food. Plumage dark above.

\section{GeNus STERCORARIUS.}

(*) (36) Pomarine Jaeger.

(Stercorarius pomarinus.)

An occasional visitor to the great lakes.

(37) Parasitic Jaeger.

(Stercorarius parasiticus.)

An occasional spring and autumn visitor to the great lakes.

\section{Family LARIDÆ. (The Gulls.)}

Long-winged swimmers. Bill long, horny, not serrate nor lamellate; no gular pouch. Feet palmate; tibia feathered; legs near centre of equilibrium; hind toe elevated, small (wanting in Rissa). Wings very long and pointed. Tail well developed. General colour usually white, with a darker mantle of a slaty bluish tint and commonly some black markings. Sexes alike in colour, but the plumage varying very much with age and season. Possessed of wonderful power of flight. Food, fishes and floating garbage. The birds are the scavengers of the waters.

(*) (39) Ivory Gull.

\section{Genus PAGOPHILA.}

(Pagophila alba.)

A regular but not a common winter visitor to Lake Ontario. It probably occurs on the northern lakes also, but as yet I have not heard of it.

(40) Kittiwake Gull.

\section{GeNus RISSA.}

(Rissa tridactyla.)

A regular, but not common, winter visitor to the great lakes. 
(42) Glaucous Gull.

\section{Genus LARUS.}

(Larus glaucus.)

A regular, but not common, visitor to the great lakes.

(43) Iceland Gull.

(Larus leucopterus.)

Mr. Kay reports having taken one at Port Sydney, Muskoka, April 6th, 1898, and Mr. J. H. Ames has one taken at Toronto.

(47) Great Black-backed Gull.

(Larus marinus.)

A regular, but not abundant, winter visitor to the great lakes, more frequently observed than either of the preceding species, perhaps because it is more readily distinguishable when flying.

(5I) American Herring Gull.

(Larus argentatus.)

A very common resident, frequenting the great lakes at all seasons, but most abundant in winter. It breeds regularly on many of the lakes and marshes of the interior. It formerly bred on the islands and in the marshes of Lake Ontario and some may yet do so, in secluded places.

(54) Ring-billed Gull.

(Larus delawarensis.)

A very common resident; like the last, most abundant in winter. Breeds in the lakes and marshıs of the interior.

(*) (58) Laughing Gull.

(Larus atricilla.)

An accidental visitor in summer

(59) Franklim's Gull.

(Larus franklinii:)

A rare summer visitor, occasionally straggling here from the prairie sloughs where they are abundant. Breeds in nearly all the large marshes of Manitoba.

(60) Bonaparte's Gull.

(Larus philadelphia.)

A common spring and autumn visitor to the great lakes, arriving in April and departing at the end of November. It is possible that some breed in the northern part of the Province, but its principal breeding grounds are north and west of Ontario. 


\section{Subfamily STERninÆ. (The Terns.)}

(64) Caspian Tern.

\section{Genus STERNA.}

(Sterna caspia.) lakes.

A regular but not common spring and autumn visitor to the great

$\left({ }^{*}\right)(67)$ Cabot's Tern.

(Sterna sandvicensis acufluvida.)

The capture of a specimen of this Tern in the spring of 1882 , at Lucknow, is recorded by Mr. McIlwraith.

(6ig) Forster's Tern.

(Sterna fosteri.)

A rather uncommon summer visitor, breeds in the larger marshes throughout its range.

(70) Common Tern.

(Sterna hirundo.)

A regular summer visitor, breeding at several places near the lakes. Not uncommon in spring and autumn.

(74) Least Tern.

(Sterna antillarum.)

An accidental visitor. Breeds on the Atlantic coast. Mr. John Maughan has a specimen, taken at Toronto in 1897 .

\section{GENUS HYDROCHELIDON.}

(77) Black Tern.

(Hydrochelidon nigra surinamensis.)

This Tern is common in some of the large marshes throughout the Province during the summer, but it is not generally distributed. Breeds where it occurs.

\section{Family PROCEllaridd}

Genus ESTRELATA.

(*) (98) Black-capped Petrel.

(Æstrelata hasitata.)

One found dead on the shore of the Island at Toronto. 


\section{Order STEGANOPODES. (The Totipalmate Swimmers.)}

Swimming birds with all four toes fully webbed; hind toe lengthened, scarcely elevated; tibia feathered; bill horny, not lamellate; nostrils very small or abortive; a prominent gular pouch; tarsus reticulate. All our species are large aquatic birds, feeding on fish, of which they consume great quantities.

\section{Family SUlid AE. (The Gannets.)}

Bill long, cleft to beyond eyes, very stout at base, the tip not hooked; the edges irregularly serrate; a nasal groove but the nostril abortive: gular sac small, naked; wings long, pointed; tail long and stiff, with pointed feathers; feet stout. Body heavy, the tissues under the skin with air chambers.

\section{Genus SULA.}

(I 17 ) Gannet.

(Sula bassana.)

An accidental visitor from the Atlantic coast, which has been met with on Lake Ontario three or four times.

\section{Family PHALACROCORACIDA. (The Cormorants.)}

Bill slender, compressed, strongly hooked, the cutting edges uneven; gular pouch small; wings short; tail large, of very stiff feathers, often used to partially support the body; legs set far back; a nasal groove with abortive nostrils.

\section{Genus PHALACROCORAX.}

\section{( I I9) Cormorant.}

\section{(Phalacrocorax carbo.)}

An uncommon spring and autumn visitor to the larger bodies of water. Breeds along the North Atlantic coast.

\section{(120) Double-crested Cormorant.}

(Phalacrocorax dilophus.)

A regular but not a common spring and autumn visitor to our lakes; probably breeds about the waters of the northern part of the Province, as it does commonly in Manitoba and Assiniboia. 


\section{Family PElecanid E. (The Pelicans.)}

Bill very long, straight grooved throughout, with a claw-like hook at the end; the broad space between the branches of the lower mandible occupied by a large membraneous sac; nostrils abortive; wings very long; tail very short; feet short and stout.

\section{Genus PELECANUS.}

(*) (125) American White Pelican.

(Pelecanus erythrorhynchos.)

An accidental visitor to the great lakes. They breed commonly in Northern Manitoba and the Western Provinces.

\section{Order ANSERES. (The Lamellirostral Swimmers.)}

Swimming birds with feet four-toed, palmate, hind toe small, elevated. Bill lamellate; no gular pouch. Legs short.

This order contains nearly all the water-fowl which are valued in domestication, or as game birds.

\section{Family ANATID $Æ$. (Ducks, Geese and Swans.)}

Bill laminate, i.e. furnished along each cutting edge with a regular series of tooth-like processes, which correspond to certain laciniate processes of the fleshy tongue, which ends in a horny tip; bill large, thick, high at base, depressed towards the end, membraneous except at the obtuse tip, which is occupied by a horny nail. Body heavy, flattened beneath. Head high, compressed, with sloping forehead; eyes small. Tail short, except in the full plumaged males of Dafila and Harelda, both of which have the central tail feathers much prolonged. Legs and feet short, the anterior toes full webbed. Tibia feathered. All are good swimmers and, with us, more or less migratory.

\section{Subfamily MERGin E. (The Mergansers.) \\ GeNus MERGANSER.}

(129) American Merganser. (Goosander.)

(Merganser americanus.)

A common resident, breeding in the northern part of the Provinie and spending the winter on the open water of the lakes and rapid rivers near our southern boundary.

These birds are very destructive to our fisheries. 


\section{(130) Red-breasted Merganser.}

(Merganser serrator.)

A common resident, more abundant than the last and equally destructive to fish. Breeds in the interior of the Province and winters wherever there is open water.

\section{Genus LOPHODYTES.}

\section{(131 Hooded Merganser.}

(Eophodytes cucullatus.)

A tolerably common summer resident, breeding throughout the interior of the Province and retiring southward as ice forms.

Subfamily ANatin E. (The River Ducks.)

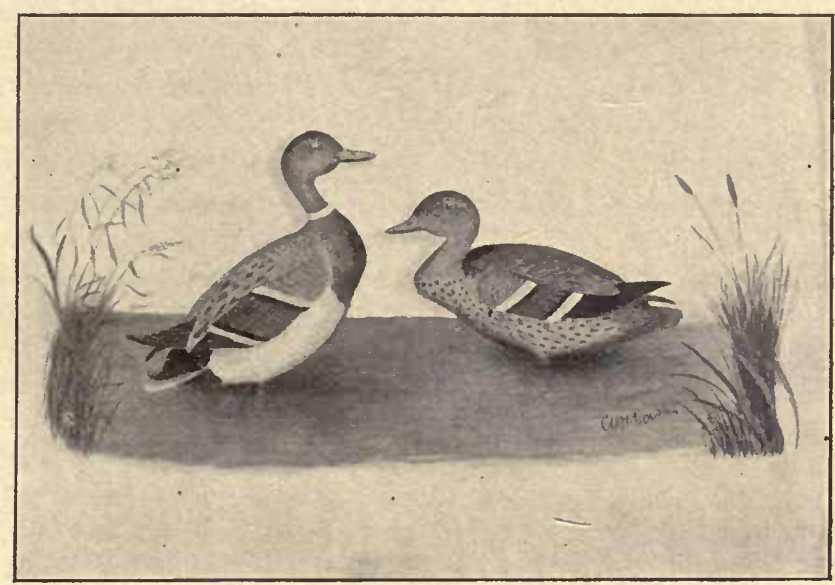

Mallard.

\section{(132) Mallard.}

(Anas boschas.)

Common summer resident of the western part of the Province, less abundant in the east, retires southward as the shallow waters it frequents become frozen over. Breeds throughout its range.

\section{(133) Black Duck.}

(Anas obscura.)

A very common summer resident, breeding in all suitable places throughout the Province. It is more abundant in the east than in th: west, and is only a rare visitor in Manitoba. 


\section{(r33a) Red=legged Black Duck.}

(Anas obscura rubripes.)

Frequently met with in late autumn. Its breeding range is not positively known, but probably includes the Hudson Bay region.

(135) Gadwall.

\section{Genus CHAULELASMUS.}

(Chaulelasmus streperus.)

A very rare summer resident. Breeds commonly in Manitoba and adjoining Provinces westward.

(137) Baldpate.

\section{Genus MARECA.}

\section{(Mareca americana.)}

A fairly common migrant, probably breeds regularly in the interior. 1 have occasionally found it as a summer resident in the marshes of Lakes Erie and Ontario. It breeds commonly in the Western Provinces. Arrives in April and leaves with the first sharp frost.

\section{GENus NETTION.}

(139) Green=winged Teal.

(Nettion carolinensis.)

Common in the spring and autumn migrations, breeding in the north from Labrador to the Pacific coast. Arrives as soon as the marshes are open and leaves about the end of October.

\section{Genus QUERQUEDULA.}

( 140$)$ Blue-winged Teal.

(Querquedula discors.)

Common summer resident, breeding in all suitable places throughout the Province. Arrives in April and leaves about the end of September.

(142) Shoveller.

\section{Genus SPATULA.}

\section{(Spatula clypeata.)}

A regular but uncommon summer resident, breeds throughout its range. Very abundant on the prairie sloughs of Manitoba.

\section{(143) Pintail.}

\section{Genus DAFILA.}

\section{(Dafila acuta.)}

A common spring and autumn visitor to southern Ontario, occasionally breeding in the marshes about Lake Erie and probably regu. 
larly breeding in the interior of the Province. It is a common summer resident of Manitoba.

Arrives as soon as the marshes open and leaves when they freeze up.

\section{Genus AIX.}

\section{(144) Wood Duck.}

(Aix sponsa.)

Formerly an abundant summer resident, breeding everywhere throughout the Province; it is still common, but its numbers are fast decreasing.

Arrives as soon as the ice is out of the marshes, departs about the end of September.

\section{Subfamily Fuligulin $Æ$. (The Sea Ducks.)}

\section{Genus AYTHYA.}

\section{( 46 ) Redhead.}

(Aythya americana.)

A common spring and autumn migrant. They breed from the great lakes northward and abundantly in Manitoba and the Prairie Provinces.

The bulk of them retire southward when their haunts are frozen over. In some seasons a considerable number spend the winter on Lake Ontario.

\section{(147) Canvas=back Duck.}

\section{(Aythya vallisneria.)}

A regular, but not generally a common spring and autumn migrant in Ontario. It breeds commonly in the marshes of the North-West Provinces.

(148) American' Scaup Duck. (Blue-bill.)

\section{(Aythya marila.)}

The great majority of these birds are spring and autumn visitors to southern Ontario, but they do not go very far north to breed, and a great many'spend the winter along the shores of Lake Ontario.

(149) Lesser Scaup Duck. (Little Blue-bill.)

(Aythya affinis.)

Like the last, the great bulk of these ducks are transient visitors in spring and autumn, but some breed in all the large marshes throughout the Province, even along our southern boundary where protected. Formerly they bred regularly in the marsh near Hamilton, and also in that near Toronto.

2 в. 
(150) Ring=necked Duck.

(Aythya collaris.)

Less abundant than the last, with which it is generally confused. It probably breeds throughout its range, for I have often seen it here in summer, though I never found its nest. In eastern Manitoba it breeds regularly.

\section{Genus CLANGULA.}

(15I) American Golden=eye. (Whistler.)

(Clangula clangula americana.)

Common winter visitor and probably breeds in the northern part of the Province, as it regularly does so in all the wooded parts of southern Manitoba.

The bulk arrive in southern Ontario about the end of October and remain until the ice breaks up in the spring.

$\left(^{*}\right)(152)$ Barrow's Golden-eye.

(Clangula islandica.)

An occasional visitor in winter.

\section{Genus CHARITONETTA.}

\section{(1 53) Buffle-head.}

(Charitonetta albeola.)

Common spring and autumn visitor throughout the Province, breeding at some points in southern Ontario, and probably doing so regularly in the more northern portions.

They arrive as soon as the ice goes out in spring and remain in the autumn until their haunts are frozen over.

\section{Genus HẠRELDA.}

(154) Long-tailed Duck. (Coween.)

(Harelda hyemalis.)

A very abundant winter resident on the lakes, arriving about the beginning of November and departing at the end of April. Breeds along the Arctic coast.

\section{GENUS HISTRIONICUS.}

\section{( 55$)$ Harlequin Duck.}

(Histrionicus histrionicus.)

A very rare visitor."

2a $\mathrm{B}$ 


\section{(16o) American Eider.}

\section{Genus SOMATERIA.}

(Somateria dresseri.)

An occasional winter visitor. All the specimens of this duck taken here were in immature plumage, so far as I have been able to learn. Breeds on the North Atlantic coast.

\section{(162) King Eider.}

(Somateria spectabilis.)

Occurring more frequently than the last, but still only an occasional winter visitor. Breeds on the North Atlantic coast. Adult specimens of this duck in full plumage have several times been taken on our lakes in late autumn and early spring.

\section{Genus OIDEMIA.}

(163) Black Scoter. (American Scoter.)

(Oidemia americana.)

A regular winter visitor on the great lakes, sometimes moving southward for a short time if the weather is very severe. Breeds in the Arctic regions.

\section{( 165$)$ White=winged Scoter.}

(Oidemia deglandi.)

A common winter resident, frequenting the great lakes. Breeds about the northern lakes from Labrador to British Columbia.

\section{(166) Surf Scoter.}

(Oidemia perspicillata.)

A regular visitor to our lakes in spring and autumn, probably some remain through the winter, though I have never observed it here in the coldest part of the season.

(167) Ruddy Duck.

\section{Genus ERISMATURA.}

(Erismatura jamaicensis.)

Common in spring and autumn. Breeds from our southern boundary northward.

\section{Subfamily ANSERIN E. (The Geese.) \\ Genus CHEN.}

(*) (169a) Greater Snow Goose. (Wavey.)

(Chen hyperborea nivalis.)

A rare visitor to the western part of this Province. Breeds in the barren grounds along the Arctic coast. 
$\left(^{*}\right)$ (169. I) Blue Goose.

(Chen cærulescens.)

An accidental visitor, which has been met with two or three times in this Province.

\section{GeNus ANSER.}

(*) (I 7 I) White-fronted Goose.

(Anser albifrons gambeli.)

Of very rare occurrence. Breeds in extreme North-West.

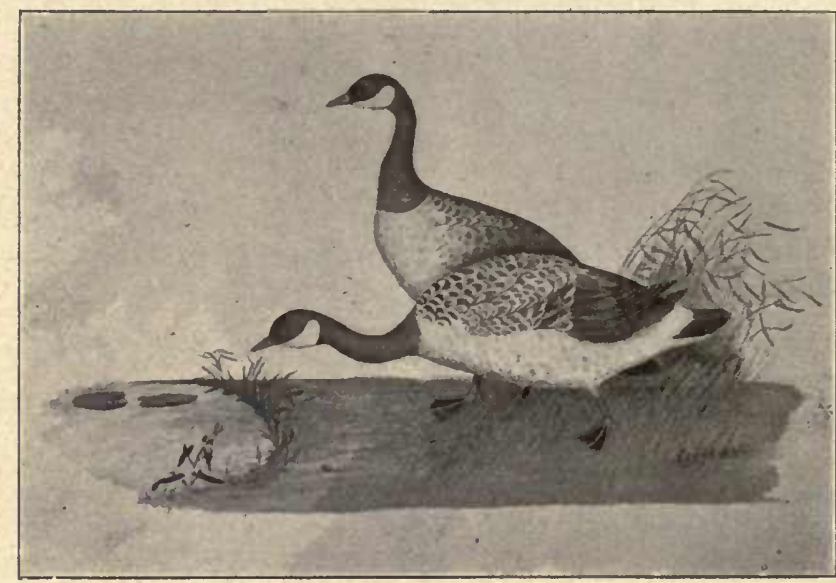

Canada Goose.

Genus BRANTA.

\section{(172) Canada Goose.}

(Branta canadensis.)

A regular spring and autumn visitor to our marshes, but not nearly so abundant now as formerly. Mr. John Maughan informs me that even recently Geese have nested in the preserved marshes of Lake St. Clair and some probably breed in the unfrequented marshes of the northern part of the Province. They breed commonly in the Prairie Provinces.

(*) (r z2a) Hutchin's Goose.

(Branta canadensis hutchinsii.)

An occasional spring and autumn visitor. Breeds chiefly on the shore of the Arctic Sea. 
( 73 ) Brant.

(Branta bernicola.)

A rare visitor. Breeds on the shores of the Arctic Sea.

\section{Subfamily CYGNin E. (The Swans.)}

Genus OLOR.

(*) (180) Whistling Swan.

(Olor columbianus.)

Of somewhat irregular occurrence; generally a few are seen in the spring. Breeds on the shores of the Arctic Sea.

(*) (18I Trumpeter Swan.

(Olor buccinator.)

Like the last, rarely seen now. Breeds on the barren grounds and in the marshes of the far north.

\section{Order HERODIONES. (Herons, Ibises, etc.)}

Wading birds with compressed bodies, long legs and long neck; tibia naked below, feet not.palmate; toes long and slender, cleft or slightly webbed, the hind toe long and usually not elevated, provided with a large claw. Wings broad, rounded, tail short. Head contracted to the stout base of the bill, which is long and usually hard and acute, with sharp cutting edges; nostrils small. They feed upon fish, frogs, mice, and such young birds as may fall in their way.

\section{FAMILY IBIDID $\Subset$.}

Bill very long and slender, compressed, cylindric, curved throughout, the upper mandible with a deep groove reaching nearly or quite to the tip; legs rather long, the toes slightly webbed at base'. Head more or less naked; wings broad; tail short; tarsus scutellate in front.

\section{Genus PLEGADIS.}

(*) (186) Glossy Ibis.

(Plegadis autumnalis.)

An accidental visitor. Mr. McIlwraith records the capture of two near Hamilton in 1857 . I have not heard of any others.

\section{Family ARDEIDÆ. (The Herons, Etc.)}

Bill straight, longer than the head, compressed, acute with sharp cutting edges; upper mandible grooved; nostrils linear; lores naked, the 
bill appearing to run directly to the eyes, rest of head feathered; parts of the body with "powder-down tracts" - strips of short, dusty, or greasy down-like feathers-usually three pairs of these strips, i.e., on the back above the hips, on the belly under the hips and on the breast; usually long plumes from the back of head in the breeding season. Wings broad. Tail very short. Tibiæ largely naked below; toes long and slender, hind toe on a level with the rest, its claw longer than middle claw; middle claw pectinate. Wading birds, feeding on fishes, frogs and any animal small enough for them to swallow.

\section{Subfamily BOtaURinæ. (Bitterns.)}

\section{Genus BOTAURUS.}

(19o) American Bittern.

(Botaurus lentiginosus.)

A common summer resident, breeding throughout its range in the Province. October.

Arrives about the middle of April, departs about the middle of

\section{Genus ARDETTA.}

(19I) Least Bittern.

(Ardetta exilis.)

An abundant summer resident of the larger marshes of southern Ontario, breeding throughout its range.

Arrives about the middle of May and leaves early in September.

\section{(191. I) Cory's Least Bittern.}

(Ardetta neoxena.)

This species seems now to be a regular though very rare summer visitor to the marsh near Toronto. During the last few yeas over a dozen specimens have been taken there. I have not heard of its capture in any other part of the Province.

\section{Subfamily ARDEIN $Æ . \quad$ (Herons.)}

\section{Genus ARDEA.}

\section{(194) Great Blue Heron.}

(Ardea herodias.)

A common summer resident, breeding in communities in the interior of the Province.

Arrives early in April, departs about the middle of September. 


\section{Genus HERODIAS.}

(*) (196) American Egret.

(Herodias egretta.)

A wanderer from the south. About half a dozen specimens have been taken at various points in the Province.

Genus EGRETTA.

(*) (197) Snowy Heron.

(Egretta candidissima.)

An accidental visitor to our southern border.

\section{GeNus BUTORIDES.}

(20I) Green Heron.

(Butorides virescens.)

A regular though never a common summer resident of Ontario. It appears to be generally distributed, but is more frequently found breeding in the swamps near Lake Erie than elsewhere.

\section{Genus NYCTICORAX.}

\section{(202) Black-crowned Night Heron.}

(Nycticorax nycticorax nævius.)

A regular and in places a common summer resident. They breed in the interior of the Province in communities.

As they are quite nocturnal in their habits, they are not often observed even where they are common.

\section{GeNuS NYCTANASSA.}

\section{(203) Yellow=crowned Night Heron.}

(Nyctanassa violacea.)

One taken at Toronto by Mr. John Maughan.

\section{Order PALUDICOLA. (Cranes, Rails, etc.)}

Wading birds. The head rather compressed than globose. Bill hard and not sensitive, not adapted for probing in the mud. The hind toe little elevated. Omnivorous feeders.

\section{Family GRUid $Æ . \quad$ (The Cranes.)}

Very large birds, with the legs and neck extremely long. Wings large, rather short. Tail short. Head more or less naked, with scatter id hairlike feathers. Plumage compact without downy tracts. Bill as long ir 
longer than head, straight and slender; tibia extensively naked; tarsus scutellate; toes rather short, hind toe highly elevated.

(*) (204) Whooping Crane.

Genus GRUS.

(Grus americana.)

A bird of the West which has once straggled into this Province. Mr. McIlwraith records the capture of a specimen in the County of Addington in September, 1871.

\section{(206) Sandhill Crane.}

(Grus mexicana.)

An accidental visitor from the western prairies, which has been met with five or six times, in our Province. It is probable that some, if not all, of the specimens taken here should be referred to G. canadensis.

\section{Family RALlid}

Birds of medium or small size, with compressed bodies and large muscular legs. Wings short, rounded and concave; tail very short. Hind toe rather short, a little elevated; front toes very long. Bill not sensitive at tip. All the species skulk in swamps and marshes, usually keeping well under cover. They feed upon insects and such seeds as are produced in their haunts.

\section{Subfamily RALlinæ. (The Ralls.)}

\section{Genus RALLUS.}

(208) King Rail.

(Rallus elegans.)

A regular summer resident of the marshes of the western end of Lake Erie. I have not heard of its occurrence elsewhere.

(212) Virginia Rail.

(Rallus virginianus.)

An abundant summer resident of the marshes of Ontario, breeding throughout its range.

Arrives about the middle of April and leaves early in October.

\section{Genus PORZANA.}

(214) Carolina Rail.

(Porzana carolina.)

Very abundant summer resident of the marshes all over the Province, breeding throughout its range.

Arrives about the middle of April, departs about the end of October. 


\section{(2 I 5) Yellow Rail.}

(Porzana noveboracensis.)

A regular, but not a common, summer resident of our marshes. I have found it in all large marshes from the St. Clair River, east to. Toronto.

(*) (2 I6) Black Rail.

(Porzana jamaicensis.)

Very rare, probably a summer resident where it occurs. Dr. Cottle of Woodstock recorded the capture of a specimen at Ingersoll in $185^{6}$. In August, 1874, I took four at the upper end of the Dundas marsh and saw others. These birds are very secretive and it requires good dogs to flush them from the rank vegetation in which they skulk.

\section{Subfamily Gallinulin $Æ$. (Gallinules.)}

GENus IONORNIS.

(2 I8) Purple Gallinule.

(Ionornis martinica.)

Of accidental occurrence here. One was taken in the marsh on the Rouge River east of Toronto in 1892.

\section{(2 I9) Florida Gallinule.}

\section{Genus GALLINULA.}

\section{(Gallinule galeata.)}

A common summer resident of the marshes of southern Ontario, breeding throughout its range. tober.

Arrives about the middle of April, departs towards the end of Oc-

\section{Subfamily FUliCin $Æ . \quad$ (The Coots.)}

\section{Genus FULICA.}

\section{(22 I) American coot.}

\section{(Fulica americana.)}

Common summer resident; breeding sparingly in our southern marshes and more abundantly northward.

\section{Order LIMICOLAE. (The Shore Birds.)}

Tibia more or less naked below, legs long, hind toe free and elevated, sometimes wanting. Head globose, abruptly sloping to the base of the bill; completely feathered (except in the case of Pavoncella); gape short; bill weak, flexible, more or less soft skinned and sensitive at tip in most cases, adapted for probing in the mud; nostrils slit-like, surrounded by soft skin. 
The Limicolæ are all birds of small or medium size, frequenting sandy shores and the mud flats of marshes; the Woodcock alone being found in the woods.

\section{FAMILY PHALAROPODIDA.}

Small sandpiper-like birds, with the toes lobed, as in the Coots and Grebes, but the lobes narrower. Body depressed, the lower plumage thick as in the ducks, and capable of resisting water; wings long, tail short; tarsus much compressed.

\section{GENUS CRYMOPHILUS.}

(222) Red Phalarope.

(Crymophilus fulicarius.)

An irregular spring and autumn visitor of rare occurrence.

\section{GENUS PHALAROPUS.}

(223) Northern Phalarope.

(Phalaropus lobatus.)

An irregular spring and autumn visitor of rare occurrence.

\section{Genus STEGANOPUS.}

(224) Wilson's Phalarope.

(Steganopus tricolor.)

An irregular spring and autumn visitor,but rather more frequently met with than either of the preceding Phalaropes.

\section{FAMILY RECURVIROSTRID A.}

Birds with excessively long legs and the bill very slender, long, acute, and in our species curved upward.

\section{Genus RECURVIROSTRA.}

$\left({ }^{*}\right)(225)$ Avocet.

(Recurvirostra americana.)

An accidental visitor from the prairies of the North-West, where it is common.

\section{Family SCOLOPACIDA. (SNipes, Sandpipers, ETc.)}

Bill elongated, usually longer than head, if short not Plover-like, being soft-skinned throughout; nasal grooves in the form of narrow 
channels, ranging from half to nearly the whole length of the bill; sides of lower mandible usually also grooved; nostrils narrow exposed slits; head feathered. Wings usually thin and pointed; tail short and soft. Tibia rarely entirely feathered; hind toe present (except in Calidris); front toes cleft or slightly webbed. Birds of small or medium size. Sexes alike or female slightly larger. Seasonal changes in plumage often strongly marked. Eggs usually four, placed with the small ends together in a slight nest or depression in the ground.

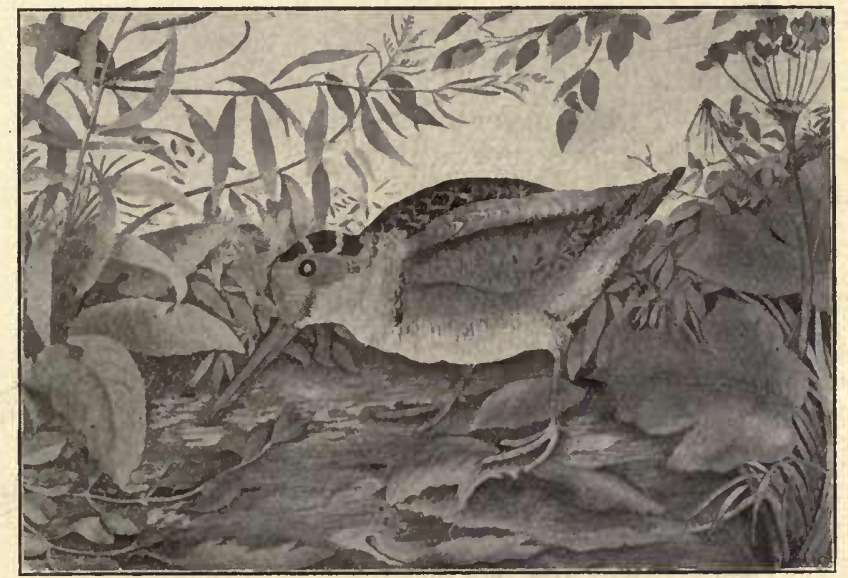

Woodcock.

Genus PHilOHELA.

(228) Woodcock. (American Woodcock.)

(Philohela minor.)

Formerly an abundant summer resident of our swampy woods, but now becoming scarce. Breeds throughout its range.

Arrives about the end of March and departs in November, usually remaining until the first severe frost.

\section{Genus GALLINAGO.}

\section{(23o) Wilson's Snipe.}

(Gallinago delicata.)

Abundant in spring and autumn, the majority going north to breed. Some, however, raise their young in all the larger marshes throughout the Province, from our southern border northward.

The first arrivals in spring generally appear before the end of March and in the autumn the last stragglers remain until the marshes freeze up. 


\section{GENUS MACRORHAMPHUS.}

(231) Dowitcher.

(Macrorhamphus griseus.)

Formerly this bird was not uncommon on the shore of Lake Ontario. during the migrations, but now it is a rather rare spring and autumn visitor.

\section{Genus MICROPALAMA.}

(*) (233) Stilt Sandpiper.

(Micropalama himantopus.)

A rare visitor. I have never met with this species in its spring migration northward, but have several times taken it, on its return in July and August.

(234) Knot.

\section{Genus TRINGA.}

\section{(Tringa canutus.)}

In the neighbourhood of Toronto and Hamilton I have found this. species abundant from the twenty-fifth of May to the end of the first week in June. In the autumn it is seldom seen. Two or three times I have taken specimens in immature plumage in August, but that is all. Breeds in the Arctic regions.

\section{Genus ARQUATELLA.}

\section{(235) Purple Sandpiper.}

(Arquatella maritima.)

A very rare visitor from the northern sea coast, usually occurring late in autumn. Breeds on the shores of the Arctic Ocean.

\section{Genus ACTODROMAS.}

\section{(239) Pectoral Sandpiper.}

(Actodromas maculata.)

A common visitor to our marshes and sandbars. Not observed by me in the spring.

Arrives in July and departs about the end of October.

\section{(240) White=rumped Sandpiper.}

(Actodromas fuscicollis.)

Rather an uncommon species. Possibly breeding, as I have found them here, from the middle of June to the middle of October. 
(24I) Baird's Sandpiper.

(Actodromas bairdii.)

A regular and not uncommon visitor in the neighbourhood of Toronto and at Dundas. Not seen in spring.

Arrives in July, departs early in October.

(242) Least Sandpiper. (Stint.)

(Actodromas minutilla.)

Common spring and autumn visitor, arriving about the twentieth of May, departing early in September.

The bulk of these birds go north to breed, but I think some nest throughout their range in this Province, for some few pairs are always to be found on our sandy beaches all through the summer.

\section{Genus PELIDNA.}

(243a) Red-backed Sandpiper. (Black-heart Plover.)

(Pelidna alpina sakhalina.)

A very abundant visitor in the spring, arriving about the twentieth of May and departing northward about the end of the first week in June.

In the autumn they are much less abundant, the bulk of them going south by another route. The first arrive early in October and by the end of the first week in November the last has gone.

\section{GENUS EREUNETES.}

(246) Semi=palmated Sandpiper. (Stint.)

(Ereunetes pusillus.)

Very abundant from about the twentieth of May to the end of the first week in June and from the middle of July until the end of the first week in September.

The bulk of them go further north to breed, but I have always found some pairs here during the summer.

\section{Genus CALIDRIS.}

\section{(248) Sanderling.}

(Calidris arenaria.)

Very abundant in spring and autumn along the lake shores. Arrive about the tenth of May, depart in October. They spend the summer on their breeding grounds in the far north. 


\section{GeNus LIMOSA.}

(*) (249) Marbled Godwit.

(Limosa fedoa.)

A very rare visitor. Breeds in the North-West.

(*) (25I) Hudsonian Godwit.

(Limosa hæmastica.)

Rather more frequently seen than the last. Breeds on the barren grounds.

\section{Genus TOTANUS.}

(254) Greater Yellow-legs.

(Totanus melanoleucus.)

Common in spring from early in April, until the first week in May.

In the autumn sometimes abundant; arriving towards the end of July and remaining until the end of October.

Breeds in the far north.

\section{(255) Yellow-legs.}

(Totanus flavipes.)

Not common in spring; abundant in autumn. Its movements in the spring correspond with those of the last species.

In the autumn migration, it arrives early in July and leaves before the middle of September. Breeds in the barren grounds.

\section{GENUS HELODROMAS.}

\section{(256) Solitary Sandpiper.}

(Helodromas solitarius.) ant.

Generally distributed throughout the Province, but nowhere abund-

In their spring migration these birds do not seem to visit southern Ontario, for only once have I seen it at that season, viz., May 6th, 1900. In July, after breeding, it may be found along the margins of our streams or upon muddy flats in the marshes. It departs about the end of September.

Dr. C. K. Clarke, of Kingston, has reported finding a nest of this Sandpiper near that town, and no doubt it breeds in the interior of the Province, as it is said to be a regular summer resident of Muskoka and Parry Sound.

(258) Willet.

\section{Genus SYMPHEMIA.}

(Symphemia semipalmata.)

A rare visitor. Breeds in the North-West. 
$\left(*^{*}\right)$ (26o) Ruff.

\section{Genus PAVONCELLA.}

(Pavoncella pugnax.)

A specimen of this European bird in some way wandered to Toronto and was taken there in $\mathbf{1 8 8 2}$. There are a few other records of its occurrence in America, but it can only be regarded as a straggler on this continent.

\section{'Genus BARTRAMIA.}

(26I) Bartramian Sandpiper. (Upland Plover.)

(Bartramia longicauda.)

This is a bird of the prairie and is of rare and local occurrence here. I have found it breeding in the Counties of Brant and Norfolk, and Dr. C. K. Clarke reports it as regularly nesting near Kingston.

\section{GENUS TRYNGITES.}

(262) Buff=breasted Sandpiper.

(Tryngites subruficollis.)

A rather rare and irregular visitor to Ontario during the autumn migration. I have usually found it in August.

Mr. McIlwraith, on the authority of Dr. Macallum, records the discovery of a nest and eggs of this species near Dunnville.

\section{Genus ACTITIS.}

\section{(263) Spotted Sandpiper.}

(Actitis macularia.)

An abundant summer resident, breeding throughout the Province. fember.

Arrives about the first of May, departs about the middle of Sep-

\section{GeNus NUMENIUS.}

(*) (264) Long-billed Curlew.

(Numenius longirostris.)

A very rare visitor, usually in the spring. Breeds in Assiniboia, Alberta and westward.

\section{(265) nudsonian Curlew.}

(Numenius hudsonicus.)

An irregular visitor, sometimes occurring in large numbers in spring; in the autumn it is rarely seen. Breeds on the barren grounds west of Hudson's Bay. 


\section{$\left({ }^{*}\right)(266)$ Eskimo Curlew.}

(Numenius borealis.)

A very rare visitor. Breeds on the barren grounds.

\section{Family CHARADRIID $\mathrm{E}$. (The Plovers.)}

Head rather large, nearly globose; bill of moderate length, shaped somewhat like a pigeon's bill, with a constriction behind the horny terminal portion; nasal fossæ lined with soft skin, through which the slit-like nostrils open. Wings long and pointed, usually reaching beyond the tip of the short tail. Toes, three in all our species (except Squatarola, in which the hind toe is present, but very small); tarsus reticulate; tibia naked below. Sexes similar, but seasonal changes of plumage great. Birds of this family frequent the open fields, sandy shores, or mud flats.

\section{Genus SQUATAROLA.}

\section{(270) Black-bellied Plover.}

(Squatarola squatarola.)

Common spring and autumn visitor, passing through in the spring migration between the twentieth of May and the end of the first week in June. They return from the north in August and remain until about the middle of October. Breeds in the Arctic regions.

\section{GeNuS CHARADRIUS.}

(27I) Golden Plover. (American Golden Plover.)

(Charadrius dominicus.)

I have never found the Golden Plover in Ontario in the spring. Dr. C. K. Clarke informs me that it sometimes occurs near Kingston at that season.

In the autumn it is generally fairly abundant in most parts of the country, visiting the newly ploughed fields, the muddy flats of marshes and the sand bars of the lakes.

It arrives from the north towards the end of August and departs about the middle of October. Breeds on the barren grounds west of Hudson's Bay.

(273) Killdeer.

\section{Genus OXYECHUS.}

(Oxyechus, vociferus.)

A common summer resident, generally distributed over the Province, breeding throughout its range.

Arrives about the end of March, departs early in Octoher. 


\section{Genus ÆGIALITIS.}

(274) Semipalmated Plover. (Ring Plover.)

(Agialitis semipalmata.)

Common in spring from about the middle of May to the end of the first week in June, when it goes north to breed. In July they return and are again abundant until the end of September, sometimes remaining even later. It has occasionally been found nesting in this Province.

\section{(277) Piping Plover.}

Ágialitis meloda.)

A regular but not a common summer resident.

They arrive early in May and probably leave as soon as the young can fly, for I have never found them in the autumn.

A somewhat doubtful variety of this species, A. m. circumcincta, has been taken in Toronto occasionally.

$\left.{ }^{*}\right)(278)$ Snowy Plover.

(Egialitis nivosa.)

Only two specimens have been taken in the Province to my knowledge. One mentioned by Mr. McIlwraith and the other now in the possession of Mr. J. H. Ames, of Toronto.

\section{Family APHRIZID $\AA . \quad$ (The Turnstones.)}

Toes four, not webbed, the hinder short, well developed; tarsus scutellate in front; legs rather long; wings long and pointed; tail. short; bill rather short.

\section{GENUS ARENARIA.}

(283) Turnstone. (Redshank.)

(Arenaria interpres.)

Very abundant at some points along the lake shores in spring; particularly so in some seasons on the sandbar near Toronto and on Burlington Beach near Hamilton.

Arrives about the twenty-fifth of May and remains until the middle of June. In the autumn they are never common. A few in immature plumage return this way about the first of August and remain until the middle of September. Breeds on the Arctic coast from Hudson's Bay westward.

\section{Order GALLIN E. (The Gallinaceous Birds.)}

Bill short, stout, convex, horny, not constricted, nostrils scaled or feathered; cutting edge of upper mandible overlapping the lower. Head often partly or wholly naked, sometimes with fleshy processes. Legs :3 $\mathrm{B}$ 
stout, hind toe elevated, smaller than the other toes. Tarsus broadly scutellate, sometimes feathered, occasionally spurred in the males; claws blunt, not much curved. Wings short, strong, concave. Terrestrial in habit.

A large order, including the chief game birds of the world, as well as most kinds of domesticated poultry.

\section{Family Tetraonid E. (Grouse, Partridges, etc.)}

Hind toe small, short; tarsus without spurs; head nearly or quite feathered.

Subfamily PERdicina:. (Partridges.)

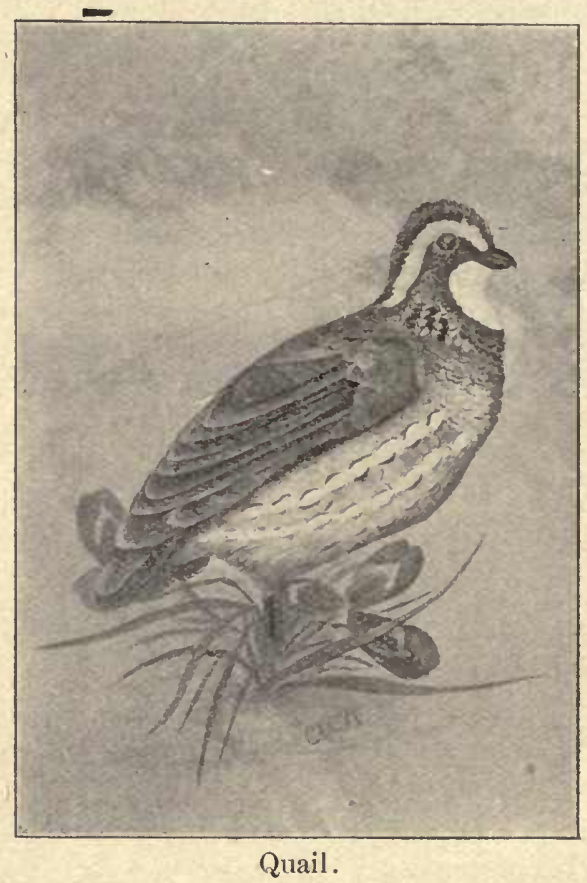

GENUS COLINUS.

(289) Quail. (Bob White.)

(Colinus virginianus.)

A common resident in the south-western counties of Ontario, sometimes ranging east to the County of Ontario. A valuable game bird and one of the farmer's best friends.

3a B. 
Few birds are of greater utility than this. Its whole life is spent among the crops we cultivate, and its food consists during the summer months almost entirely of the insects which are injurious to plants. During the winter it consumes great quantities of weed seeds, a large portion of which are gathered from fence corners and other neglected parts of the farm lands. It is from these places that the cultivated fields are regularly seeded down with weeds every season, and the Quail is an important factor in keeping them in check.

\section{Subfamily Tetraonin E. (The Grouse.)}

\section{Genus CAN aCHITES.}

(298) Canada Grouse. (Spruce Partridge.)

(Canachites canadensis.)

Common resident in the northern districts. It formerly ranged much further south than it does at present, but its tameness has led to its extermination in the settled parts of the country.

\section{Genus BONASA.}

(300) Ruffed Grouse. (Partridge.)

(Bonasa umbellus.)

A common resident in woodlands throughout the Province.

Three sub-species have been separated from the typical form, all of which are found here with endless intermediate variations.

\section{Genus LAGOPUS.}

(30 I) Willow Ptarmigan.

(Lagopus lagopus.)

A regular winter visitor to the northern parts of the Province, sometimes coming as far south as Sault Ste. Marie, Lake Superior.

Mr. J. H. Ames, of Toronto, has one, which was taken near Whitby on Lake Ontario.

\section{Genus TYMPANUCHUS.}

(30.5) Pinnated Grouse. (Prairie Hen, Prairie Chicken.)

(Tympanuchus americanus.)

Formerly a resident of the open country along our south-western border, but now extinct there.

\section{Genus PEDICCETES.}

(308) Sharp-tailed Grouse. (Prairie Chicken.)

(Pediœcetes phasianellus.)

A scarce resident of the north-western part of the Province. During the last few years several of these birds have strayed into Parry Sound 
and Muskoka. It is possible that as these districts are cleared and become more prairie like, the Sharp-tail may find them adapted to its requirements and become more abundant there.

Family Phasianid $£$. (The Pheasants, Turkeys, etc.)

The chief family of the Gallinæ, differing as a whole from the Tetraonidæ in having the tarsus in the male armed with a spur. In many species the head is naked, in others the tail is long and vaulted or otherwise peculiar.

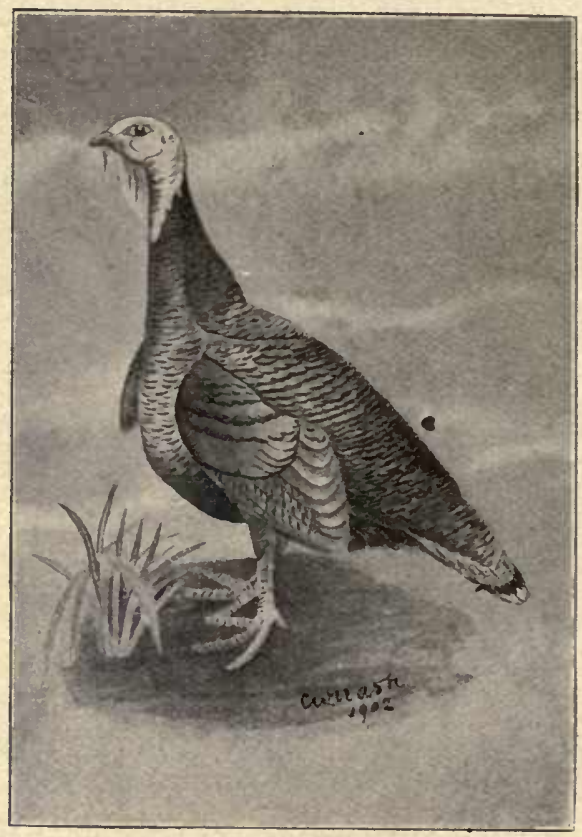

Wild Turkey.

Subfamily MELEAGRIN E.

\section{GeNus MELEAGRIS.}

(*) (3roa) Wild Turkey.

(Meleagris gallopavo silvestris.)

Formerly common in all the south-western counties, ranging east into Wentworth. There may still be a few left in that district, but I have not heard of any for several years.

Resıuent wherever found. 


\section{Order COLUMBA. (The Pigeons.)}

Bill straight, compressed, the horny tip separated by a constriction from the soft part. Nostrils opening beneath a soft, humid membrane or cere, at base of bill. Frontal feathers sweeping in a strongly convex outline across base of upper mandible. Hind toe on a level with the others. Tail in our species long, wedge shaped, the feathers pointed.

\section{Family COlumbid $\approx$. (Pigeons.)} serted.

Wings long, pointed; plumage compact, the feathers loosely in-

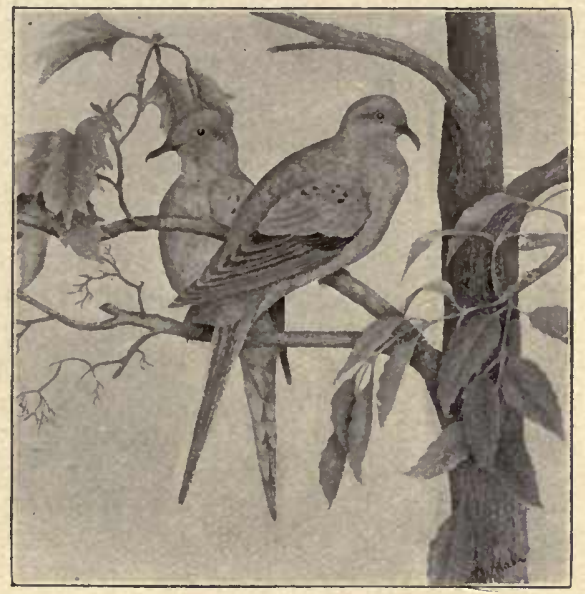

Passenger Pigeon.

\section{Genus ECTOPISTES.}

\section{(3I5) Passenger Pigeon.}

(Ectopistes migratorius.)

Formerly a very abundant summer resident, occurring in flocks of countless thousands, but now very scarce.

Dr. C. K. Clarke informs me that he found a small colony breeding in eastern Ontario in 1898.

\section{Genus ZENAIDURA.}

\section{(3i6) Mourning Dove.}

(Zenaidura macroura.)

A common summer resident, but somewhat locally distributed. Breeding throughout its range. 
The great majority of these birds are migrants, arriving here in April and leaving in October, but during the last few years small flocks have been seen in several localities, all through the winter.

\section{Order RAPTORES. (The Birds of Prey.)}

Carnivorous birds, often of large size and great strength. Bill strong, cered at base, hooked at the end. Claws very strong, except in the Vultures. Tibia, and often the tarsus, feathered. Hind toe developed, elevated or not.

Some of them feed upon carrion, others upon reptiles or fishes, but the most of them upon small mammals, birds and insects.

This order includes a large number of very useful birds, while a few of them may be considered injurious by reason of their raids upon domestic fowls.

\section{Family CATHARTidÆ. (American Vultures.)}

Head and part of neck bare Eyes lateral; ears small. Bill lengthened, comparatively weak and but little hooked; nostrils perforate. Wings very long and strong, giving a strength and grace of flight which is not excelled by any other birds. Hind toe short and elevated; front toes long, somewhat webped, with rather weak and straightish claws. Large, slovenly looking birds, without the strength and spirit of the Hawks and Owls. They are voracious consumers of carrion and animal refuse of all kinds, and hence are valued as scavengers in the warm countries where they most abound.

\section{GeNus CATHARTES.}

\section{(*) (325) Turkey Vulture.}

(Cathartes aura.)

A great wanderer, which is of occasional occurrence in Ontario, specimens having been taken at various places from the eastern boundary to the west, where it was formerly not uncommon.

\section{Family FALCONID Æ. (Falcons, Hawks, Eagles, etc.)}

Head fully feathered; no ear tufts. Eyes lateral; eyelids provided with lashes; usually a projecting bony eyebrow; no complete facial disk. Toes always naked; tarsus naked also except in Aquila and Archibuteo. Hind toe not elevated. Bill stout, strongly hooked, its base not hidden by feathers. Claws very strong and sharp, the hind claw not shorter than the others. 
Subfamly ACCipltrin E. (Kites, Hawks, Eagles, etc.)

\section{Genus ELANOIDES.}

\section{(327) Swallow-tailed Kite.}

(Elanoides forficatus.)

Mr. Mcllwraith records the occurrence of this species in western Ontario and also at Ottawa, and it is quite likely to be seen here again, as if is a great wanderer.

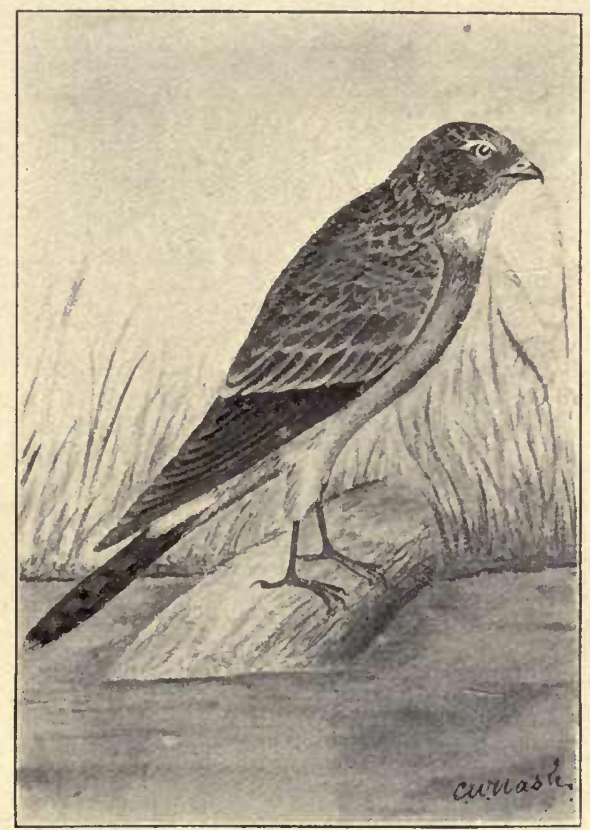

Marsh Hawk.

\section{(33I) Marsh Hawk.}

Genus CIRCUS.

\section{(Circus hudsonius.)}

Very common summer resident, breeding in secluded marshy places throughout the Province. Arrives early in April, departs about the end of October. One of our most useful Hawks, feeding principally upon the destructive meadow mouse. This Hawk may readily be distinguished from all others by its low skimming flight, as it works over the meadows in search of its favorite food, and also by the white patch at the base of its tail, which is very conspicuous. A heavy penalty should be inflicted on persons who destroy these birds. 


\section{Genus ACCIPITER.}

\section{(332) Sharp-shinned Hawk.}

(Accipiter velox.)

Common summer resident, breeding throughout its range. Arrives early in April. The bulk depart about the middle of September, but stragglers often remain until the end of October.

This bird is very destructive to young poultry and the small insectivorous birds.

\section{(333) Cooper's Hawk.}

(Accipiter cooperi.)

A summer resident, but not nearly so abundant as the last. Breeds in the interior of the Province.

A very destructive hawk.

(334) Goshawk.

(Accipiter atricapillus.)

(A winter visitor to southern Ontario. Resident and breeding in the interior.

This hawk is capable of killing fullgrown fowls and does so at every opportunity.

\section{Genus BUTEO.}

\section{(337) Red-tailed Hawk.}

(Buteo borealis.)

A common summer resident, breeding in the interior. Arrives early in March, departs at the beginning of November. A few have been seen in winter.

A dark form of this hawk now given sub-specific rank as the Western Red-tailed Hawk, B. b. calurus, has been occasionally taken in Ontario.

This is one of the most useful species, feeding largely upon meadow mice, grasshoppers, and frogs.

\section{(339) Red=shouldered Hawk.}

(Buteo lineatus.)

Common summer resident. Less frequently seen than the last, or perhaps more local in its distribution. Breeds in the interior. Arrives a little later than the Red-tail and leaves towards the end of October. I have seen specimens in winter, but not often. hoppers.

A very useful hawk, feeding chiefly on mice, reptiles and grass- 
(*) (342) Swainson's Hawk.

(Buteo swainsoni.)

A rare visitor from the western prairies, where it is abundant.

\section{(343) Broad-winged Hawk.}

(Buteo platypterus.)

A common summer resident, breeds throughout its range. A useful species.

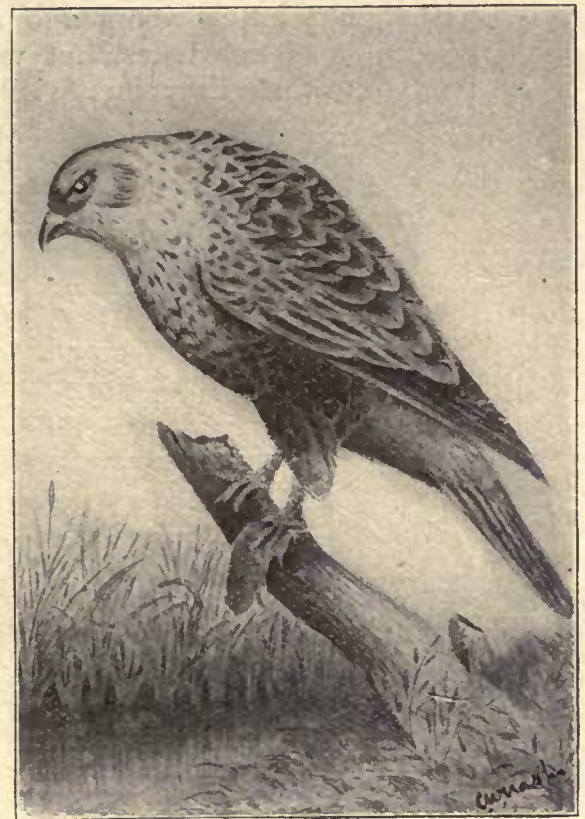

American Rough-legged Hawk.

GENUS ARCHIBUTEO.

\section{(347) American Rough-legged Hawk.}

(Archibuteo lagopus sancti-johannis.)

A common visitor in spring and autumn, probably a summer resident in the northern portion of the Province.

They arrive early in April and the bulk have departed by the end of November.

One of our most beneficial birds, its food consisting almost entirely of mice and grasshoppers.

I have found as many as eight meadow mice in the stomach and crop of one of these birds. 
(*) (349) Golden Eagle.

\section{Genus AQUila.}

(Aquila chrysaëtos.)

An irregular visitor to southern Ontario, probably resident in the unsettled north country.

\section{(352) Bald Eagle.}

\section{GENUS HALIAETUS.}

(Haliæetus leucocephalus alascanus.)

A resident species which until a few years ago regularly bred in certain localities along the shores of our lakes, but which has now retired to the quiet of the interior to raise its young, visiting southern Ontario in winter.

Subfamily Falconin Æ. (Falcons.)

Genus FALCO.

\section{(353) White Gyrfalcon.}

(Falco islandus.)

An accidental visitor.

(354) Gray Gyrfalcon.

(Falco rusticolus.)

As rare as the last.

\section{(356) Duck Hawk.}

(Falco peregrinus anatum.)

A regular, but not a common, autumn visitor to southern Ontario. Rarely seen in spring. Has been found breeding in eastern Ontario and also in Muskoka.

\section{(357) Pigeon Hawk.}

(Falco columbarius.)

Not often seen in the spring, but common in autumn. I have occasionally seen it in winter. The great majority go south about the end of September.

It breeds in the unsettled districts of the interior from Muskoka northward.

\section{(360) Sparrow Hawk.}

(Falco sparverius.)

A common summer resident, breeds throughout its range. Arrives early in April, departs about the end of September.

A very useful bird, feeding on mice and insects chiefly. Two or three times when I have taken these Hawks in early summer, I have found their stomachs filled with cutworms and at the same time noticed that 
their feet were covered with mud. Just how they obtain these underground larvæ I have not been able to ascertain, but it would seem that they either scratch them out or are able in some way to locate the spot at which they are hidden and can then capture them by thrusting their claws into the moist soil.

\section{Genus POLYBORUS.}

(362) Audubon's Caracara.

(Polyborus cheriway.)

Mr. G. E. Atkinson has recorded finding a dead specimen washed up on the north shore of Lake Superior on the 18th of July, 1892.

\section{SubFamily PANDIONINAE. (Ospreys.)}

\section{Genus PANDION.}

(364) American Osprey. (1 ish Hawk.)

(Pandion haliaëtus carolinensis.)

A common summer resident, breeding in suitable places through the Province. Its nesting places now are in the unsettled parts of the interior, where the lakes are still surrounded by trees sufficiently large to meet the bird's requirements.

Arrives in April, departs at the end of September.

\section{Suborder STRIGES. (Owls.)}

Family STRIGIDÆ. (The Barn Owls.)

A small family comprising those owls which have long faces, the facial disk being complete and subtriangular. The middle and inner toes are about equal in length and the middle claw is pectinate below.

\section{Genus STRIX.}

(*) (365) American Barn Owl.

(Strix pratincola.)

A rare visitor from the south. Five or six specimens of this bird have been met with in southern Ontario.

\section{Family BUBONIDA. (The Horned Owls, etc.)}

Head very large, shortened lengthwise, and greatly expanded laterally, the eyes directed forwards and partly surrounded by a more or less complete circular disk of radiating feathers of peculiar texture; loral feathers antrorse, long and dense; feathers on the sides of forehead often elongated into earlike tufts. Plumage very soft and lax, rendering the flight almost noiseless; its colours blended and mottled so as to baffle description. External ear very large, often provided with a movable 
flap. Outer toe reversible; claws very sharp, long, and strong; inner toe shorter than middle; middle claw not pectinate. All our species are nocturnal except Nyctea and Surnia.

\section{Genus ASIO.}

(366) American Long-eared Owl.

(Asio wilsonianus.)

A fairly common summer resident, breeding throughout its range in the Province, wherever there are woods. More frequently seen in the autumn than at any other season.

Feeds almost entirely upon meadow mice and large insects. I have examined a great many of these birds and so far have never found anything else in their stomachs; never even the trace of a feather.

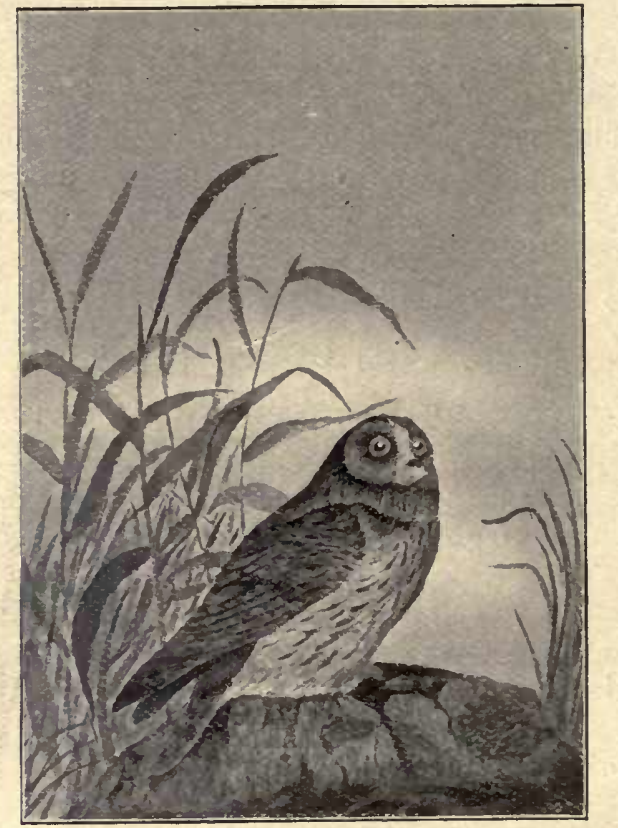

Short-eared Owl.

(367) Short=eared Owl. (Marsh Owl.)

(Asio accipitrinus.)

This Owl is sometimes very common in the autumn, about the low meadows and marshes. In such places I have found them also during the winter at times. Its movements seem to depend altogether upon the food supply. When meadow mice are abundant and available the owls will remain and feed upon them, but if the snow becomes deep so that 
the mice are entirely protected by it, then the owls go south. This bird is peculiarly adapted to act as a check upon the undue increase of field mice. It lives and breeds entirely in the places most frequented by them, and so long as these destructive creatures can be obtained, the Owl will feed upon them; apparently preferring them to any other food. When the supply of mice fails, however, these Owls will feed upon such small birds as may be found in their haunts, and will at times kill more than they can devour.

Dr. C. K. Clarke informs me that it has been found nesting in the marsh near Kingston, and as $I$ have seen it during the summer months in other marshes, no doubt it breeds sparingly in southern Ontario and more abundantly in suitable places in the northern part of the Province.

If these Owls were less persecuted than they are, they would certainly breed here whenever their favourite food was abundant, as they do in Great Britain, and we should then hear less about the damage done to grain and fruit trees by meadow mice.

\section{(368) Barred Owl.}

\section{Genus SYRNIUM.}

(Syrnium varium.)

This bird is generally distrinuted through the Province, as far north as Lake Superior and the Ottawa River, but is not common anywhere; there are certain places at which it appears regularly every autumn, while in other localities it is rarely, if ever, seen. Nests have been found all through its range.

It is not sufficiently abundant to be of importance from an agricultural point of view. Those I have taken here always contained mice, but to the south of us, where the poultry are allowed to roost on trees, it is accused of killing half-grown chickens.

\section{Genus SCOTIAPTEX.}

(370) Great Grey Owl. (Cinereus Owl.)

(Scotiaptex nebulosa.)

An irregular winter visitor, occasionally occurring in considerable numbers and a few are found here nearly every season. Breeds in the Arctic regions.

\section{Genus CRYPTOGLAUX.}

$\left({ }^{*}\right)$ (37 r) Richardson's Owl.

(Cryptoglaux tengmalmi richardsoni.)

A winter visitor from the far north, seldom seen in southern Ontario.

(372) Saw-whet Owl.

(Cryptoglaux acadica.)

Although this little Owl is a resident of Ontario, it is peculiar in its distribution. It is most frequently seen in winter and will in some sea- 
sons be quite common in a locality for a time and may not again be seen there for several years. Like all other birds of prey, it is attracted to places where food is abundant. It breeds sparingly in southern Ontario and probably commonly in the undisturbed woods of the interior.

Its food consists almost entirely of mice; when these are scarce, an occasional insect or small bird is taken.

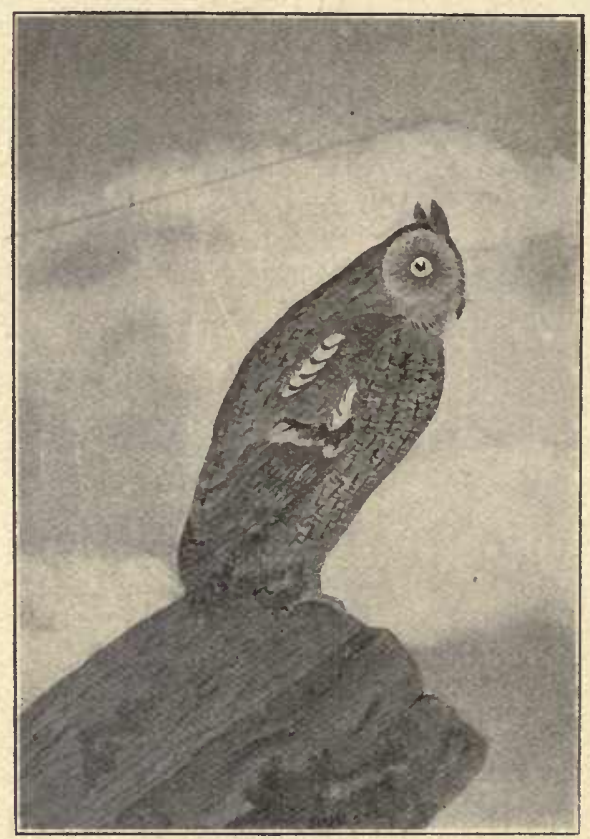

Screech Owl.

\section{(373) Screech Owl.}

\section{Genus MEGASCOPS.}

\section{(Megascops asio.)}

A common resident in southern Ontario, breeding throughout its range.

A particularly useful bird and one which, if left unmolested, will become almost domesticated. It will take up its abode in and about the barns and outbuildings and soon becomes comparatively tame. It is the most indefatigable mouser we have, for not only does it kill mice to supply its immediate wants, but also for the pleasure of hunting them. Besides this, it also does useful work in keeping the common House Sparrow within proper limits. 


\section{(375) Great Horned Owl.}

\section{Genus BUBO.}

(Bubo virginianus.)

A common resident, breeding throughout its range. The strongest and most courageous of our birds of prey. Commonly considered to be injurious to the farmer, because it occasionally kills poultry. No doubt it will do this in winter, when its natural food is difficult to get; but the farmer who leaves his fowls to roost out and unprotected on cold nights cannot find them very profitable and certainly deserves to lose them. As against this, should be set off the value of the bird's services in keeping in check the rats, mice, crows and other injurious creatures; even skunks: often fall victims to the Horned Owl's strength and rapacity.

\section{(376) Snowy Owl.}

\section{GENus NYCTEA.}

\section{(Nyctea nyctea.)}

A winter visitor, occurring in varying numbers almost every season. This is a diurnal species, hunting its prey much after the fashion of the falcons.

Breeds in the Arctic regions.

\section{Genus SURNiA.}

\section{(377) Hawk Owl. (American Hawk Owl.)}

(Surnia ulula caparoch.)

A regular winter visitor in northern Ontario, not often seen in the southern portions of the Province.

It is diurnal, and when hunting adopts much the same methods as our Sparrow Hawk. In northern Manitoba, where it is rather common in winter, I frequently saw it hovering over the snow-covered plains just as our little Hawk does over the fields in summer.

Breeds in the far north.

\section{Order coccYGES. (cuckoos and Kingfishers.)}

This order is not very largely represented in Canada. The families comprised in it have but little in common so far as outward appearance is concerned, but the characteristics of each are well marked.

\section{Suborder CUCUli. (Cuckoos.) \\ Family CUCULid}

Bill gently curved, lengthened, without rectal bristles or nasal tufts. Tongue not extensible. Tarsus long, nearly naked. Toes not webised, cleft to base; two in front, two behind. Tail long in our species.

Arboreal birds of great economic value, feeding almost entirely on insects. They devour great numbers of tent caterpillars and the various hairy larvæ, which are rejected by most birds. 


\section{Subfamily COCCyZin Æ. (American Cuckoos.) \\ Genus COCCYZUS.}

\section{(387) Yellow=billed Cuckoo.}

(Loccyzus americanus.)

A regular, but not a common, summer resident; breeding throughout its range.

\section{(388) Black-billed Cuckoo.}

(Coccyzus erythrophthalmus.)

A common summer resident, breeding throughout its range. tember.

Arrives about the twentieth of May, departs about the end of Sep-

\section{Suborder ALCYONES. (KingFishers.) \\ Family AlCEDinid}

Head large; bill long, straight and strong; gape deep, edges nct serrate. Wings long; tail short. Tarsus very short. Toes three in front, one behind, the outer and middle toes united half their length, with a continuous sole beneath.

We have but one species.

\section{(390) Belted Kingfisher.}

\section{Genus CERYLE.}

(Ceryle alcyon.)

A common summer resident, breeding throughout its range.

Arrives about the beginning of April, departs early in October. I have several times found these birds spending the winter on rapid streams in southern Ontario, and once near Bala in Muskoka.

\section{Order PICI. (Woodpeckers, etc.)}

Feet zygodactyle, i.e., having the toes in pairs - two forward ard two behind (except in Picoides, in which the hind toe is wanting). Tail feathers pointed and with strong shafts; used as a prop to assist the birds in supporting themselves against the trunks of trees.

\section{Family PICIDÆ. (WOODPECKers.)}

Bill stout, usually straight, with the tip distinctly truncate (excespt in Colaptes), adapted for hammering or boring into wood. Tongue long, flattish, barbed, capable of great protrusion, adapted for securing insects (except in Sphyrapicus.) Hyoid process peculiar, the horns generally very long, curving up around the skull behind and over forward again to the ear, or beyond. Claws compressed, sharp and strong.

All are chiefly insectivorous, the majority of them obtaining their food by boring into the trunks of trees and extracting the larvæ which feed upon the cambium. 
These birds are of great economic value to the farmer, fruit-grower and forester, and should be strictly protected by everyone having the slightest interest in trees.

\section{Genus DRYOBATES.}

\section{(393) Hairy Woodpecker.}

(Dryobates villosus.)

A common resident, breeding throughout the Province. The variety D. v. leucomelas, is the form chiefly found in southern Ontario.

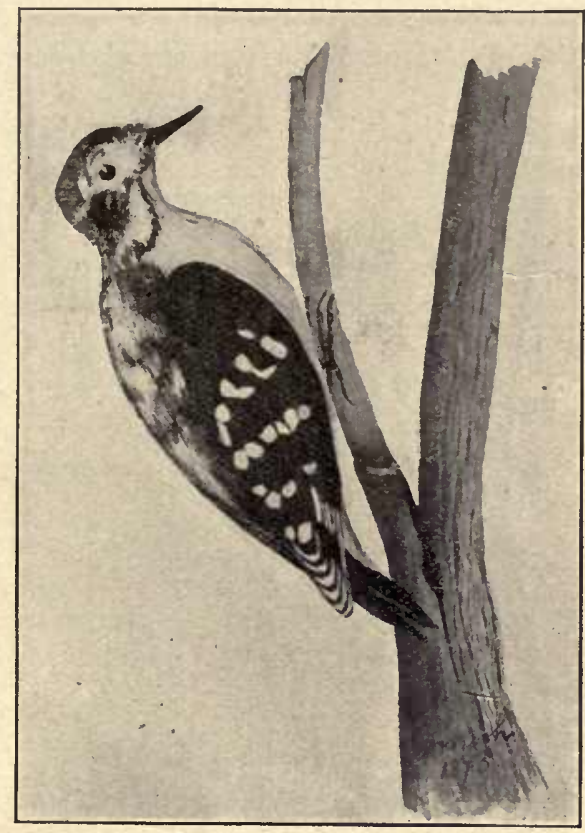

Downy Woodpecker.

\section{(394) Downy Woodpecker.}

(Dryobates pubescens.)

A common resident, breeding throughout the Province. Our form is chiefly D. p. medianus.

\section{Genus PICOIDES.}

(40o) Arctic Three-toed Woodpecker.

(Picoides arcticus.)

Common resident in the northern part of the Province, rare winter visitor in the southern part.

Breeds in the northern part of its range.

4 B. 
(*) (401) American Three=toed Woodpecker.

(Picoides americanus.)

Resident in the northern part of Ontario, but much less abundant than the last. Occasionally wanders into southern Ontario during the winter.

\section{GENus SPHYRAPICUS.}

(402) Yellow-bellied Woodpecker. (Sapsucker.)

(Sphyrapicus varius.)

A common summer resident, breeding throughout its range in the Province.

Arrives about the middle of April, departs about the middle of Sep$\mathrm{t}(\mathrm{m}$ mber.

It is this species only which bores holes in the bark of trees for the purpose of obtaining the sap.

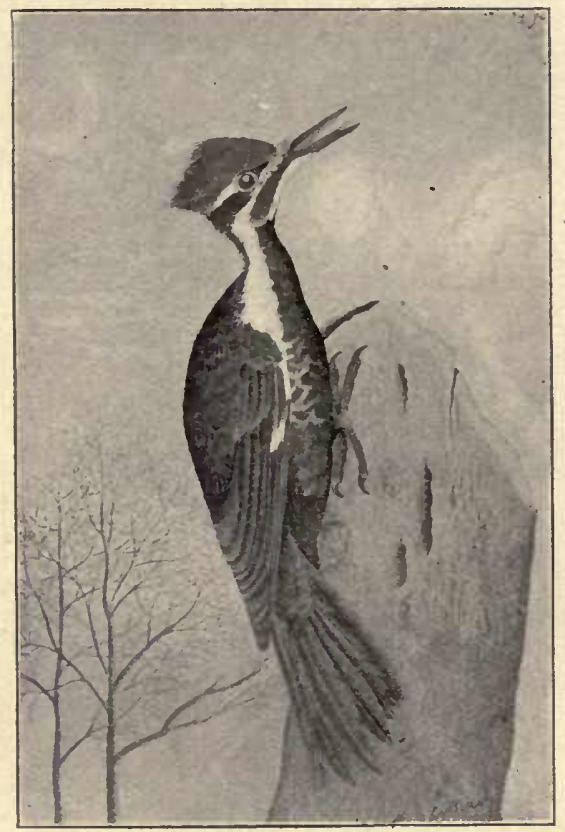

Pileated Wuodpecker.

lienus CEOPHLCEUS.

(405) Pileated Woodpecker. (Cock of the Woods.)

(Ceophlous pileatus.)

Resident, but restricted to that part of the country still covered with heavy timber. Breeds throughout its range in the Province.

Our form is C. p. abieticola.

ta $\mathrm{B}$. 


\section{Genus MELANERPES.}

(406) Red-headed Woodpecker.

(Melanerpes erythrocephalous.)

A summer resident, still commion, but much less abundant than it was a few years ago. Breeds throughout its range.

Arrives early in May, ueparts early in September.

\section{Genus CENTURUS.}

(*) (409) Red-bellied Woodpecker.

(Centurus carolinus.)

Rare summer resident in the south-western counties; occurring regularly as far east as the County of Wentworth. Breeds throughout its range in the Province.

\section{Genus COLAPTES.}

(4I2) Flicker. (Golden-winged Woodpecker, High-holer.) (Colaptes auratus.)

Common summer resident. Breeds throughout the Province.

Arrives about the middle of April, departs early in October.

Our form is C. a. luteus.

Though classed amongst the Woodpeckers, by reason of certain similarities of structure, it does less wood-pecking than any other of its family, its beak not being so well fitted for that operation as the beaks of the others. It is chiefly a ground feeder, ants forming a large portion of its food. For the purpose of enabling it to capture these insects in their underground burrows, its tongue is peculiarly specialized.

\section{Order MACROCHIRES. (Goatsuckers, Swifts and Humming Birds.)}

Wings very long and pointed. ^arsus short; feet small and weak, with three toes in front, one behind. The hind toe usually somewhat elevated.

\section{FAMILY CAPRIMULGID $Æ$.}

Mouth highly specialized, the gape enormously wide, beak short. In Antrostomus the rectal bristles are long and coarse, very distinct. Plumage soft in texture, much marbled and mottled with black, brown, grey and yellowish white, the combination forming a splendid example of protective coloration. The middle claw pectinate. Largely nocturnal. Entirely insectivorous, obtaining their food while on the wing. 


\section{Genus ANTROSTOMUS.}

(4I7) Whip=poor=will.

(Antrostomus vociferus.)

A common resident in the woods. Breeds throughout its range in the Province.

Arrives early in May, departs early in October.

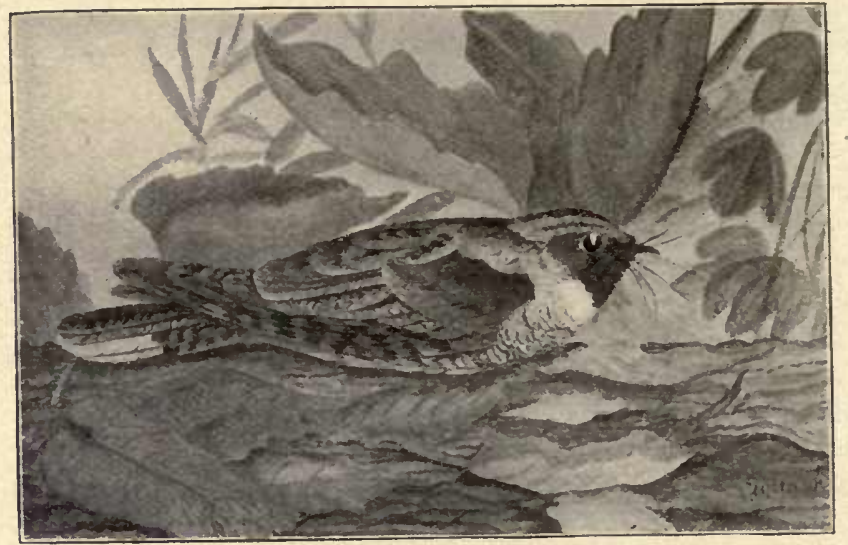

Whip-poor-will.

\section{Genus CHORDEILES.}

(420) Night Hawk.

(Chordeiles virginianus.)

An abundant summer resident. Breeds throughout its range in the Province.

Arrives about the middle of May, departs early in September.

Suborder CYPSELI. (Swifts.)

FAMILY MICROPODIDÆ. (uWIFTS.)

Subfamily ChætuRin $A$. (Spine-tailed Swifts.)

Bill weak and small, gape large, deeply cleft. Wings very long, thin and pointed; secondaries very short. Feet small, weak, toes completely cleft ; middle claw not pectinate; no rectal bristles. In our species tail rounded, its feathers with the shaft spinous, projecting beyond the plumage; the salivary glands are highly developed and their secretion is used as a glue in the construction of the nest. 


\section{GenUS CHATURA.}

(423) Chimney Swift. (Chimney Swallow.)

(Chætura pelagica.)

An awundant summer resident. Breeds throughout its range in the Province. Formerly nested in hollow trees, but has abandoned them and now takes up its residence in chimneys and barns.

Arrives early in May, departs at the end of August or early in September.

Suborder TROCHILI. (Humming Birds.)

Family TROCHILIDÆ. (HUMming BiRds.)

Bill long, pointed, awl-shaped. Tongue capable of great protrusion. Wings long and pointed; secondaries short. Feet very small, with long, sharp claws. Smallest of all our birds. Feeds largely upon small insects and the nectar from flowers. It usually obtains its food while hovering about the blossoms of plants.

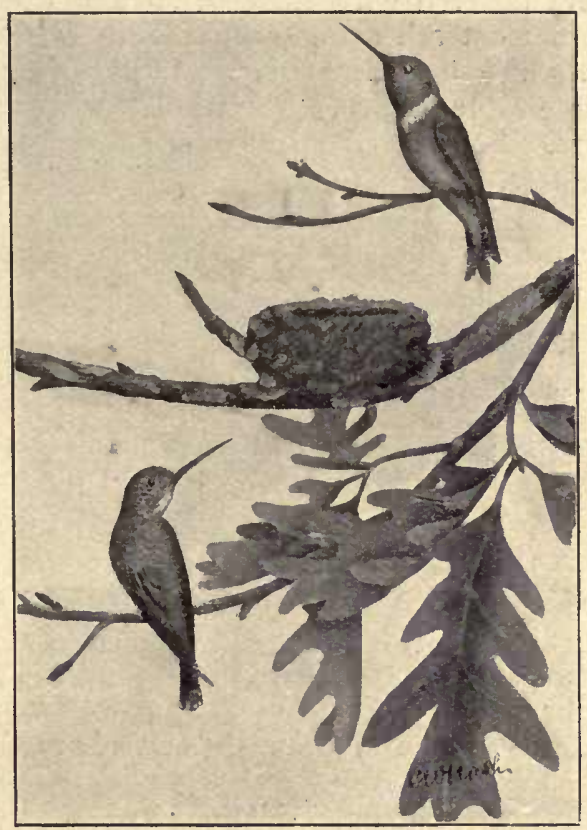

Ruby-throated Humming Bird.

Genus TROCHILUS.

\section{(428) Ruby=throated Humming Bird.}

(Trochilus colubris.)

A common summer resident. Breeds throughout its range in the Province. Arrives about the middre of May, departs about the middle of September. 


\section{Order PASSERES. (Perching Birds.)}

Toes always four; feet fitted for perching; the hind toe always on a level with the rest; its claw at least as long as that of the middle toe; none of the toes versatile and none webbed; wing coverts few, chiefly in two series.

\section{Suborder Clamatores. (Songless Perching Birds.) \\ Family tyrannide. (Tyrant Flycatchers.)}

Bill typically broad, triangular, depressed, abruptly hooked and notched at tip, with long rectal bristles; commissure nearly straight; nostrils small, usually partly concealed. Tarsus with its back and sides as well as the front covered with scutella, so that there is no undivided ridge behind, as in most other Passeres.

All our species are insectivorous, capturing their food by darting upon it from some elevated perch. The whole family are decidedly beneficial to agriculture. Some of them have very pleasant notes, but none of them are songsters.

\section{GENUS TYRANNUS.}

(444) Kingbird.

(Tyrannus tyrannus.)

An abundant summer resident; breeds throughout its range in the Province.

Arrives about the tenth of May, departs about the end of August.

\section{Genus MYIARCHUS.}

\section{(452) Crested Flycatcher.}

(Myiarchus crinitus.)

Common summer resident, breeding in woods and orchards throughout its range in the Province.

Arrives about the middle of May, departs about the end of August.

\section{GENUS SAYORNIS.}

(456) Phœbe.

(Sayornis phœbe.)

An abundant summer resident, breeding about farm buildings and bridges throughout its range in the Province.

Arrives early in April, departs early in October.

A most useful bird and one that will return year after year to its nesting place on the farm, if not molested. 


\section{Genus NUTTALLORNIS.}

(459) Olive=sided Flycatcher.

(Nuttallornis borealis.)

A regular but uncommon visitor to southern Ontario. I have found one or two each spring for several years, but have not seen it at any other season. It is said to be common and breed in the Muskoka and Parry Sound Districts.

\section{Genus CONTOPUS.}

(46i) Wood Pewee.

(Contopus virens.)

Common summer resident, breeding in woods throughout its range in the Province. tember.

Arrives about the middle of May, departs about the middle of Sep-

\section{GENUS EMPIDONAX.}

(463) Yellow-bellied Flycatcher.

(Empidonax flaviventris.)

A rather uncommon visitor. I have seen a few each spring, but never later than June.

It breeds regularly in the wooded parts of the interior.

(466) Traill's Flycatcher.

(Empidonax trailli.)

The eastern form, E. t. alnorum, is a regular visitor, generally distributed, but never common. It frequents low grounds where alders and willows flourish. Breeds in the interior.

(467) Least Flycatcher.

(Empidonax minimus.

Common summer resident, breeding in orchards, shrubberies and woodlands throughout its range in the Province.

Arrives about the middle of May, departs at the end of August.

\section{Suborder OSCINES. (Song Birds.) \\ Family alaUdid e. (The Larks.)}

Tarsus obtuse and scutellate behind as well as in front. Bill short: nostrils concealed by tufts of antrorse feathers; hind claw very long and nearly straight; inner secondaries lengthened and flowing. Our species have a little tuft of lengthened black feathers over each ear and the tail not forked. 


\section{Genus OTOCORIS.}

(*) (474) Horned Lark. (Shore Lark.)

(Otocoris alpestris.)

This form of the Shore Lark is a winter visitor and is rarely seen now.

Twenty-five years ago it was common here in severe weather, frequently with the Snow Buntings. I have never found it breeding in the Province. Its summer home is in the far north.

\section{(474b) Prairie Horned Lark.}

(Otocoris alpestris praticola.)

This sub-species is now a common summer resident, breeding in open fields wherever it occurs in the Province.

It appears to have extended its range from the prairies as the timber has been cleared off and the land brought under cultivation.

Arrives about the tenth of February, departs late in November. In the south-western counties it is resident, large numbers remaining there all through the winter.

\section{Family CORVIDE. (The Crows and Jays.)}

Bill long and strong, usually notched, its commissure not angulated; nostrils usually concealed by tufts of bristly feathers, which are branched to their tips. Tarsus sharp behind, its sides undivided and separated from the scutella in front by a groove, which is either naked or filled in with small scales. Voice usually harsh and unmusical.

(477) Blue Jay.

\section{Genus CYANOCITTA.}

(Cyanocitta cristata.)

A common resident, breeding throughout its range in the Province.

(484) Canada Jay.

Genus PERISOREUS.

(Perisoreus canadensis.)

A common resident in the northern part of the Province. Breeds in the northern part of its range.

\section{(486a) Northern Raven.}

\section{Subfamily CORVinf. (Crows.) \\ Genus CORVUS.}

(Corvus corax principalis.)

Tolerably common in the interior of the Province. Probably breeds in the remote forests towards James Bay.

(488) Common Crow.

(Corvus brachyrhynchos.)

Abundant resident in southern Ontario, summer resident in the northerly portions of the Province. Breeds throughout its range. 
Family icterid

Bill with the commissure angulated, usually lengthened, rarely shorter than head, straight or gently curved, without notch or rictal bristles; culmen usually extending upon the forehead, dividing the frontal feathers. Legs stout, adapted for walking in all our species, except those in Icterus.

Doliconyx and Molothrus are somewhat Finch-like, having the bill shorter than head.

(494) Bobolink.

\section{Genus DOLICHONYX.}

(Dolichonyx oryzivorous.)

Abundant summer resident. Breeds in the hay meadows throughout its range, which does not extend north of the cultivated country.

Arrives about the tenth of May, departs about the end of August.

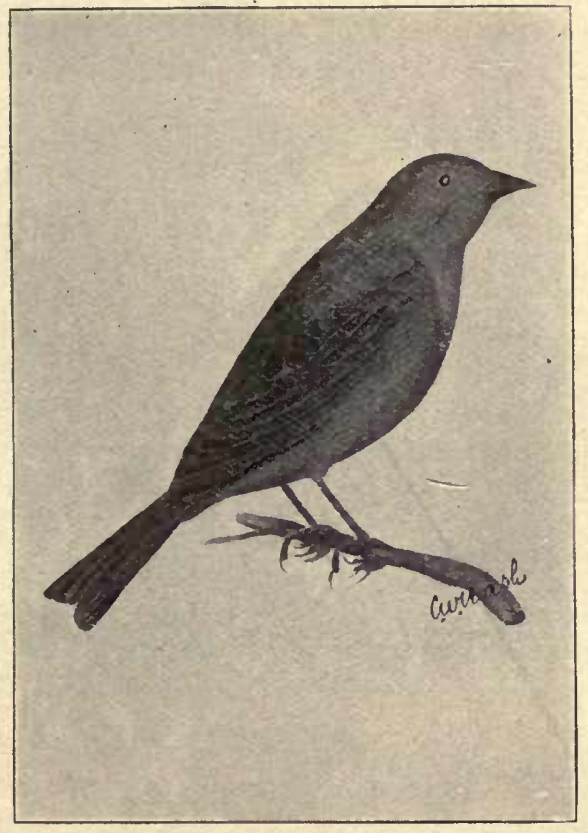

Cowbird.

\section{(495) Cowbird.}

\section{Genus MOLOTHRUS:}

(Molothrus ater.)

An abundant summer resident, deposits its eggs in the nests of other small birds. Breeds throughout its range. 
Arrives about the first of April and departs early in October.

This is the most injurious bird we have, as each egg deposited by it means the destruction of a whole brood of one of our beneficial species.

\section{GeNus XANTHOCEPHALUS.}

\section{(497) Yellow-headed Blackbird.}

(Xanthocephalus xanthocephalus.)

A very rare summer visitor from the western prairies.

\section{Genus AGELAIUS.}

(498) Red=winged Blackbird.

(Agelaius phœeniceus.)

A very abundant summer resident, breeding in marshes or clover fields throughout its range.

Arrives about the middle of March, departs about the middle of October.

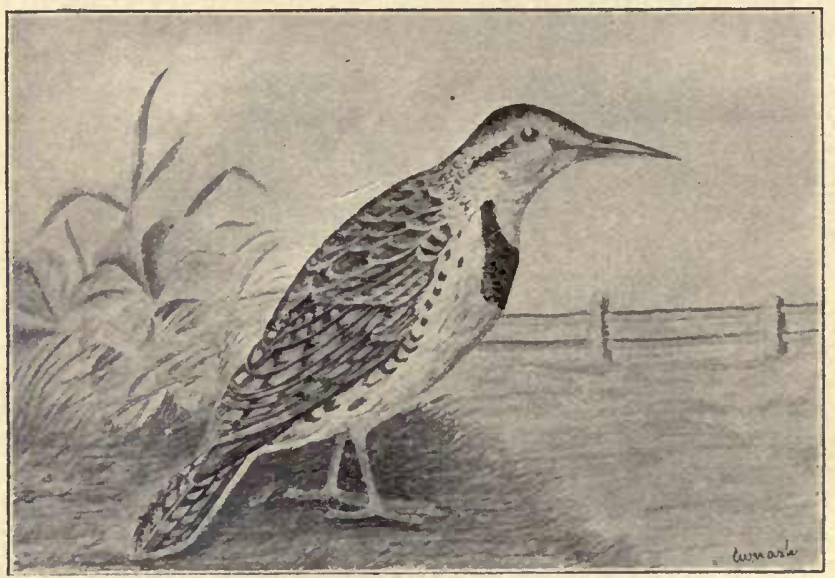

Meadowlark.

(૬० I) Meadowlark.

Genus STURNELLA.

(Sturnella magna.)

A common summer resident in southern Ontario, gradually extending its range northward as the land is cleared.

Breeds on the ground in meadows throughout its range.

Arrives towards the end of March, departs late in October or early in November. 
In mild seasons these birds stay very late, and I have on several occasions found small parties of them spending the winter here.

This species is of great value to the farmer, as it lives almost entirely in the cultivated fields and with us feeds upon the insects most injurious to the crops. The western form, S. m. neglecta, has been taken by $\mathrm{Mr}$. White at Ottawa.

\section{GENUS ICTERUS.}

(*) (506) Orchard Oriole.

(Icterus spurius.)

A regular, but not common, summer resident in the south-western counties, breeding in orchards and shrubberies. I found it every season in Haldimand and Norfolk and of late years a few pairs have regularly bred near Toronto.

\section{(507) Baltimore Oriole.}

(Icterus galbula.)

A common summer resident, breeding throughout its range in the Province.

Arrives early in May, departs about the end of August.

\section{Genus EUPHAGUS.}

\section{(509) Rusty Blackbird.}

\section{(Euphagus carolinus.)}

A common migrant through Ontario, it arrives in spring about the middle of April and passes northward without much delay; about the end of September they return and soon become abundant in the marshes, where they remain until the end of October.

Probably breeds in the northern part of the Province.

\section{Genus QUiscalus.}

(5 I I b) Bronzed Grackle.

(Quiscalus quiscula æneus.)

A common summer resident, breeding in colonies throughout its. range in the Province.

Arrives about the middle of March, departs early in October.

$$
\text { Family FRINGILLID } Æ \text { (Finches, Sparrows, etc.) }
$$

Bill cone shaped; the commissure angulated. Nostrils high up, exposed, or, in some northern species, partly covered by a ruff of small feathers. Tarsus scutellate in front with an undivided ridge behind.

All the Finches are granivorous, feeding largely on seeds when adult. None of them, however, reject insects whenever they can be ob- 
tained, and the young while in the nest are fed entirely upon insects which are carried to them by their parents. If there is any exception to this rule it will be in the genera Astragalinus and Spinus.

\section{GeNus HESPERIPHONA.}

(5r4) Evening Grosbeak.

(Hesperiphona vespertina.)

An accidental visitor from the west, sometimes occurring in winter.

\section{Genus PINICOLA.}

(5 I5) Pine Grosbeak.

(Pinicola enucleator leucura.)

An irregular winter visitor to southern Ontario; in some seasons quite common, in others entirely absent.

Probably breeds in the extreme north of the Province.

\section{GeNus CARPODACUS.}

(5I7) Purple Finch.

(Carpodacus purpureus.)

Common resident; breeds throughout its range in the Province. Most frequently noticed in early spring when the flocks move out of their winter quarters and visit the budding hardwood trees.

\section{Genus PASSER.}

\section{House Sparrow.}

(Passer domesticus.)

An importation from Europe, now an abundant resident, breeding wherever it occurs.

\section{Genus LOXIA.}

\section{(52I) American Crossbill.}

(Loxia curvirostra minor.)

A regular and sometimes an abundant winter visitor.

As I have found representatives of this species in southern Ontario in nearly every month of the year, I think they breed throughout the Province, wherever there are pine forests still standing.

(522) White-winged Crossbill.

(Loxia leucoptera.)

An irregular winter visitor to southern Ontario, never abundant.

Of regular occurrence in the nothern part of the Province, where it is said to be resident. 


\section{Genus ACANTHIS.}

\section{(*) (527) Greenland Redpoll.}

(Acanthis hornemannii.)

Probably occurs as a winter visitor, but I have no record of it other than that given by Mr. McIlwraith.

$\left({ }^{*}\right)$ (527a) Hoary Redpoll.

(Acanthis hornemannii exilipes.)

A somewhat irregular winter visitor, occurring in varying numbers at any time between September and May.

(528) Common Redpoll.

(Acanthis linaria.)

Generally common in winter, but sometimes entirely absent.

Breeds in the far north; commonly near Hudson's Bay.

$\left(^{*}\right)$ (528a) Holboll's Redpoll.

(Acanthis linaria holbœli.)

Occurs in winter sparingly with the other Redpolls.

(*) (528b) Greater Redpoll.

(Acanthis linaria rostrata.)

Occurs in winter sparingly with the other Redpolls.

\section{Genus ASTRAGALINUS.}

(529) American Goldfinch.

(Astragalinus tristis.)

A common resident in southern Ontario, more abundant in summer than in winter, a large number going south at the approach of cold weather.

\section{Genus SPINUS.}

(533) Pine Siskin. (Pine Finch.)

(Spinus pinus.)

A regular and sometimes an abundant winter visitor, which sometimes remains during the summer and breeds here. Nests have been found in many localities.

\section{Genus PASSERINA.}

(534) Snow Bunting. (Snowbird.)

(Passerina nivalis.)

A common winter visitor. Arrives about the end of October, departs about the middle of March.

Breeds in the Arctic regions. 
(536) Longspur.

\section{Genus CALCARiUS.}

(Calcarius lapponicus.)

An irregular winter visitor most frequently found in late autumn and early spring.

Breeds in the Arctic regions.

Genus POCECETES.

(540) Vesper Sparrow. (Baywing.)

(Poœcetes gramineus.)

An abundant summer resident. Breeds throughout its range in the Province.

Arrives about the middle of April, departs early in October.

\section{Genus PASserculus.}

(542a) Savanna Sparrow.

(Passerculus sandwichensis savanna.)

A common summer resident, breeding throughout its range in the Province.

Arrives about the middle of April, departs early in October.

\section{Genus COTURNICULUS.}

$\left(^{*}\right)$ (546) Grasshopper Sparrow.

(Coturniculus savannarum passerinus.)

A regular, but not a common summer visitor to south-western Ontario which has, on two occasions, been taken as far east as Toronto.

$\left(^{*}\right)$ (547) Henslow's Sparrow.

Genus AMMODRAMUS.

(Ammodramus henslowii.)

This bird has been recorded by Mr. W. E. Saunders as a summer resident of south-western Ontario, and by Mr. Fleming as occurring and apparently breeding near Lake Joseph, Muskoka.

$\left(^{*}\right)$ (548) Leconte's Sparrow.

(Ammodramus leconteii.)

An accidental visitor from the western prairies.

Mr. J. H. Ames has a specimen which was taken at Toronto.

(549. I) Nelson's Sparrow.

(Ammodramus nelsoni.)

A regular, but not a common, visitor in autumn to the neighbourhood of Toronto. Rare in spring.

$\left(^{*}\right)$ (549. ra) Acadian Sharp-tailed Finch.

(Ammodramus nelsoni subvirgatus.)

An accidental visitor to the eastern part of the Province. 


\section{Genus CHONDESTES.}

(*) $\left(55^{2}\right)$ Lark Sparrow.

(Chondestes grammacus.)

A regular, but not a common, summer resident of some localities in southern Ontario. I find a few pairs near Toronto every season.

Breeds where it occurs.

\section{GENUS ZONOTRICHIA.}

(554) White=crowned Sparrow.

(Zonotrichia leucophrys.)

A common migrant, arriving about the tenth of May and soon passing northward, returning towards the end of September and departing southward late in October.

Breeds in the far north.

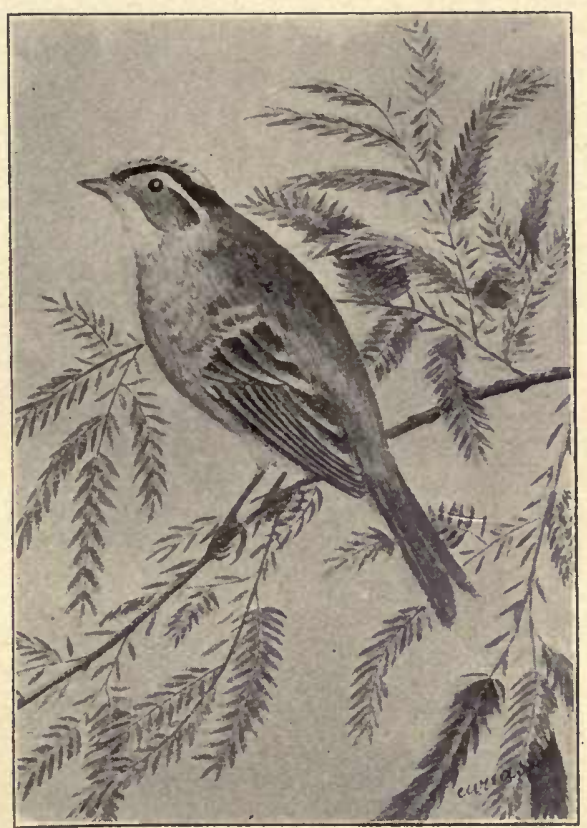

White-throated Sparrow.

(558) White=throated Sparrow. (Peabody.)

(Zonotrichia albicollis.)

Very abundant during the migrations and a regular, though not a common, summer resident in southern Ontario, where a few pairs always remain to breed.

Arrives about the end of April, departs southward early in October. 


\section{(559) Tree Sparrow.}

\section{GENUS SPIZELLA.}

(Spizella monticola.)

A common winter visitor. Arrives early in October, departs late in April.

Breeds from our northern limit northwards.

(560) Chipping Sparrow. (Hairbird.)

(Spizella socialis.)

An abundant summer resident. Breeds throughout its range in the Province.

Arrives about the middle of April, departs in September.

$\left({ }^{*}\right)(56$ I) Clay=coloured Sparrow.

(Spizella pallida.)

One specimen recorded by Mr. Saunders as having been taken by him near London. I found it abundant on the scrubby prairie of Manitoba, which is its proper habitat.

(563) Field Sparrow.

(Spizella pusilla.)

A common summer resident in suitable places in southern Ontario. Breeds throughout its range.

Arrives about the middle of April, departs early in October.

(567) Junco.

\section{Genus JUNCO.}

\section{(Junco hyemalis.)}

A common resident. Breeds throughout its range in the Province, but is most abundant in the spring and late autumn migrations.

\section{(58I) Song Sparrow.}

\section{Genus MELOSPIZA.}

\section{(Melospiza cinerea melodia.)} Province.

An abundant summer resident; breeds throughout its range in the

Arrives about the middle of March, departs late in October.

Some few always remain through the winter in sheltered places along our southern border, but as at that season they are very quiet, they are not often observed.

\section{(583) Lincoln's Sparrow.}

(Melospiza lincolni.)

A regular, but never a common visitor; perhaps breeds here, but so far I have never found it between May and September. It frequently accompanies the White-crowned Sparrows. 


\section{(584) Swamp Sparrow.}

\section{(Melospiza georgiana.)}

A very abundant summer resident in marshes; breeds throughout its range in the Province.

Arrives about the middle of April, departs early in November.

\section{Genus PASSERELLA.}

\section{(585) Fox Sparrow.}

(Passerella iliaca.)

A very rapid migrant. Large numbers pass through southern Ontario about the middle of April, seldom resting here for more than a day or two. In the autumn a few are always to be found, but they are not common at that season. Breeds in the far north.

This is one of the most beautiful songsters that visit us.

\section{GenUs PIPILO.}

\section{(587) Towhee.}

(Pipilo erythropthalmus.)

An abundant summer resident in the woods of southern Ontario and one which is extending its range as the land is brought under cultivation. Breeds wherever it occurs.

Arrives about the end of April, departs early in October.

(593) Cardinal.

\section{Genus CARDinALis.}

(Cardinalis cardinalis.)

A rare summer resident of the south-western counties. Stragglers have been taken at various places as far east as Toronto.

\section{Genus ZAMELODiA.}

\section{(595) Rose-breasted Grosbeak.}

(Zamelodia ludoviciana.)

A tolerably common summer resident. Breeds in the woods throughout its range in the Province.

Arrives about the middle of May, departs towards the end of August. This is one of the few birds that will eat the Colorado Potato-beetle.

(589) Indigo Bunting.

\section{Genus Cyanospiza.}

(Cyanospiza cyanea.)

A common summer resident; breeding throughout its range in the Province.

Arrives early in May, departs about the end of August.

$5 \mathrm{~B}$ 


\section{(*) (604) Dickcissel.}

\section{GeNus SPIZA.}

(Spiza americana.)

Mr. Saunders has recorded the occurrence of this bird in southwestern Ontario as a summer resident, and I have heard of it at other points along our southern boundary.

\section{Family TANagride. (The Tanagers.)}

Bill in our species stout, finch-like, considerably longer than broad, and more or less evidently toothed near the middle of upper mandible. Tarsus scutellate; legs short, claws long. Colours brilliant in the males.

(608) Scarlet Tanager.

\section{Genus PIRANGA.}

(Piranga erythromelas.)

Tolerably common summer resident; breeding throughout its range in the Province.

Arrives early in May; departs towards the end of August.

$\left(^{*}\right)$ (6ro) Summer Tanager.

(Piranga rubra.)

A very rare visitor to the south-western part of the Province. Stragglers have been taken at various places as far east as Toronto.

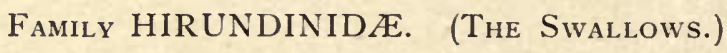

Bill short, broad, triangular, depressed, the gape wide and about twice as long as the culmen, reaching to about opposite the eyes, similar in its form to that of the Swifts and the Goatsuckers, with which birds, however, the Swallows have no affinity. Rictus without bristles; wings very long and pointed, secondaries very short. Tail more or less forked. Feet weak; tarsus scutellate. Plumage compact, and more or less lustrous.

All are remarkably strong on the wing, and while with us entirely insectivorous.

The economic importance of these birds is very great; without them the smaller winged insects would multiply to such an extent as to become an unbearable nuisance to men and animals; for it is, I believe, to these birds chiefly that we are indebted for our freedom, in the cleared and cultivated parts of the country, from the swarms of midges, black flies, and gnats of various kinds that so abound in the woods.

These birds seem to have a great predilection for the society of men, partly because the clearing he makes in a forest country opens up to them the necessary space for feeding grounds and partly because the 
buildings he erects afford them convenient nesting-places, of which the House Sparrow unfortunately is dispossessing them.

\section{(6I I) Purple Martin.}

Genus PROGNE.

\section{(Progne subis.)}

A common summer resident; breeding throughout its range in the Province.

Arrives about the fifteenth of April, departs early in September.

This is one of the birds which appears to be rapidly decreasing in southern Ontario and increasing northward and in Manitoba as the land is sețtled.

\section{GeNus PETROCHELIDON.}

(612) Cliff Swallow.

(Petrochelidon lunifrons.)

A regular summer resident, somewhat irregularly distributed, being abundant at some points and absent from others.

Breeds in colonies under the eaves of barns, etc., throughout its range in the Province.

Arrives early in May, departs in August.

\section{GeNus HIRUNDO.}

(613) Barn Swallow.

(Hirundo erythrogaster.)

A common summer resident, breeding in barns and outhouses throughout its range in the Province.

Arrives about the end of April, departs early in September.

\section{GENUS IRIDOPROCNE.}

(614) White-breasted Swallow. (Tree Swallow.)

(Iridoprocne bicolor.)

A common summer resident, breeding in holes in the side of buildings, nest boxes, etc., throughout its range in the Province.

Arrives quite early in April, departs about the end of September.

\section{GENus RIPARIA.}

(616) Bank Swallow. (Sand Martin.)

(Riparia riparia.)

An abundant summer resident, breeding in colonies in holes. in sandbanks, throughout its range in the Province.

Arrives about the beginning of May, departs about the middle of September. 


\section{GENús STELGIDOPTERYX.}

(*) (617) Rough-winged Swallow.

(Stelgidopteryx serripennis.)

A rare summer resident of our southern border, where it has been found as far east as Toronto.

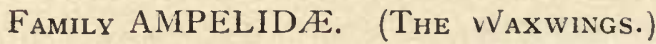

Bill stout, triangular, depressed, decidedly notched and hooked, with the gape very wide. Tarsus short, with the lateral plates more or less subdivided.

Our species are both crested birds with soft plumage of a beautiful cinnamon drab colour; sometimes the ends of the secondaries and of the tail feathers also, are tipped with horny appendages, looking like red sealing wax. These appendages are no indication of age or sex.

They feed on insects and soft fruits.

\section{Subfamily AMPHELINÆ. (WaxwiNgs.)}

\section{GENus AMPELIS.}

\section{(618) Bohemian Waxwing.}

(Ampelis garrulus.)

An irregular winter visitor, never abundant. Breeds in the northwest.

(619) Cedar Waxwing. (Cherry Bird.)

(Ampelis cedrorum.)

A resident species, common and generally distributed in summer; irregular in winter, its movements at that season probably depending upon the food supply.

Breeds throughout its range in the Province.

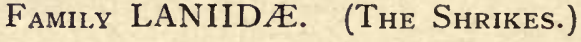

Bill hawklike, very strong, the upper mandible toothed and abruptly hooked at the tip; both mandibles distinctly notched. Wings short, rounded. Tail long. Tarsus scutellate on the outside as well as in front.

Their habits corresponding with the form of the bill, are similar to those of birds of prey. They have a remarkable habit of impaling small animals on thorns and leaving them there. 
(62 I) Northern Shrike.

\section{GENUS LANIUS.}

(Lanius borealis.)

A regular, but not abundant, winter visitor. The bulk of them breed in the north, but nests have been found at various places in southern Ontario.

Arrives in October, departs in April.

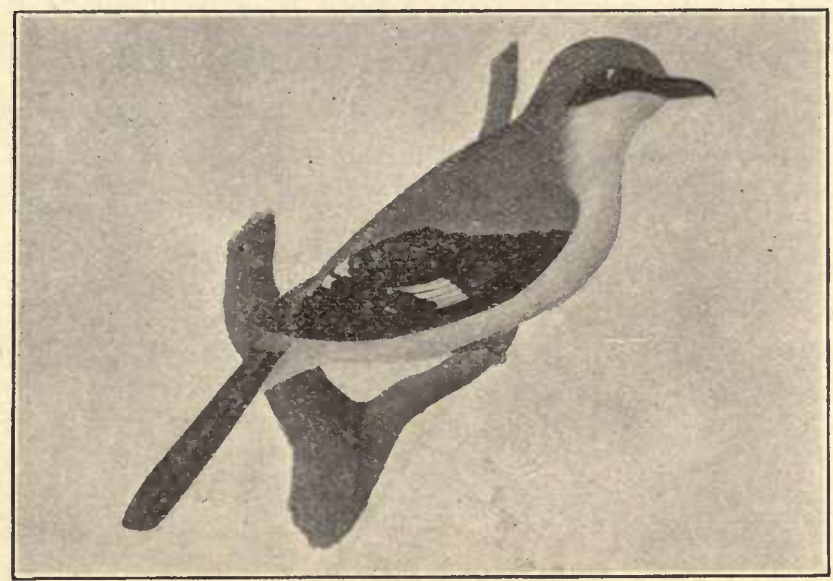

Migrant Shrike.

(622e) Migrant Shrike.

(Lanius ludovicianus migrans.)

A regular but not abundant summer resident. Breeds throughout its range in the Province.

Arrives early in April, departs about the end of August.

\section{Family VIREONIDÆ. (Vireos.)}

Bill shorter than head, stout, compressed, decidedly notched and hooked. Rictus with bristles. Nostrils exposed, overhung by a scale, reached by the bristly frontal feathers. Tarsus scutellate; toes joined at base for the whole length of basal joint of middle one, which is united with the basal joint of the inner and the two basal joints of the outer. All are insectivorous.

\section{(624) Red=eyed Vireo.}

\section{Genus VIREO.}

(Vireo olivaceus.)

A common summer resident in woods and orchards. Breeds throughout its range in the Province.

Arrives early in May; departs towards the end of September. 
(626) Philadelphia Vireo.

(Vireo philadelphicus.)

Tolerably common summer resident; breeds throughout its range in the Province.

Arrives about the middle of May, departs at the end of September.

(627) Warbling Vireo.

(Vireo gilvus.) vince.

Common summer resident; breeds throughout its range in the Pro-

Arrives about the middle of May; departs in September.

This species seems to prefer shrubberies and shade trees in city streets to the seclusion of the woods.

(628) Yellow=throated Vireo.

(Vireo flavifrons.)

An uncommon summer visitor which probably breeds with us, though I have no actual record of the discovery of its nest here.

Arrives about the beginning of May, departs early in September.

(629) Blue-headed Vireo. (Solitary Vireo.)

(Vireo solitarius.) interior.

A regutar migrant in spring and autumn. Probably breeds in the

Arrives early in May, departs at the end of September.

$\left({ }^{*}\right)(63$ I) White=eyed Vireo.

(Vireo noveboracensis.)

Mr. W. L. Kells has recorded the capture of one specimen near Listowel, in the middle of October, 1890 , and $\mathrm{Mr}$. Hobson has taken another near Woodstock. I have heard of no others.

\section{Family MNIOTILTIDÆ. (Wood Warblers.)}

Bill usually rather slender, notched or not; the commissure not angulated at base as in Fringillidæ, nor toothed in the middle; the end not notched and abruptly hooked, as in Vireonidæ; the gape not broad and reaching to the eyes, as in Hirundinidæ. The Warblers are all small birds, usually of brilliant colouration, but the sexes are unlike and the variations due to age and season are great, so that the identification of immature birds is sometimes troublesome.

All are insectivorous and of great value to the horticulturist, as they glean their insect food chiefly from the foliage and twigs of trees. 


\section{Genus MNIOTILTA.}

\section{(636) Black and White Warbler.}

(Mniotilta varia.)

A very common summer resident, breeding throughout its range in the Province.

Arrives about the first of May, departs early in September.

\section{GENUS PROTONOTARIA.}

(*) (637) Prothonotary Warbler.

(Protonotaria citrea.)

Mr. McIlwraith has recorded the capture of one specimen near Hamilton in May, 1888, which is all I have heard of.

\section{GENus HELMINTHOPHILA.}

(*) (642) Golden=winged Warbler.

(Helminthophila chrysoptera.)

A rare summer visitor recorded from several places in the southern and western counties and Mr. Kells reports having found it breeding near Listowel.

(645) Nashville Warbler.

(Helminthophila rubricapilla.)

A common migrant. Breeds sparingly in southern Ontario and no doubt regularly in the interior.

Arrives early in May, departs early in uctober.

$\left(^{*}\right)$ (646) Orange-crowned Warbler.

(Helminthophila celata.)

A rare summer visitor.

(647) Tennessee Warbler.

(Helminthopula peregrina.)

A regular, but not a very common, visitor in spring. I have not found it at any other, season.

Arrives about the middle of May.

\section{Genus COMSOTHLYPIS.}

(648) Parula Warbler.

(Compsothlypis americana usneæ.)

A common spring and summer migrant. Probably breeds in the interior.

Arrives about the fifteenth of May; departs towards the end of September. 


\section{GeNus DENDROICA.}

(650) Cape May Warbler.

(Dendroica tigrina.)

A rare summer visitor; most frequently seen in the spring. About three years ago I met with rather a large flock of them in the autumn migration, the only time I have seen them at that season. Probably breeds in the interior, as nests have been found in New Brunswick and in Maine.

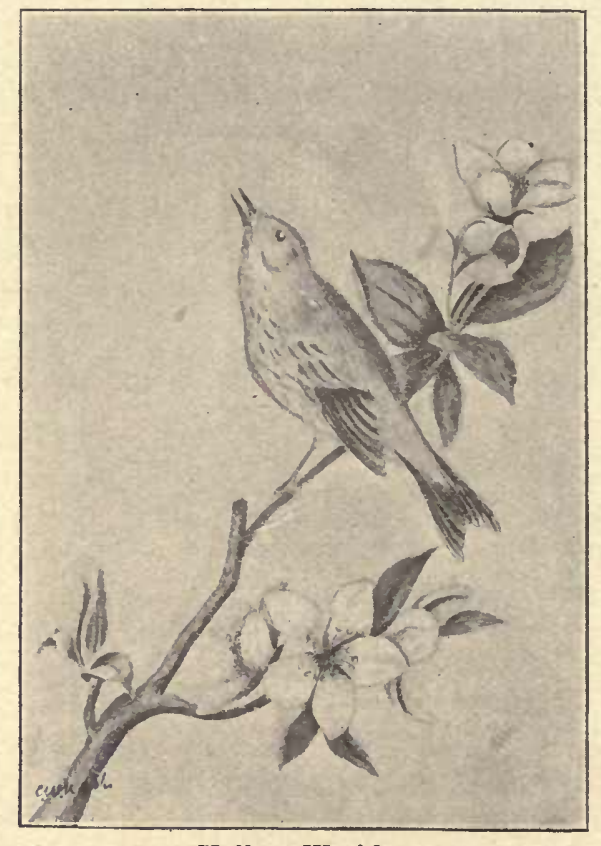

Yellow Warbler.

(652) Yellow Warbler.

(Dendroica æstiva.)

A very abundant summer resident. Breeds throughout its range in the Province.

Arrives early in May, departs about the end of August.

(654) Black-throated Blue Warbler.

(Dendroica cærulescens.)

Common in the migrations in southern Ontario, breeding sparingly in the south and more commonly in the interior.

Arrives early in May; departs at the end of September. 
(655) Myrtle War̉bler. (Yellow-rumped Warbler.)

(Dendroica coronata.)

An abundant migrant in the south. Breeds in the interior.

Arrives towards the end of April; departs about the end of the first week in October.

(657) Magnolia Warbler.

(Dendroica maculosa.)

An abundant migrant. Breeds from central Ontario northward.

Arrives early in May; departs about the end of September.

$\left(^{*}\right)\left(65^{8}\right)$ Cerulean Warbler.

(Dendroica cerulea.)

A regular, but rare, summer resident, most frequently seen in the south-western counties. Breeds throughout its range in the Province.

(659) Chẹstnut=sided Warbler.

(Dendroica pennsylvanica.)

A common summer resident. Breeds throughout its range in the Province.

Arrives early in May; departs early in September.

(66o) Bay-breasted Warbler.

(Dendroica castanea.)

A regular, but never a common, migrant in spring. Breeds in the interior.

I have but seldom met with this species in the autumn.

Arrives early in May; departs at the end of September.

(661) Black=poll Warbler.

(Dendroica striata.)

A regular, but not generally a common, migrant in spring and autumn. Breeds in the north, probably from our boundary to the tree limit.

Arrives about the twentieth of May; departs at the end of September

(662) Blackburnian Warbler.

(Dendroica blackburniæ.)

A tolerably common spring and autumn migrant in southern Ontario. Probably breeds in the interior, as it has often been observed during the summer months in central Ontario.

Arrives early in May; departs at the end of September.

(667) Black=throated Green Warbler.

(Dendroica virens.)

A common summer resident, breeding throughout its range in the Province.

Arrives early in May; depart's early in October. 
(*) (670) Kirtlan'd's Warbler.

(Dendroica kirtlandi.)

On the 16th of May, 1900, Mr. J. H. Samuel took a bird of this species near Toronto, the only one I have heard of so far. It may yet be found breeding in the interior of the Province, as it does so regularly in Michigan. It is, however, a very rare species everywhere.

(67I) Pine Warbler.

(Dendroica vigorsii.)

An irregular summer resident, sometimes common and in other seasons scarce.

Breeds throughout its range in the Province.

Arrives towards the end of April; departs in September.

(672) Palm Warbler.

(Dendroica palmarum.)

A tolerably common migrant in spring and autumn. Probably breeds in the northern part of the Province.

Arrives early in May; departs about the first of October.

Our form may be referable to D. p. hypochrysea. Specimens taken by me vary very much in the brilliancy of the yellow coloring.

\section{$\left({ }^{*}\right)(673)$ Prairie Warbler.}

(Dendroica discolor.)

A very rare visitor, two specimens of which were taken near Toronto in May, I90o, one each by Messrs. Samuel and Ames. Since then it has been found in south-western Ontario by Mr. Klugh.

\section{Genus SEIURUS.}

(674) Oven Bird. (Golden-crowned Thrush.)

(Seiurus aurocapillus.)

An abundant summer resident in woods. Breeds throughout its range in the Province.

Arrives early in May; departs about the first of September.

(675) Water Thrush.

(Seiurus noveboracensis.)

A common summer resident. Breeds in the interior of the Province. Arrives early in May; departs early in September.

(676) Louisiana Water Thrush.

(Seiurus motacilla.)

A rare summer visitor along our southern border as far east as Toronto. 


\section{Genus GEOTHLYPIS.}

(*) (677) Kentucky Warbler.

(Geothlypis formosa.)

An accidental visitor. One specimen taken by Mr. Robert Elliott near Bryanston, Middlesex, in May, 1898.

\section{(678) Connecticut Warbler.}

(Geothlypis agilis.)

A rare summer resident. Mr. W. L. Kells records having found nests near Listowel, and I have seen and watched the birds here in summer, but failed to discover their nesting place.

Arrives about the twentieth of May; departs at the end of August.

(679) Mourning Warbler.

(Geothlypis philadelphia.)

A rather rare summer resident. Breeds throughout its range in the Province.

Arrives about the twentieth of May; departs at the end of August.

(68I) Maryland Warbler.

(Geothlypis trichas.)

A common summer resident. Breeds throughout its range in the Province.

Arrives about the tenth of May; departs at the end of September.

Our form may be referable to $\mathrm{G}$. $\mathrm{t}$. brachydactyla.

\section{Genus ICTERIA.}

(*) (683) Yellow=breasted Chat.

(Icteria virens.) vince.

A very rare summer resident of the south-western part of the Pro-

\section{Genus WILSONIA.}

(*) (684) Hooded Warbler.

(Wilsonia mitrata.)

A very rare summer visitor to our southern border.

(685) Wilson's Warbler.

(Wilsonia pusilla.)

A regular migrant in spring and autumn, sometimes occurring in considerable numbers. Breeds in the interior.

Arrives about the twentieth of May; departs early in September. 
(686) Canadian Warbler.

(Wilsonia canadensis.)

Common summer resident, breeds throughout its range in the Province.

Arrives early in May, departs at the end of August.

\section{Genus SETOPHAGA.}

\section{(687) American Redstart.}

(Setophaga ruticilla.)

A common summer resident, breeding throughout its range in the Province.

Arrives about the tenth of May; departs early in September.

\section{FAMily MOTACILlid E. (Pipits, etc.)}

Bill shorter than the head, very slender, straight, acute, notched at tip. Feet large, fitted for walking; hind claw long, little curved, as in the larks; inner toe cleft; basal joint of outer toe united with middle one; tarsus as in Oscines generally, ending in a sharp undivided ridge behind. Rictal bristles not conspicuous; nostrils exposed.

(697) American Pipit.

\section{GeNus ANTHUS.}

(Anthus pennsylvanicus.) spring.

An abundant migrant, more frequently seen in autumn than in

Breeds in the Arctic regions.

Arrives about the tenth of May and passes on northward very quickly. Early in September they return and remain until about the end of the first week in November.

\section{Family TROGLODYTIDÆ. (Wrens, Thrashers, etc.)}

Bill usually more or less slender, with or without a notch near the tip. Nostrils not covered by bristles. Tarsus scutellate, the plates usually distinct.

All are chiefly insectivorous, the Catbird being the only one which feeds upon cultivated fruit.

\section{Family Mimid Æ. (Thrashers, etc.)}

(*) (703) Mocking-bird.

\section{Genus MIMUS.}

(Mimus polyglottos.)

I include this species on the authority of Mr. McIlwraith, who has recorded the occurrence of two specimens in southern Ontario. 


\section{Genus Galeoscoptes.}

(;04) Catbird.

(Galeoscoptes carolinensis.)

A very common summer resident; breeds throughout its range in the Province.

Arrives at the end of April, departs early in October.

\section{Genus TOXOSTOMA.}

(705) Brown Thrasher. (Brown Thrush.)

(Toxostoma rufum.)

A common summer resident; breeds throughout its range in the Province.

Arrives at the end of April; departs early in October.

\section{Subfamily TROGLODYTIN $Æ . \quad$ (Wrens.)}

\section{GeNuS THRYOTHORUS.}

\section{(*) (718) Carolina Wren.}

(Thryothorus ludovicianus.)

Mr. McIlwraith has recorded the capture of a specimen at Mount Forest, and recently Mr. Klugh found a pair breeding here.

\section{Genus THRYOMANES.}

(*) (7 r9) Bewick's Wren.

(1'hryomanes bewickii.)

Mr. W. E. Saunders records having taken one specimen on the thirtwenth Decemóer, I898, near Appin, Ontario.

(72I) House Wren.

\section{GEENUS TROGLODYTES.}

(Troglodytes aëdon.)

A common summer resident, nesting about houses and farm buildings throughout its range in the Province.

Arrives about the first of May; departs early in October.

(722) Winter Wren.

\section{Genus OLBIORCHILUS.}

(Olbiorchilus hienalis.)

A summer resident. Breeds throughout its range in the Province; commonly in the interior and northward. 


\section{Genus CISTOTHORUS.}

\section{(*) (724) Short=billed Marsh Wren.}

(Cistothorus stellaris.)

A regular summer resident of the south-western part of the Province, but never abundant. Very rare elsewhere. I have taken two at Toronto and have since found a pair breeding there.

Breeds wherever found.

\section{GeNus TELMATODYTES.}

\section{(725) Longsilled Marsh Wren.}

(Telmatodytes palustris.)

A very abundant summer resident in marshes. Breeds throughout its range in the Province. tober.

Arrives at the beginning of May; departs about the middle of Oc-

\section{Family CERTHIID $Æ$. (Creepers.)}

Bill slender, decurved as long as head, without notch or bristles. Tarsus scutellate. Claws all very long, curved and compressed. Tail feathers pointed, with stiffened shafts, somewhat like the tail of a Woodpecker and similarly used for support.

Our only representative is a curious small bird which creeps about the trunks and larger branches of trees searching for insects hidden in the crevices of the bark.

\section{(726) Brown Creeper.}

\section{Genus CERTHIA.}

\section{(Certhia familiaris americana.)}

A common resident, most abundant in southern Ontario during the migrations.

Breeds occasionally in the southern portion of the Province and regularly in the interior and northward.

\section{FAMILy PARIDA. (Tits.)}

Bill not notched nor decurved; loral feathers bristly; nostrils concealed by dense tufts. Tarsus scutellate; plumage more or less lax, subject to few variations.

All are insectivorous, gleaning their food from the trunks and twigs of trees. They are invaluable guardians of the orchard and forest. 


\section{Family SITTID $Æ . \quad$ (Nuthatches.)}

\section{Genus SITTA.}

\section{(727) White=breasted Nuthatch.}

(Sitta carolinensis.)

A common resident. Breeds throughout its range in the Province, wherever there is heavy timber.

(728) Red-breasted Nuthatch.

(Sitta canadensis.)

A resident species, but most frequently observed during the migrations. In winter it is fairly common.

I once found a pair evidently breeding near Toronto, and it regularly breeds in the interior and northward.

\section{(735) Chickadee.}

\section{Subfamily PARIN Æ. (Titmice.)}

\section{Genus PARUS.}

\section{(Parus atricapillus.)} chard.

A very common resident and one of the most useful birds of the or-

Breeds throughout its range in the Province.

$\left({ }^{*}\right)$ (740) Hudsonian Chickadee.

(Parus hudsonicus.)

In southern Ontario this is only a very rare straggler from the north. As might be expected, it is more frequently seen in the Ottawa district than elsewhere.

Mr. Kay reports having seen a pair near Port Sydney, Muskoka, in November, 1892.

\section{Family SYlviid Æ. (Kinglets, Gnatcatchers, etc.)}

Bill slender, depressed at base, notched and decurved at tip. Rictus with bristles; nostrils oval. Tarsus usually booted, scutellate in Polioptilla. Basal joint of middle toe attached its whole length externally, half way internally.

\section{Subfamily REgulinÆ. (Kinglets.) \\ Genus REGULUS.}

\section{(748) Golden=crowned Kingiet.}

(Regulus satrapa.)

An abundant migrant and common winter resident.

Probably breeds in our northern forests, as it does in Massachusetts. 
(749) Ruby=crowned Kinglet.

(Regulus calendula.)

Common during the spring and autumn migrations. Scotia.

Probably breeds in the interior, as it is known to do so in Nova

I have never found this species here in winter.

\section{Subfamily POLiOPTILIN $\approx$. (Gnatcatchers.) \\ Genus POLIOPTILA.}

\section{(75 I) Blue-gray Gnatcatcher.}

(Polioptila cærulea.)

A rare summer resident of the south-western counties, which occasionally strays as far east as Toronto.

Breeds where it occurs.

\section{Family TURDid $Æ$ (Thrushes, Bluebirds, etc.)}

Bill generally rather long, not conical, usually with a slight notch near the tip; nostrils oval, not concealed, but nearly or quite reached by the bristly frontal feathers; rictus with bristles, which are well developed in most of our species; tarsus always booted, i.e., enveloped in a continuous plate, formed in the fusion of all the scutella; except two or three of the lowest. Toes deeply cleft, the inner one free, the outer united to the middle one, not more than half the length of the first basal joint.

Their food consists of insects and small fruit, chiefly wild berries growing in the woods.

\section{Subfamily TURDin E. (Thrushes.)}

(755) Wood Thrush.

\section{GeNuS HYLOCICHLA.}

(Hylocichla mustelina.) abundant.

Fairly well distributed throughout southern Ontario, but nowhere

Breeds wherever it occurs.

Arrives early in May, departs about the middle of September.

(756) Wilson's Thrush.

(Hylocichla fuscescens.)

An abundant summer resident in woodlands, breeds throughout its range in the Province.

Arrives early in May; departs at the end of August.

Mr. W. E. Saunders records the capture of a specimen of H. f. salicola at Ottawa in September, 1898. 


\section{(757) Gray=cheeked Thrush.}

(Hylocichla aliciæ.)

A common migrant in spring and autumn, breeds far north.

Arrives about the middle of May, departs early in October.

$\mathrm{Mr}$. Saunders states that a specimen of $\mathrm{H}$. a. bicknelli was taken by Mr. Robert Elliott near Bryanston, Ont., September 19th, 1898.

(758a) Olive-backed Thrush.

(Hylocichla ustulata swainsonii.)

A common migrant in spring and autumn. Breeds far north.

Arrives about the middle of April and soon goes on, returning in September and departing early in October.

(759b) Hermit Thrush.

(Hylocichla guttata pallasii.)

A common migrant in spring and autumn in southern Ontario, and a summer resident, breeding in the woods of the interior.

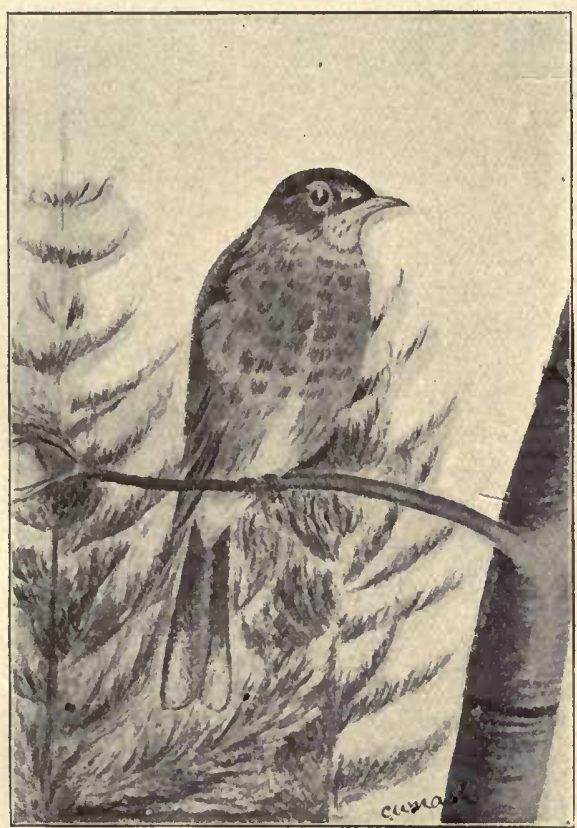

Robin.

Genus MERULA.

(761) American Robin.

(Merula migratoria.)

An abundant summer resident, breding throughout its range in the: Province.

6 в. 
Arrives early in March, the buik usually depart early in November, but some small flocks remain where food is plentiful until severe frost comes, and a few always remain in sheltered gardens all the winter.

$\left(^{*}\right)\left(7^{6}\right)$ Wheatear.

\section{Genus SAXICOLA.}

\section{(Saxicola onanthe.)}

A specimen of the subspecies, S. œ. leucorhoæ, was taken by $\mathrm{Mr}$. Tavernier at Beaumaris, Muskoka, in September, 1896 , having wandered out of its rangG.

(766) Bluebird.

\section{Genus SIALIA.}

(Sialia sialis.)

A common summer resident, breeding throughout its range in the Province.

Arrives about the middle of March, departs towards the end of October. 


\section{MAMMALS OF ONTARIO.}

Class MAMmalia. (The Mammals.)

A Mammal is a warm-blooded, air-breathing vertebrate, having the skin more or less hairy (rarely naked); viviparous; the young nourished for a time after birth by milk, secreted in the mammary glands of the mother; respiration never by means of gills, but after birth by lungs, suspended freely in the thoracic cavity, which is completely separated from the abdominal cavity by the diaphragm; heart with four cavities, a complete double circulation; blood warm. Brain case comparatively large, corresponding with the increased development of the brain.

\section{Order GLIRES. (The Rodents, or Gnawers.)}

Mammals with the incisor teeth chisel-shaped, adapted for gnawing; no canine teeth: a toothless space in the place of canines; molar teeth adapted for grinding; ears and eyes usually well developed. Food chiefly vegetable.

This is the largest order of Mammals both in number of species and in individuals. Most of the species are of small size, the Beaver being one of the largest now existing.

"Though a feeble folk, comparatively insignificant in size and strength, they hold their own in legion against a host of natural enemies, rapacious beasts and birds, by thęir fecundity, their wariness and cunning, their timidity and agility, their secretiveness, each after the means by which it is provided for exercising its instinct of self-preservation, among which insignificance itself is no small factor." (Coues.)

\section{Family LEPORID $£$. (The Hares.)}

A well-marked and widely distributed family represented in this Province by two well-known species. In all forms the ears are long, eyes large, and the tail short, bushy and recurved.

\section{Genus LEPUS.}

(1) Lepus nuttalli mallurus.

(Cotton-tail, Wood Hare, Gray Rabbit.)

This animal has gradually extended its range from the States south of us, into and over the entire Province, wherever the land is under cultivation, except the extreme northern and eastern portions. I do not know 
exact.y when it first appeared here, nor am I certain as to whether it first entered the country by crossing the Niagara River on the ice or by crossing at some point on the south-western boundary. I first saw it in the winter of $1871-72$ on the bank of the river at Niagara. During that winter the river had frozen completely across and their tracks showed that large numbers of rabbits had crossed to our side upon the ice bridge thus formed. For some years they increased and spread vey rapidly, but of late they have been so much pursued that in spite of the fact that they are remarkably prolific they seem to be rather decreasing than gaining in number.

To the fruit-grower these animals are somewhat objectionable because. of their habit of feeding upon the bark of young orchard trees; sometimes completely girdling and destroying them. The damage done by the Cotton-tail in this respect, however, is trifling compared with that done by mexdow mice, though I find that in many parts of the country the mischief done by the mice is generally charged against the Rabbits as they are commonly called.

The females produce two or three broods during the summer and each litter will contain from four to six young ones.

\section{(2) Lepus americanus.}

(Varying Hare, White Hare.)

Formerly this Hare was very abundant and generally distributed over the Province, but as the land has been brought under cultivation its range has become restricted. It is essentially an animal of the woods and wherever any extent of thick cover yet remains these Hares may still be found.

The Northern Hare is remarkable for the seasonal change which takes place in the color of its pelage. In summer it is of a dark reddish brown. In winter it becomes perfectly white.

\section{Family ERETHiZONTIDÆ. (The American Porcupines.)}

Fur mixed with bristly barbed spines; tip of muzzle with small hair; chiefly arboreal.

(3) Erethizon dorsalis.

\section{Genus ERETHIZON.}

(Canada Porcupine.)

Formerly common and generally distributed; now only found in the unsettled parts of northern Ontario.

There is a popular idea that this creature defends itself by shooting its quills at its enemies; this is a mistake. The Porcupine will sometimes strike a heavy blow with its tail, thereby driving the quills deeply into the flesh of an antagonist, but it has not the power to eject its quills, nor is it necessary, for its armature renders it almost invulnerable to its natural enemies as it is.

Its food consists of the tender bark, twigs, and buds of trees. 


\section{Family DipodidÆ. (The Jumping Mice.)}

Hind legs greatly elongated, adapted for taking long leaps; fore legs short. Tail very long.

\section{Genus ZAPUS.}

\section{(4) Zapus hudsonius.}

(Jumping Mouse.)

Formerly common and generally distributed, but of late years less frequently seen.

\section{Family MURide. (The Mice.)}

Representatives of this family are found in all parts of the world; species of the genus Mus being cosmopolitan, having accompanied man in all his migrations; all are of small size, the Muskrat being the largest found in Canada. Included in it are some of our most injurious farm pests.

\section{Genus FIBER.}

\section{(5) Fiber zibethicus.}

(Muskrat.)

Common everywhere about marshes, rivers, and streams. In marshes it builds houses for winter protection, but in streams it burrows in the banks, sometimes doing much injury to dams and other works constructed to hold water. It is omnivorous, feeding impartially upon animal and vegetable substances. Where fresh-water mussels (Unios) abound they form an important part of this animal's diet. Muskrats' fur when in prime condition is of high quality and if it was not so common would be more valued than it is at present.

\section{Genu's SYNAPTOMYS.}

(*) (6) Synaptomys cooperi. (Lemming Mouse.)

$\mathrm{Has}$ been found sparingly in western Ontario and northward.

\section{Genus MiCROTUS.}

(*) (7) Microtus pinetorum.

(Pine Mouse.)

The late Robert Elliott of Plover Mills recorded this mouse as common in the County of Middlesex; it is probably generally distributed in western Ontario, but has been overlooked. 


\section{(8) Microtus pennsylvanicus.}

(Meadow Mouse, Field Vole.)

Common everywhere and the most destructive animal we have.

This little animal which by its enormous increase during the last few years has done so much mischief in the Province, is the Short-tailed Field Vole, commonly known as the Meadow Mouse, though it is not really a Mouse at all. It is but rarely found in barns or outbuildings, even in winter, its favorite resorts being low meadows which support a rank vegetation. When for any reason the low meadows become unable to maintain the number of voles bred in them, the surplus will move out and spread all over the country, establishing themselves chiefly in the hay and grain fields, where they find favorable conditions during the summer. Food and shelter are everywhere and their natural enemies, which should keep them in check, having all been killed off, these prolific creatures multiply even more rapidly on the cultivated lands than they would in their original habitat. In winter, however, conditions are not so favorable to the Voles in the cultivated districts; the crops having been removed. leaves the fields comparatively bare and devoid of shelter except in the long grass and weed-grown fence lines, and here they take refuge; an old sunken rail fence being a favorite stronghold and an orchard in which a rank cover crop is left standing forming a perfect paradise for these secretive vermin. Under cover of the decaying vegetation in such places they drive a network of runways in every direction, secure from the obsevation of all but the creatures specialized by nature to prey upon them.

Field Voles are remarkably prolific animals, the females usually producing three or four litters a year, but in favorable seasons even more will be produced. During the last few years I have found nests containing young in every month from April to October, both inclusive. The litters generally contain from five to eight young, and indeed I have heard of ten, but so far have never found one as large as that.

These Voles do not burrow, but construct their nests upon the surface of the ground among rank vegetation or under logs, rails, etc. From these nests their runways are pushed in every direction until they form a perfect network over the land. During the growing season these runs are not easily observed unless specially sought for, but just as the snow is going off in the spring they are readily seen and an idea may then be formed of their numbers. Their food consists of grass, clover, grain (in all stages), fruit and the inner bark or cambium of young trees and bushes, the quantity they devour and spoil being a very heavy tax upon the farm in all seasons, and a particularly serious one when their numbers reach abnormal proportions.

From I 888 to 1892 part of Scotland was overrun by these Voles, the districts affected being parts of Roxburghshire, Selkirk, Peebles, Lanark and Dumfries. Altogether an area about sixty miles in length and twenty miles in breadth was devastated. In order to ascertain the cause of the outbreak and if possible provide a remedy a Departmental Committee was 
appointed by the British Board of Agriculture, of which the Earl of Minto, our late Governor-General, was a member. Evidence was given before this committee by about eighty farmers and shepherds and by several gamekeepers, their testimony proving conclusively (I) That the effect of the outbreak was to practically destroy all crops; (2) That the cause of the increase in the number of Voles was the destruction of hawks, owls, stoats, weasels, and other natural enemies of the voles; (3) That remedies are expensive and difficult of application. Poison on small enclosed areas was efficacious, but its application over farms, even if practicable, would be attended with much risk to other forms of life. Cats, though tried on a large scale, were of no service whatever. Large numbers wre killed by men and terrier dogs; systematic work by a man and several dogs giving better results than any other system employed.

The committee finally reported: "It would be difficult to condemn too severely the foolish action of those who allow or encourage the destruction of hawks and owls. It is with much satisfaction that your committee record that many farmers and land owners seem to have become convinced in late years that owls of all sorts are not only harmless, but most beneficial to agriculturists, and have issued orders for the preservation of those birds."

Our position in Ontario may at any time, if we are not careful, resemble that of the Scotch farmers in 1892 . It would be well, therefore, for our people to exert their best influence for the protection of the hawks and owls at once, in order to avert what may develop into a very serious calamity.

\section{Genus EVOTOMYS.}

\section{(*) (9) Evotomys gapperi.}

(Red-backed Vole.)

Probably generally distributed, but the only recent record I have is that of Mr. Allan Brooks, who took it in the County of Wellington.

\section{Genus PHENACOMYS.}

\section{("); (xo) Phenacomys latimanus.}

As this animal ranges from Labrador to western Ontario it should be found in the northern part of the Province, but $I$ have as yet no positive record of its occurrence here.

\section{Genus PEROMYSCUS.}

\section{(II) Peromyscus leucopus.}

(Deer Mouse, White-footed Mouse.)

Common and generally distributed. A very graceful, active species. It will occasionally take up its residence in a house or barn, and is then as troublesome as the common House Mouse. During the winter months it often occupies a deserted bird's nest, particularly those in hollow trees. 


\section{Genus MUS.}

(12) Mus decumanus.

(Brown Rat, Norway Rat.)

This destructive creature was introduced into America from Europe about 1775 and has since spread to all parts where white men have settled. Its most persistent enemy is the weasel. If one of these creatures takes up its abode near a barn all the rats must leave it, or be killed.

(13) Mus musculus.

(Common House Mouse.)

The date of its introduction into this country is not known, but the animal itself is only too familiar to all housekeepers in town and country. In proportion to its size it is capable of doing more mischief in barn and granary than any pest we have.

\section{Family CASTORIDA. (The Beavers.)}

\section{( i4) Castor canadensis.}

\section{Genus CASTOR.}

\section{(American Beaver.)}

A few years ago this valuable fur-bearing animal was perilously near extinction in our Province, but owing to the protection wisely afforded it, the Beaver is again becoming abundant in northern Ontario. In the Algonquin Park, where it is strictly preserved, they may be seen to great advantage.

\section{Family, SCiURidÆ. (The Squirrel.s.)}

\section{(15) Arctomys monax.}

\section{Genus ARCTOMYS.}

(Woodchuck, Ground Hog.)

Common and generally distributed. Sufficiently abundant in some localities to be a nuisance.

\section{GEÑus EUTAMIAS.}

(*) (I6) Eutamias quadrivittatus.

(Mountain Chipmunk.)

The eastern form of this species, E. q. neglectus, occurs commonly in the woods on the north shore of Lake Superior.

( 17$)$ Tamias striatus.

\section{Genus TAMIAS.}

(Chipmunk, Ground Squirrel.)

Common and generally distributed, the form generally found in Ontario is T. s. lysteri. Sub-species T. s. grisens occurs in the western part of the Province. 


\section{Genus SCIURUS.}

( 8 ) Sciurus hudsonicus.

(Red Squirrel.)

Common everywhere. This little creature seems to be able to hold its own even in the immediate vicinity of our cities, where it is subjected to all sorts of persecution. Where it is desired to protect small birds in gardens and shrubberies, this squirrel should not be allowed to frequent them, for it is a great destroyer of young birds in the nests.

\section{(19) Sciurus carolinensis.}

(Gray S̃quirrel, Black Squirrel.)

Formerly abundant in all the hardwood forests of southern and western Ontario, but the destruction of the woods and constant persecution have sadly reduced their numbers. Specifically the gray and the black forms are identical. Three sub-species have been distinguished, but as they all occur here and intergrade perfectly, it is not worth while considering them.

\section{GeNus SCIUROPTERUS.}

\section{(20) Sciuropterus volans.}

(Common Flying Squirrel.)

Common in southern Ontario, but not often seen, as it is nocturnal in its habits, never venturing from its retreat in some hollow tree, until after sunset. The so-called Flying Squirrels do not really fly, but the skin along their sides is capable of expansion so that it acts as a parachute.

During the winter this squirrel lies dormant, retiring to its nest in November and reappearing about the beginning of April.

(*) (2I) Sciuropterus sabrinus.

(Northern Flying Squirrel.)

This species ranges from the northern counties north to Hudson's Bay. The ranges of the two species probably overlap.

\section{Order INSECTIVORA. (The Insect Eaters.)}

A large group of small mammals, somewhat similar to the Carnivora, hut the individuals so small as to be unable to overpower vertebrate animals and therefore feeding chiefly upon insects.

\section{Family SORICIDA. (The Shrews.)}

Small mouse-like animals, but having the muzzle elongate; eyes and external ears developed. Feet not specially adapted for digging. 
All our species feed entirely upon insects and as they are extremely voracious they are of economic value. As yet they have been but little studied here, and time will probably add other species to our list.

(*) (22) Sorex fumens.

\section{Genus SOREX.}

(Sooty Shrew.)

Has been recorded from North Wellington by Mr. Allan Brooks and is probably generally distributed.

(32) Sorex personatus.

(Masked Shrew.)

Common and generally distributed.

(24) Blarina brevicanda.

Genus BLARINA.

(Mole Shrew.)

Common and generally distributed though not often seen. In this species the ears are small, not visible externally; it somewhat resembles a mole in general appearance, but its feet are quite different.

\section{Family TALPIDE. (The Moles.)}

Body stout and thick, without distinct neck. Eyes rudimentary, sometimes concealed. No external ears. Limbs very short; feet greatly expanded and provided with strong claws adapted for digging. Fur soft, compact and velvety. Noted for their extraordinary burrowing powers and the mounds which they throw up. Food principally underground insects.

\section{Genus PARASCALOPS.}

(*) (25) Parascalops breweri.

(Hairy-tailed Mole, Brewers' Mole.)

Rare, I have seen specimens from several counties, but its distribution is uncertain.

\section{Genus CONDYLURA.}

\section{(26) Condylura cristata.}

(Star-nosed Mole.)

Common and generally distributed, more particularly in low, moist ground. It is this species which throws up the mounds so often seen in meadows. It feeds upon all sorts of underground insects and earthworms and does much to keep in check the troublesome white grubs, wireworms and cutworms. 


\section{Order CHIROPTERA. (The Bats.)}

Mammals with the anterior limbs modified for flight by the elongation of the forearm and especially of four of the fingers, all of which are connected by a thin leathery membrane, which includes the hind feet and usually the tail. The Bats are nocturnal in their habits, going into retirement in the daytime and hanging head downward by their hind claws. All our species are entirely insectivorous and are of great economic value to farmers. In the minds of some people there is a strong prejudice against bats; these prejudices arise from superstition and ignorance, for our bats are incapable of injuring any human being. They do not entangle themselves in people's hair, nor do they carry bedbugs into houses as is commonly supposed, but they do help to rid us of large quantities of injurious insects and so are entitled to protection.

\section{FAMILY VESPERTILIONID $Æ$.}

Insectivorous Bats with the snout not appendaged; wing membranes ample; tail completely enclosed in the interfemoral membrane or only the last joint exserted; fur of peculiar structure, each hair with, a series of minute imbricated scales arranged in a spiral. All our bats belong to this family. Most of them lie dormant in winter, but two species migrate southward.

\section{Genus MYOTIS.}

(27) Myotis subulatus.

(Little Brown Bat.)

Common and generally distributed.

(*) (28) Myotis lucifugus.

I have one record of this species from Wellington, where it was taken by Mr. Brooks.

\section{GENUS LASIONYCTERIS.}

(29) Lasionycteris noctivagans.

(Silver Black Bat.)

Common and generally distributed, particularly abundant near the Lakes. Migrates southward in winter.

\section{Genus VESPERTILIO.}

\section{(30) Vespertilio fuscus.}

(Brown Bat, Dusky Bat.)

Common and widely distributed. 


\section{GENUS LASIURUS.}

(31) Lasiurus borealis.

(Red Bat.) Erie.

Common and generally distributed, particularly abundant near Lake

(*) (32) Lasiurus cinereus.

(Hoary Bat.)

This is our largest species and one that is seldom seen. Specimens have been recorded from various parts of the Province, but it is rare everywhere. Migrates southward for the winter.

\section{Order UNGULATA. (The Hoofed Mammals.)}

Herbivorous mammals provided with one to four enlarged and thickened claws or hoofs on each foot; molar teeth adapted for grinding.

\section{Family CERVIDÆ. (The Deer.)}

Horns deciduous, solid, developed from the frontal bone, more or less branched, covered at first by a soft hairy integument known as "velvet;" when the horns attain their full size, which they do in a short time, there arises at the base of each a ring of tubercles known as the "burr." This compresses and finally obliterates the blood vessels supplying the velvet:" which dries up and is rubbed off, leaving the bone hard and insensible. The horns or antlers are shed annually, the separation of the "beam" from its "pedicel" taking place just below the burr. Antlers are wanting in the female, except in the Caribou, but they are present in the male of all our species.' Stomach in four divisions as with ordinary ruminants.

\section{Genus ODOCOILEUS.}

\section{(33) Odocoileus americanus.}

(Red Deer, Virginia. Deer.)

Common and generally distributed in all unsettled districts. Ranges westward into eastern Manitoba.

\section{Genus CERVUS.}

\section{(34) Cervus canadensis.}

(Wapiti, "Elk.")

It seems certain that at one time the Wapiti was found in western Ontario, but it has become extinct. If it is ever found here now, it will be near the Manitoba border. In the west this animal is commonly and wrongly called the Elk, a name properly belonging to the next species. 
(35) Alces americanus.

\section{Gienus ALCES.}

(Moose, True Elk.)

Common in the wilds of Northern Ontario. The most splendid representative of wild animal life of the American continent.

(36) Rangifer caribou.

\section{GENUS RANGIFER.}

(Woodland Caribou, American Reindeer.)

This species is very abundant in extreme northern Ontario, occasionally coming south in winter as far as Lake Superior. On the treeless wastes of the Arctic regions, a sub-species, R. c. arcticus, the Barrenground Caribou, is found.

\section{Order FERAE. (The Flesh-eaters, or Carnivora.)}

Canine teeth distinct, conical; molars more or less adapted for cutting; toes provided with claws; skin covered with hair or fur; alimentary canal short.

\section{Family PROCYONIDE. (The Raccoons.)}

- Plantigrade animals of moderate size, with the body comparatively slender and the tail well developed. Snout more or less elongated.

\section{(37) Procyon lotor.}

\section{GENus PROCYON.}

(Common Raccoon.)

Common and generally distributed where sufficient bush is left to afford shelter for it.

\section{Family URSIDE. (The Bears.)}

Piantigrade animals having the body thick and clumsy. Tail rudimentary. Teeth broad and tuberculated, according with an omnivorous diet.

\section{(38) Ursus americanus.}

\section{Genus URSUS.}

\section{(Black Bear, Brown Bear, Cinnamon Bear.)}

Very variable in colour; there is, however, but one species found in this Province south of the Arctic regions. Formerly abundant and generally distributed, but now restricted to the unsettled districts.

\section{Family MUSTElide. (The Weasels.)}

Small, or medium-sized animals, some of which are strictly carnivorous, while others are omnivorous. Most species provided with glands which secrete a fetid liquid. In this family are many of the most valuable fur-bearing animals. 


\section{Genus LUTRA.}

(39) Lutra canadensis.

(American Otter.)

Formerly common and generally distributed; now restricted to the lakes and rivers in the northern districts. Having been much persecuted for the sake of its valuable fur it had become nearly extinct, but owing to proper protection its numbers have increased of late. Aquatic; feeds principally upon fish and frogs.

\section{GENUS MEPHITIS.}

(40) Mephitis mephitica.

(Common Skunk.)

Common and generally distributed. This offensive creature is only known to be condemned, but apart from its unpleasant odour and occasional raids upon hen's nests it has some good traits in its character. It feeds largely upon insects of all sorts and is particularly partial to the large white grubs and cutworms, which it scratches out and devours with avidity. Its fur is of excellent quality and is now dyed to imitate sable.

\section{Genus GULO.}

(4 I) Gulo luscus.

(Wolverene.)

Never very abundant and now rare. It is found only in the northern wilds remote from settlements.

\section{Genus MUSTELA.}

(42) Mustela americana.

(Pine Marten, Sable.)

Not uncommon in the northern forests. Its fur is much esteemed.

(43) Mustela pennantii.

(Fisher, Pekan.)

An inhabitant of the north woods which has been so persistently hunted that it is becoming scarce. Valued for its handsome fur.

\section{Genus LUTREOLA.}

\section{(44) Lutreola vison.}

(Mink.)

Common and generally distributed. Its fur is beautiful and valuable. The animal itself is a bloodthirsty marauder, killing and feeding upon everything it can overpower. As a destroyer of field mice it renders good service, but when it raids a hen-roost it is not so much appreciated. 


\section{Genus PUTORIUS.}

\section{(45) Putorius noveboracensis.}

(Ermine, Stoat.)

Common and generally distributed. Turns white in winter, when its fur becomes the Ermine of commerce. A fierce and bloodthirsty little animal, but of great economic value because it kills large numbers of rats, field mice and other destructive vermin; occasionally it makes a raid upon the hen-roost, but this does not occur very often, and on the whole the good it does far outbalances the evil.

\section{(46) Putorius cigonani.}

(Small Brown Weasel.)

Common throughout the Province. White in winter. In its habits resembling the last. Smaller and less powerful. It is decidedly a farmer's friend, as a check upon the increase of field mice and rats.

\section{Family CANIDA. (The Dogs.)}

Digitigrade carnivora with blunt non-retractile claws. Muzzle elongated in our wild species.

\section{Genus VULPES.}

(47) Vulpes pennsylvanicus.

(Red Fox.)

Common wherever it can find sufficient cover. A very variable species. Two well-known varieties are the Black or Silver Grey and the Cross Fox. These intergrade in all degrees and the extremes of each variety have been found in one litter.

Though the Fox is generally looked upon as injurious to the farmer by reason of its occasional raids upon the poultry yard, it should be remembered that its favorite and chief food is field mice; of these it destroys great numbers and is one of nature's great checks upon their undue increase.

\section{(48) Canis nubilus.}

\section{Genus CANiS.}

\section{(Wolf, Timber Wolf.)}

Very variable in colour, becoming almost white in the far north. Extinct in the older settled parts of the Province, but sometimes sufficiently common to be injurious in the northern counties. We sometimes see in the newspapers accounts of attacks upon travellers made by these animals. These are pure fiction. That the European wolf when pressed by hunger will sometimes attack a man is no doubt true, but so far there is no authentic case known where a wolf attacked a man in this country. They are very shy and cunning. No more difficult animal to shoot or trap exists in our woods. 


\section{Family felid}

Digitigrade carnivora. Claws compressed, very sharp, retractile; palms and soles hairy, with naked pads under each toe and the ball of the foot. Body compact, head short, broad, and rounded.

(49) Lynx canadensis.

\section{Genus LYNX.}

(Canada Lynx.)

Formerly common all through the Province. Now only found in the forested districts, its range extending north nearly to the timber line.

\section{(50) Lynx rufus.}

(Wild Cat.)

Nearly if not quite extinct. During the last twenty years I have seen specimens from nearly all our southern counties, to which its range seems to have been restricted.

$\left(^{*}\right)$ (5I) Felis concolor.

\section{Genus FELIS.}

(American Panther, Cougar.)

Now extinct in this Province, where it was never very abundant. There are many. old records of its capture along our southern border in the early settlement days, but its range does not appear to have extended very far north of our southern boundary. 


\section{INDEX TO SECTIONS}

\section{SECTION I.}

\section{FISHES.}

\section{A.}

PAGE.

Abramis

Acanthopteri

Acipenseridæo

Acipenser rubicundus

Alburnops

Alewives

Alewife

Allosomus

Alosa

"

sapidissima

Ambloplites

Ameiurus

$$
\text { rupestris }
$$

"6

lacustris

natalis

vulgaris

nebulosus

melas

Amiidæ

Amia

mmoalva

Amphiodon

Anacanthini

Anguillidæ

Anguilla chrysypa

Aphredoderidæ

Aphredoderus

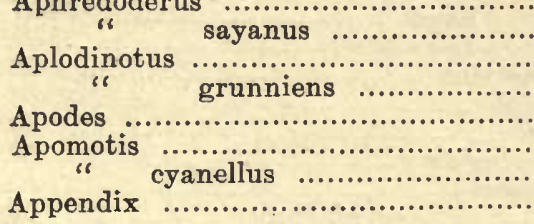

PAGE.

38

38

75

13

13

14

14

53

54

60

54

54

94

83

83

20,21

21

21

22

22

23

16

17

18

97

51

103

49

49

49

77

78

78

100

100

48

84

85

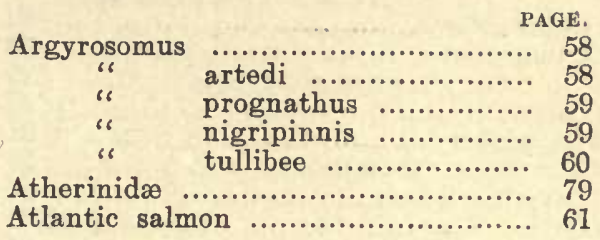

B.

Bass, Black ............................ 88

" Calico .............................. 82

" Grass .............................. 81

« Green ................................... 88

" Rock ...................................... 83

" Silver .................................. 81

" Speckled .............................. 82

" Striped ............................... 99

" White ................................ 99

، Yellow ............................. 88

Bill fish .................................... 15

Black Bass, The ...................... 87

" " Large mouthed ........... 87

" " Small mouthed .......... 88

" Catfish ................................ 23

" fin Whitefish .......................... 59

" head Minnow .......................... 35

"، nosed Dace ............................ 44

" sided Darters ......................... 93

" sided Darter .......................... 94

Blob ........................................ 101

Blue Darter ................................... 10.5

“ Pickerel .............................. 91

" Sunfish .................................... 85

Blunt-nosed Minnows ..................... 36

Boleosoma ................................ 95

" nigrum

"6 n. olmstedi ..................... 96

Bony fishes ............................ 19

Bowfins ................................. 16, 17

Bowfin ................................... 18

Bream ........................................ 38 


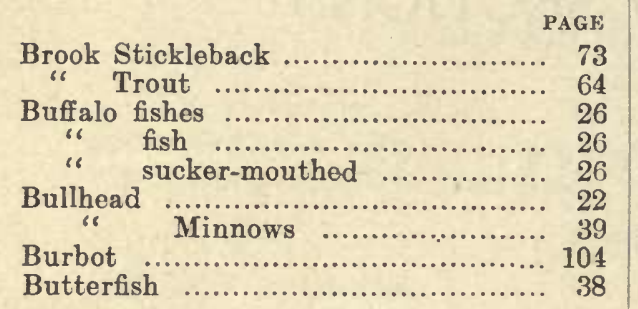

c.

Calico Bass ................................... 82

Campostoma ................................ 33

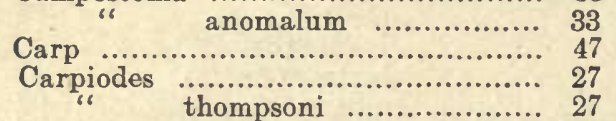

Carplike fishes ............................ 25

Carps, The .................................25-32

Carp Lake ................................ 27

" Suckers ..................................... 27

Catfishes .................................... 19

Catfish, Black .............................. 23

" Common ........................ 22

" Lake ............................... 21

" Long Jawed. .................... 22

“ Spotted .......................... 20

" Channel .............................20-21

" Stone ......................... 23-24

"، Yellow .............................. 21

Catostomidæ .................................. 25

Catostomus ................................ 28 " commersonii ................ 28

" catostomus .................... 28

" nigricans ...................... 29

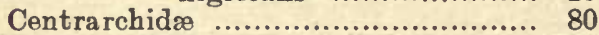

Chænobryttus .............................. 84

Channel Catfish ............................ $20-21$

Charrs, The ........................... 64

Chondrostei .................................... 13

Chriope …........................................ 39

Chrosomus ................................ 34

" erythrogaster ................ 34

Chub ....................................... 36

" Creek .................................. 37

" Lake ............................. 46

"S Suckers ............................ 30

Chubs, The ............................... 36

Cisco ...................................... 58

Ciscoes, The ............................. 58

Clinostomus .................................. 38

Cliola .............................................. 39

" vigilax

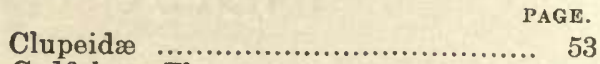

Codfishes, The ................................ 103

Common Mullet ............................. 32

" Pike ................................. 68

" Sucker …......................... 28

" Whitefish ........................ 56

Copeland's Darter ......................... 95

Coregonus ................................... 56

" clupeiformis .................... 56

" labradoricus ...................... 57

quadrilateralis ............... 56

Cottogaster .............................. 101

. copelandi .................... 95

Cottus ....................................... 101

" ictalops .......................... 101

Couesius ................................... 46

"1 plumbeus ............................ 46

Crappie ................................ 81

Creek Chub ............................... 37

Cristimover ..................................... 63

" namaycush .............. 63

Cycloganoidea .................................. 16

Cylindrosteus ............................ 16

Cynoperca ................................. 91

Cyprinella .................................. 41

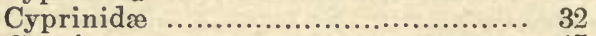

Cyprinus ................................ 47

D.

Dace

.

" Black-nosed ....................... 44

“ Horned ............................... 36-37

“ Long-nosed ....................... 44, 105

"6 Red-bellied ........................... 34

Darters .......................................... 93

Darter, Black-sided ...................... 94

" Blue ................................. 105

" Copelands ............................ 95

“ Johnny .............................. 95

" Manitou .............................. 93

" Northern .............................. 97

" Rainnbow ........................ 105

“ Sand ............................... 96-97

"6 Tessellated .......................... 95-96

Decactylus ................................. 28

Dogfish ....................................... 18, 66

Doré ............................................ 90

Dorosomidæ ….................................. 52

Dorosoma ............................... 52

cepedianum .............. 52 
PAGE.

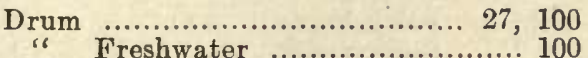

Drums, The

E.

Eels, The

Eel, American 48-49

Enchelycephali ............................ 49

Erimystax ............................... 45

Erimyzon .................................. 30

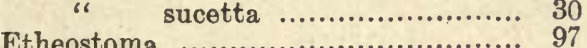

"6 boreale .......................... 97

Eucalia cœruleum ....................... ${ }_{72}$

" inconstans ......................... 73

Eupomotis ............................. 86

" gibbosus ..................... 86

Eventognathi ............................. 25

Exoglossum .............................. 46 maxillingua ................ 47

\section{F.}

Fathead Minnow

Fine-scaled Suckers ..................... 28

Fishes ................................... 7,10

Fontinus ............................... 71

Franklin's Sculpin ...................... 102

Freshwater Drum ........................ 100

" Killy ....................... 71

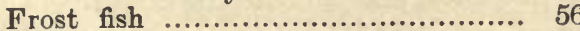

Fundulus .................................... 70 " diaphanus .................... 71

G.

Gadidæ 103

Ganoidei

Garfish

Gar-Pikes

Gar-Pike

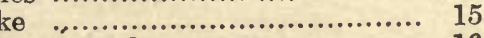

Gar, Short-nosed ........................... 16

Gaspereau .................................. 54

Gasterosteidæx ................................. 72

Gasterosteus ............................... 74

". bispinosus ................... 74

Gizzard Shad

Glossary ........................................ 106

Gold-eye

Gold Shad ....................................... 53

Golden Shiner .............................. 38

Grass Bass …................................. 81

Gray Trout

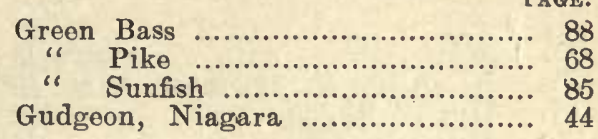

H.

Hadropterus ............................ 93

aspero ...................... 94

Haplomi …....................................... 65

Hemibranchii ............................. 71

Hiodon .................................. 51

"6 alosoides ............................ 51

"6 tergisus .......................... 51

Hiodontidæ .............................. 50

Hog Sucker ................................ 29

Horned Dace ............................. 36-37

" Pouts ........................... 20

Horny-heads .............................. 45

Hybopsis ............................. 45-46

" dissimilis ...................... 45

storerianus ................. 46

Hybognathus ............................ $34-35$

" nuchalis ................... 35

Hypentelium .............................. 29

Hyperoartii .............................. 8

I.

Ictalurus ................................ 20

" punctatus ........................ 20

Icthyomyzon ............................ 8

" concolor ................... 9

Ictiobus ................................. 26

"s bubalus ......................... 26

Isospondyli ….............................. 50

J.

Jackfish ................................... 69

Johnny Darter ......................... 95

K.

Kenoza ........................................ 68

Killifishes .............................. 70

Killifish ..................................... 71

Killy, Fresh-water ..................... 71

$\mathbf{L}$.

Labidesthes ............................ 79

sicculus .................... 79 


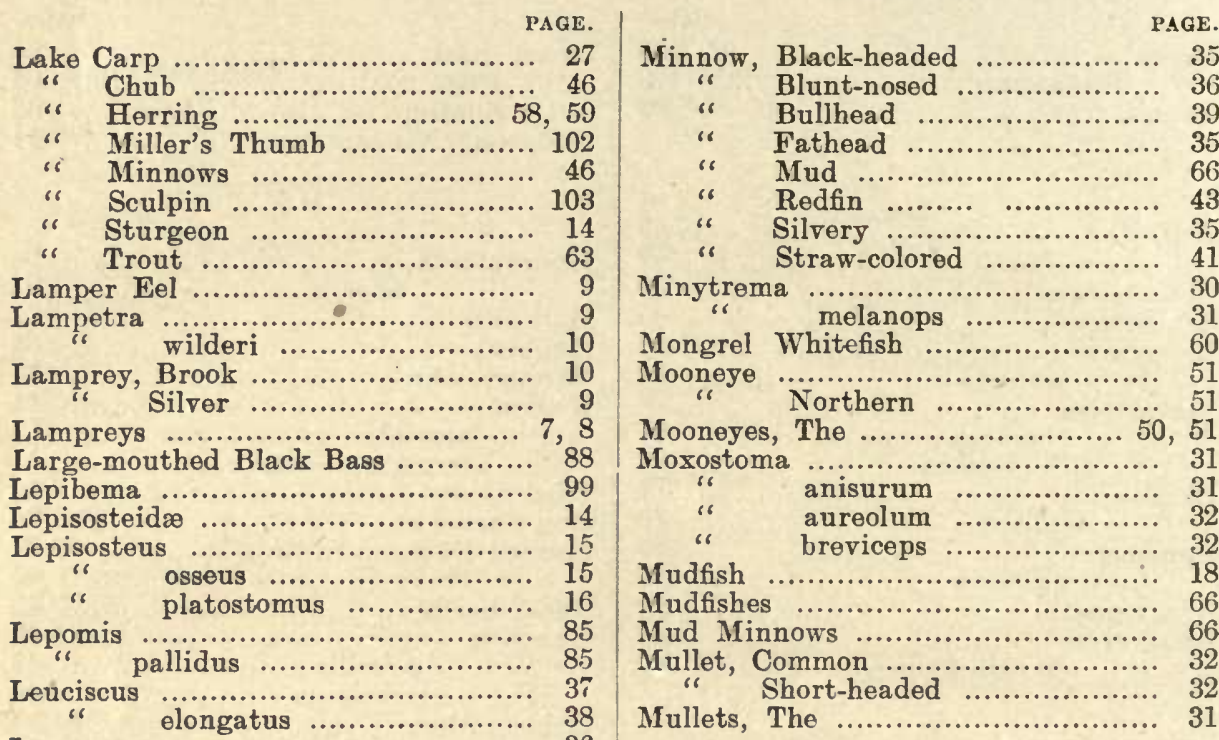

Leucosomus ................................ 36

Ling .......................................... 104

Lings, The ............................... 103

Log Perch ............................... 93

Log Perches .............................. 92

Long-Jaw Herring ...................... 59

" Jawed Catfish ..................... 22

" nosed Dace ...................... 44, 105

Loricati " Sucker .................... 28

Lota ........................................ 103

"6 maculosa ............................ 104

Luciidæ ...................................... 67

Lucius ......................................67, 68

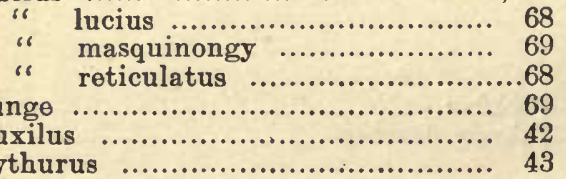

M.

Mad Tom ................................. 24

Manitou Darter ................................. 93

Marsipobranchii ............................. 8

Mascalonge ................................ 69

Mascalongus .................................. 69

Melanura .................................... 66

Micropterus .................................. 87

Miller's Thumb ............................. 101

Lake .................. 102

N.

Nematognathi .......................... 19

Niagara Gudgeon ....................... 44

Nivicola ................................ 97

Northern Mooneye ...................... 51

"، Pike ................................. 68

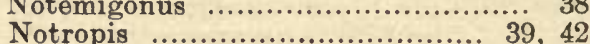

" atherinoides .................... 43

"، blennius ........................... 41

" cayuga .............................. 39

" cornutus ...................... 42

" fretensis ......................... 40

"، heterodon .......................... 40

"6 hudsonius ......................... 41

" jejunus ........................ 42

"s muskoka .......................... 40

"، rubifrons ....................... 43

" umbratilis ......................... 43

" volucellus ........................... 41

" whipplii ......................... 41

Noturus ........................................... 23

"6 flavus ........................... 24

o.

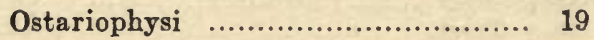


PAGE.

P.

Paddlefish

Paddlefishes, The

12

Pegedictus

Perca

"flavescens

Percesoces

Perches, Log

Perch, Log.

Perches, The

Perch, Pirate

$$
\text { "Trout }
$$

Percidæ

Yellow

Percina

Percoidea

caprodes zebra

Percopsis

Percopsid guttatus

Petromyzonidæ

Pickerel

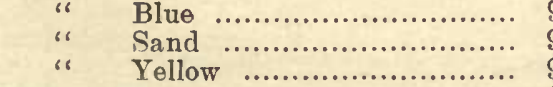

Pike, Common 68

"Green ............................. 68

" Northern ......................... 68

Pikelike fishes ............................ 65

Pikes. Gar ................................. 14

Pike Perches ............................... 90

Pikes, The .............................. 67

Pimephales ............................. 35

"

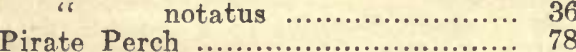

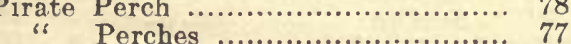

Pisces ................................. 7, 10

Plectognathi .............................. 100

Plectospondyli ............................ 25

Pœciliidre ................................... 70

Polyodon ............... 12

"s spathula .......................... 12

Polyodontidæ ............................ 11

Pomolobus

" chrysochloris ................. 53

"6 pseudoharengus $\ldots \ldots \ldots \ldots . . .54$

Pomoxis .............................. 81

"annularis ..................... 81

" sparoides $\ldots \ldots \ldots \ldots \ldots \ldots \ldots \ldots \ldots, 82$

Pouts, Horned

Prosopium

Pumpkin seed

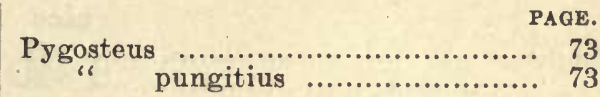

R.

Rainbow Darter ........................ 105

Red-bellied Dace ......................... 34

Redfin

"6 Minnow ............................. 43

Redhorse ................................. 32

" Suckers ...................... 31

Red-sided shiner .......................... 38

Rhegnopteri .............................. 99

Rhinichthys ............................. 44 " atronasus ................. 44

cataractæ $\ldots \ldots \ldots \ldots, 44,105$
idea $\ldots \ldots \ldots \ldots \ldots \ldots \ldots \ldots \ldots \ldots, 14$

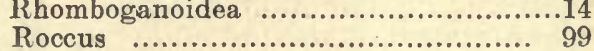

" chrysops .......................... 99

Rock Bass ............................. 83

" Sturgeon ...........................14

Round Whitefish ...................... 56

S.

Salmon, Atlantic ..................... 61

" Steelhead ...................... 62

"r Trout ............................ 63

Salmons, The ........................ 55, 61

Salmo $\ldots \ldots \ldots \ldots \ldots \ldots \ldots \ldots \ldots \ldots \ldots . . .61$

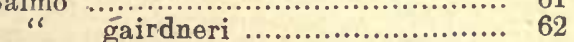

"6 salar ............................ 61

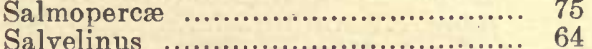

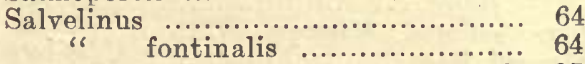

Sand Darters. The ................. 96, 97

Sand Pickerel ............................. 91

Sand Roller ............................. $\quad 76$

Sauger ................................. 91

Sault Whitefish .......................... 57

Schilbeodes .............................. 24

" gyrinus .................... 24

Sciænidæ ................................. 99

Sculpin ................................... 101

" Franklin's ..................... 102

"s Lake ........................... 103

Selachostomi $. . . \ldots \ldots \ldots \ldots \ldots \ldots \ldots \ldots \ldots \ldots, 11$

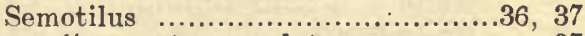

Serranidæ ............................... 98

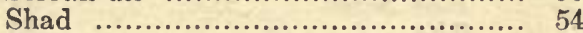

" Gizzard .......................... 52

" Gold ............................. 53

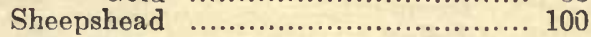




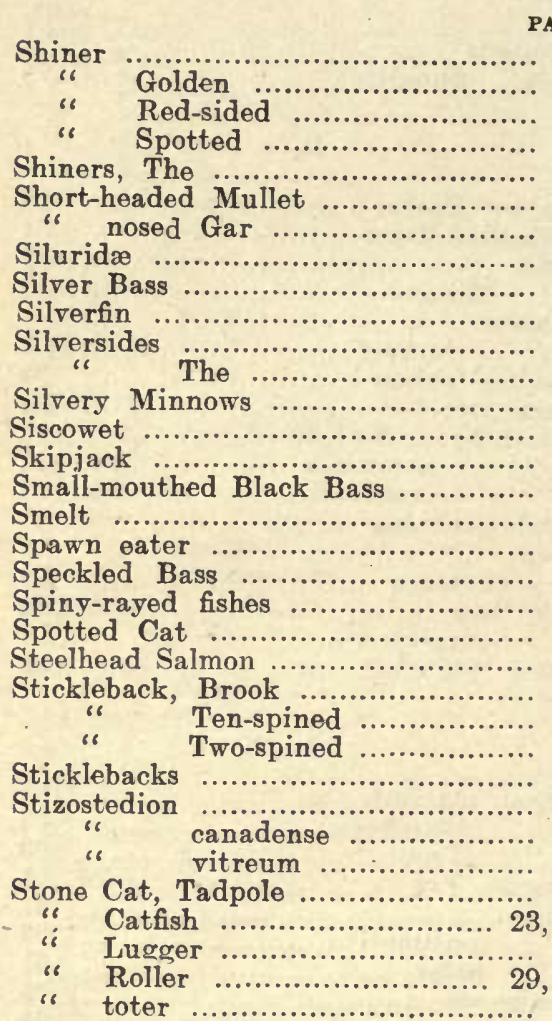

Straw-colored Minnow .................. 41

Striped Bass .............................. 99

Sturgeon, Lake ......................... 14

Rock ….................... 14

Sturgeons, The ............................ 13

Sucker, Chub ............................ 30

.

" Hog .................................. 29

" Long-nosed ......................... 28

" mouthed Buffalo ............... 26

"s Northern ............................. 28

“ Spotted ............................... 30

" Striped .................................. 31

"6 White ................................ 28

"White-nosed ......................... 31

Suckers, Carp ................................. 27

" Fine scaled ....................... 28

“ Red horse ....................... 31

"s The

Sunfish, Blue .............................. 85

" Green .............................. 85

" Yellow ............................ 86
Sunfishes,

T.

Tadpole Stone Cat ........................ 24

Teleostei ...................................... 19

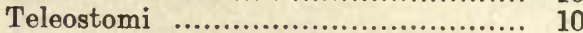

Ten-spined Stickleback .................... 73

Tessellated Darter ...................... 96

"6 Darters, The .............. 95

Togue .................................... 63

Tom, Mad ................................... 24

Triglopsis .................................. 102

" thompsoni .................. 103

Trout, Brook ............................. 64

" Gray .................................. 63

" Lake .................................... 63

" Perch ...................................... 76

" Perches, The ..................... 75, 76

“ Salmon .............................. 63

“ The ...................................... 61

Trutta ........................................... 62

Tuladi ..................................... 63

Tullibee ............................................ 60

Two-spined Stickleback ................ 74

\section{ए.}

Umbra .................................. 66

« limi .................................. 66

Umbridæ ........................................... 66

Uranidea ................................. 102

" formosa ............................ 102

franklini ....................... 102

W.

Warmouth ............................. 84

White Bass ................................... 99

" nosed Sucker .................... 31

" Sucker ............................ 28

Whitefish, Black-fin ......................... 59

"6 Common …...................... 56

" Mongrel .......................... 60

“ Round ......................... 56

" Sault .............................. 57

Whitefishes, The .......................... 56

\section{$\mathbf{X}$.}

Xenarchi

$\mathbf{Y}$

Yellow Bass .............................. 88

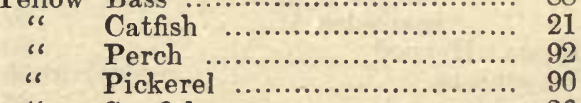

Sunfish ............................. 86 


\section{SECTION II.}

\section{BATRACHIANS AND REPTILES.}

A.

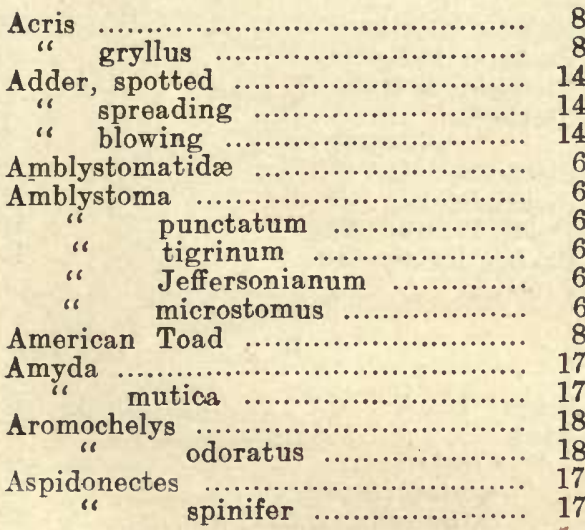

B.

Bascanion

Batrachia constrictor

Batrachians, Tailless

Black Racer "Salamander

"Snake

Blanding's Tortoise

Blowing Adder

Blue-tailed Lizard

Box Turtles

Brown Snake, Little

Bufo

" lentiginosus

Bufonidæ

Bull frog.

C.

Callopeltis ............................. 13

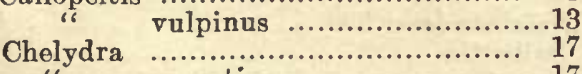
serpentina
PAGE.

Chelydridæ
Chorophilus

Chorophilus

Chrysemys

Clemmys

" insculptus ........................... 18

guttatus ...................... 18

Colubridæ ....................................... 11

Common Garter Snake ................ 12

" Rattlesnake .................... 15

" soft-shelled Turtlo ............ 17

" Tree Frog ........................ 9

Gricket Frog .................................. 8

Crotalidæ ................................ 14

Crotalus

" horridus .......................... 15

D.

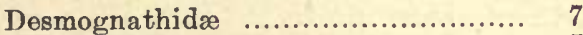

Desmognathus ............................ 7

“ fusca ........................ 7

Diadophis nigra ...................... 13

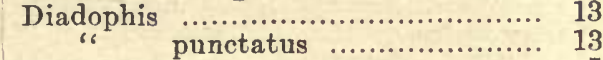

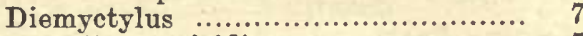

viridiscens $\ldots . \ldots \ldots \ldots \ldots \ldots . . .67$

E.

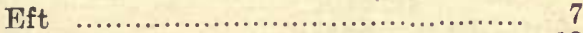

Emydidx $\ldots \ldots \ldots \ldots \ldots \ldots \ldots \ldots \ldots \ldots \ldots, 18$

Emydoidea ............................ 18

" blandingi .................... 18

Eumeces .................................. 16

8 ". anthracinus .................... 16

8 " 10 fasciatus ..................... 16

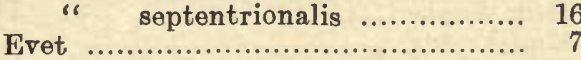

F.

Fox Snake …........................... 13

Frog, Bull ........................... 10

"i Cricket .............................. 


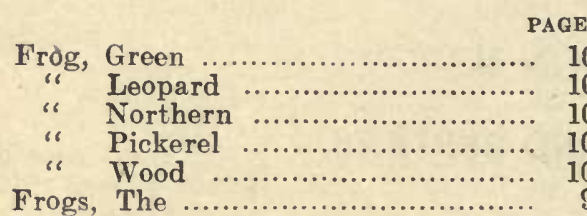

G.

Garter Snakes, The Garter Snake, Common

Glosary (Sey'

Granulated Salamander

Graptemys

Green Frog

$$
\text { geographicus }
$$

\section{H.}

Hemidactylium

Heterodon $\ldots \ldots \ldots \ldots \ldots \ldots \ldots \ldots \ldots \ldots \ldots \ldots$
" platirhinos $\ldots \ldots \ldots \ldots \ldots \ldots \ldots \ldots \ldots$

K.

Kinosternidæ

L.

Lacertilla

Lampropeltis

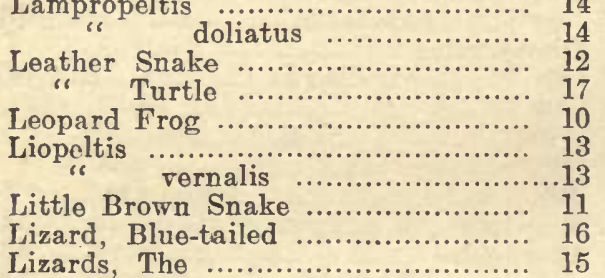

M.

Map Turtle

Milk Snake

Mud Puppy

Musk Turtle

N.

Natrix sipedon
Necturus

\section{Newt}

Northern Frog Skink

o.

Ophidia

P.

Painted Turtle 18

Pickerel Frog ........................... 10

Pickering's Hyla ........................ 9

Plethodon " cinereus

Plethodontidæ

Pond Turtes, The.

Prairie Rattlesnake ........................... 15

Proteida

R.

Racer, Black .......................... 13

Rana ..................................... 9

" areolata ........................... 9

" cantabrigensis ..................... 10

" catesbeana ............................ 10

" clamitans ................................ 10

" palustris ................................. 10

" pipiens ................................ 10

"s septentrionalis ........................ 10

"s sylvatica ................................. 10

Ranidæ .................................. 9

Rattlesnake, Common ..................... 15 " Prairie ........................ 15

Rattlesnakes. The ........................ 14

Red-backed Salamander .................. 7

Red-bellied Snake ........................ 11

Regina ..................................... 12

" leberis .............................. 12

if rigida ............................. 12

Reptiles .................................. 11

Riband Snake ........................ 12

Ring Snake .......................... 13

S.

Salamander, Black ..................... 7

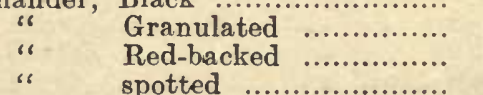

Salamanders, The .........................

Salientia .............................. 


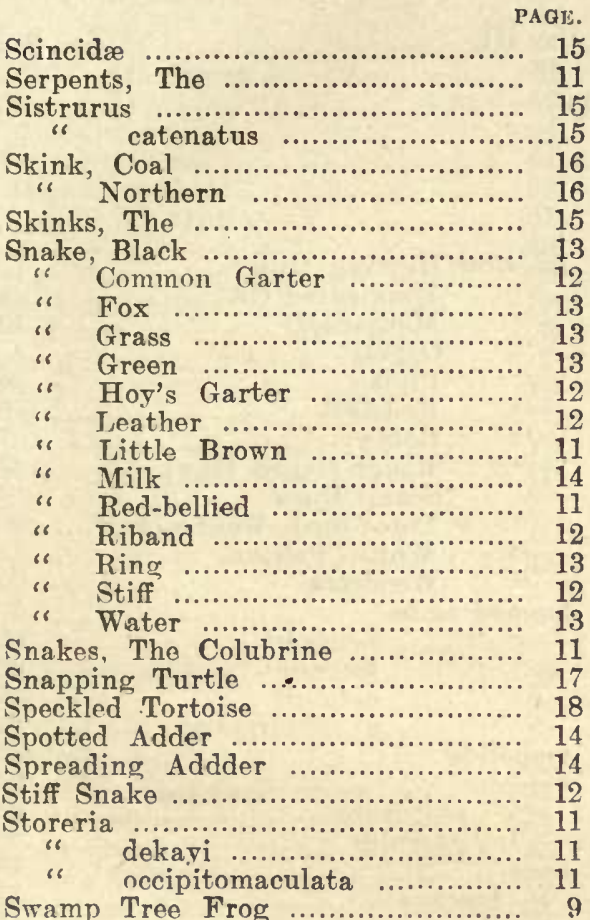

$\mathrm{T}$.

Testudinata

Thamnophis
Toad, American

Toads, The

Tortoise, Blanding's

" Speckled

"Wood

Tree Frog, Common

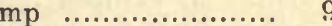

" Frogs, The ...................... 8

Trionychidæ ............................ 16

Turtle, Box ............................. 17

" Common Soft-shelled ......... 17

“ Leather .......................... 17

" Map ................................. 18

" Musk ................................ 18

" Painted .............................. 18

" Snapping ............................ 17

Turtles, The ................................. 16

"The Soft-shelled ............. 16, 17

" The Pond ........................ 18

ర.

Urodela

W.

Water Snake

Wood Frog .................................. 10

" Tortoise ........................... 18 


\section{SECTION III.}

\section{BIRDS.}

PAGE.

A.

Acadian Sharp-tailed Finch Acanthis hornemannii

h. exilipes linaria

1. holbœli

1. rostrata

Accipitrinæ

Accipiter

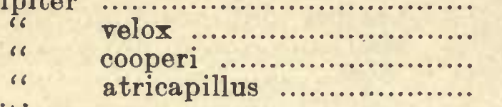

Actitis atricapillus

" macularia

Actodromas "'

maculata

fuscicollis

bairdii minutilla

Agialitis

...................................

meloda nivosa

Estrelata

hasitata

Agelaius

Aix

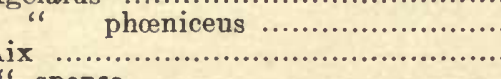

sponsa

Alaudidæ

Alca

" torda

Alcedinidæ

Alcidæ

Alcyones

Alle

" alle

American Barn Owl

Bittern

Coot

Crossbill

Egret

Eider

Golden eye

Goldfinch

Hawk Owl
62

61

61

61

61

61

61

39

40

40

40

40

31

31

28

28

28

29

29

33

33

33

33

12

12

58

58

17

17

55

9

9

48

8

48

9

9

43

22

25

60

23

19

18

61

47
American Herring Gull ................ 11

“ Long-eared Owl ............... 44

“ Merganser ...................... 14

" Osprey ............................ 43

" Pipit ............................ 76

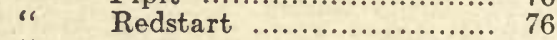

" Robin ............................. 81

“ Rough-legged Hawk ......... 41

" Scaup Duck ................... 17

" Three-toed Woodpecker..... 50

"White Pelican .............. 14

" Woodcock ......................... 27

Ammodramus ................................ 62

\begin{tabular}{|c|c|c|}
\hline & & \\
\hline & her & $\ldots$ \\
\hline & nels & \\
\hline & c & \\
\hline
\end{tabular}

Ampelidæ ................................... 68

Ampelis .................................. 68

"، cedrorum .......................... 68

Anas ........................................ 15

" boschas ................................... 15

" obscura ................................... 15

" o. rubripes .......................... 16

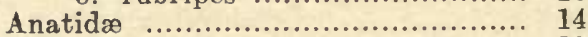

Anser ........................................... 20

" a. gambeli ............................ 20

Anthus .................................. 76

"s pennsylvanicus ................... 76

Antrostomus .............................. 52

" vociferus ................... 52

Aphrizidx ................................ 33

Arquatella ............................... 28

" maritima ................... 28

Aquila .................................... 42

Archibuteo .............................. 41

" 1. sancti-johannis .......... 41

Arctic three-toed Woodpecker ......... 49

Ardea .................................... 22

" herodias ............................... 22

Ardeidæ .................................... 21

Ardetta ................................... 22

Ardetta ..................................... 22

“ neoxena ....................... 22

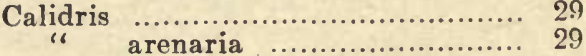


1'AGE.

Arenaria

Asio

" wilsonianus

" accipitrinus

Astragalinus

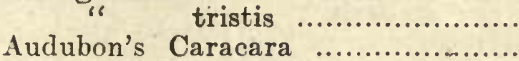

Auks, The

Auk, Razor-billed

" Aves

Avocet

Aythya

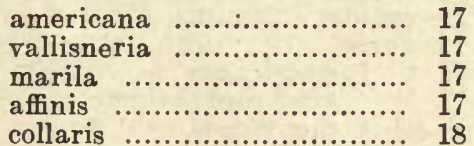

B.

Baird's Sandpiper

Baldpate

Baltimore Oriole

Bank Swallow

Barn Owl, American

$$
\text { Swallow }
$$

Barred Owl

Barrow's Golden-eye

Bartramian Sandpiper

Bartramia

longicauda

Baywing ................................ 62

Bay-brelasted Warbler

Belted Kingfisher

Bewick's Wren

Birds, The

$$
\text { " Diving }
$$

$$
\text { "6 of Prey }
$$

\section{Bitterns}

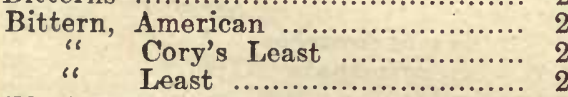

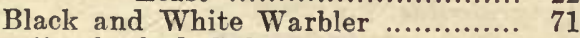

"s backed Gull ....................... 11

bellied Plover .................... 32

billed Cuckoo ...................... 48

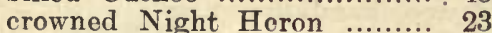

Duck ............................ 15

Guillemot ...................... 9

Poll Warbler .................... 73

Rail ................................ 25

red-legged Duck ................ 16

Scoter .................................19

Tern
" " green-Warbler ........ 73

Blackbirds, The .......................... 57

Blackbird, Yellow-headed ............. 58

"6 Red-winged .................. 58

Rusty ..................... 59

Blackburnian Warbler ............... 73

Bluebird ............................. 82

Blue-bill Duck ........................ 17

"6 "6 Little ................ 17

Blue Goose ............................. 20

" gray Gnatcatcher ............. 80

" headed Vireo .................... 70

"Heron, Great ................... 22

"، Jay ............................... 56

"s winged Teal ....................... 16

Bob White ........................... 34

Bob'o'link ................................. 57

Bohemian Waxwing ..................... 68

Bonaparte's Gull ....................... 11

Bonasa ......................................... 35

"6 umbellus ........................ 35

Botaurinæ ................................ 22

Botaurus ................................ 22

“ lentiginosus .................. 22

Brant ..................................... 21

Branta ................................... 20

" canadensis ........................ 20

"c. hutchinsii .................. 20

" bernicola ........................... 21

Broad-winged Hawk .................. 41

Bronzed Grackle ....................... 59

Brown Creeper ......................... 78

"، Thrasher ..................... 77

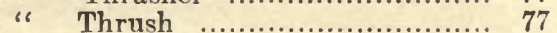

Brunnich's Murre .................... 9

Bubo .................................. 47

"6 Virginianus $\ldots \ldots \ldots \ldots \ldots \ldots \ldots \ldots, 47$

Bubonidæ .............................. 43

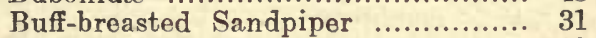

Buffle-head Duck ......................... 18

Bunting Indigo ........................ 65

"s Snow ....................... 61

Buteo .................................... 40

" borealis ........................... 40

"s lineatus ........................... 40

" platypterus ........................ 41

swainsoni

Butorides ............................. 23

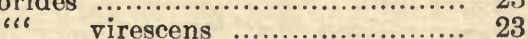

C.

Cabot's Tern .......................... 12

Calcarius ................................. 62

" lapponicus ...................... 62 


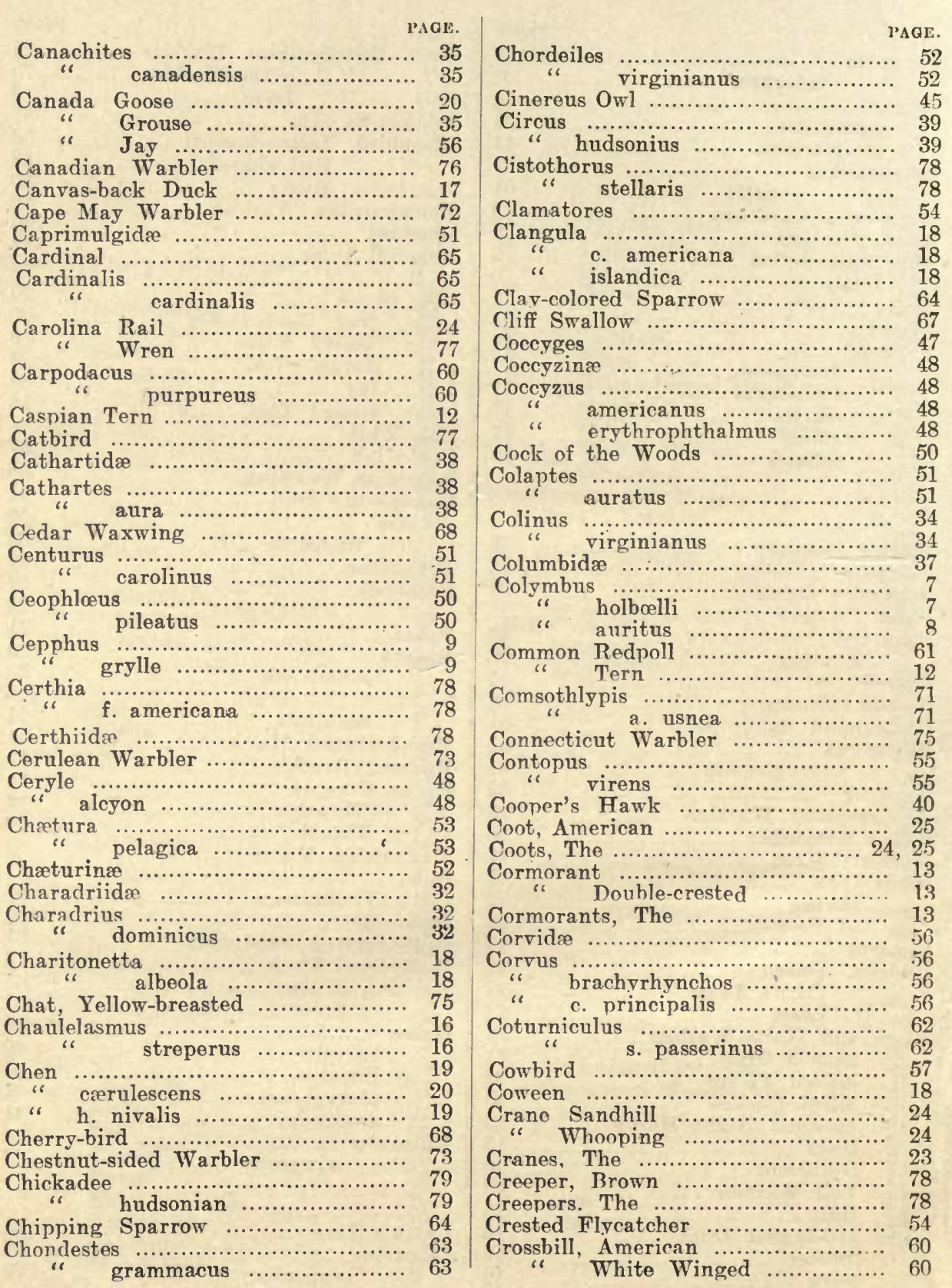




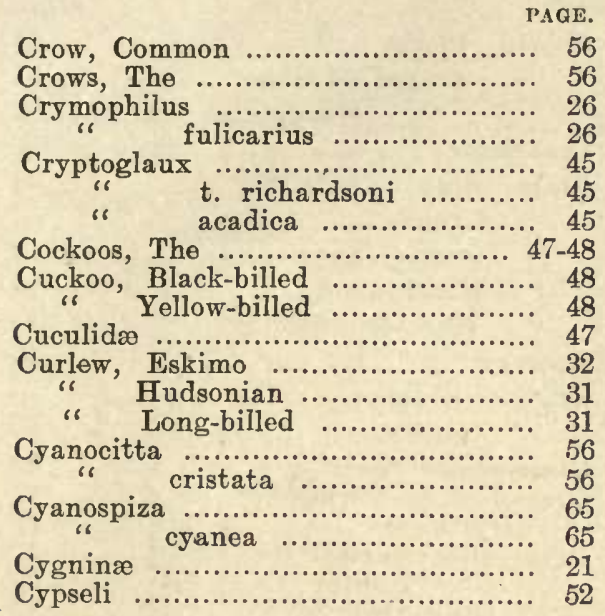

D.

Dafila

Dendroica

\begin{tabular}{|c|c|}
\hline & restiva \\
\hline & \\
\hline & \\
\hline & \\
\hline & \\
\hline & \\
\hline & \\
\hline & \\
\hline & \\
\hline & $\begin{array}{c}\text { striata } \\
\text { tigrina } \\
\ldots \ldots \ldots \ldots \ldots \ldots \ldots \ldots \ldots\end{array}$ \\
\hline & \\
\hline & \\
\hline & \\
\hline & blackburniæ.... \\
\hline & eærulescens \\
\hline & castanea ........... \\
\hline & ............ \\
\hline & ita .... \\
\hline & discolor............ \\
\hline & kirtiandos .......................... \\
\hline & palmarum \\
\hline & pennsylvanica ............ \\
\hline & (n................ \\
\hline & vigorsii .................. \\
\hline & virens. \\
\hline
\end{tabular}

Dickcissel

Diving Birds

Dolichonyx

Dovekie oryzivorous

Dove, Mourning

Dowitcher

Downy Woodpecker

Dryobates

Ducks, The

pubescens ...................... 49

villosus

Duck, American Scaup

" Black

"Canvas-back
Duck, Harlequin $\ldots \ldots \ldots \ldots \ldots \ldots \ldots \ldots . . . \ldots 18$

"، Hawk ................................ 42

" Lesser Scaup ....................... 17

" Long-tailed ........................... 18

" Redhead ................................. 17

" Red-legged Black .................. 16

" Ring-necked ......................... 18

“ Ruddy ................................. 19

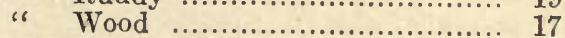

E.

Eagles, The ............................... 38

Eagle, Bald ............................... 12

" Golden ........................... 42

Ectopistes ............................. 37

“ migratorius ............... 37

Egret, American ........................ 23

Egretta ................................... 23

" candidissima .................. 23

Eider, American ......................... 19

" King ................................... 19

Elanoides ................................. 39

" forficatus ........................ 39

Empidonax .................................. 55

" flaviventris ................... 55

" minimus ........................ 55

" trailli ............................. 55

Ereunetes .............................. 29

“" pusillus ..................... 29

Erismatura ............................. i9

Eskimo, Curlew ............................ 32

Euphagus ............................... 59

“ carolinus ........................ 59

Erening Grosbeak ..................... $6 n$

\section{F.}

Falconidæ $\ldots \ldots \ldots \ldots \ldots \ldots \ldots \ldots \ldots \ldots . \ldots \ldots, 38$

Falcons, The ........................ 38, 42

Falco, columbarius ....................... 42

" islandus ................................ 42

" p. anatum .......................... 42

"6 rusticolus .......................... 42

") sparverius ........................... 42

Field Sparrow ................................ 64

Finches, The .............................. 59

Finch, Acadian Sharp-tailed ......... 62

" Pine ............................... 61

“ Purple .............................. 60

Fish Hawk ................................. 43

Flicker ..................................... 51

Florida Gallinule ........................ 25 


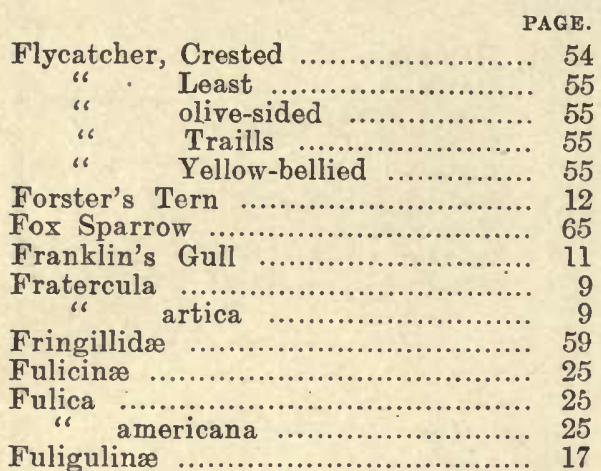

G.

Gadwall

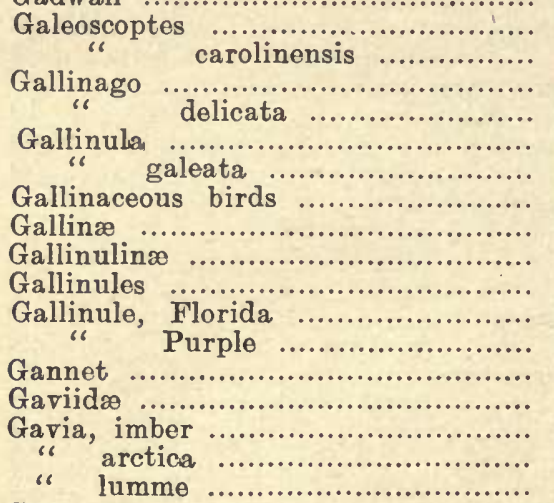

Geese, The

Geothlypis

"،

Glaucous Gul

Glossary (Sec. I.)........................ 11

Glossy Ibis ................................ 21

Gnatcatchers ....................... 79, 80

Gnatcatcher, Bluegray ................ 80

Goatsuckers ................................ 51

Godwit, Hudsonian ..................... 30

" Marbled ......................... 30

Goldfinch, American .................... 61

Golden-crowned Kinglet ................. 79

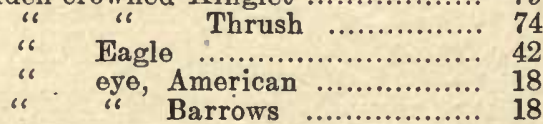

PAGE.

Golden Plover ......................... 32

" winged Warbler.............. 71

" "Woodpecker ......... 51

Goosander ............................... 14

Goose, Blue ............................. 20

" Canada ........................... 20

" Greater Snow ................... 19

" Hutchin's ....................... 20

" White-fronted .................. 20

Goshawk ................................ 40

Grackle, Bronzed ....................... 59

" Rusty .......................... 59

Grasshopper Sparrow ................... 62

Gray-cheeked Thrush ................... 81

" Gyrfalcon .............................. 42

Great Black-backed Gull .............. 11

" Blue Heron ...................... 22

“. Grey Owl .......................... 45

" Horned Owl ...................... 47

Greater Redpoll .......................... 61

" Yellow-legs ......................... 30

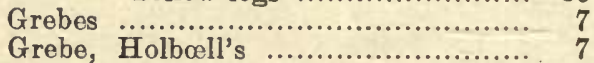

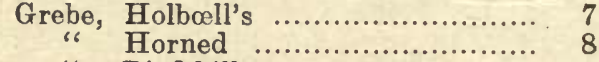

" Pied-billed ............................. 8

Green Heron .......................... 23

"6 winged Teal ....................... 16

Greenland Redpoll ........................ 61

Grosbeak, Evening ..................... 60

"، Pinening ........................ 60

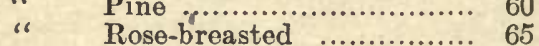

Grouse ................................ 34-35

" Canada ............................. 35

" Pinnated ............................. 35

“ Ruffed ............................. 35

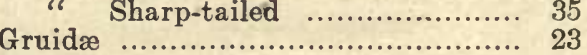

Grus ............................................ 24

"s americana ............................... 24

" mexicana .............................. 24

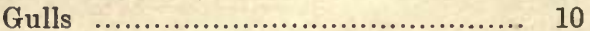

Gull, American Herring .............. 11

"Bonaparte's ........................ 11

" Franklin's ............................. 11

"Glaucous ............................ 11

"Great Black-backed ............... 11

" lceland .............................. 11

"، Ivory ..................................... 10

" Kittiwake ............................. 10

" Laughing ................................ 11

" Ring-billed ............................. 11

Gyrfalcon, Gray ........................... 42

"، White ............................ 42 
H.

Hairbird

Hairy Woodpecker ........................ 49

Haliæetus

Harelda

1. alascanus

$$
\text { hyemalis }
$$

Harlequin Duck

Hawks

Hawk, Broad-winged

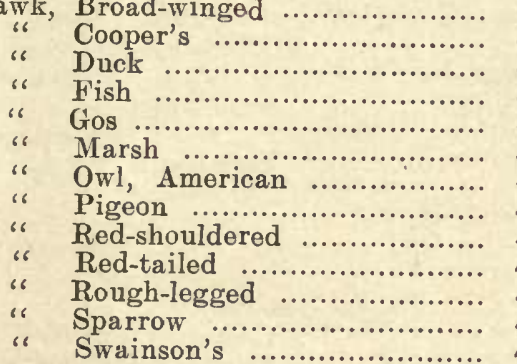

Hell Diver

Swainson's

Helminthophila

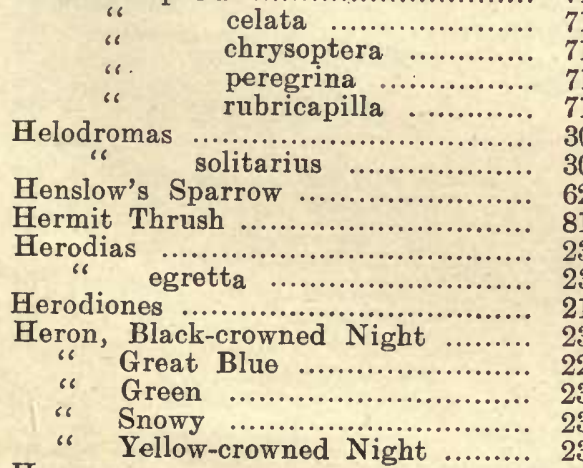

Herons ..................................... 21 $11-22$

Herring Gull, American .............. 11

Hesperiphona ................................ 60

vespertina .............. 60

High-holer ............................... 51

Hirundo ................................... 67

Hirundinidm

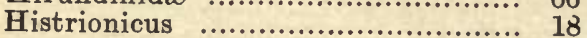

histrionicus .............. 18

Hoary Redpoll ........................... 61

Holboll's Grebe ............................... 7

" Redpoll ............................ 61

"6 Warbler .......................... 75
PAGE.

Horned Grebe ......................... 8

"، Lark ......................... 56

" Owl, Great

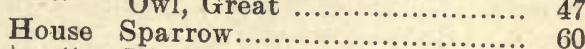

" Wren.............................. 77

Hudsonian Chickadee.................... 79

" Curlew.......................... 31

Godwit ....................... 30

Humming Birds .................. 51, 53

Humming bird, Ruby-throated ....... 53

Hutchin's Goose ........................... 20

Hydrochelidon ............................... 12

n. surinamensis ...... 12

Hylocichla ............................... 80

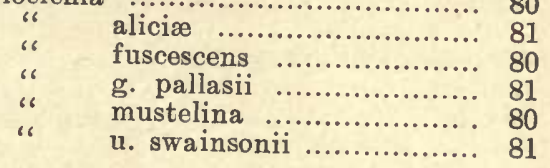

I.

Ibises .................................... 21

Ibis, Glossy ................................. 21

Iceland Gull .................................. 11

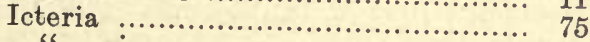

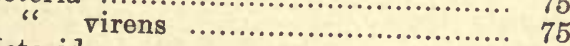

Icteridæ ....................................... 5

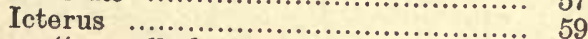

" galbula ............................... 59

"6 spurius ................................ 59

Indigo Bunting ............................ 65

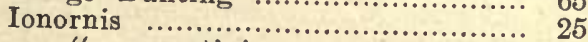

" martinica ...................... 25

Iridoprocne ................................. 67

Irory Gull bicolor …................ 67

\section{J.}

Jægers .................................... 10

Jæger, Parasitic ............................ 10

Pomarine ..................... 10

Jay, Blue ................................... 56

Canada .............. 56

Jays, The .................................... 56

Junco ....................................... 64

. "6 hyemalis ............................. 64

K.

Kentucky Warbler ...................... 75

Killdeer ....................................... 32

Kingbird .................................. 54 


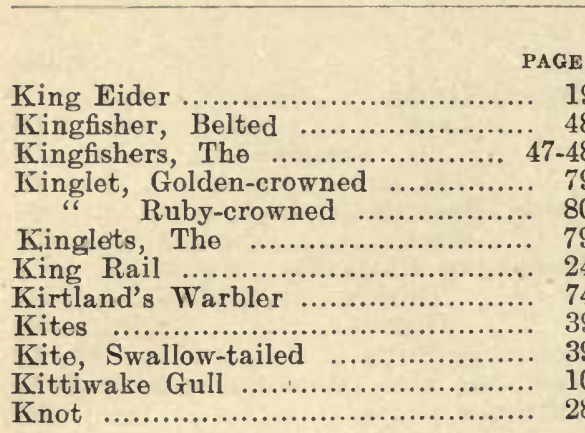

L.

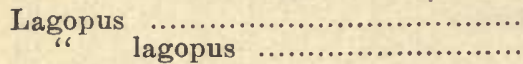

Lamellirostral Swimmers ............. 14

Laniidæ ................................... 68

Lanius ................................. 69

" borealis ........................ 69

1. migrans ......................... 69

Lapland Longspur .................... 62

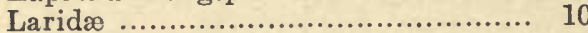

Lark, Horned ........................... 56

"6 Prairie Horned ................ 56

" Shore ............................... 56

" Sparrow .......................... 63

Larks, The ............................ 55

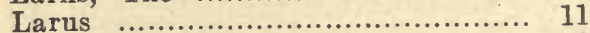

" argentatus .......................... 11

" atricilla ............................ 11

"s delawarensis ........................... 11

" franklinii ........................... 11

" glaucus

"، lucopterus ............................. 11

" marinus ............................. 11

" philadelphia ...................... 11

Laughing Gull ........................... 11

Least Flycatcher ........................ 55

" Sandpiper ....................... 29

" Tern ................................... 12

Leconte's Sparrow ..................... 62

Limicolæ .................................... 25

Limosa ..................................... 30

" fedoa .................................. 30

" hæmastica .......................... 30

Lincoln's Sparrow ...................... 64

Longipennes ............................ 9

Long-billed Curlew

" " Marsh Wren ...............

" eared Owl, American ............ 44

Longspur ................................... 62

Long-tailed Duck .......................... 18

Loon .....................................

" Black-throated

“ Red-throated

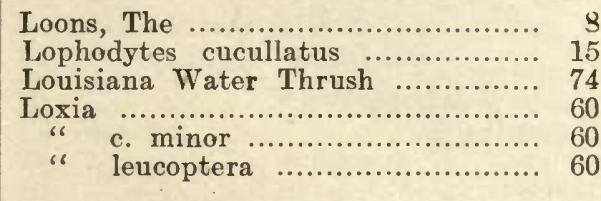

M.

Macrochires .............................. 51

Macrorhamphus ........................... 28

Magnolia Warbler

Mallard ...................................... 15

Marbled Godwit ............................. 30

Mareca ......................................... 16

"6 americana .......................... 16

Marsh Hawk ............................... 39

" Owl ............................. 44

Martin, Purple ........................... 67

" Sand .............................. 67

Maryland Warbler ...................... 75

Meadowlark .............................. 58

Megascops ............................... 46

" asio ............................. 46

Melanerpes ............................ 51

Meleagris ................................ 36

Melospiza g. silvestris .............. 36

Melospiza ...............................64

"6 c. melodia ..................... 64

" georgiana .................... 65

lincolni ..................... 64

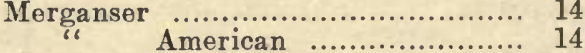

" americanus ........................ 14

" Hooded ......................... 15

" Red-breasted ................... 15

Merginæ serrator ....................... 15

Merula ...................................... 81

" migratoria ......................... 81

Micropalama ........................... 28

Micropodidx himantopus ............ 28

Migrant Shrike ............................. 69

Mimidæ ...................................... 76

Mimus ....................................... 76

" polyglottos ......................... 76

Mniotiltidæ

Mniotilta ...................................... 71

" varia ......................... 71

Mocking bird ............................ 76

Molothrus ................................... 57

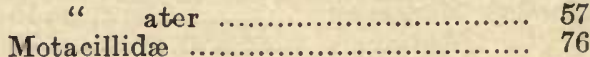


PAGL.

Mourning Dove Warbler

Murre, Brunnich's

Murres, The

Myiarchus

crinitus

Myrtle Warbler

N.

Nashville Warbler

Nelson's Sparrow

Nettion

" ca

Northern

rolinensis

"

Shrike

Numenius

borealis

" hudsonicus

longirostris

Nuthatch, Red-breasted

White-breasted

Nuthatches, The

Nuttallornis

Nyctanassa

borealis

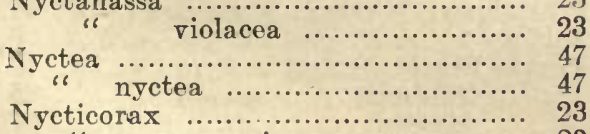

n. nævius .................. 23

o.

Oidemia

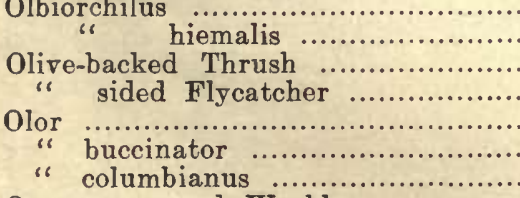

Orange-crowned Warbler

Oriole, Baltimore

"Orchard

Orioles, The

Osprey, American

Otocoris

" alpestris

"a. praticola

Oven bird

37

75

9

8

54

54

73

71

62

16

16

52

26

56

69

31

32

31

31

79

79

79

55

55

23

47

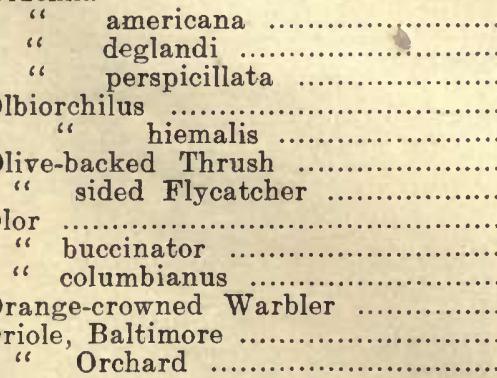

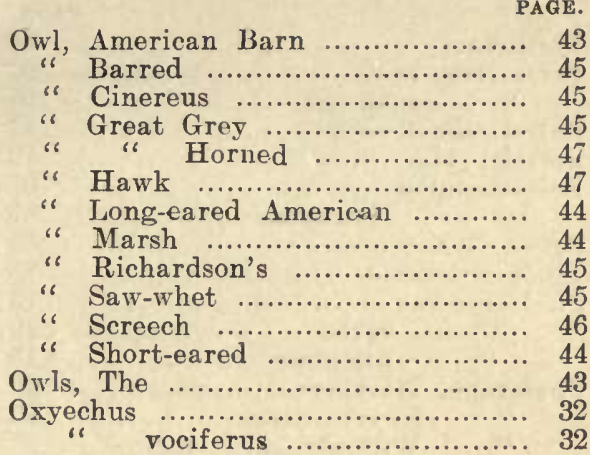

P.

Pagophila .............................. 10

alba .......................... 10

Palm Warbler ............................ 74

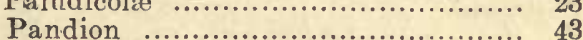

" h. carolinensis .............. 43

Pandioninæ ................................. 43

Parasitic Jæger ......................... 10

Paridæ ................................... 78

Partridge ..................................... 35

"spruce ......................... 35

Parula Warbler ........................... 71

Parus ...................................... 79

" atricapillus .......................... 79

" hudsonicus ....................... 79

Passer domesticus ......................... 60

Passenger Pigeon ........................... 37

Passerculus ............................ 62

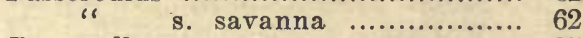

Passerella ................................ 65

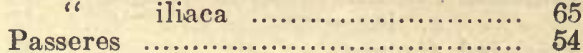

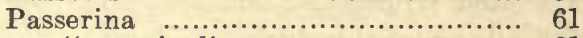

nivalis ....................... 61

Pavoncella ............................... 31

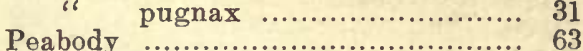

Pectoral Sandpiper ....................... 28

Pediocetes ..................................... 35

phasianellus ................ 35

Pelecanidæ ............................... 14

Pelecanus .................................. 14

" "s erythrorhynchos ............. 14

Pelican, American White .............. 14

Pelicans, The .............................. 14

Pelidna ................................ 29

"s a. sakhalina ................... 29 


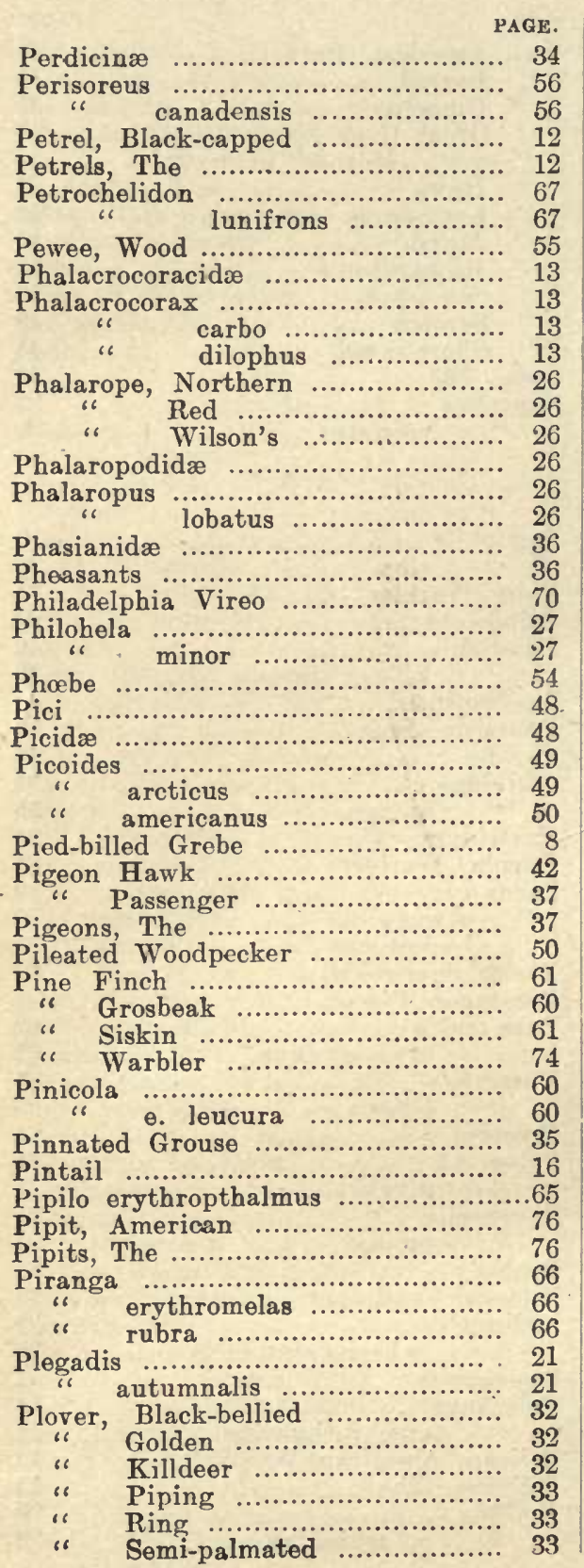

Plover, Snowy PAGE.

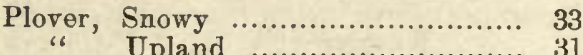

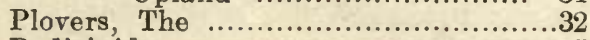

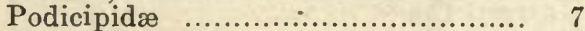

Podilymbus ............................... 8

"6 podiceps ..................... 8

Polioptila ............................. 80

Porulea ...................... 80

Polyborus .................................. 43

Pomarine cheriway ......................... 43

Poecetes .................................. 62

" gramineus ..................... 62

Porzana ................................... 24

" carolina .............................. 24

" jamaicensis ...................... 25

" noveboracensis ................ 25

Prairie Chicken ........................... 35

" Hen ............................... 35

“ Horned Lark ................... 56

" Warbler ........................ 74

Procelllariidæ ............................ 12

Progne ..................................... 67

" subis ............................ 67

Protonotaria ............................ 71

“" citrea ........................ 71

Prothonotary Warbler ................. 71

Ptarmigan, Willow ..................... 35

Puffin ...................................... 9

Purple Finch .............................. 60

" Gallinule ........................... 25

" Martin .............................. 67

" Sandpiper ......................... 28

Pygopodes ............................... 7

Q.

Quail ...................................... 34

Querquedula ........................... 16

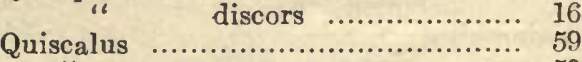

" q. aeneus ...................... 59

R.

Rail Black ............................... 25

"s Carolina .................................. 24

“ King ................................. 24

"Virginia .............................. 24

"، Yellow ....................................... 25

Rails, The ............................23, 24

Rallus ........................................... 24

"s elegans ............................. 24

" virginianus .......................... 24

Raptores …................................... 38

Raven, Northern ..................... 56 
PAGE.

Razor-billed Auk

Recurvirostra

Recurvirostridæ

Red-backed Sandpiper ............... 29

Red-bellied Woodpecker ............... 51

Red-breasted Nuthatch ................ 79

Red-eyed Vireo ............................. 69

Redhead Duck ......................... 17

Red-headed Woodpecker ............. 5]

Red-legged Black Duck .............. 16

Red Phalarope .......................... 26

Redpoll, Common ....................... 61

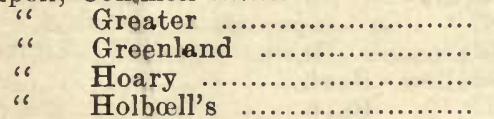

Redshank

Red-shouldered Hawk ........... ..... 40

Redstart, American .................... 76

Red-tailed Hawk ........................ 40

"s throated Loon ...................... 8

" winged Blackbird ................. 58

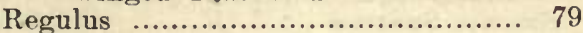

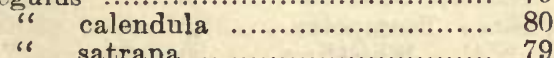

Richardson's Owl ......................... 45

Ring-billed Gull ....................... 11

" necked Duck ..................... 18

"6 Plover ............................... 33

Riparia ................................ 67

riparia $\ldots \ldots \ldots \ldots \ldots \ldots \ldots \ldots, 67$

" tridactyla........................... 10

River Ducks, The ..................... 15

Robin, American ....................... 81

Rose-breasted Grosbeak ................. 65

Rough-winged Swallow ................ 68

Ruby-crowned Kinglet ................ 80

" throated Humming bird ...... 5.3

Ruddy Duck ............................ 19

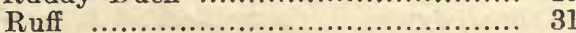

Rusty Blackbirìd ........................ 59

"6 Grackle ........................... 59

S.

Sanderling

Sandhill Crane

Sandpiper,

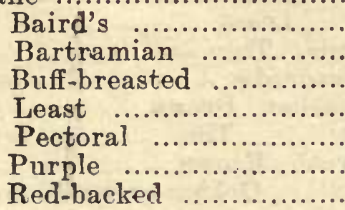

Sand piper,
66
66
66

Sandpipers

Sapsucker

Savanna Sparrow

Saw-whet Owl

Sayorins

Saxicola

phobe

Scarlet Tanager

Semi-palmated

PAGE.

Spotted ................. 31

Stilt .................... 28

White-rumped ........... 28

Scolopacidæ ............................. 26

Scoter, American ....................... 19

" Black ............................... 19

"6 Surf ............................ 19

" White-winged ................... 19

Scotiaptex ............................. 45

"6 nebulosa ..................... 45

Seiurus ................................. 74

" aurocapilllus .................. 74

" motacilla ......................... 74

" noveboracensis ................ 74

Semi-palmated Plover ................ 33

Setophaga ............................... 76

"6 ruticilla $\ldots . . . \ldots \ldots \ldots \ldots \ldots \ldots, 76$

Sharp-shinned Hawk .................. 40

" tailed Finch, Acadian ........ 62

Grouse .................. 35

Shore Lark .......................... 56

Short-billed Marsh Wren .............. 78

"s eared Owl ...................... 44

Shoveller Duck ............................ 16

Shrike, Migrant ..................... 69

" Northern ....................... 69

Shrikes, The ............................ 68

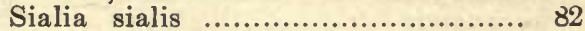

Siskin, Pine ............................. 61

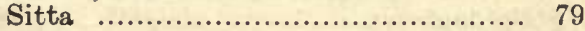

" canadensis .......................... 79

"6 carolinensis ....................... 79

Sittidæ ................................. 79

Snipes, The ............................ 26

Snipe, Wilson's ....................... 27

Snow bird ............................... 61

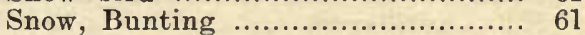

"Goose, Greater ................. 19

Snowy Heron ........................... 23

" Owl .............................. 47

" Plover ........................... 33

Solitary Sandpiper .................... $\quad 30$

Vireo $\ldots \ldots \ldots \ldots \ldots \ldots \ldots \ldots, 70$ 
PAGE.

Thrush, Gray-cheeked

Hermit

Olive-backed

Water

Wilson's

Wood

Thryomanes

es

Thryothorus bewickii

Tits, The

Totanus "6

melanoleucus

Totlipalmate Swimmers

Towhee

Toxostoma

$$
\text { rufum. }
$$

Traill's Flycatcher

Tree Sparrow

" Swallow

Tringa

Trochilidæ

Trochilus

$$
\text { "، }
$$

Troglodytes

$$
\text { colubris }
$$

Troglodytidre aedon

Trumpeter Swan

Tryngites

Turdide subruficollis

Turkeys, The

Turkey, Vulture

$$
\text { " Wild }
$$

Turnstone

Turnstones, The

Tympanuchus

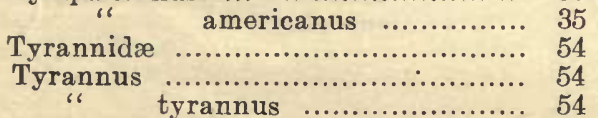

Tyrant Flycatchers

\section{U.}

Upland Plover

Uria "lomvia

\section{V.}

Vesper Sparrow

Vireo

Blue-headed
81

81

81

74

80

80

77

77

77

77

78, 79

30

30

30

13

65

77

77

55

64

67

28

28

53

53

53

77

77

76

21

31

31

80

36

38

36

33

33

35 54

31

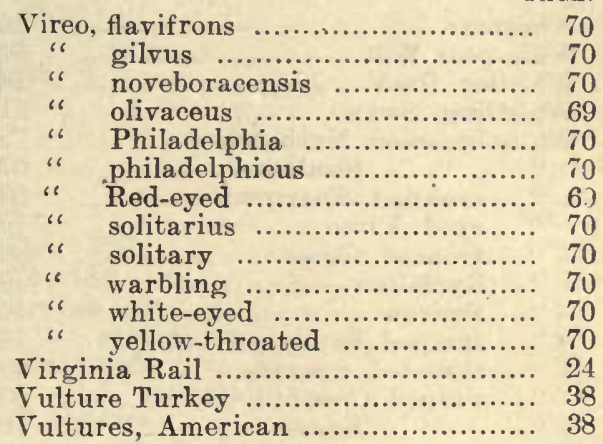

W.

Warbler, Bay-breasted ................ 73

" Black and White ........... 71

" Blackburnian ................ 73

" $\quad$ Blackpoll ......................... 73

" Black-throated Blue ........ 72

" Black-throated Green …. 73

" Canadian ....................... 76

" Cape May ................... 72

" Cerulean.

" Chestnut-sided ............... 73

" Connecticut .................... 75

" Golden-winged ................ 71

" Hooded ......................... 75

" Kentrcky

" Kirtland's .................... 74

" Magnolia ....................... 73

" - Maryland ........................... 75

" Mourning ........................ 75

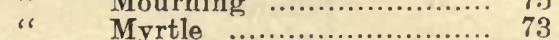

" Nashville ........................ 71

" Orange-crowned ............... 71

" Palm .............................. 74

" Parula ............................ 71

، Pine ……................. 74

" $\quad$ Prairie .............................. 74

" $\quad$ Prothonotary ................. 71

" Tennessee .......................... 71

" Wilson's ........................... 75

" Yellow ................................ 72

is Yellow-rumped ................. 73

Warblers, The ........................... 70

Warbling Vireo ................................. 70

Water Thrush ......................... 74

"s "

Wavey ..................................... 19

Waxwing, Bohemian ................... 68

" Cedar .......................... 68

Waxwing, The ............................. 68 
PAGE.

Wheatear

Whip-poor Will

Whistler Duck

Whistling Swan

White-breasted Nuthatch

"6 "6 Swallox

crowned Sparrow

eyed Vireo

fronted Goose

Gyrfalcon ....................... 42

Pelican .......................... 14

rumped Sandpiper .............. 28

throated Sparrow ............... 63

winged Crossbill ................. 60

" 6 Scoter ....................... 19

Whooping Crane .......................... 24

Wild Turkey .............................. 36

Willet ................................... 30

Willow Ptarmigan ...................... 35

Wilsonia .............................. 75

" canadensis .................... 76

" mitrata ........................ 75

« pusilla ........................ 75

Wilson's Phalarope .................... 26

" Snipe ......................... 27

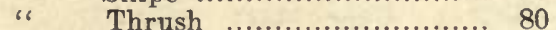

" Warbler ....................... 75

Winter Wren .......................... 77

Woodcock ................................. 27

Wood Duck .......................... 17

Woodpecker, Am. three-toed ........ 50

Arctic ................... 49

Downy .................. 49

Golden-winged ......... 51

Hairy .................... 49

Pileated .................. 50

Red-bellied .............. 51

Red-headed .............. 51

Yellow-bellied ........... 50

Woodpeckers, The

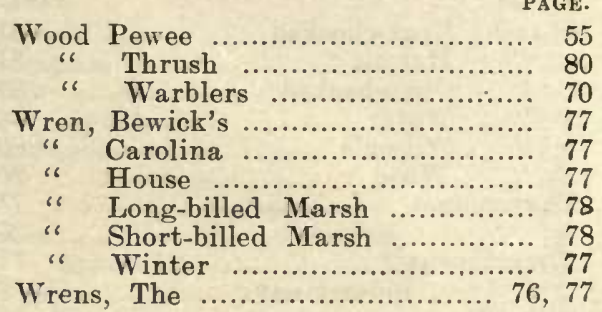

X.

Xanthocephalus ...................... 58 xanthocephalus ....... 58

$\mathbf{Y}$.

Jellow-bellied Woodpecker ........... 50

"6 "6 Flycatcher ............. 48

" billed Cuckoo ................... 48

" breasted Chat .................. 75

" crowned Night Heron ......... 23

" headed Blackbird ................ 58

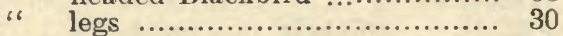

"6 6 Greater ................... 30

" Rail ............................... 25

" throated Vireo ................... 70

" Warbler ....................... 72

\section{Z.}

Zamelodia ............................. 65

" ludoviciana ................. 65

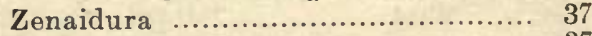

"6 macroura ................ 37

Zonotrichia .......................... 63

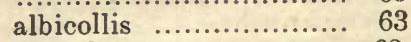

leucophrys ............... 63 


\section{SECTION IV.}

\section{MAMMALS.}

A.

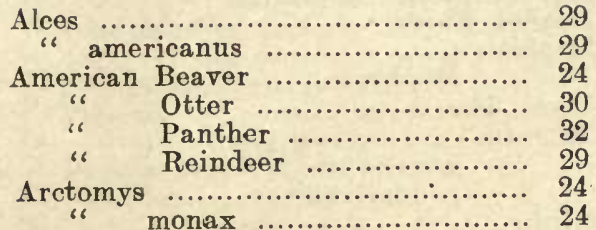

B.

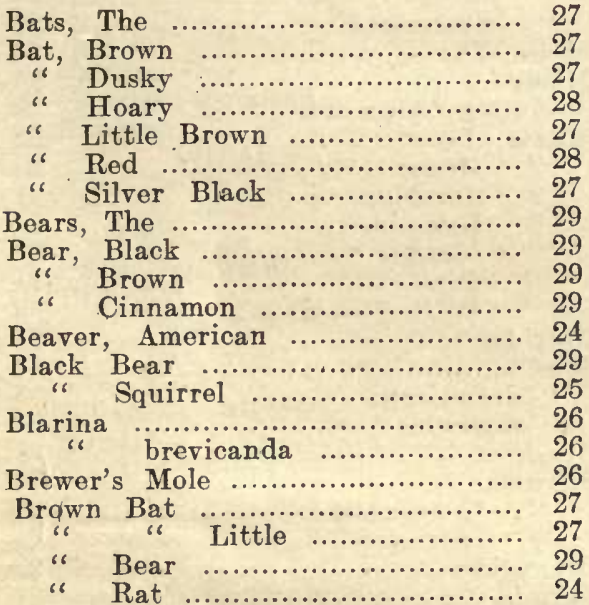

C.

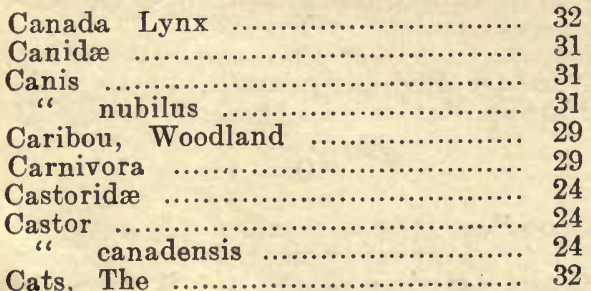

PAGE.

Cat, Wild ............................. 32

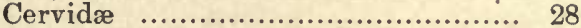

Cervus ....................................... 28

" canadensis ........................ 28

Chipmunk ............................. 24

" mountain ..................... 24

Chiroptera ................................ 27

Cinnamon Bear ......................... 29

Common Flying Squirrel ............. 25

" House Mouse ............... 24

" Raccoon ........................... 29

" Skunk .......................... 30

Condylura .................................. 26

“ cristata ....................... 26

Cotton-tail ................................ 19

Cougar........................................... 32

D.

Deer Mouse ............................. 23

" Red $\ldots$

" The ............................. 28

“ Virginia ............................... 28

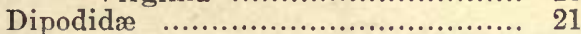

Dogs, The .............................. 31

Dusky Bat ............................... 27

E.

Elk .................................. 28

" True .................................. 29

Erethizon .............................. 20

". dorsalis ............................ 20

Erethizontidæ ............................. 20

Ermine .......................................... 31

Eutamias ......................... 24

" quadrivittatus ................. 24

Evotomys ............................. 23 " gapperi .......................... 23

\section{F}

Felidæ ...................................... 32

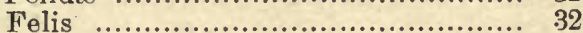

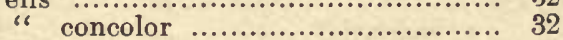

Feræ ...................................... 29

Fiber zibethicus ........................... 21 


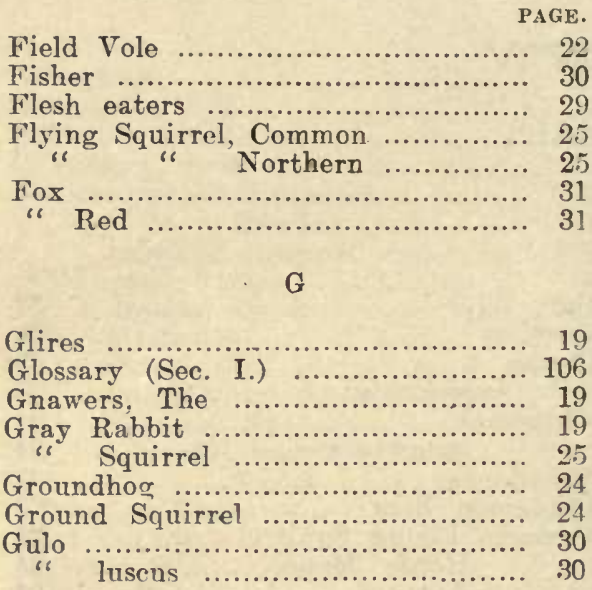

\section{$\mathrm{H}$}

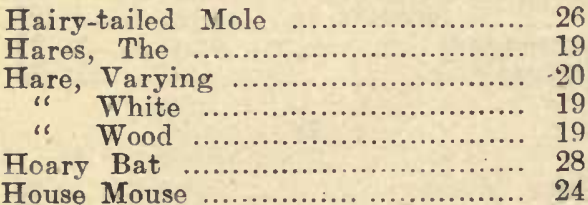

I.

Insect eaters, The

Insectivora

\section{$\mathbf{J}$}

Jumping Mouse

L.

Lasionycteris

Lasiurus

$$
\text { noctivagans }
$$

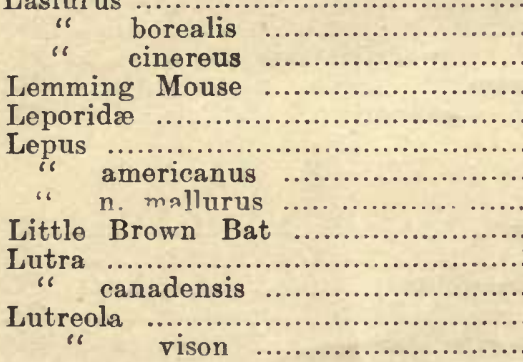

Muskrat

Mustela

" americana ......................... 30

" pennantii ...................... 30

Mustelidæ ................................... 29

Myotis ................................ 27

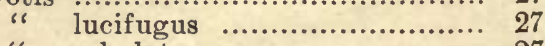

"s subulatus .......................... 27

N.

Northern Flying Squirrel .............. 25

Norway Rat .............................. 24

0.

Odocoilus ................................. 28

" americanus .................... 28

Otter, American ........................... 30 
PAGE.

\section{P.}

Panther, American

Parascalops

Pekan

breweri

Peromyscus

"6 leucopus ...................... 23

Phenacomys .............................. 23 " latimanus ................... 23

Pine Martin ............................. 30

" Mouse .............................. 21

Porcupine, Canada ...................... 20

Procyon ....................................... 29

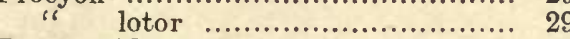

Procyomidæ ................................ 29

Putorius .................................. 31

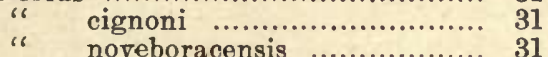

R.

Rabbit, Gray

Raccoon, Common ..................... 29

Rangifer ............................... 29

Rat, Brown caribou ........................ 29

" Musk ............................. 24

" Norway ........................... 24

Red-backed Vole .......................... 23

Red Bat .................................... 28

" Deer ............................... 28

" Fox ............................... 31

" Squirrel ........................... 25

Reindeer, American .................. 29

Rodents

S.

Sable

Soiuronterus

Sciuropterus
،

Sciurus carolinensis hudsonicus

Sciuridæo

Shrow, Masked "Mole

"Sooty

Shrews, The

Silver black Bat

Skunk, Common

Small Brown Weasel

Sooty Shrew
32

26.

30

3

3

30

\section{S}

Star-nosed Mole ...................... 26

Stoat .................................. 31

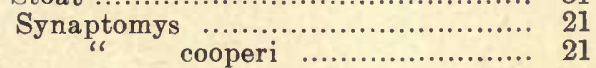

T.

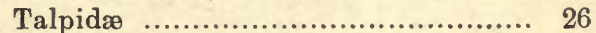

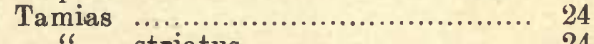

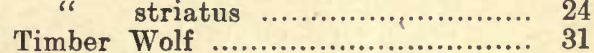

True Elk ............................ 29

U.

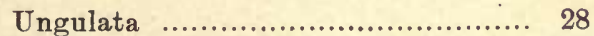

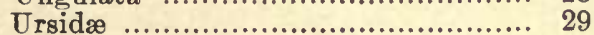

Ursus .................................... 29

"6 americanus ...................... 29

$\nabla$.

Vespertilio ............................. 27

" fuscus ........................ 27

Vespertilionidær......................... 27

Virginia Deer ............................ 28

Vole, Field .............................. 22

" Red-backed ........................ 22

Vulpes pennsylvanicus ................. 31

\section{W.}

Wapiti $\ldots \ldots \ldots \ldots \ldots \ldots \ldots \ldots \ldots \ldots \ldots \ldots, 28$

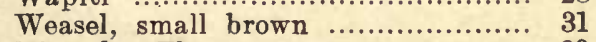

Weasels, The ........................... 29

White-footed Mouse .................... 23

Wild Cat .................................. 32

Wolf .................................... 31

Wilverene ................................ 30

Woodchuck ............................... 24

Woodland Caribou ...................... 29

Z.

Zapus $\ldots \ldots \ldots \ldots \ldots \ldots \ldots \ldots \ldots \ldots \ldots \ldots \ldots \ldots \ldots \ldots \ldots, 21$ 




THIS BOOK IS DUE ON THE LAST DATE STAMPED BELOW

AN INITIAL FINE OF 25 CENTS WILL BE ASSESSED FOR FAILURE TO RETURN THIS BOOK ON THE DATE DUE. THE PENALTY WILL INCREASE TO 50 CENTS ON THE FOURTH DAY AND TO \$1.00 ON THE SEVENTH DAY OVERDUE.

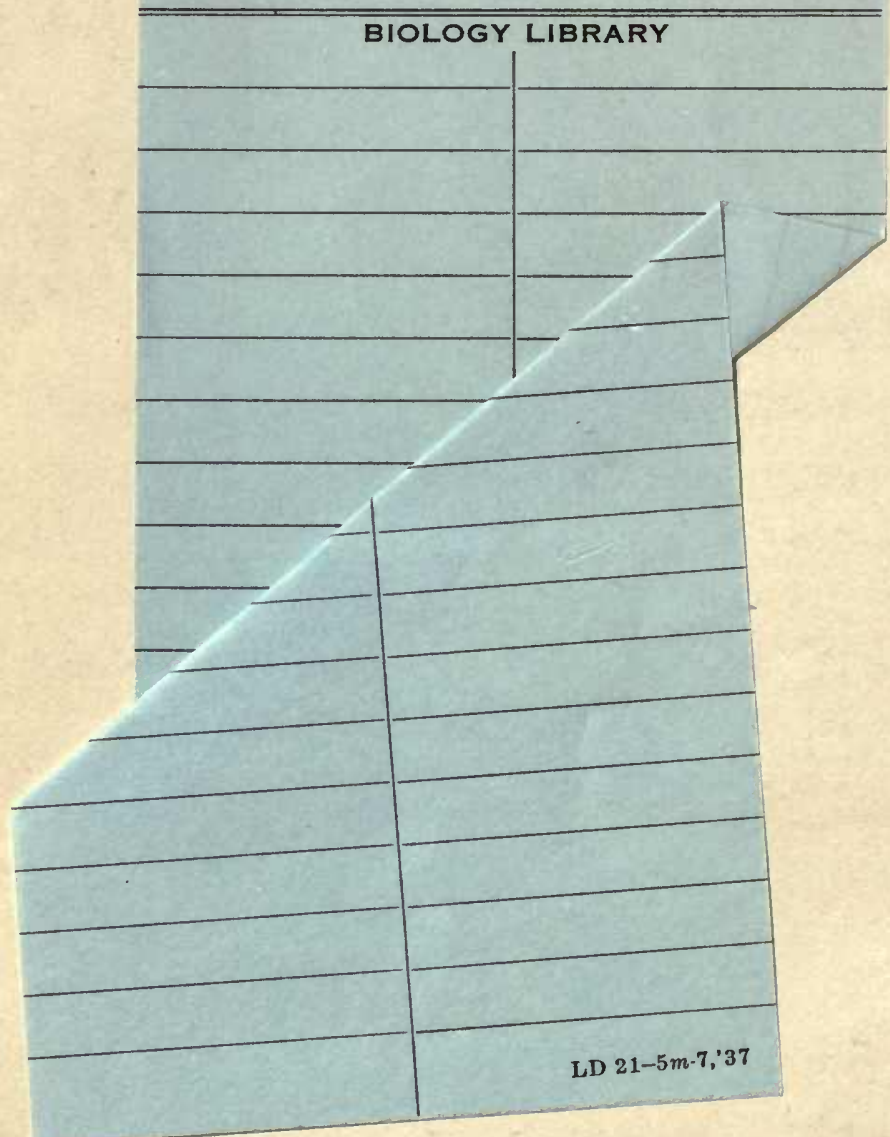


